\title{
Functional Equivalency of Created and Natural Wetlands in the Central Appalachians: Reproductive Success, Call Phenology, and Diet Composition of Amphibians
}

\author{
Gabriel F. Strain \\ West Virginia University
}

Follow this and additional works at: https://researchrepository.wvu.edu/etd

\section{Recommended Citation}

Strain, Gabriel F., "Functional Equivalency of Created and Natural Wetlands in the Central Appalachians: Reproductive Success, Call Phenology, and Diet Composition of Amphibians" (2014). Graduate Theses, Dissertations, and Problem Reports. 630.

https://researchrepository.wvu.edu/etd/630

This Dissertation is protected by copyright and/or related rights. It has been brought to you by the The Research Repository @ WVU with permission from the rights-holder(s). You are free to use this Dissertation in any way that is permitted by the copyright and related rights legislation that applies to your use. For other uses you must obtain permission from the rights-holder(s) directly, unless additional rights are indicated by a Creative Commons license in the record and/ or on the work itself. This Dissertation has been accepted for inclusion in WVU Graduate Theses, Dissertations, and Problem Reports collection by an authorized administrator of The Research Repository @ WVU.

For more information, please contact researchrepository@mail.wvu.edu. 
Functional Equivalency of Created and Natural Wetlands in the Central Appalachians:

Reproductive Success, Call Phenology, and Diet Composition of Amphibians

Gabriel F. Strain

Dissertation submitted to the

Davis College of Agriculture, Natural Resources, and Design

at West Virginia University

in partial fulfillment of the requirements

for the degree of

Doctor of Philosophy

in

Forest Resources Science

James T. Anderson, Ph.D., Chair

Petra Bohall Wood, Ph.D.

Philip J. Turk, Ph.D.

Thomas K. Pauley, Ph.D.

Kevin Dodge, M.S.

Division of Forestry and Natural Resources

Morgantown, West Virginia

2014

Keywords: Anurans, Compensatory mitigation, Habitat, Macroinvertebrates, Metamorphs, Predator-prey, Salamanders, Wetland function, Wetland loss, Wildlife 


\begin{abstract}
Functional Equivalency of Created and Natural Wetlands in the Central Appalachians: Reproductive Success, Call Phenology, and Diet Composition of Amphibians.
\end{abstract}

\title{
Gabriel F. Strain
}

Evaluating the adequacy of created wetlands to replace the functions of lost natural wetlands is important because wetland mitigation is a major tool used to offset wetland losses. However, measurements such as vegetative cover and presence of wildlife may not provide sufficient evidence that created wetlands are functioning properly and thus examining the ecology of wetland biota such as that of amphibians may be a more useful surrogate for function. The objectives of this study were to assess the reproductive success, temporal calling patterns, and diet composition of amphibians inhabiting created wetlands relative to natural wetlands in order to facilitate determination of the adequacy of created wetlands as functional replacements of natural wetlands.

To evaluate reproductive success, I compared the abundance of amphibian metamorphs and survival and growth of larval amphibians in created wetlands relative to natural wetlands. Amphibian metamorphs were trapped in created and natural wetlands during the spring and summer of 2009 and 2010, and 165 green frog (Lithobates clamitans) larvae were raised during the spring of 2010 in laboratory aquaria containing water from created or natural wetlands. Abundance of spring peeper (Pseudacris crucifer) metamorphs decreased significantly from 2009 to 2010 and abundance of green frog metamorphs increased with habitat complexity, but both were unaffected by wetland type. Detection probability of metamorphs of both species was very low, increased with water temperature, and declined with month of observation. Survival, growth curves, and mass were similar between green frog larvae raised in created and natural wetland aquaria. My results suggest that the function of providing adequate breeding habitat for generalist amphibians such as green frogs and spring peepers is being fulfilled by the created wetlands that were examined.

I compared the occupancy and detection of calling anurans in created wetlands relative to natural wetlands to assess temporal calling patterns. Five-minute, ten-minute, and broadcast call surveys were performed at 24 wetlands throughout the Central Appalachians once every month from March through August of 2009 and 2010. Occupancy modeling was used to estimate the occupancy and detection of individual species, incorporating relevant environmental variables. The occupancy of anurans did not differ between created and natural wetlands. Detection of anurans was largely unaffected by call survey type, but several environmental covariates had a significant effect on the detectability of calling anurans. I conclude that the function of providing adequate breeding habitat for adult anurans is being fulfilled by the created wetlands that were examined.

To assess the diet composition of amphibians, I measured the diet composition of adult red-spotted newts (Notophthalmus viridescens viridescens) and compared the selection of prey by newts between created and natural wetlands. Newts were trapped during the spring and summer of 2009 and 2010, and the stomach contents of 149 newts were obtained with gastric lavage. Invertebrate prey availability was obtained within a $5 \mathrm{~m}$ radius of each captured newt. 
Selection of prey by newts was nonrandom, but was only minimally affected by wetland type. Both dietary breadth and prey selection were affected primarily by time of year, likely driven by temporal variation in invertebrate abundance. My results suggest that the function of providing an adequate prey base for a generalist wetland predator such as the red-spotted newt is being fulfilled for the created wetlands that were examined. 


\section{ACKNOWLEDGMENTS}

This research was funded by the West Virginia University Division of Forestry and Natural Resources through the McIntire-Stennis program, the West Virginia Division of Highways, the WVU Environmental Research Center, the National Oceanic and Atmospheric Administration, the WVU Arlen G. and Louise Stone Swiger Doctoral Fellowship, and a student research grant from the South Atlantic Chapter of the Society of Wetland Scientists. I thank the Canaan Valley National Wildlife Refuge, Mt. Storm Power Station, The Nature Conservancy, and Potomac-Garrett State Forest for allowing me to use wetlands under their respective care.

I thank my advisor, Jim Anderson, for giving me the opportunity to work on this project. He always gave me just the right amount guidance and autonomy to help me grow as a scientist, as well as countless opportunities to improve my skills and add to my resume. Thank you to Petra Bohall Wood for the support and patience throughout my long trip as a PhD student, and for the very insightful comments on every draft of every chapter. I thank Phil Turk for his very hard work assisting me with the statistics for this project, and for the many dinners at Eat ' $\mathrm{N}$ Park, where we discussed a plethora of topics beyond academia and statistics. Thank you to Thomas K. Pauley for his bottomless knowledge of everything herp-related: from experimental design to field identification, he was a great source of wisdom and support. Sincere appreciation to Kevin Dodge, not only for helping me locate wetlands and other resources, but for the meetings and lunches which helped me see the Mixed Appalachian Forest for the trees.

I had numerous volunteers and technicians without which this experience would have been miserable. Alison Anderson and GeriAnn Albers helped me collect and process green frog tadpoles. Donna Hartman assisted me in keeping the laboratory experiment running smoothly. 
Eric Miller, Brian Olejasz, Aaron Nemeyer, and Noah McCoard spent long nights driving through West Virginia and listening to frogs call with me. Tristan Gingerich, Eric Miller, Jon Pitchford, Aaron Nemeyer, Brian Olejasz, and Noah McCoard helped me trap newts and invertebrates and pump newt stomachs. Donna Hartman and Eric Merriam donated large portions of their time to help me identify invertebrates. Thank you to fellow graduate students Ross Andrew, Tristan Gingerich, Daniel Hanks, Holly McChesney, Eric Miller, and Jon Pitchford for moral support. 


\section{TABLE OF CONTENTS}

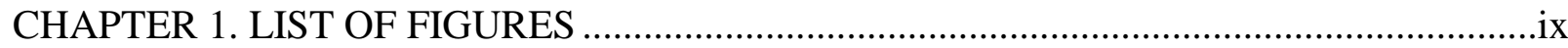

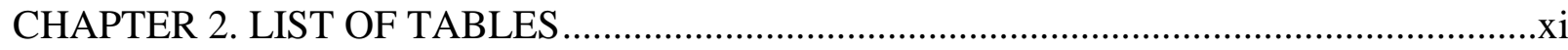

CHAPTER 2. LIST OF FIGURES …......................................................................... xii

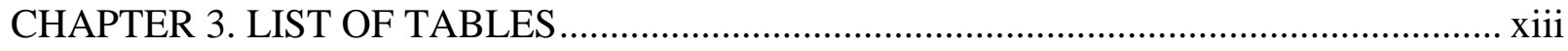

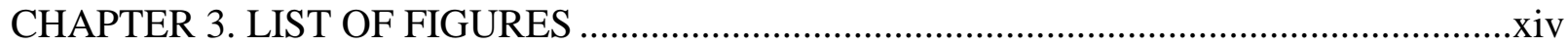

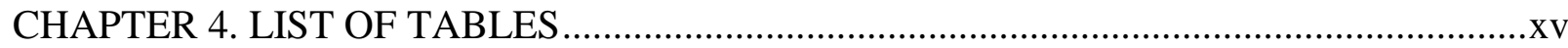

CHAPTER 4. LIST OF FIGURES …......................................................................

CHAPTER 1 .................................................................................................................................................1

The significance of wetlands and wetland amphibians and the role of compensatory

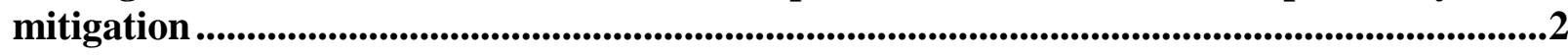

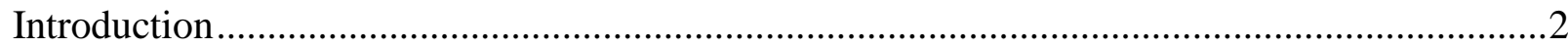

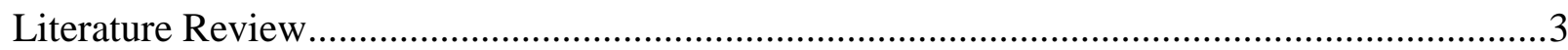

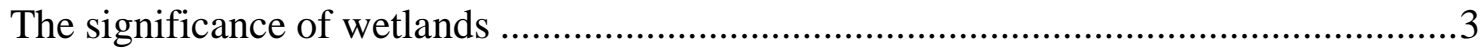

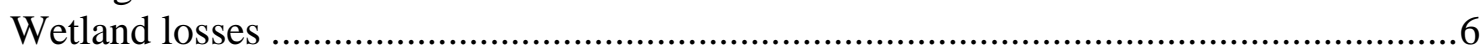

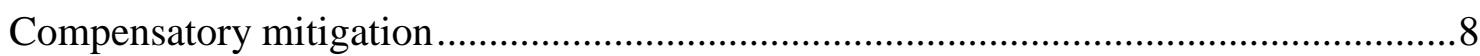

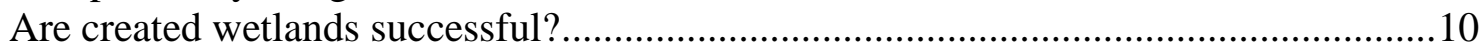

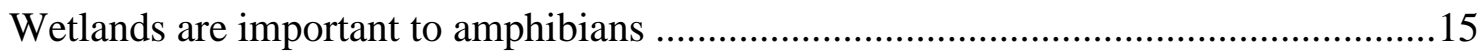

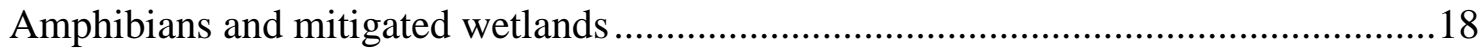

Beaver-created wetlands as reference sites ........................................................21

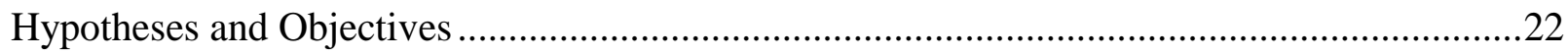

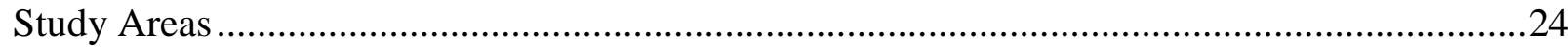

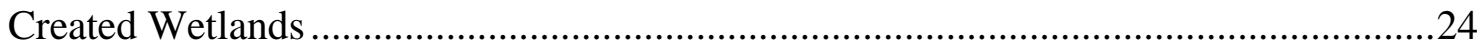

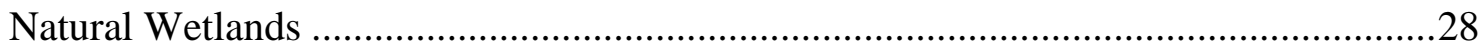

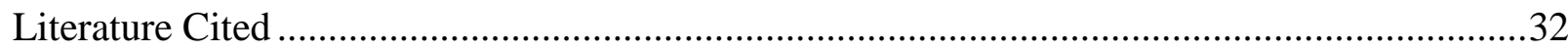

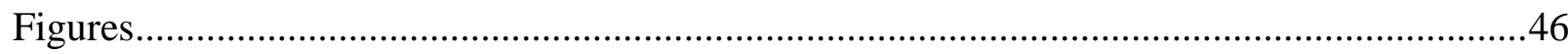

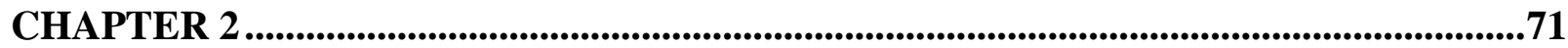

Amphibian Reproductive Success as a Gauge of Functional Equivalency of Created Wetlands in the Central Appalachians ..................................................................................72

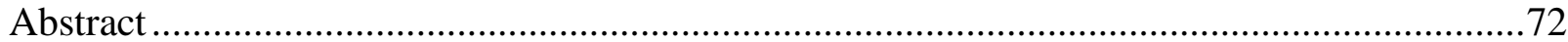

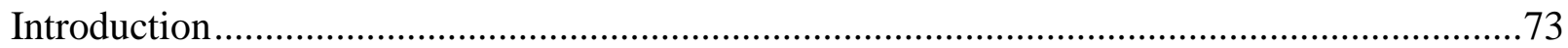

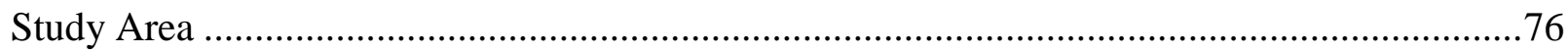

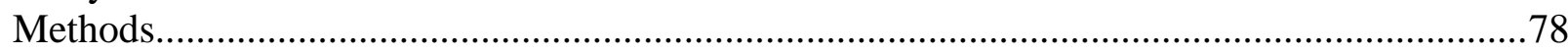

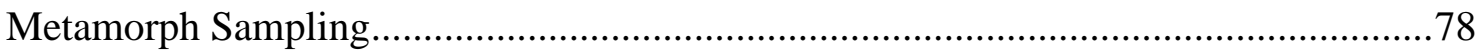

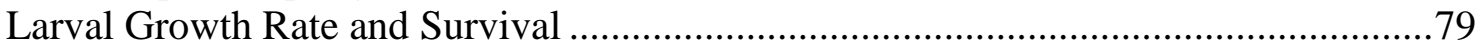

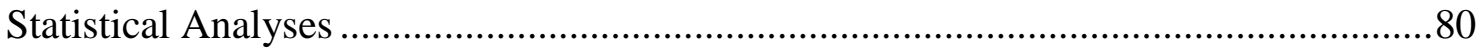

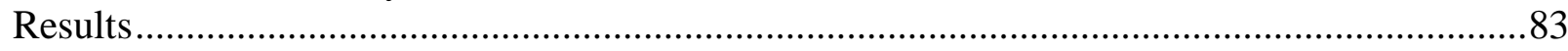

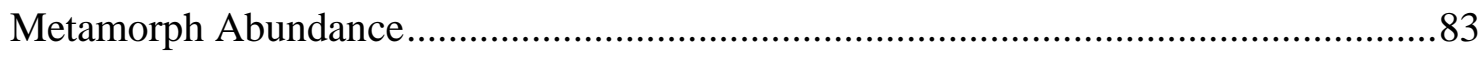

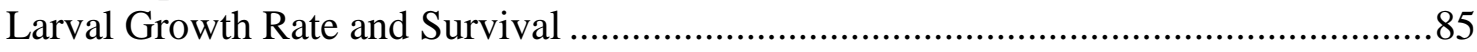

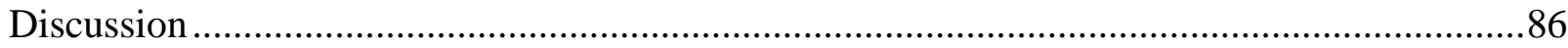




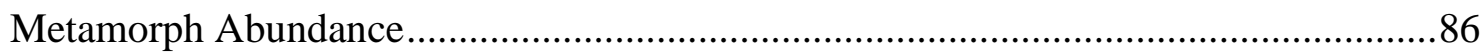

Larval Growth Rate and Survival ..........................................................................91

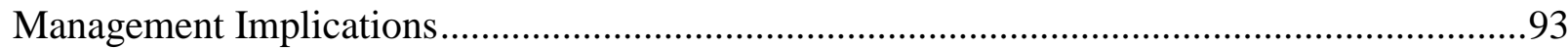

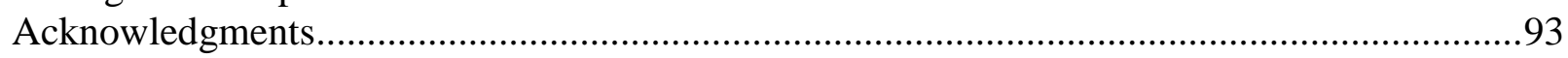

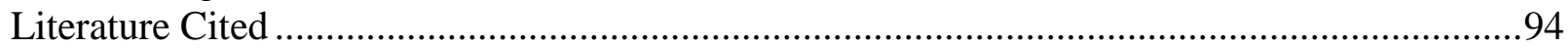

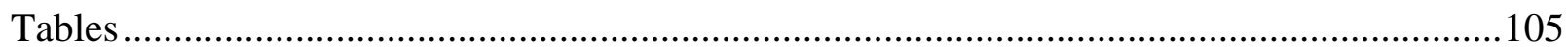

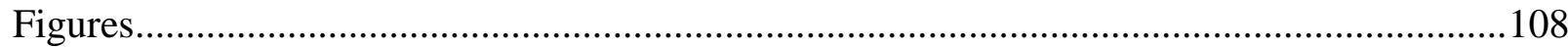

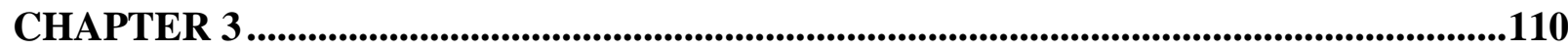

Amphibian occupancy of created wetlands in the Central Appalachians: a test of functional

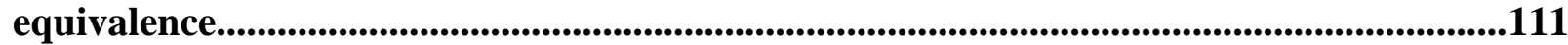

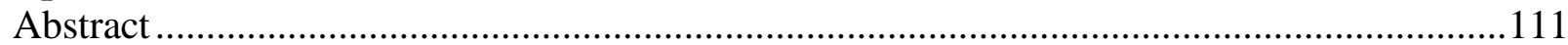

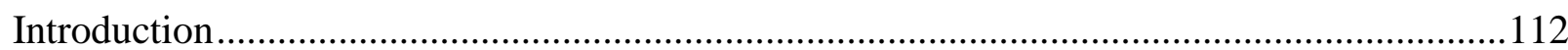

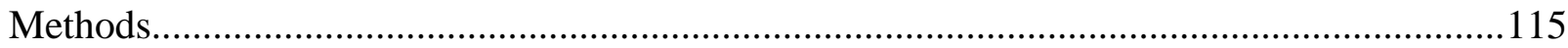

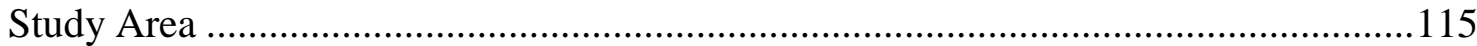

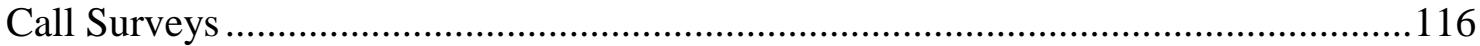

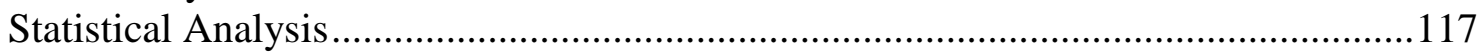

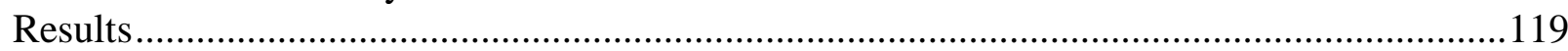

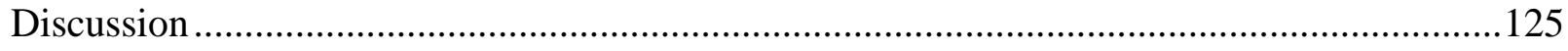

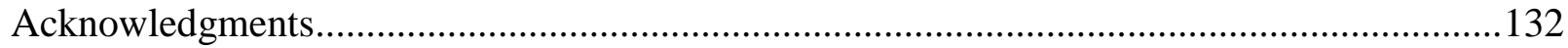

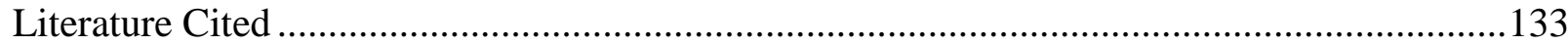

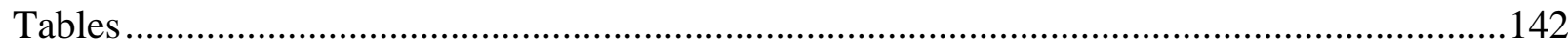

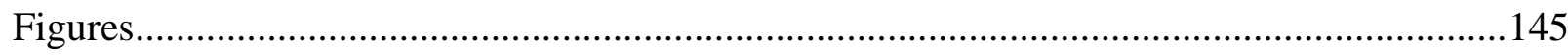

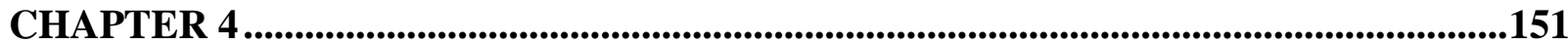

Functional equivalency of created and natural wetlands: diet composition of red-spotted

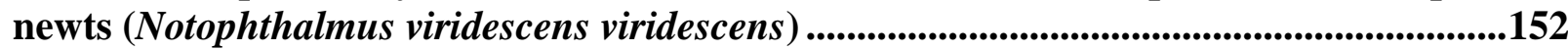

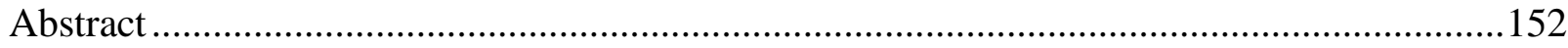

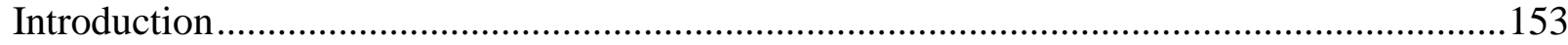

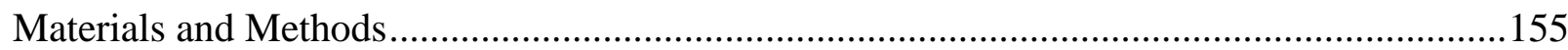

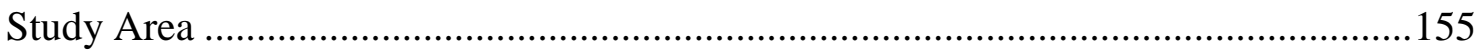

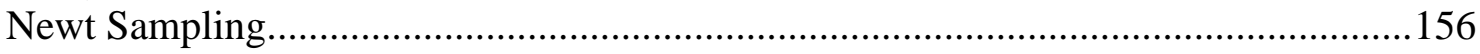

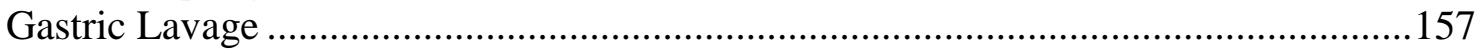

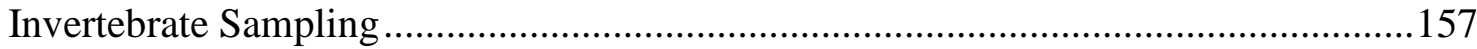

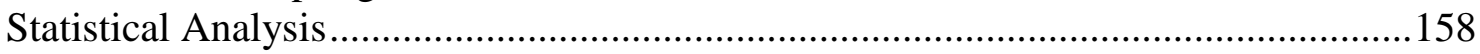

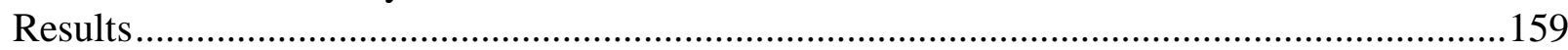

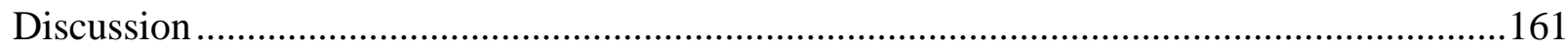

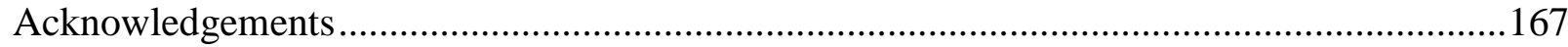

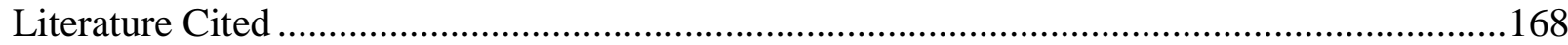

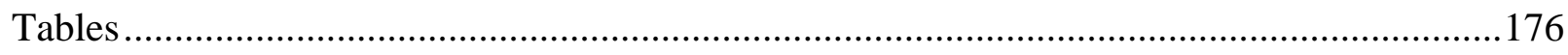

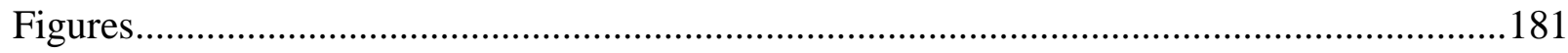


Created wetlands as functionally equivalent amphibian habitat: Synthesis and Applications

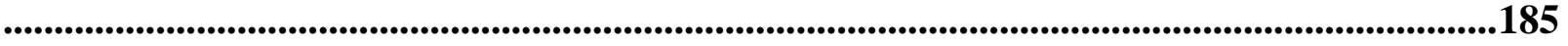

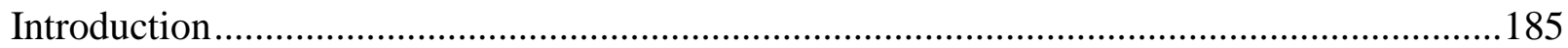

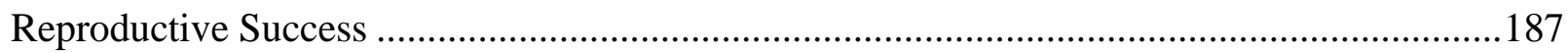

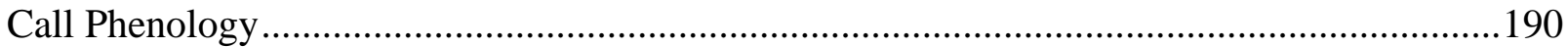

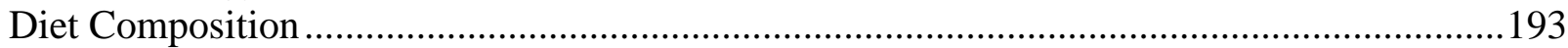

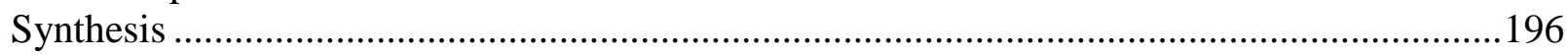

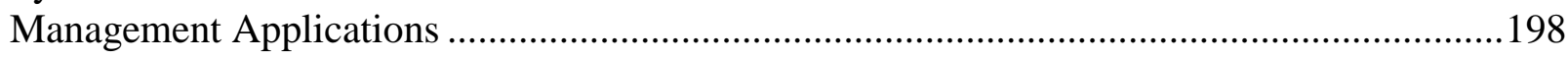

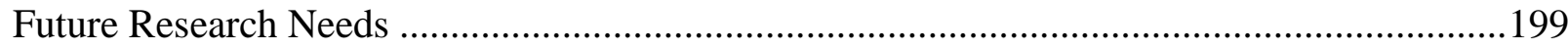

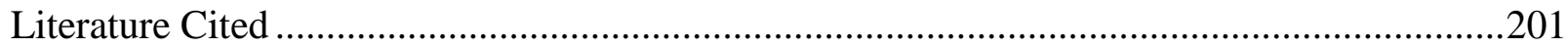




\section{CHAPTER 1. LIST OF FIGURES}

Figure 1. Locations of study sites in West Virginia and Garrett County, Maryland. .46

Figure 2. Photograph of Buffalo Coal 2, a created wetland in Grant County, West Virginia....47

Figure 3. Photograph of Edward's Run, a created wetland in Hampshire County, West Virginia.

Figure 4. Photograph of Elk Run, a created wetland in Grant County, West Virginia.

Figure 5. Photograph of Enoch Branch, a created wetland in Nicholas County, West Virginia.

Figure 6. Photograph of Everhart Seep, a created wetland in Garrett County, Maryland.

Figure 7. Photograph of Hazelton, a created wetland in Preston County, West Virginia. .52

Figure 8. Photograph of Leading Creek, a created wetland in Randolph County, West Virginia.

Figure 9. Photograph of Stauffer's Marsh, a created wetland in Berkeley County, West Virginia.

Figure 10. Photograph of Sugar Creek, a created wetland in Barbour County, West Virginia.

Figure 11. Photograph of Upper Deckers Creek WMA, a created wetland in Preston County, West Virginia.

Figure 12. Photograph of VEPCO, a created wetland in Tucker County, West Virginia. .57

Figure 13. Photograph of Walnut Bottom, a created wetland in Hardy County, West Virginia.

Figure 14. Photograph of Camp 70, a natural wetland in Tucker County, West Virginia. .59

Figure 15. Photograph of Garrett State Forest North, a natural wetland in Garrett County, Maryland.

Figure 16. Photograph of Garrett State Forest South, a natural wetland in Garrett County, Maryland.

Figure 17. Photograph of Glade Run Beaver Pond, a natural wetland in Tucker County, West Virginia. .62 
Figure 18. Photograph of Joe Mood, a natural wetland in Preston County, West Virginia. ......63

Figure 19. Photograph of Kempton Swamp, a natural wetland in Garrett County, Maryland...64

Figure 20. Photograph of Muddlety, a natural wetland in Nicholas County, West Virginia.....65

Figure 21. Photograph of Old Fields, a natural wetland in Hardy County, West Virginia.........66

Figure 22. Photograph of Rail Trail North, a natural wetland in Preston County, West Virginia.

Figure 23. Photograph of Rail Trail South, a natural wetland in Preston County, West Virginia. . .68

Figure 24. Photograph of Short Mountain, a natural wetland in Hampshire County, West Virginia.

Figure 25. Photograph of Upper Deckers Creek, a natural wetland in Preston County, West

Virginia. 


\section{CHAPTER 2. LIST OF TABLES}

Table 1. Attributes of natural $(n=6)$ and created $(n=6)$ wetlands used to study amphibian reproductive success in the Central Appalachians (Size refers to the area of the inundated basin of each wetland and complexity was calculated as $\left(\mathrm{m} / \mathrm{Vm}^{2}\right)$. Hydrogeomorphic (HGM) and Cowardin wetland classifications based on Brinson (1993) and Cowardin et al. (1979), respectively).

Table 2. Number of amphibian metamorphs of each species encountered in created and natural wetlands of the Central Appalachians during 2009 and 2010, with estimated detection probability $(\hat{p})$ and $95 \%$ confidence interval for $\mathrm{p}$ for species with adequate data 106

Table 3. Estimates and $95 \%$ confidence intervals for abundance and detection parameters used in binomial mixture models describing the abundance of spring peeper and green frog metamorphs encountered in created and natural wetlands of the Central Appalachians during 2009 and 2010 (-- indicates that a parameter was not in the final model for that species). 


\section{CHAPTER 2. LIST OF FIGURES}

Figure 1. Locations of natural $(n=6)$ and created $(n=6)$ wetlands used to study amphibian reproductive success in the Central Appalachians, West Virginia and Maryland....................108

Figure 2. Mean mass of green frog tadpoles raised in water from created and natural wetlands of the Central Appalachians (dashed lines represent naive +/- $1 \mathrm{SE}$; SE lines for natural wetlands truncated because tadpoles from only 1 wetland survived beyond week 67)........................109 


\section{CHAPTER 3. LIST OF TABLES}

Table 1. Attributes of natural $(n=12)$ and created $(n=12)$ wetlands used to study call phenology of anurans in the Central Appalachians (Size refers to the area of the inundated basin of each wetland). Cowardin classifications based on Cowardin et al. (1979).

Table 2. Naïve and model-based probability estimates (+/- $1 \mathrm{SE})$ for wetland occupancy ( $\Psi)$ in models describing the occupancy by calling adult anurans encountered in created and natural wetlands of the Central Appalachians during 2009 and 2010 ("N/A" indicates that wetland type and year were not in the final model for Lithobates catesbeianus or L. palustris; naïve estimates based on data from 5-minute call surveys). .143

Table 3. Species richness estimates (+/- $1 \mathrm{SE})$ of calling adult anurans recorded in created and natural wetlands of the Central Appalachians during 2009 and 2010. 


\section{CHAPTER 3. LIST OF FIGURES}

Figure 1. Locations of natural $(n=12)$ and created $(n=12)$ wetlands used to study occupancy of calling adult anurans in the Central Appalachians of West Virginia and Maryland.

Figure 2. Estimated detection probability as a function of wind speed (at the mean of all other environmental variables) for calling adult anurans encountered in created and natural wetlands of the Central Appalachians during 2009 and 2010. 146

Figure 3. Estimated detection probability as a function of Julian day (at the mean of all other environmental variables) for calling adult anurans encountered in created and natural wetlands of the Central Appalachians during 2009 and 2010.

Figure 4. Estimated detection probability as a function of air temperature (at the mean of all other environmental variables) for calling adult anurans encountered in created and natural wetlands of the Central Appalachians during 2009 and 2010.

Figure 5. Estimated detection probability as a function of cloud cover (at the mean of all other environmental variables) for calling adult anurans encountered in created and natural wetlands of the Central Appalachians during 2009 and 2010.

Figure 6. Estimated detection probability as a function of water temperature (at the mean of all other environmental variables) for calling adult anurans encountered in created and natural wetlands of the Central Appalachians during 2009 and 2010. 


\section{CHAPTER 4. LIST OF TABLES}

Table 1. Attributes of natural $(n=6)$ and created $(n=6)$ wetlands used to study red-spotted newt diet selection in the Central Appalachians.......................................................................176

Table 2. Grouping of invertebrate families and orders for analysis of red-spotted newt diets (“--." indicates no further taxonomic resolution).

Table 3. Mean percent use and availability ( $\pm 1 \mathrm{SE})$ of invertebrate prey consumed by redspotted newts inhabiting created and natural wetlands of the Central Appalachians.

Table 4. Ranking matrix for red-spotted newts based on comparison of proportional prey use to proportions of available prey categories (a " + " sign indicates that the prey category in the row is used more than expected relative to the category in the column, whereas a "_" sign indicates that the prey category in the row is used less than expected relative to the option in the column; a triple sign indicates a significant departure from random use at $p=0.05$ ).

Table 5. Significant $(p<0.01)$ pairwise comparisons of the mean differences of log-ratios from compositional analysis for wetland type, season, and month (for each prey category pairing the reference category is listed on the left, and a positive estimate indicates that the reference category is selected less than expected compared to the other category, whereas a negative estimate indicates that the reference category is selected more). 


\section{CHAPTER 4. LIST OF FIGURES}

Figure 1. Locations of natural $(n=6)$ and created $(n=6)$ wetlands used to study red-spotted newt diet selection in the Central Appalachians.

Figure 2. Mean percent occurrence $( \pm 1 \mathrm{SE})$ by prey category in stomachs of red-spotted newts

inhabiting created and natural wetlands of the Central Appalachians. .182

Figure 3. Mean monthly dietary breadth $( \pm 1$ SE) of red-spotted newts inhabiting created and natural wetlands of the Central Appalachians during 2009 and 2010 (different letters indicate significant differences between months at $p=0.05$ ). 183 


\title{
CHAPTER I
}

THE SIGNIFICANCE OF WETLANDS AND WETLAND AMPHIBIANS AND THE ROLE OF COMPENSATORY MITIGATION

\author{
Gabriel F. Strain \\ West Virginia University, Division of Forestry and Natural Resources, PO Box 6125, \\ Morgantown, WV 26506-6125
}

Written in the style of:

The Journal of Herpetology 


\title{
The significance of wetlands and wetland amphibians and the role of compensatory mitigation
}

\author{
GABRIEL F. STRAIN
}

\begin{abstract}
Division of Forestry and Natural Resources, West Virginia University, P.O. Box 6125, Morgantown, WV 26506-6125, USA
\end{abstract}

Introduction.-Wetlands provide important ecosystem services, such as the absorption of excess water, nutrients, and sediments, the release of nitrogen into the atmosphere, and the transformation of sulfates into sulfides (Mitsch and Gosselink, 1993; Tiner, 2002). They also provide unique and crucial habitat to both wildlife and plants (Dahl and Johnson, 1991; Balcombe et al., 2005a). Many amphibian species depend on wetlands and spend all or part of their life cycle in them because they offer excellent sources of food, protection, and breeding opportunities (Gibbons, 2003). In turn, amphibians provide an abundant and high energy food source for larger predators such as birds and mammals (Davic and Welsh, 2004).

However, more than $53 \%$ of the wetland area in the United States has been lost since the 1780s (Dahl, 1990) due to drainage, dredging, hydrologic alterations, and water pollution related to activities such as agriculture, development, and mining (Mitsch and Gosselink, 1993). This loss threatens the biodiversity of amphibians through habitat destruction and loss of connectivity (Semlitsch and Bodie, 1998). A policy of "no net loss" of wetlands in the United States has been established (Turner et al., 2001) and compensatory mitigation, which is the replacement or 
compensation of wetland area and function when permitted damage to natural wetlands is unavoidable, is a major tool used to accomplish this goal (Zedler, 1996; Cole and Shafer, 2002).

In most cases, the success of created wetlands is judged by examining parameters such as hydrology, vegetative cover, or the presence of wildlife; however, the structural similarity of a created wetland to a lost wetland does not necessarily mean that the mitigated wetland functions properly (Campbell et al., 2002). In particular, call surveys for amphibians may not be adequate to determine that created wetlands fulfill the functions necessary to maintain amphibian populations. Adults may call and breed at wetlands, but mortality of larvae and metamorphs may result in reproductive failure (Petranka et al., 2003b). Therefore, assessment of reproductive success, temporal calling patterns, and diet composition of amphibians inhabiting created wetlands is important to facilitate determination of the adequacy of created wetlands as functional replacements of natural wetlands.

\section{Literature Review}

The significance of wetlands.- The United States Army Corps of Engineers defines wetlands as "those areas that are inundated or saturated by surface or ground water at a frequency and duration to support, and that under normal circumstances do support, a prevalence of vegetation typically adapted for life in saturated soil conditions" (Environmental Laboratory, 1987). This frequency of saturation tends to prohibit the establishment of organisms that are unable to tolerate flooded conditions (Brinson and Malvarez, 2002), which leads to assemblages that are often quite different from the surrounding upland area. Wetlands are considered intermediate between fully aquatic and fully terrestrial systems (Dahl, 2006). As such, they function as a buffer between terrestrial systems and lotic and lentic systems, providing important 
ecosystem services (Dahl and Johnson, 1991; Mitsch and Gosselink, 1993). These services include the absorption of excess water, nutrients, and sediments, the release of nitrogen into the atmosphere, and the transformation and storage of detrimental chemicals and compounds such as sulfates and organic carbon, the latter of which contributes to global climate change (Mitsch and Gosselink, 1993; Tiner, 2002).

Wetlands also provide unique and crucial habitat to both wildlife and plants (Dahl and Johnson, 1991; Balcombe et al., 2005a). Approximately one third of federally endangered or threatened plants and animals rely on wetlands (Dahl and Johnson, 1991). The vast array of wetland plants provides food and shelter for an equally vast array of wetland insects (Batzer and Wissinger, 1996). Plant matter and invertebrates in intertidal mangrove and saltmarsh wetlands are an important source of food for multiple trophic levels in estuarine ecosystems (Mazumder et al., 2011). In agricultural settings, small wetlands may increase the biodiversity of an area by providing patches of aquatic habitat (Blackwell and Pilgrim, 2011). Many avian species, such as the palm warbler (Dendroica palmarum) and the yellow-headed blackbird (Xanthocephalus xanthocephalus), use wetlands exclusively for breeding (Weller, 1999; Tiner, 2002), and numerous waterfowl species use wetlands to rest and feed in during migration (Mitsch and Gosselink, 1993). Birds such as American green-winged teal (Anas crecca carolinensis) depend on invertebrate- and seed-rich wetlands for energy during increased periods of feather molt intensity (Anderson et al., 2000). Wetlands not only provide important forage for a number of mammal species including deer (Odocoileus spp.), raccoons (Procyon lotor), skunks (family Mephitidae), and opossum (Didelphis virginiana); they are also home to economically important furbearers such as muskrat (Ondatra zibethicus), beavers (Castor canadensis), mink (Neovison vison), and otter (Lontra canadensis) (Mitsch and Gosselink, 1993; Tiner, 2002). Wetlands also 
are important for other wildlife, including fish, invertebrates, and amphibians. The high biodiversity found in wetlands provides numerous opportunities for recreation and viewing wildlife, ecosystem services highly valued by society (Ghermandi et al., 2010).

Wetlands in the Appalachian Mountain region may be particularly important because of the sometimes rare and unique communities found in them (Francl et al., 2004), their geographic position (south of the former Laurentide ice sheet), and the complexity of the landscape (Byers et al., 2007). In this area, some plant species exist on the edge of their range (Rentch et al., 2008). Riparian wetlands in the Appalachian region may also play an important role in the denitrification of ground water (Flite et al., 2001). Approximately one-fifth of the rare plants in North Carolina occur in these montane wetlands (Murdock, 1994). Webb and Samuel (1982) surveyed wetlands in 31 counties of West Virginia, the "only state which lies entirely within the unglaciated Appalachian region" (Smith and Michael, 1982). They classified 72\% of wetlands as American woodcock (Scolopax minor) habitat, with $43.5 \%$ of the wetlands providing exceptional habitat for this gamebird. Also in West Virginia, Steketee (2000) found that distance to wooded wetlands was the best predictor of woodcock habitat suitability, with $26 \%$ of woodcock flushes occurring in wooded wetlands although wooded wetlands only contributed $1 \%$ to her total study area. Appalachian wetlands are also home to many small mammals, including uncommon species such as the southern bog lemming (Synaptomys cooperi) (Francl and Castleberry, 2004). Some of these wetlands are isolated fens, harboring rare and uncommon plants and animals, but with potentially little protection due to their isolated position in the landscape (Bedford and Godwin, 2003). Rossell and Wells (1999) found that the seed banks of a North Carolina Appalachian fen contained most of the woody seedlings and rushes found in the study, compared 
to a nearby degraded site which contained significantly more sedges and forbs, which suggests that degradation of these small wetlands may result in drastically modified landscapes.

Wetland losses.-Throughout most of United States history, wetlands have been viewed as an impediment to progress (Dahl, 1990; Tiner, 2002). As a result, many wetlands have been destroyed, often with government support (Whigham, 1999; Brinson and Malvarez, 2002). Of the original 89.5 million ha of wetlands in the conterminous United States (circa 1780), approximately 47.3 million ha $(53 \%)$ have been lost (Dahl, 1990); 2.6 million of those have been lost from the mid-1970s to the mid-1980s (Dahl and Johnson, 1991). The loss of forested wetlands alone from about 1940 to 1980 was 68,295 ha annually; the majority of this 2.74 million ha total loss occurred in the Mississippi River Valley (Abernethy and Turner, 1987). Wetland losses have been largest in states such as California (91\% of original wetlands lost), Ohio (90\% lost), and Iowa (89\% lost); however, no state has been immune: West Virginia has lost at least $24 \%$ of its original wetlands (Dahl, 1990; Zedler, 1996). The majority of wetland losses in certain areas of West Virginia occurred prior to 1938 (Ferrell, 1982). Although wetland loss has slowed in recent years (Dahl, 1990), the United States continues to lose 116,000 ha per year (Dahl, 2006), and recent studies demonstrate that losses outweigh gains in overall wetland area (Dahl, 2011).

Wetland losses have been due primarily to drainage and dredging for agriculture, development, and mosquito control, hydrologic alterations designed to dry wetlands, highway construction, mining activities, and water pollution (Mitsch and Gosselink, 1993; National Research Council, 2001). Other sources of wetland degradation include extraction of ground and river water for human use, timber harvesting, and erosion, although the latter is often a natural 
process (Tiner, 2002). The construction of a highway adjacent to Greenbottom Swamp in West Virginia caused an increase in the maximum water depth of the wetland which resulted in the death of the majority of the canopy trees and their replacement by buttonbush (Cephalanthus occidentalis) (Hill and Taylor, 1982). Batzer et al. (2000) found that depressional wetlands harvested for timber in Georgia contained no amphibians and exhibited other physical and biological changes that may persist for years. Species richness of native peatland plants such as Sphagnum were negatively associated with logging and drainage ditches in a large wetland complex in southern Quebec, whereas exotic species were positively associated with disturbance (Tousignant et al., 2010). The withdrawal of groundwater can completely eliminate small depressional wetlands, rendering them unusable by amphibians and other organisms (Brinson and Malvarez, 2002). Climate change is an additional factor affecting wetland loss; coastal wetlands in Louisiana are subsiding at a high rate, and lost with them is the capacity to store and sequester a significant amount of carbon (DeLaune and White, 2012). The effects of climate change on wetlands may be exacerbated by anthropogenic alterations because the fragmentation caused by these activities may prevent organisms such as amphibians from successfully dispersing (Brinson and Malvarez, 2002).

The U.S. Army Corps of Engineers (USACE), which oversees the permitting process for wetland development, allows unpermitted alteration of small wetlands less than 0.2 ha (National Research Council, 2001), and this may negatively impact certain populations of amphibians that are only found in those small water bodies (Snodgrass et al., 2000). Unrestricted development of these small wetlands also compromises connectivity between these and larger wetlands, and thus Semlitsch and Bodie (1998) and Gibbs (2000) suggested that all wetlands greater than 0.4 ha and $0.2 \mathrm{ha}$, respectively, require protection to minimally conserve the integrity of the wetland 
"mosaic" and preserve species biodiversity. Small and large wetlands alike, however, may also be lost due to the language of the Clean Water Act Section 404 program, which gives agencies such as the USACE jurisdiction only over the discharge of dredge or fill material in wetlands with a nexus to navigable waters, not over other actions detrimental to wetlands or to isolated wetlands (National Research Council, 2001).

Although individual development projects that drain or otherwise impact wetlands may not greatly reduce wetland function on a large scale, the cumulative effects of multiple projects can have serious implications (Allen and Feddema, 1996; Race and Fonseca, 1996). The enormous and continuous loss of wetlands in the United States seriously jeopardizes the potential of what remains to provide valuable ecosystem services such as floodwater and sediment retention (Dahl, 1990). This loss also threatens the biodiversity of such taxa as amphibians through habitat destruction and loss of connectivity (Semlitsch and Bodie, 1998).

Compensatory mitigation.-Attempts to stem the loss of wetlands in the United States began in 1972 with passage of the Clean Water Act (CWA; Allen and Feddema, 1996). The majority of wetlands are protected under the CWA because of the beneficial contribution wetlands make to water quality (National Research Council, 2001), although the 2001 SWANCC decision (Solid Waste Agency of Northern Cook County versus U.S. Army Corps of Engineers, in which it was ruled that migratory bird use of isolated non-navigable waters was not sufficient to declare USACE jurisdiction via the Clean Water Act) and other recent court decisions severely reduced or eliminated Federal protection of some isolated, non-navigable, and unique wetlands such as Appalachian fens (National Research Council, 2001; Bedford and Godwin, 2003; Christie and Hausmann, 2003). A policy of "no net loss" of wetlands was established 
during the first Bush administration (Turner et al., 2001), which simply means that the net gains of wetlands must outweigh the net losses. This policy was endorsed by President Clinton (Zedler, 1996) and the second Bush administration (Dahl, 2006), but the Obama administration has not publicly adopted a specific wetland policy (Copeland, 2010). Currently, mitigation banking, the practice of creating wetlands prior to their destruction, is the preferred mitigation option. The U.S. Army Corps of Engineers, in cooperation with the Environmental Protection Agency, is the agency tasked with reviewing development proposals that potentially impact wetlands (Bartoldus, 1994).

Although avoidance of wetland impacts is preferred, the successful execution of the no net loss policy necessarily rests on compensatory mitigation, which is the replacement or compensation of wetland area and function when permitted damage to natural wetlands is unavoidable (Zedler, 1996; Cole and Shafer, 2002). Mitigation involves the creation of wetlands where they did not previously exist, the restoration or enhancement of existing wetlands, or in some cases the preservation of other existing wetlands (Allen and Feddema, 1996; Race and Fonseca, 1996; National Research Council, 2001). To further ensure the success of mitigation projects, mitigation ratios are often required. Mitigation ratios are "the proportional requirements for replacing wetlands that are permitted for fill," and they are often used to offset impacts for which compensation is difficult or will take a long time (National Research Council, 2001). For example, in West Virginia, mitigation ratios are 1:1 for open water wetlands, 2:1 for emergent wetlands, and 3:1 for scrub-shrub and forested wetlands (WV Title 47 CSR 5A). Mitigation ratios are also used to adequately characterize the functional values of lost wetlands, so that a wetland with high functional value would have a high ratio value, whereas a degraded site would have a lower ratio value (National Research Council, 2001). 
These created or restored wetlands are assumed to eventually fulfill the same functions as the natural wetlands they replace (Cole and Shafer, 2002). For example, 20 year-old created wetlands in the Appalachian plateau of Virginia supported plant communities composed of $91 \%$ perennials as opposed to the annuals that normally dominate the composition of newly created wetlands (Atkinson et al., 2005). In some cases, mitigation provides an opportunity to replace a poorly functioning wetland (such as one impacted by urban development) with a high quality wetland (McCuskey et al., 1994). However, not only is the area of the created wetlands often less than it should be (Robb, 2002), compensation of lost wetland area rarely equals compensation of lost wetland function (Turner et al., 2001), although the latter is almost impossible to determine because data quantifying the functions of lost wetlands typically do not exist, nor are mitigation projects monitored for compliance (National Research Council, 2001). This would suggest that the policy of no net loss of wetlands has fallen short of success (National Research Council, 2001; Robb, 2002).

Are created wetlands successful?.-The success or failure of a created wetland can be difficult to assess. There are generally two means by which to gauge success: determining whether or not the created wetland performs the same functions as the lost wetland, or comparing the created wetland against similar reference wetlands (Mitsch and Wilson, 1996).

Function consists of "all physical and chemical properties of a structure that relate to its form and organization" (Lincoln et al., 1998). In wetlands, major functions include hydrology, water quality, sustained habitat for plants and animals, and soil functions (National Research Council, 2001). It is the combination of all of these functions that results in a self-sustaining wetland, which should be the ultimate goal of any mitigation project (National Research Council, 
2001). Gauging success by assessing function is ideal, but often difficult to implement because wetland functions are not as easy to measure as are other parameters, such as percent cover of vegetation and species lists (Mitsch and Wilson, 1996; Zedler, 1996; Cole and Shafer, 2002). Only approximately $2 \%$ of all permits in the United States reviewed by the EPA have a functional assessment component, which illustrates this difficulty (Ainslie, 1994).

The second option, comparing mitigation projects to reference conditions, is akin to using performance standards in the engineering and manufacturing industries; in the case of compensatory mitigation, the standards consist of natural wetlands (Brinson and Rheinhardt, 1996). To assess the biological health of wetlands, indices of biotic integrity (IBIs) have been developed by many states, such as the Ohio IBIs for plants, invertebrates, and amphibians (Micacchion, 2002), in which pristine or nearly so wetlands are used as a reference against which to compare wetlands throughout the region.

Wetland researchers suggest that an important step in gauging the success of compensatory mitigation is to compare created wetlands to appropriate reference wetlands (e.g., Whigham, 1999; Campbell et al., 2002). When compared against the wetlands that were lost, Wilson and Mitsch (1996) found that $80 \%$ of the mitigation projects that they examined in Ohio were legally compliant, overall successful, and replaced the same type of wetlands that were lost. Invertebrate communities were found to be similar in a comparison between ten natural and ten restored Minnesota prairie wetlands (Zimmer et al., 2000). In West Virginia, Balcombe et al. (2005b) found that most plant metrics between mitigated and reference wetlands were similar, with submerged aquatic vegetation and woody vegetation successfully established at ten of eleven mitigation sites. Although the plant species composition in the two types of wetlands was different, the mitigated sites had higher species diversity and did not have more non-natives than 
the reference sites. This is important because mitigation sites, which usually lack vegetation, have large canopy gaps and are eutrophic, are often prone to invasive species (National Research Council, 2001). Also in West Virginia, Balcombe et al. (2005a; 2005c; 2005d) found that mitigated wetlands overall scored better than reference wetlands for many vegetation, anuran, avian, invertebrate, and habitat metrics. Studying some of the same West Virginia wetlands, Gingerich and Anderson (2011) found that decomposition rates of several native plants were similar between mitigated and natural wetlands. Although a created wetland in Virginia had different plant species composition than a reference marsh, both wetlands had similar standing crops, suggesting that the created wetland may function similarly to the reference site (DeBerry and Perry, 2004).

These apparent successes, however, may be the exception rather than the norm for the large majority of mitigation projects. In a comparison of natural marshes and 4-year old constructed marshes in the Sweetwater Marsh National Refuge in California, the natural marshes had 2-3 times more invertebrates than constructed marshes (Scatolini and Zedler, 1996). The authors suggested that differences in sediments, organic matter, and vegetative cover caused the observed differences in abundance. In Massachusetts, the plant community in mitigated wetlands consisted of fewer species with less total cover when compared to natural wetlands (Brown and Veneman, 2001). The authors also found that $54 \%$ of the mitigated wetlands they examined failed to comply with the conditions of permits because they had not been constructed, were too small or too dry, or lacked appropriate vegetation. The hydrology of natural and created wetlands in Pennsylvania that Cole and Brooks (2000) examined was considerably different, as the created wetlands had a much higher water table and a more frequently saturated root zone than reference wetlands. This is an important difference because hydrology is a large determinant of all the 
elements of a wetland (Bedford, 1996; Cole and Brooks, 2000). Another study in Pennsylvania found that between natural and created wetlands, the soil in natural wetlands consisted of much more organic matter and the plant community had higher species richness and higher vegetative cover (Campbell et al., 2002). Robb (2002) found that although 1.45 ha of wetlands were gained through mitigation projects in Indiana, certain types of wetlands such as palustrine forests and wet meadows actually decreased in net area because of the high failure rate of those types of replacement wetlands. In a review of 621 created or restored wetlands throughout the world, Moreno-Mateos et al. (2012) found that biological structure and biogeochemical functioning was approximately $25 \%$ lower in created or restored wetlands compared to reference wetlands. The authors suggest that given current wetland mitigation policies, significant net wetland loss will continue to occur.

The age of a mitigation project also largely influences its apparent success. Zedler and Callaway (1999) predicted that, although mitigation projects are assumed to match reference conditions in a relatively short time span, soil organic matter and total Kjeldahl nitrogen in created wetlands at the Sweetwater Marsh National Wildlife Refuge will need 22 and 40 years, respectively, to reach reference conditions. Balcombe et al. (2005b) found that the age of a mitigation project influenced the species richness of vegetation, with younger sites having greater richness than older sites. Age also influenced plant community composition - older mitigation sites were more similar to the reference sites than were younger sites. The authors suggested that it was the recently disturbed nature of younger sites that allowed them to support more species. These results further reinforce the need to incorporate long-term monitoring into the evaluation of mitigation projects, which may change drastically after the typical five-year monitoring period has concluded (Balcombe et al., 2005c; Spieles et al., 2006). 
Even if a created wetland is legally deemed a success, it does not mean that it is ecologically successful at replacing the wetland that has been lost (Mitsch et al., 1998; Turner et al., 2001). This is because the structural similarity of a created wetland to a lost wetland does not necessarily equate to functional similarity (Campbell et al., 2002). Although a North Carolina restored wetland had similar biotic and abiotic soil elements compared to a natural wetland, the denitrification potential and the drivers of this function between the two wetlands were different (Sutton-Grier et al., 2011). Water chemistry and hydrology were similar between created and natural freshwater marshes in Ohio, but created marshes stored less carbon in litter and soil and processed less nitrogen than natural marshes (Hossler et al., 2011). Turner et al. (2001) found that only $10 \%$ of mitigation permits in California required the replacement of common functions of wetlands such as flood storage and water quality improvement, and only $21 \%$ of mitigation projects succeeded in developing functional replacement wetlands. Cole and Shafer (2002) suggested that although Pennsylvania gained wetland area through mitigation, there was a net loss of function because many types of wetlands were replaced with open water ponds or uplands. This is the same reason that Robb (2002) found net losses of palustrine forested wetlands - they were replaced by shallow marshes, open water, and palustrine aquatic bed wetlands. Cole and Shafer (2002) also found that in Pennsylvania, scrub-shrub and forested wetlands were replaced with wetlands dominated by emergent vegetation and open water. In the Appalachian Mountain region of Virginia, Atkinson and Cairns (2001) found that decomposition rates of plants in 20 year-old created wetlands were higher than in 2 year-old wetlands but that the higher rate was still lower than values reported for natural wetlands, and they concluded that "decomposition functions of these wetlands are still developing 20 years after creation." Pressure to meet hydrological requirements often results in the popular mitigation concept that "wetter is 
better," which may be causing replacement wetlands to not only differ structurally from the lost wetlands, but functionally as well (Cole and Brooks, 2000; National Research Council, 2001). To combat this issue and create wetlands that are functioning as close to natural conditions as possible, the preference has been for mitigation projects that are on-site and in-kind (Race and Fonseca, 1996); however, this often places mitigated wetlands amid disturbed conditions, which may limit the quality of the resulting wetland (National Research Council, 2001).

The problem may be that we just do not know enough yet about wetlands to be successful in replacing them (Whigham, 1999). For example, certain types of wetlands such as fens and bogs are presently impossible to restore (National Research Council, 2001). Therefore, for compensatory mitigation to succeed, more information about how wetlands function and how to incorporate those functions into the assessment of wetlands is needed (Zedler, 1996).

Wetlands are important to amphibians.-Although amphibians are often neglected, they constitute a large portion of the fauna in freshwater wetlands (Gibbons, 2003). Many amphibian species use wetlands for all or part of their life cycle. In West Virginia, 24 species of amphibians have been recorded in or near wetlands, and 22 species are considered wetland obligates (Pauley, 2000).

The variable hydroperiod that most wetlands exhibit is important: the adults of some species, such as the wood frog (Lithobates sylvaticus) and the spotted salamander (Ambystoma maculatum), avoid ovipositing in bodies of water permanent enough to support fish because fish predation significantly reduces larval survivorship (Hopey and Petranka, 1994; Petranka and Holbrook, 2006). Pechmann et al. (1989) observed in a large South Carolina wetland that two species, the eastern narrow-mouthed toad (Gastrophryne carolinensis) and the pine woods 
treefrog (Hyla femoralis), only successfully reproduced once a site had dried and then refilled later in the season. Wilbur (1972) suggested that it is the variable nature of wetland hydroperiods that has led to the ecological plasticity exhibited by many amphibians, such as Ambystomatid salamanders.

A precise balance between excluding fish via temporary drying and maintaining water long enough for larvae to achieve metamorphosis is important. However, Paton and Crouch (2002) found that New England breeding ponds need to hold water for at least five months to allow $50 \%$ of metamorphs of some species to emerge successfully. Hydroperiod was a strong predictor of spotted salamander and wood frog egg mass abundance in New Hampshire wetlands (Veysey et al., 2011). Similarly, Pechmann et al. (1989) found that the total number and species richness of metamorphosing individuals was positively correlated with hydroperiod. They also found that the ditching of another nearby wetland altered its hydroperiod and will likely cause the extirpation of the mole salamander (Ambystoma talpoideum) in that wetland.

The larvae of amphibian species depend on wetlands to provide food for growth to reach metamorphosis: anuran larvae feed on algae and detritus, which they obtain through filtering suspended particles in the water or scraping from the substrate (Duellman and Trueb, 1994); salamander larvae are strictly carnivorous and typically feed on any aquatic invertebrate that will fit into their mouths (Duellman and Trueb, 1994). Anuran larvae can regulate primary production through their consumption of algae, and primary production increases significantly once tadpoles leave the wetland via metamorphosis (Seale, 1980). In turn, the wetland plant community may impact amphibians; invasive plants that contribute detritus with high carbon-to-nitrogen ratios may negatively affect both the number of amphibian species that metamorph and the total number of metamorphs produced (Maerz et al., 2010). Anuran larvae also prey on invertebrates 
and the eggs of other amphibian species, the impacts of which can be significant. Petranka and Kennedy (1999) found that the survival of oligochaetes and chironomids was greater than $98 \%$ in the absence of wood frog tadpoles, but dropped to $24-54 \%$ in their presence. The authors also found that when northern green frog (Lithobates clamitans) tadpole densities are high $\left(>15 / \mathrm{m}^{2}\right)$, the mortality of wood frog eggs is close to $100 \%$.

Typically, amphibian larvae transform and emerge from the wetland in late spring or summer, but in most cases they live the majority of their lives in close proximity to the wetland because it offers excellent sources of food, protection, and breeding opportunities (Gibbons, 2003). In Ontario wetlands, most species' occurrences, including the northern green frog, wood frog, gray treefrog (Hyla versicolor), spotted salamander, and spring peeper (Pseudacris crucifer), were positively associated with extensive forest cover (Houlahan and Findlay, 2003). Enge and Marion (1986) trapped ten times as many amphibians in forested habitat surrounding a northern Florida cypress swamp than in clearcuts. However, heterogeneous habitat surrounding wetlands may be ideal because wood frog and spring peeper larvae grew $90 \%$ and $83 \%$ faster, respectively, in open canopy as opposed to closed canopy habitats (Skelly et al., 2002). The runways and burrows of small mammals commonly found near wetlands, such as northern shorttailed shrew (Blarina brevicauda) and mice (Peromyscus spp.), provide crucial overwintering habitat for the adults and juveniles of some amphibian species, such as spotted salamanders and northern green frogs (Madison, 1997; Lamoureux and Madison, 1999).

All adult amphibians are carnivorous and consume primarily invertebrates (Duellman and Trueb, 1994), which most wetlands provide in abundance (Batzer and Wissinger, 1996). Because of this diet, amphibian populations may have considerable impact on the structure of wetland invertebrate communities, such as in Texas playas (Smith et al., 2004). Female mosquitos avoid 
ovipositing in seasonal wetlands inhabited by larval amphibians because of predation risk, which has positive consequences for humans due to a reduction in mosquito-borne illnesses (Rubbo et al., 2011). In turn, amphibians provide an abundant and high energy food source for larger predators such as birds and mammals (Davic and Welsh, 2004). Not only do amphibians depend on individual wetlands, but the amount and position of wetlands across the landscape is important in maintaining connectivity and enabling amphibians to move among wetlands (Semlitsch and Bodie, 1998; McCauley and Jenkins, 2005). Indeed, the destruction or alteration of wetland habitats, including the surrounding terrestrial landscape (Pope et al., 2000; Marsh and Trenham, 2001), may just be one of the many factors contributing to the current global decline of amphibian populations (Phillips, 1990; Alford and Richards, 1999); other possible factors include increased UV-B radiation, introduced predators, disease, climate change, and interactions among these (Alford and Richards, 1999). Veysey et al. (2011) demonstrated that the density of roads and continuous forest within $1000 \mathrm{~m}$ of wetlands were strong predictors of amphibian egg mass abundance. Although Petranka et al. (2003b) found that amphibians quickly colonized created ponds, it may be difficult for some species to colonize or recolonize newly created or restored wetlands because of physiological pressures associated with moving from one wetland to another, the small home range size of typical species, and the tendency of amphibians to remain at their natal pond (Berven and Grudzien, 1990; Blaustein et al., 1994).

Amphibians and mitigated wetlands. - Created and mitigated wetlands have had varying degrees of success in supporting amphibian populations. In North Carolina, Petranka et al. (2003a) found that ponds in a mitigation bank produced numbers of juveniles similar to reference ponds over a seven year period, and some adults moved from their home ponds to breed in the 
mitigated ponds. However, due to a ranavirus outbreak, the breeding population in their study was smaller after the construction of the mitigation bank than before, and therefore the ability of their mitigated wetlands to maintain breeding populations that are equivalent to natural wetlands is uncertain. Another study which examined the same mitigation bank as in Petranka et al. (2003b) found that during the first year after construction seven species colonized and bred in the created ponds, and species richness was higher in created than in reference ponds (Petranka et al., 2003b). In a comparison of natural and mitigated vernal pools in central Ohio, Korfel et al. (2010) found that, although the created pools did not replicate natural vernal pool hydrology, they supported similar biomass of amphibian larvae and higher familial diversity than natural pools. Eight species of amphibians were found in recently restored Minnesota wetlands out of the 12 species found in reference wetlands, but successful breeding (as determined by the presence of late-stage larvae and metamorphs) in restored wetlands was observed for only four of those species (Lehtinen and Galatowitsch, 2001). Also in Minnesota, species richness and reproductive success (based on an index which incorporated numbers of eggs, larvae, metamorphs, and juveniles) in created ponds surrounded by row crops and pasture was similar to that of natural wetlands, but reproductive success was significantly less in created ponds to which cattle had access because of a reduction in water quality (Knutson et al., 2004). In Georgia, American bullfrog (Lithobates catesbeianus) larvae inhabiting wetlands created for wastewater treatment experienced a much higher rate of sometimes severe abnormalities than larvae in reference wetlands (Ruiz et al., 2010). Because metamorphs of the mole salamander (Ambystoma talpoideum) and the eastern red-spotted newt (Notophthalmus viridescens) were larger in created ponds than in a natural reference wetland in South Carolina, Pechmann et al. (2001) suggested that the created ponds provide adequate amphibian habitat; however, 
differences in species composition between the two types of wetlands led the authors to conclude that the created wetlands provided only partial mitigation. In West Virginia, Balcombe et al. (2005a) found that mitigated wetlands supported seven species of amphibians, the same species pool found in reference sites. They also found that Wisconsin call index values and relative abundance were higher in mitigated wetlands for three species, and similar between mitigated and reference sites for the remaining species. However, declaring success of mitigated wetlands based solely on call index values may be misleading if calling adults are not successfully reproducing (Petranka et al., 2003b).

The common practice of making mitigated wetlands wetter (Cole and Brooks, 2000) and thus more permanent may negatively affect the diversity of amphibians in a region because there are many species which breed exclusively in temporary bodies of water (Snodgrass et al., 2000). More permanent wetlands have a greater chance of supporting fish than do temporary wetlands, and the presence of fish can have a significant impact on amphibian populations (Knutson et al., 2004). Bronmark and Edenhamm (1994) suggested that fish most likely decrease the reproductive success of the common tree frog (Hyla arborea) via predation on tadpoles, and wood frog adults avoid breeding in ponds containing fish (Petranka et al., 1994). Balcombe et al. (2005d) found that mitigated wetlands in West Virginia had much higher proportions of open water $(40.6 \%)$ than reference wetlands $(9.3 \%)$, and 9 out of 11 mitigated wetlands contained fish, although the presence of fish did not appear to affect the health of amphibian populations in their study (Balcombe et al., 2005a). Constructing wetlands as open water bodies may provide suitable habitat for permanent-water species such as American bullfrogs and green frogs, but may prevent other taxa such as salamanders and hylid frogs from persisting due to the presence of fish (Shulse et al., 2010). Wetland construction that narrowly focuses on ensuring wetland hydrology by 
creating open water ponds may neglect the vegetated portion and surrounding uplands of created wetlands (Zedler, 1996), habitat components that are vital to amphibians (Lamoureux and Madison, 1999; Lehtinen et al., 1999; Pope et al., 2000; Gibbons, 2003).

Beaver-created wetlands as reference sites.-Beavers were extirpated from the state of West Virginia by 1825, were restocked from 1933-1940 for trapping, and have been a component of the fauna of the state since (Bailey, 1954). Beavers are textbook examples of allogenic ecosystem engineers because they directly alter the hydrology of streams, via the activity of cutting down trees and forming a dam, which "modulate[s] the availability of resources to other species" (Jones et al., 1994). One of these resources is the water itself, which is transformed from a flowing stream into an impoundment; this transformation increases the amount of open water and emergent wetlands in a watershed (Cunningham et al., 2006).

Wetlands created by beaver in Maryland altered the water chemistry, including increasing both the ANC and $\mathrm{pH}$, compared to the streams above and below the impounded areas (Margolis et al., 2001a). These water chemistry changes, along with changes in plant growth and water temperature, caused the benthic macroinvertebrate assemblages in the beaver-created wetlands in Maryland to also vary significantly from the streams against which they were compared (Margolis et al., 2001b). The shift in macroinvertebrates that occurs in beaver-created wetlands results in an assemblage that is similar to natural wetlands (Hodkinson, 1975; Naiman et al., 1988). Historic beaver ponds may play a role in the maintenance of rare species, as Bonner et al. (2009) found that older beaver ponds tended to support more rare species in West Virginia's Canaan Valley. Over time, the water chemistry, plant, and macroinvertebrate changes result in 
wetlands that provide important habitat for wetland-dependent species of amphibians, such as wood frogs, American bullfrogs, and pickerel frogs (Lithobates palustris) (Cunningham, 2003).

Beaver-created wetlands do not represent the typical wetlands that mitigation projects in West Virginia are designed to replace, as the majority of natural wetlands in the state contain little standing water (Cole and Brooks, 2000). However, reference sites should be a close match to mitigated sites in as many aspects as possible, such as environmental conditions and geographical location, to facilitate comparisons (White and Walker, 1997). The majority of created wetlands tend to be dominated by open water (Cole and Brooks, 2000), and mitigated wetlands in West Virginia also have a large proportion of open water compared to natural wetlands (Balcombe et al., 2005d). As such, historic beaver-created wetlands may approximate the conditions of these created wetlands as amphibian habitat more so than other wetland types in the state.

\section{Hypotheses and Objectives}

Although created wetlands may develop to be structurally similar to natural wetlands, they may not function similarly. Common measures of created wetlands such as vegetative cover and presence of wildlife will not detect this lack of function. I hypothesized that because created wetlands represent anthropogenically disturbed conditions that may not maintain all of the functional aspects of natural wetlands, the reproduction of their resident amphibians is less successful than in natural wetlands. The objectives I used to test this hypothesis were:

1. Examine the shifts in densities of amphibian metamorphs over time in created wetlands relative to natural wetlands. 
2. Examine the survival and growth rate of larval amphibians in created wetlands relative to natural wetlands.

Call surveys for amphibians are a typical way to gauge the amount of wildlife use in created wetlands, which may be used to determine the success of mitigation projects. However, problems associated with standard manual call surveys may render them inaccurate. I hypothesized that standard five-minute call surveys miss species that call sporadically and easily disturbed species may not return to calling within the five-minute survey. Additionally, using broadcasts of advertisement calls to elicit responses from amphibians may increase the return of manual call surveys with a minimum of additional effort. The objective I used to test this hypothesis was:

1. Compare detection probabilities of species between five-minute manual call surveys, ten-minute manual call surveys, and broadcast calls.

For created wetlands to be deemed appropriate replacements for lost natural wetlands, call surveys in created and natural wetlands should yield similar results. If this is not the case, abnormal calling behavior or lower abundance may result in fewer matings, and thus the breeding success of anurans in mitigated wetlands will be compromised. I hypothesized that this lack of appropriate conditions will cause call indices of amphibians calling at created wetlands to be lower than those at natural wetlands. The objective I used to test this hypothesis was:

1. Compare the call indices of amphibians in created wetlands to those in natural wetlands, and examine factors that may influence these indices.

Although invertebrate assemblages between created and natural wetlands may be similar, amphibians may be selecting and consuming different prey between the two wetland types, which would suggest that created wetlands are not functioning similarly to natural wetlands. I 
hypothesized that the diet composition and prey selection of amphibians differed between natural and created wetlands because differences in functional aspects between the wetland types affects the availability of invertebrates as prey or the ability of amphibians to forage successfully. The objectives used to test this hypothesis were:

1. Compare the diet composition of red-spotted newts between created and natural wetlands.

2. Compare use and selection of prey items by red-spotted newts between created and natural wetlands.

\section{Study Areas}

Twelve created and twelve reference wetlands were selected for study (Fig. 1). The created wetlands were Buffalo Coal 2, Edward's Run, Elk Run, Enoch Branch, Everhart Seep, Hazelton, Leading Creek, Stauffer's Marsh, Sugar Creek, VEPCO, Walnut Bottom, and Upper Deckers Creek WMA. The reference wetlands were Camp 70, Garrett State Forest North, Garrett State Forest South, Glade Run, Joe Mood, Kempton Swamp, Muddlety, Old Fields, Rail Trail North, Rail Trail South, Short Mountain, and Upper Deckers Creek.

\section{Created Wetlands}

Buffalo Coal 2.-The Buffalo Coal 2 wetland is named as such to distinguish it from another wetland owned by the Buffalo Coal Company that has been used in previous studies (Balcombe et al., 2005a; 2005b; 2005c; 2005d). This wetland is located in Grant County, West Virginia, and is a largely open water pond that sits at an elevation of $1,018 \mathrm{~m}$ and is approximately 2.8 ha in area (Fig. 2). 
Edward's Run.-This created wetland is located in the northern portion of the Edward's Run Wildlife Management Area located in Hampshire County, West Virginia. The wetland lies along Edward's Run, which is a tributary of the Cacapon River. It is 2.2 ha in area and lies at an elevation of $250 \mathrm{~m}$. This wetland is predominantly open water, but also includes wet meadow, forested, and sphagnum mat areas (Fig. 3).

Elk Run.-The Elk Run wetland is located in Grant County, West Virginia, and is described in Balcombe (2003). It is owned by the Island Creek Coal Company, and was constructed in 1981 as mitigation for a water treatment facility. It sits at an elevation of $840 \mathrm{~m}$ and is 3.8 ha in area. Two cells comprise this wetland; the first is a large open water pond, and the second is a temporarily flooded emergent/scrub-shrub wetland dominated by rough arrowwood (Viburnum dentatum) and cattail (Typha latifolia) (Fig. 4).

Enoch Branch.-This wetland is located in Nicholas County, West Virginia, and is described in Balcombe (2003). It was created in 1997 by the WVDOH as mitigation for the construction of U.S. Route 19. It sits along Muddlety Creek at an elevation of $620 \mathrm{~m}$. This wetland consists of two semi-permanently to permanently flooded open water cells. The dominant emergent vegetation is common rush (Juncus effusus), and brookside alder (Alnus serrulata) runs along the edge of the western cell. The site is 3.4 ha in area, but this study focused on the western cell, which is 1.7 ha (Fig. 5). 
Everhart Seep.-The Everhart Seep wetland is located in Garrett County, Maryland, on the Glades Preserve, which is owned by The Nature Conservancy. The wetland is 0.12 ha and sits an elevation of $812 \mathrm{~m}$. This wetland lies below a successive alkalinity producing system, which is a series of ponds designed to treat acid mine drainage seeping from a nearby abandoned mine. The system is designed to raise the $\mathrm{pH}$ of the water and remove iron, and the treated water drains into the wetland. The wetland consists of open water and scrub-shrub and emergent vegetation areas. The vegetation consists primarily of grasses, sedges (Carex spp.), rushes (Juncus spp.), burreed (Sparganium americanum), and bulrush (Scirpus spp.) (Fig. 6).

Hazelton.-The Hazelton wetland was created in 2006 by the WVDOH as mitigation for highway construction. It is located in Preston County, West Virginia, just off of Route 68 (Hazelton, exit 29). The wetland is 8.5 ha, has an elevation of $560 \mathrm{~m}$, and is situated along three streams: Cherry Run and Mill Run empty into Little Sandy Creek. The site is predominantly open water, but present vegetation is dominated by an exotic, red clover (Trifolium spp.). Rushes, spikerushes (Eleocharis spp.), sedges, beggarticks (Bidens spp.), willow (Salix spp.), and silky dogwood (Cornus amomum) also occur at the site (Fig. 7).

Leading Creek.-This wetland is located in Randolph County, West Virginia, and is described in Balcombe (2003). It was built on both sides of Leading Creek in 1995 by DOH as mitigation for highway construction. The Leading Creek wetland is 8.6 ha, at an elevation of 600 $\mathrm{m}$, and consists of open water ponds, persistent emergent vegetation areas, and wet meadows. The wetland is dominated by common rush, wool grass (Scirpus cyperinus), and cattail (Fig. 8). 
Stauffer's Marsh.-Stauffer's Marsh (named after the property owner) is located along County Road 7 in Berkeley County, West Virginia, just south of Shanghai. This wetland was most likely natural until the early $19^{\text {th }}$ century when it was drained for agriculture. It has since been abandoned and has reverted back to a wetland. The 3.5 ha wetland is at an elevation of 150 $\mathrm{m}$, and is largely open water bordered by cattail (Fig. 9).

Sugar Creek.-The Sugar Creek wetland is located in Barbour County, West Virginia, and is described in Balcombe (2003). It is at an elevation of $478 \mathrm{~m}$, is 6.8 ha, and was built by DOH in 1995 as mitigation for highway construction. Sugar Creek is a combination of open water ponds, scrub-shrub, emergent vegetation, and wet meadows. This wetland is dominated by reed canarygrass bordered by forested stands consisting of laurel oak (Quercus laurifolia), crab apple (Pyrus coronaria), hazelnut (Corylus americana), and hawthorn (Crataegus spp.) (Fig. $10)$.

Upper Deckers Creek WMA.-The wetland at the Upper Deckers Creek Wildlife Management Area in Preston County, West Virginia, was built as mitigation for channelization work done on a portion of Deckers Creek by the Soil Conservation Service (now the Natural Resources Conservation Service). This wetland is at an elevation of $518 \mathrm{~m}$, and although the entire WMA is 8.5 ha in area, this study focused on the northern portion, which is 2.4 ha. It is dominated by open water, and the surrounding vegetation consists mostly of reed canarygrass (Phalaris arundinacea) and cowlily (Nuphar lutea) (Fig. 11). 
VEPCO.-The VEPCO (Virginia Electric Power Company) wetland is located in Tucker County, West Virginia, within the Blackwater River watershed and is described in Balcombe (2003). This wetland was constructed in 1995 as mitigation for a desulfurization facility. It is approximately 7 ha in size, at an elevation of 1,036 m, and consists of four cells separated by dikes. The cells consist of open water and emergent vegetation, predominantly common rush (Fig. 12).

Walnut Bottom.-The Walnut Bottom wetland is located in Hardy County, West Virginia, and is described in Balcombe (2003). It was built in 1997 and is owned by the WV Division of Highways (DOH) as mitigation for highway construction. The wetland is part of the South Branch of the Potomac River and is mainly open water permanent ponds with emergent vegetation. Walnut Bottom is approximately $10 \mathrm{ha}$, at an elevation of $335 \mathrm{~m}$, and is dominated by cattail, spikerush, and reed canarygrass (Fig. 13).

\section{Natural Wetlands}

Camp 70.-The Camp 70 wetland is a historic beaver-induced wetland located along an unnamed tributary to the Blackwater River in the Canaan Valley National Wildlife Refuge, in Tucker County, West Virginia. The wetland is 0.02 ha at an elevation of $952 \mathrm{~m}$, and is located just south of the Camp 70 loop trail (Fig. 14).

Garrett State Forest North.-The Garrett State Forest North wetland is a small scrubshrub wetland that sits along Glade Run in the Garrett State Forest in Garrett County, Maryland. 
This wetland has an elevation of approximately $670 \mathrm{~m}$ and is approximately 2 ha in area. It sits in a forest of predominantly black cherry (Prunus serotina) (Fig. 15).

Garrett State Forest South.-The Garrett State Forest South wetland is located along an unnamed tributary to Herrington Creek, in the Garrett State Forest in Garrett County, Maryland. It is approximately $3.5 \mathrm{~km}$ south of the Garrett State Forest North wetland, and is a historic beaver pond that sits at an elevation of approximately $760 \mathrm{~m}$ and is approximately $2 \mathrm{ha}$ in area. The wetland contains two cells created by two separate beaver dams. The downstream cell is predominantly an open water pond surrounded by a forest of black cherry and red maple (Acer rubrum). The upstream cell is a small scrub-shrub swamp dominated by northern arrowwood (Viburnum recognitum) and sedges (Fig. 16).

Glade Run Beaver Pond.-The Glade Run pond is a historic and active beaver-induced wetland located along Glade Run (a tributary of the Little Blackwater River) in the Canaan Valley National Wildlife Refuge, in Tucker County, West Virginia. The elevation of the wetland is $962 \mathrm{~m}$ and it is 2.0 ha in area. It is dominated by common rush, sedges, wool grass, and silky willow (Salix sericea) (Fig. 17).

Joe Mood.-The Joe Mood wetland (named after the property owner) is located approximately $3 \mathrm{~km}$ from Bruceton Mills in Preston County, West Virginia. The wetland sits at an elevation of $512 \mathrm{~m}$ and is 1.0 ha in area. It is an historic inactive beaver pond and is dominated by reed canarygrass, cattail, and brookside alder (Fig. 18). 
Kempton Swamp.-Kempton Swamp is located in Garrett County, Maryland, although a portion of it extends into West Virginia's Grant County. This wetland is classified in McDonald (1985) as palustrine scrub-shrub broad-leaved deciduous (seasonally flooded-beaver impounded). It is located near the headwaters of the North Branch of the Potomac River and sits at an elevation of $820 \mathrm{~m}$. The vegetation in the wetland consists of shrubs, forbes, grasses, and sedges; a portion of it is also forested. The entire wetland complex is approximately $33 \mathrm{ha}$, but my study focused on the 3.5 ha northwestern portion (Fig. 19).

Muddlety.-The Muddlety wetland is located in Nicholas County, West Virginia, just off of U.S. Route 19 north of Summersville, and is described in Balcombe (2003). This wetland is a semi-permanently flooded to permanently flooded complex situated along Muddlety Creek at an elevation of $590 \mathrm{~m}$ and 7.0 ha in area. The shrub thickets portions of the wetland consist of swamp rose (Rosa palustris) and silky dogwood, and the emergent vegetation portions consist of burreed and cattail (Fig. 20)

Old Fields.-The Old Fields wetland is approximately $10 \mathrm{~km}$ northeast of the Walnut Bottom mitigated wetland and is situated along an unnamed tributary to Anderson Run in Hardy County, West Virginia. This wetland sits amid two agricultural plots at an elevation of $292 \mathrm{~m}$ and is 4.0 ha in area. The very southern portion of the wetland is occasionally grazed by cattle and was therefore excluded from this study. The dominant vegetation at this site is cattail, reed canarygrass, and sedges (Fig. 21). 
Rail Trail North.-The Rail Trail North wetland is a floodplain wetland of Deckers Creek which lies along the West Virginia Rail Trail north of the intersection of the trail and Route 92, just south of Reedsville in Preston County, West Virginia. This scrub-shrub (predominantly buttonbush, Cephalanthus occidentalis) wetland is 4.7 ha in area, and sits at an elevation of 515 m (Fig. 22).

Rail Trail South.-The Rail Trail South wetland lies along the West Virginia Rail Trail south of the intersection of the trail and Route 92, just south of Reedsville in Preston County, West Virginia. It is situated along Kanes Creek, a tributary of Deckers Creek, at an elevation of $525 \mathrm{~m}$. This wetland is predominantly forested, is $4.1 \mathrm{ha}$ in area, and lies approximately $1 \mathrm{~km}$ from the Rail Trail North wetland (Fig. 23).

Short Mountain.-The Short Mountain wetland is located in Hampshire County, West Virginia, in the Short Mountain Wildlife Management Area and is described in McDonald (1985). This property is owned by the West Virginia Division of Natural Resources (WVDNR) and is used as a public hunting and camping area. The wetland is part of Meadow Creek and is classified as a palustrine emergent nonpersistent (permanently flooded to saturated-beaver impounded) wetland. The wetland is approximately $43 \mathrm{ha}$, at an elevation of $625 \mathrm{~m}$, and is dominated by sedges, grasses, mosses, alders (Alnus spp.), and heath shrubs. For this study, I focused on a large beaver pond (3.8 ha) in the southern portion of the site (Fig. 24).

Upper Deckers Creek.-The Upper Deckers Creek wetland is located outside of Masontown in Preston County, West Virginia, and is an oxbow wetland of Deckers Creek at an 
elevation of approximately $512 \mathrm{~m}$. This wetland is 2.6 ha in area and consists of aquatic bed, emergent persistent, and scrub-shrub classes, and is dominated by reed canarygrass, cowlily, marsh purslane (Lugwigia palustris), and buttonbush (Fig. 25).

\section{Literature Cited}

Abernethy, Y., and R.E. Turner. 1987. U.S. forested wetlands: 1940-1980. BioScience $37: 721-727$.

Ainslie, W.B. 1994. Rapid wetland functional assessment: its role and utility in the regulatory arena. Water, Air and Soil Pollution 77:433-444.

Alford, R.A., and S.J. Richards. 1999. Global amphibian declines: a problem in applied ecology. Annual Review of Ecology and Systematics 30:133-165.

Allen, A.O., and J.J. Feddema. 1996. Wetland loss and substitution by the Section 404 permit program in southern California, USA. Environmental Management 20:263-274.

Anderson, J.T., L.M. Smith, and D.A. Haukos. 2000. Food selection and feather molt by nonbreeding American green-winged teal in Texas playas. Journal of Wildlife Management 64:222-230.

Atkinson, R.B., and J. Cairns, Jr. 2001. Plant decomposition and litter accumulation in depressional wetlands: functional performance of two wetland age classes that were created via excavation. Wetlands 21:354-362.

Atkinson, R.B., J.E. Perry, and J. Cairns, Jr. 2005. Vegetation communities of 20-yearold created depressional wetlands. Wetlands Ecology and Management 13:469-478.

Bailey, R.W. 1954. Status of beavers in West Virginia. Journal of Wildlife Management 18:184-190. 
Balcombe, C.K. 2003. An evaluation of vegetation and wildlife communities in mitigation and natural wetlands of West Virginia. Thesis, West Virginia University, Morgantown, WV.

Balcombe, C.K., J.T. Anderson, R.H. Fortney, and W.S. Kordek. 2005a. Wildlife use of mitigation and reference wetlands in West Virginia. Ecological Engineering 25:85-99.

Balcombe, C.K., J.T. Anderson, R.H. Fortney, J.S. Rentch, W.N. Grafton, and W.S. Kordek. 2005b. A comparison of plant communities in mitigation and reference wetlands in the mid-Appalachians. Wetlands 25:130-142.

Balcombe, C.K., J.T. Anderson, R.H. Fortney, and W.S. Kordek. 2005c. Vegetation, invertebrate, and wildlife community rankings and habitat analysis of mitigation wetlands in West Virginia. Wetlands Ecology and Management 13:517-530.

Balcombe, C.K., J.T. Anderson, R.H. Fortney, and W.S. Kordek. 2005d. Aquatic macroinvertebrate assemblages in mitigated and natural wetlands. Hydrobiologia $541: 175-188$.

Bartoldus, C.C. 1994. EPW: a procedure for the functional assessment of planned wetlands. Water, Air, and Soil Pollution 77:533-541.

Batzer, D.P., C.R. Jackson, and M. Mosner. 2000. Influences of riparian logging on plants and invertebrates in small, depressional wetlands of Georgia, USA. Hydrobiologia 441:123-132.

Batzer, D.P., and S.A. Wissinger. 1996. Ecology of insect communities in nontidal wetlands. Annual Review of Entomology 41:75-100.

Bedford, B.L. 1996. The need to define hydrologic equivalence at the landscape scale for freshwater wetland mitigation. Ecological Applications 6:57-68. 
Bedford, B.L., and K.S. Godwin. 2003. Fens of the United States: distribution, characteristics, and scientific connection versus legal isolation. Wetlands 23:608-629.

Berven, K.A., and T.A. Grudzien. 1990. Dispersal in the wood frog (Rana sylvatica): implications for genetic population structure. Evolution 44:2047-2056.

Blackwell, M.S.A., and E.S. Pilgrim. 2011. Ecosystem services delivered by small-scale wetlands. Hydrological Sciences Journal 56:1467-1484.

Blaustein, A.R., D.B. Wake, and W.P. Sousa. 1994. Amphibian declines: judging stability, persistence, and susceptibility of populations to local and global extinctions. Conservation Biology 8:60-71.

Bonner, J.L., J.T. Anderson, J.S. Rentch, and W.N. Grafton. 2009. Vegetative composition and community structure associated with beaver ponds in Canaan Valley, West Virginia, USA. Wetlands Ecology and Management 17:543-554.

Brinson, M.M., and A.I. Malvarez. 2002. Temperate freshwater wetlands: types, status, and threats. Environmental Conservation 29:115-133.

Brinson, M.M., and R. Rheinhardt. 1996. The role of reference wetlands in functional assessment and mitigation. Ecological Applications 6:69-76.

Bronmark, C., and P. Edenhamm. 1994. Does the presence of fish affect the distribution of tree frogs (Hyla arborea)? Conservation Biology 8:841-845.

Brown, S.C., and P.L.M. Veneman. 2001. Effectiveness of compensatory wetland mitigation in Massachusetts, USA. Wetlands 21:508-518.

Byers, E.A., J.P. Vanderhorst, and B.P. Streets. 2007. Classification and conservation 
assessment of high elevation wetlands communities in the Allegheny Mountains of West Virginia. West Virginia Natural Heritage Program, West Virginia Division of Natural Resources, Elkins, WV.

Campbell, D.A., C.A. Cole, and R.P. Brooks. 2002. A comparison of created and natural wetlands in Pennsylvania, USA. Wetlands Ecology and Management 10:41-49.

Christie, J., and S. Hausmann. 2003. Various state reactions to the SWANCC decision. Wetlands 23:653-662.

Cole, C.A., and R.P. Brooks. 2000. A comparison of the hydrologic characteristics of natural and created mainstem floodplain wetlands in Pennsylvania. Ecological Engineering 14:221-231.

Cole, C.A., and D. Shafer. 2002. Section 404 wetland mitigation and permit success criteria in Pennsylvania, USA, 1986-1999. Environmental Management 30:508-515.

Copeland, C. 2010. Wetlands: an overview of issues. Congressional Research Service Reports, Paper 37.

Cunningham, J.M. 2003. Pond-breeding amphibian distributions in a beaver-modified landscape, Acadia National Park, Mount Desert Island, Maine. Thesis, University of Maine, Orono, ME.

Cunningham, J.M., A.J.K. Calhoun, and W.E. Glanz. 2006. Patterns of beaver colonization and wetland change in Acadia National Park. Northeastern Naturalist 13:583-596.

Dahl, T.E. 1990 . Wetlands losses in the United States 1780 's to 1980 's. U.S. Department of the Interior, Fish and Wildlife Service, Washington, D.C.

Dahl, T.E. 2006. Status and trends of wetlands in the conterminous United States 1998 to 
2004. U.S. Department of the Interior, Fish and Wildlife Service, Washington,

D.C.

Dahl, T.E. 2011. Status and trends of wetlands in the conterminous United States 2004 to 2009.

U.S. Department of the Interior, Fish and Wildlife Service, Washington, D.C.

Dahl, T.E., and C.E. Johnson. 1991. Status and trends of wetlands in the conterminous United States, mid-1970’s to mid-1980’s. U.S. Department of the Interior, Fish and Wildlife Service, Washington, D.C.

Davic, R.D., and H.H. Welsh, Jr. 2004. On the ecological role of salamanders. Annual Review of Ecology, Evolution, and Systematics 35:405-434.

DeBerry, D.A., and J.E. Perry. 2004. Primary succession in a created freshwater wetland. Castanea 69:185-193.

DeLaune, R.D., and J.R. White. 2012. Will coastal wetlands continue to sequester carbon in response to an increase in global sea level?: a case study of the rapidly subsiding Mississippi river deltaic plain. Climatic Change 110:297-314.

Duellman, W.E., and L. Trueb. 1994. Biology of amphibians. The John Hopkins University Press, Baltimore, MD.

Enge, K.M., and W.R. Marion. 1986. Effects of clearcutting and site preparation on herpetofauna of a north Florida flatwoods. Forest Ecology and Management 14:177-192.

Environmental Laboratory. 1987. Corps of Engineers wetlands delineation manual. Technical Report Y-87-1, U.S. Army Engineer Waterways Experimental Station, Vicksburg, MS.

Ferrell, G.M. 1982. Historical analysis of wetlands on the floodplain of the Kanawha 
River of West Virginia. Pages 65-68 in B.R. McDonald (Ed.). Proceedings of the symposium on wetlands of the unglaciated Appalachian region. West Virginia University, Morgantown WV.

Flite, O.P., III, R.D. Shannon, R.R. Schnabel, R.R. Parizek. 2001. Nitrate removal in a riparian wetland of the Appalachian Valley and Ridge physiographic province. Journal of Environmental Quality 30:254-261.

Francl, K.E., and S.B. Castleberry. 2004. Small mammal communities of high elevation central Appalachian wetlands. American Midland Naturalist 151:388-398.

Francl, K.E., W.M. Ford, and S.B. Castleberry. 2004. Characterization of high elevation central Appalachian wetlands. Research Paper NE-725. U.S. Department of Agriculture, Forest Service, Northeastern Research Station, Newtown Square, PA.

Ghermandi, A., J.C.J.M. van den Bergh, L.M. Brander, H.L.F. de Groot, and P.A.L.D. Nunes. 2010. Values of natural and human-made wetlands: a meta-analysis. Water Resources Research 46:W12516, doi:10.1029/2010WR009071.

Gibbons, J.W. 2003. Terrestrial habitat: a vital component for herpetofauna of isolated wetlands. Wetlands 23:630-635.

Gibbs, J.P. 2000. Wetland loss and biodiversity conservation. Conservation Biology $14: 314-317$.

Gingerich, R.T., and J.T. Anderson. 2011. Decomposition trends of five plant litter types in mitigated and reference wetlands in West Virginia, USA. Wetlands 31:653-662.

Hill, P.L., and J.R. Taylor. 1982. Ecosystem dynamics and impact of highway construction on 
Greenbottom Swamp, Cabell County, West Virginia, USA. Pages 69-73 in B.R. McDonald (Ed.). Proceedings of the symposium on wetlands of the unglaciated Appalachian region. West Virginia University, Morgantown WV.

Hodkinson, I.D. 1975. A community analysis of the benthic insect fauna of an abandoned beaver pond. Journal of Animal Ecology 44:533-551.

Hopey, M.E., and J.W. Petranka. 1994. Restriction of wood frogs to fish-free habitats: how important is adult choice? Copeia 1994:1023-1025.

Hossler, K., V. Bouchard, M.S. Fennessy, S.D. Frey, E. Anemaet, and E. Herbert. 2011. No-netloss not met for nutrient function in freshwater marshes: recommendations for wetland mitigation policies. Ecosphere 2:1-36.

Houlahan, J.E., and C.S. Findlay. 2003. The effects of adjacent land use on wetland amphibian species richness and community composition. Canadian Journal of Fisheries and Aquatic Sciences 60:1078-1094.

Jones, C.G., J.H. Lawton, and M. Shachak. 1994. Organisms as ecosystem engineers. Oikos 69:373-386.

Knutson, M.G., W.B. Richardson, D.M. Reineke, B.R. Gray, J.R. Parmelee, and S.E. Weick. 2004. Agricultural ponds support amphibian populations. Ecological Applications 14:669-684.

Korfel, C.A, W.J. Mitsch, T.E. Hetheringon, and J.J. Mack. 2010. Hydrology, physiochemistry, and amphibians in natural and created vernal pool wetlands. Restoration Ecology 18:843854.

Lamoureux, V.S., and D.M. Madison. 1999. Overwintering habitats of radio-implanted green frogs, Rana clamitans. Journal of Herpetology 33:430-435. 
Lehtinen, R.M., S.M. Galatowitsch, and J.R. Tester. 1999. Consequences of habitat loss and fragmentation for wetland amphibian assemblages. Wetlands 19:1-12.

Lehtinen, R.M., and S.M. Galatowitsch. 2001. Colonization of restored wetlands by amphibians in Minnesota. American Midland Naturalist 145:388-396.

Lincoln, R., G. Boxshall, and P. Clark. 1998. A dictionary of ecology, evolution and systematic. $2^{\text {nd }}$ ed. Cambridge University Press, Cambridge, UK.

Madison, D.M. 1997. The emigration of radio-implanted spotted salamanders, Ambystoma maculatum. Journal of Herpetology 31:542-551.

Maerz, J.C., J.S. Cohen, and B. Blossey. 2010. Does detritus quality predict the effect of native and nonnative plants on the performance of larval amphibians? Freshwater Biology 55:1694-1704.

Margolis, B.E., M.S. Castro, and R.L. Raesly. 2001a. The impact of beaver impoundments on the water chemistry of two Appalachian streams. Canadian Journal of Fisheries and Aquatic Science 58:2271-2283.

Margolis, B.E., R.L. Raesly, and D.L. Shumway. 2001b. The effects of beaver-created wetlands on the benthic macroinvertebrate assemblages of two Appalachian streams. Wetlands 21:554-563.

Marsh, D.M., and P.C. Trenham. 2001. Metapopulation dynamics and amphibian conservation. Conservation Biology 15:40-49.

Mazumder, D., N. Saintilan, R.J. Williams, and R. Szymczak. 2011. Trophic importance of a temperate intertidal wetland to resident and itinerant taxa: evidence from multiple stable isotope analyses. Marine and Freshwater Research 62:11-19.

McCauley, L.A., and D.G. Jenkins. 2005. GIS-based estimates of former and current 
depressional wetlands in an agricultural landscape. Ecological Applications 15:11991208.

McCuskey, S.A., A.W. Conger, and H.O. Hillestad. 1994. Design and implementation of functional wetland mitigation: case studies in Ohio and South Carolina. Water, Air and Soil Pollution 77:513-532.

McDonald, B.R. 1985. Wetlands of West Virginia: location and classification. West Virginia Department of Natural Resources, Wildlife Resources Division, Wildlife and Natural Heritage Data Base, Elkins, WV.

Micacchion, M. 2002. Amphibian index of biotic integrity (AmphIBI) for wetlands. Final report to U.S. EPA Grant No. CD985875-01. Ohio Environmental Protection Agency. Wetland Ecology Group, Division of Surface Water, Columbus, OH.

Mitsch, W.J., and J.G. Gosselink. 1993. Wetlands, $2^{\text {nd }}$ edition. Wiley and Sons, New York, NY.

Mitsch, W.J., and R.F. Wilson. 1996. Improving the success of wetland creation and restoration with know-how, time, and self-design. Ecological Applications 6:77-83.

Mitsch, W.J., X. Wu, R.W. Nairn, P.E. Weihe, N. Wang, R. Deal, and C.E. Boucher. 1998. Creating and restoring wetlands. BioScience 48:1019-1030.

Moreno-Mateos D., M.E. Power, F.A. Comin, and R. Yockteng. 2012. Structural and functional loss in restored wetland ecosystems. PLOS Biology 10: e1001247. doi:10.1371/journal.pbio.1001247

Murdock, N.A. 1994. Rare and endangered plants and animals of southern Appalachian wetlands. Water, Air and Soil Pollution 77:385-405.

Naiman, R.J., C.A. Johnston, and J.C. Kelley. 1988. Alteration of North American 
streams by beaver. BioScience 38:753-762.

National Research Council. 2001. Compensating for wetland losses under the Clean Water Act. National Academy Press, Washington D.C.

Paton, P.W.C, and W.B. Crouch III. 2002. Using the phenology of pond-breeding amphibians to develop conservation strategies. Conservation Biology 16:194-204.

Pauley, T.K.. 2000. Amphibians and reptiles in wetland habitats of West Virginia. Proceedings of the West Virginia Academy of Sciences 72:78-88.

Pechmann, J.H.K., R.A. Estes, D.E. Scott, and J.W. Gibbons. 2001. Amphibian colonization and use of ponds created for trial mitigation of wetland loss. Wetlands 21:93-111.

Pechmann, J.H.K., D.E. Scott, J.W. Gibbons, and R.D. Semlitsch. 1989. Influence of wetland hydroperiod on diversity and abundance of metamorphosing juvenile amphibians. Wetlands Ecology and Management 1:3-11.

Petranka, J.W., and C.T. Holbrook. 2006. Wetland restoration for amphibians: should local sites be designed to support metapopulations or patchy populations? Restoration Ecology 14:404-411.

Petranka, J.W., M.E. Hopey, B.T. Jennings, S.D. Baird, and S.J. Boone. 1994. Breeding habitat segregation of wood frogs and American toads: the role of interspecific tadpole predation and adult choice. Copeia 1994:691-697.

Petranka, J.W., and C.A. Kennedy. 1999. Pond tadpoles with generalized morphology: is it time to reconsider their functional roles in aquatic communities? Oecologia 120:621631.

Petranka, J.W., C.A. Kennedy, and S.S. Murray. 2003a. Response of amphibians to 
restoration of a southern Appalachian wetland: a long-term analysis of community dynamics. Wetlands 23:1030-1042.

Petranka, J.W., S.S. Murray, and C.A. Kennedy. 2003b. Responses of amphibians to restoration of a southern Appalachian wetland: perturbations confound post-restoration assessment. Wetlands 23:278-290.

Phillips, K. 1990. Where have all the frogs and toads gone? BioScience 40:422-424.

Pope, S.E., L. Fahrig, and H.G. Merriam. 2000. Landscape complementation and metapopulation effects on leopard frog populations. Ecology 81:2498-2508.

Race, M.S., and M.S. Fonseca. 1996. Fixing compensatory mitigation: what will it take? Ecological Applications 6:94-101.

Rentch, J.S., J.T. Anderson, S. Lamont, J. Sencindiver, and R. Eli. 2008. Vegetation along hydrologic, edaphic, and geochemical gradients in a high-elevation poor fen in Canaan Valley, West Virginia. Wetlands Ecology and Management 16:237-253.

Robb, J.T. 2002. Assessing wetland compensatory mitigation sites to aid in establishing mitigation ratios. Wetlands 22:435-440.

Rossell, I.M., and C.L. Wells. 1999. The seed banks of a southern Appalachian fen and an adjacent degraded wetland. Wetlands 19:365-371.

Rubbo, M.J., J.L. Lanterman, R.C. Falco, and T.J. Daniels. 2011. The influence of amphibians on mosquitoes in seasonal pools: can wetlands protection help to minimize disease risk? Wetlands 31:799-804.

Ruiz, A.M., J.C. Maerz, A.K. Davis, M. Kevinkeel, A.R. Ferreira, M.J. Conroy, L.A. Morris, and 
A.T. Fisk. 2010. Patterns of development and abnormalities among tadpoles in a constructed wetland receiving treated wastewater. Environmental Science and Technology 44:4862-4868.

Seale, D.B. 1980. Influence of amphibian larvae on primary production, nutrient flux, and competition in a pond ecosystem. Ecology 61:1531-1550.

Scatolini, S.R., and J.B. Zedler. 1996. Epibenthic invertebrates of natural and constructed marshes of San Diego Bay. Wetlands 16:24-37.

Semlitsch, R.D., and J.R. Bodie. 1998. Are small, isolated wetlands expendable? Conservation Biology 12:1129-1133.

Shulse, C.D., R.D. Semlitsch, K.M. Trauth, and A.D. Williams. 2010. Influences of design and landscape placement parameters on amphibian abundance in constructed wetlands. Wetlands 30:915-928.

Skelly, D.K., L.K. Freidenburg, and J.M. Kiesecker. 2002. Forest canopy and the performance of larval amphibians. Ecology 83:983-992.

Smith, L.M., M.J. Gray, and A. Quarles. 2004. Diets of newly metamorphosed amphibians in west Texas playas. The Southwestern Naturalist 49:257-263.

Smith, L.S., and E.D. Michael. 1982. Values of wetlands in the unglaciated Appalachian region. Pages 239-253 in B.R. McDonald (Ed.). Proceedings of the symposium on wetlands of the unglaciated Appalachian region. West Virginia University, Morgantown WV.

Snodgrass, J.W., M.J. Komoroski, A.L. Bryan, Jr., and J. Burger. 2000. Relationships among isolated wetland size, hydroperiod, and amphibian species richness: implications for wetland regulations. Conservation Biology 14:414-419. 
Spieles, D.J., M. Coneybeer, and J. Horn. 2006. Community structure and quality after 10 years in two central Ohio mitigation bank wetlands. Environmental Management 38:837852.

Steketee, A.K. 2000. Predicting habitat suitability for American woodcock and landscape-level assessment of habitat in West Virginia. Dissertation, West Virginia University, Morgantown, WV.

Sutton-Grier, A.E., M.A. Kenney, and C.J. Richardson. 2011. Examining the relationship between ecosystem structure and function using structural equation modelling: a case study examining denitrification potential in restored wetland soils. Ecological Modelling 221:761-768.

Tiner, R.W. 2002. In search of swampland. A wetlands sourcebook and field guide. Rutgers University Press, New Brunswick, NJ.

Tousignant, M., S. Pellerin, and J. Brisson. 2010. The relative impact of human disturbances on the vegetation of a large wetland complex. Wetlands 30:333-344.

Turner, R.E., A.M. Redmond, and J.B. Zedler. 2001. Count it up by acre or function mitigation adds up to net loss of wetlands. National Wetlands Newsletter 23:5-16.

Veysey, J.S., S.D. Mattfeldt, and K.J. Babbitt. 2011. Comparative influence of isolation, landscape, and wetland characteristics on egg-mass abundance of two pool-breeding amphibian species. Landscape Ecology 26:661-672.

Webb, L.O., and D.E. Samuel. 1982. Woodcock habitat inventory and wetlands in northern West Virginia. Pages 175-188 in B.R. McDonald (Ed.). Proceedings of the symposium on wetlands of the unglaciated Appalachian region. West Virginia University, Morgantown WV. 
Weller, MW. 1999. Wetlands birds: habitat resources and conservation implications. Cambridge University Press, Cambridge, NY.

Whigham, D.F. 1999. Ecological issues related to wetland preservation, restoration, creation and assessment. The Science of the Total Environment 240:31-40.

White, P.S., and J.L. Walker. 1997. Approximating nature's variation: selecting and using reference information in restoration ecology. Restoration Ecology 5:338-349.

Wilbur, H.M. 1972. Competition, predation, and the structure of the Ambystoma - Rana sylvatica community. Ecology 53:3-21.

Wilson, R.F., and W.J. Mitsch. 1996. Functional assessment of five wetlands constructed to mitigate wetlands loss in Ohio, USA. Wetlands 16:436-451.

Zedler, J.B. 1996. Ecological issues in wetland mitigation: an introduction to the forum. Ecological Applications 6:33-37.

Zedler, J.B., and J.C. Callaway. 1999. Tracking wetland restoration: do mitigation sites follow desired trajectories? Restoration Ecology 7:69-73.

Zimmer, K.D., M.A. Hanson, and M.G. Butler. 2000. Factors influencing invertebrate communities in prairie wetlands: a multivariate approach. Canadian Journal of Fisheries and Aquatic Science 57:76-85. 


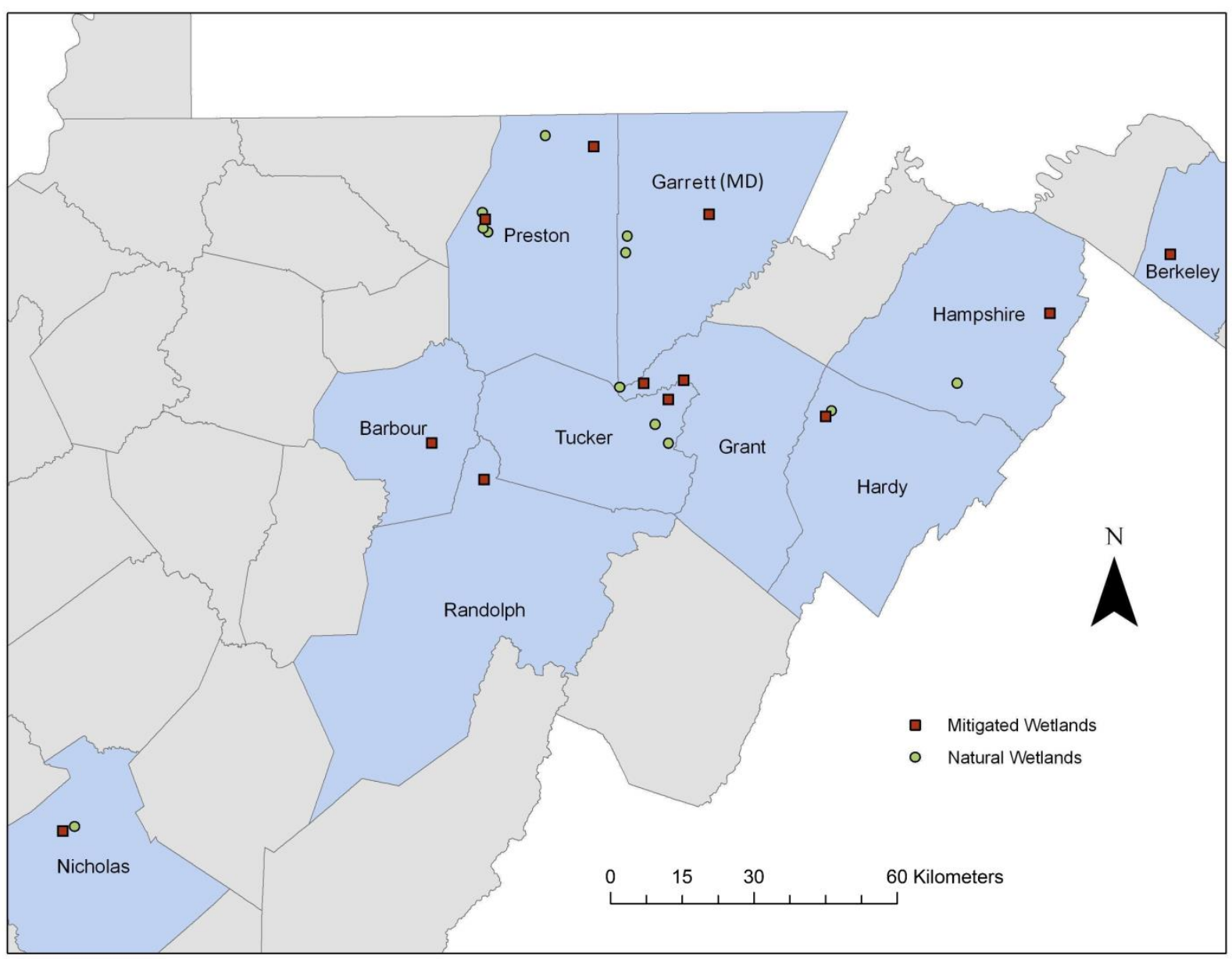

Figure 1. Locations of study sites in West Virginia and Garrett County, Maryland. 


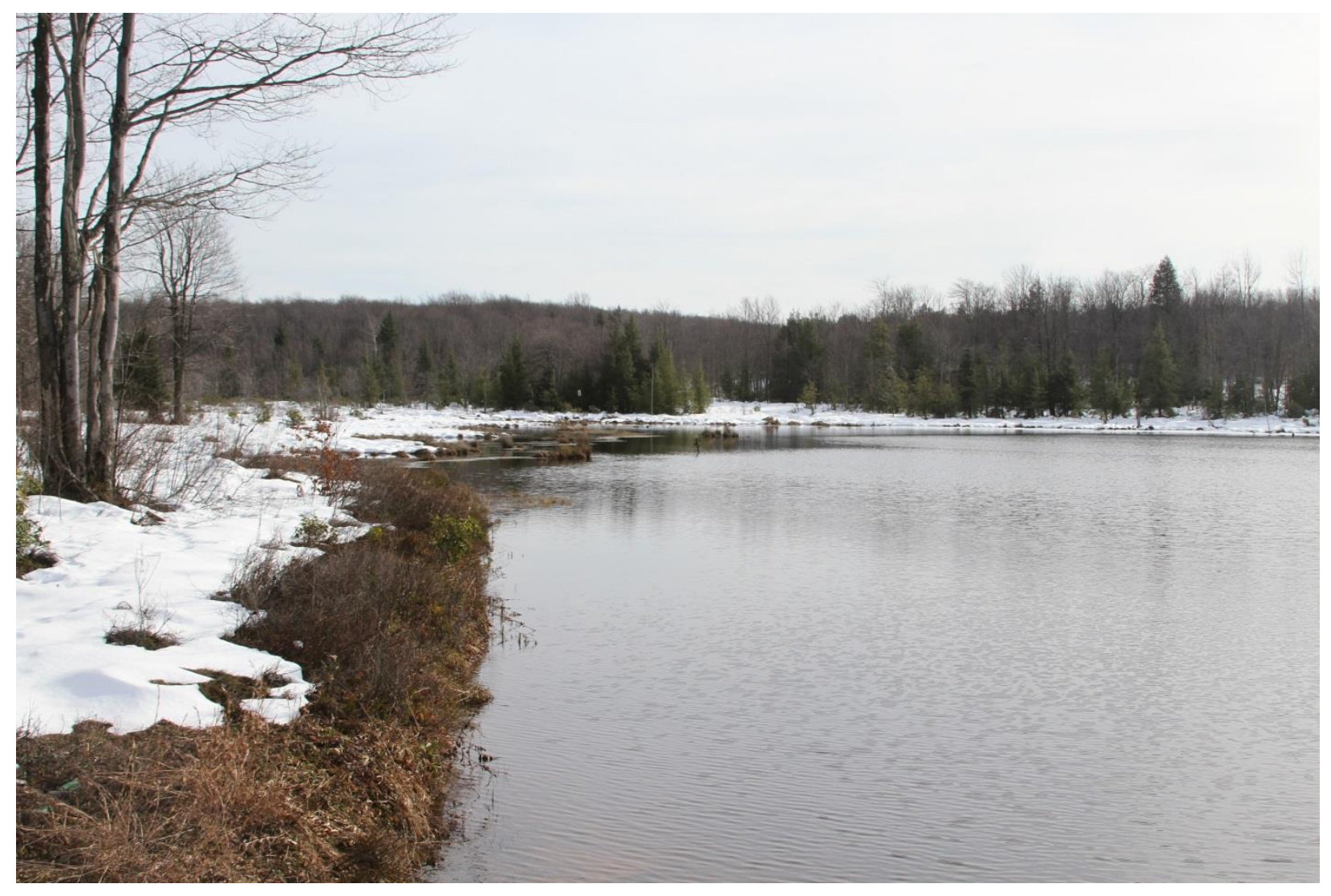

Figure 2. Photograph of Buffalo Coal 2, a created wetland in Grant County, West Virginia, 2010. 


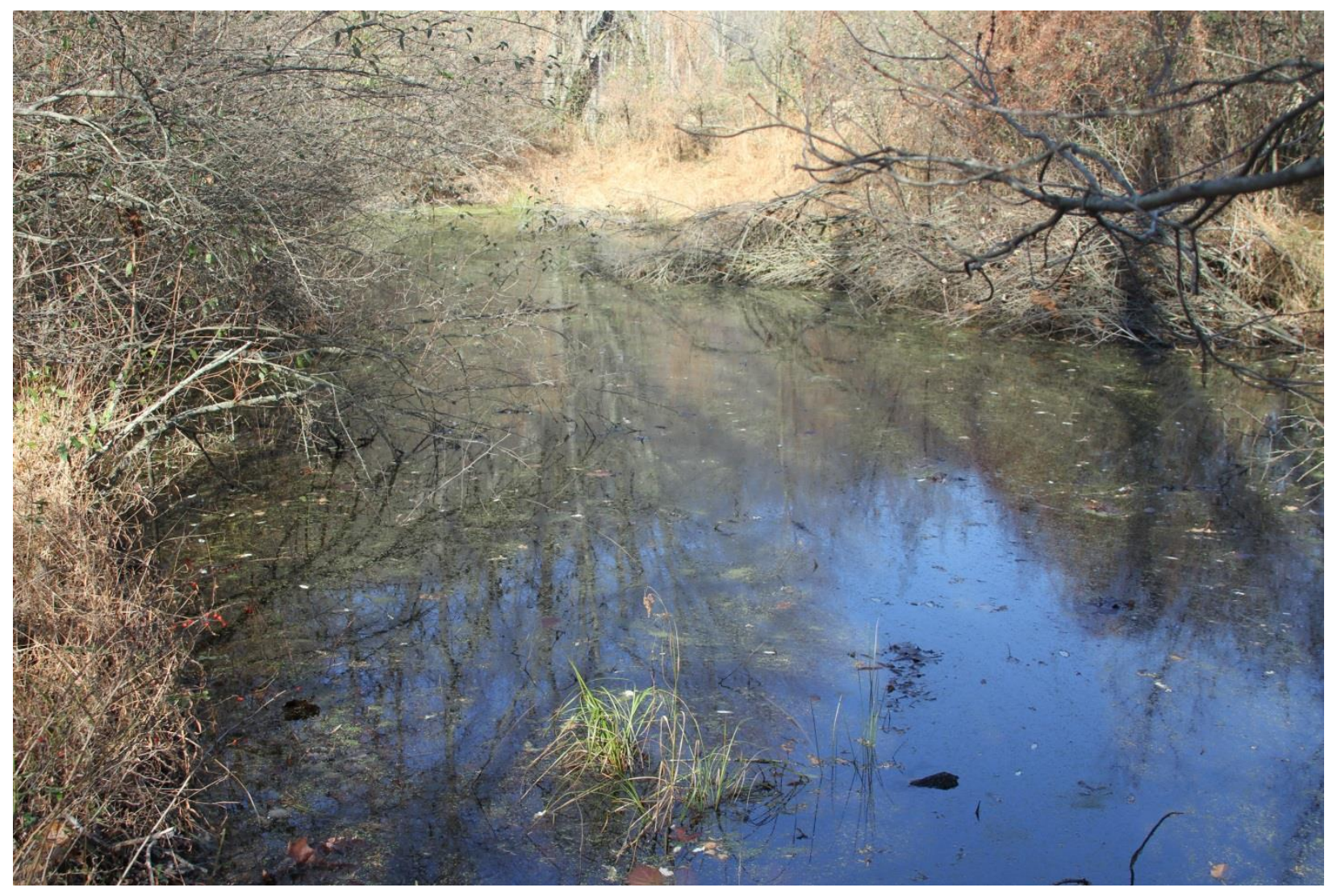

Figure 3. Photograph of Edward's Run, a created wetland in Hampshire County, West Virginia, 2010. 


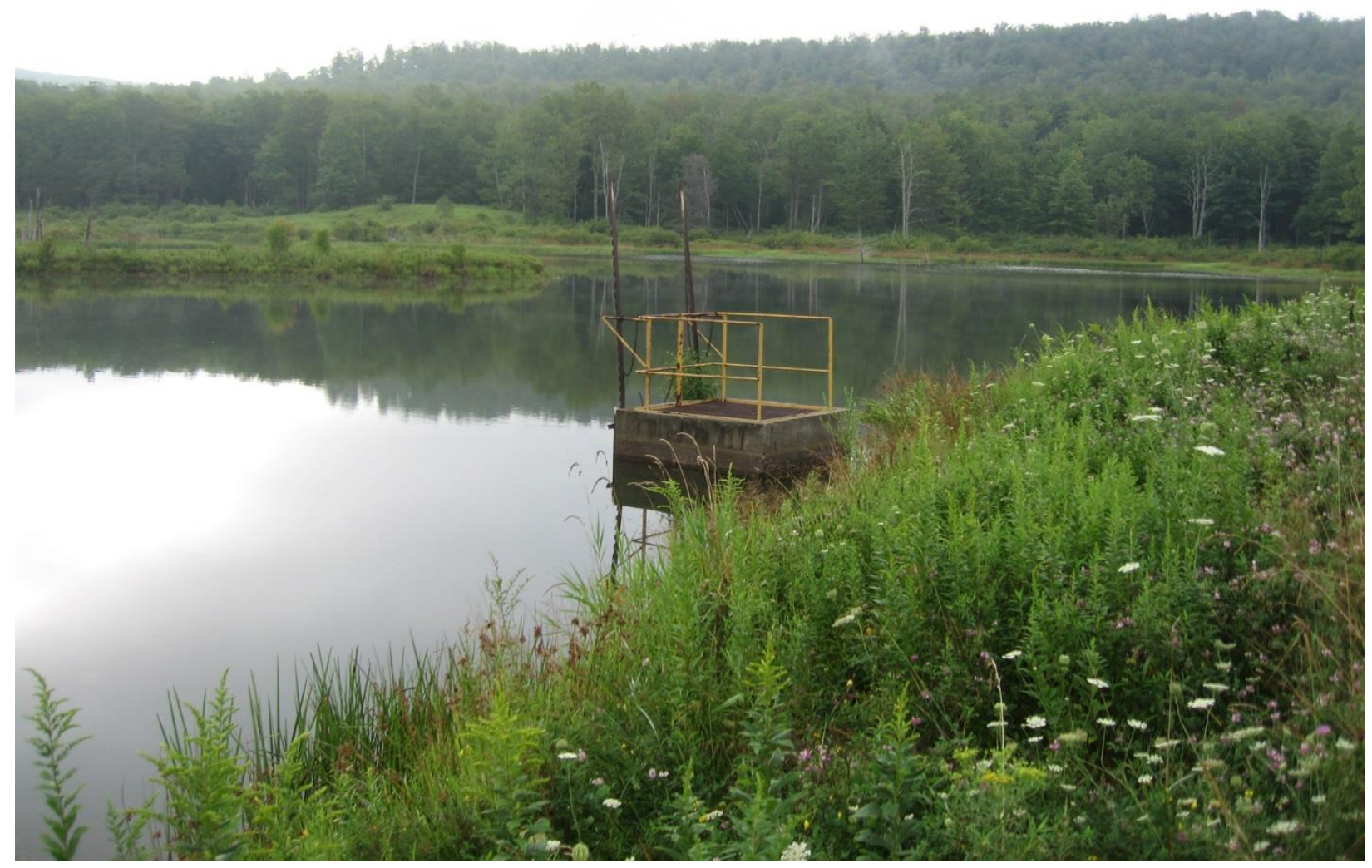

Figure 4. Photograph of Elk Run, a created wetland in Grant County, West Virginia, 2010. 


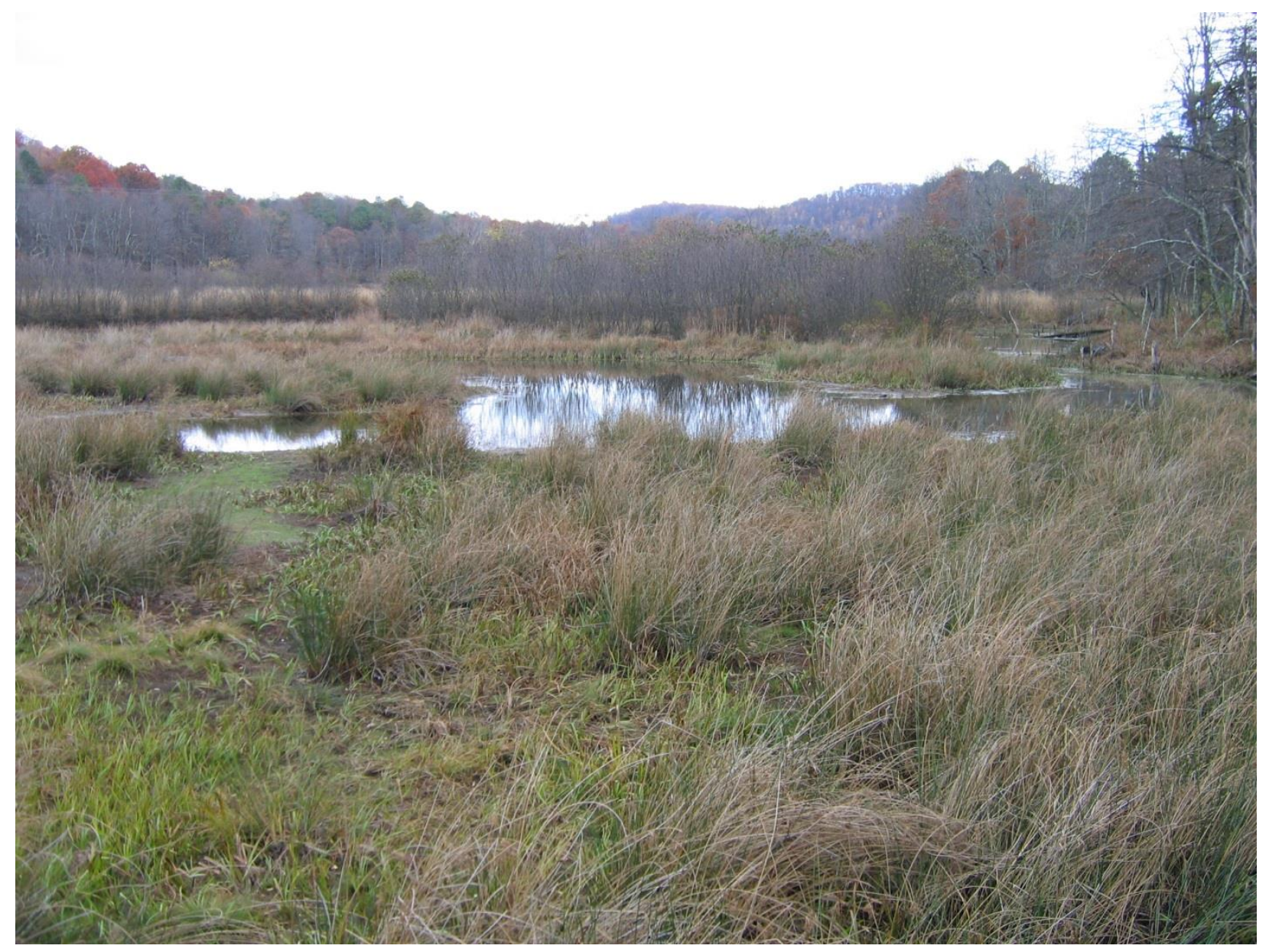

Figure 5. Photograph of Enoch Branch, a created wetland in Nicholas County, West Virginia, 2010. 


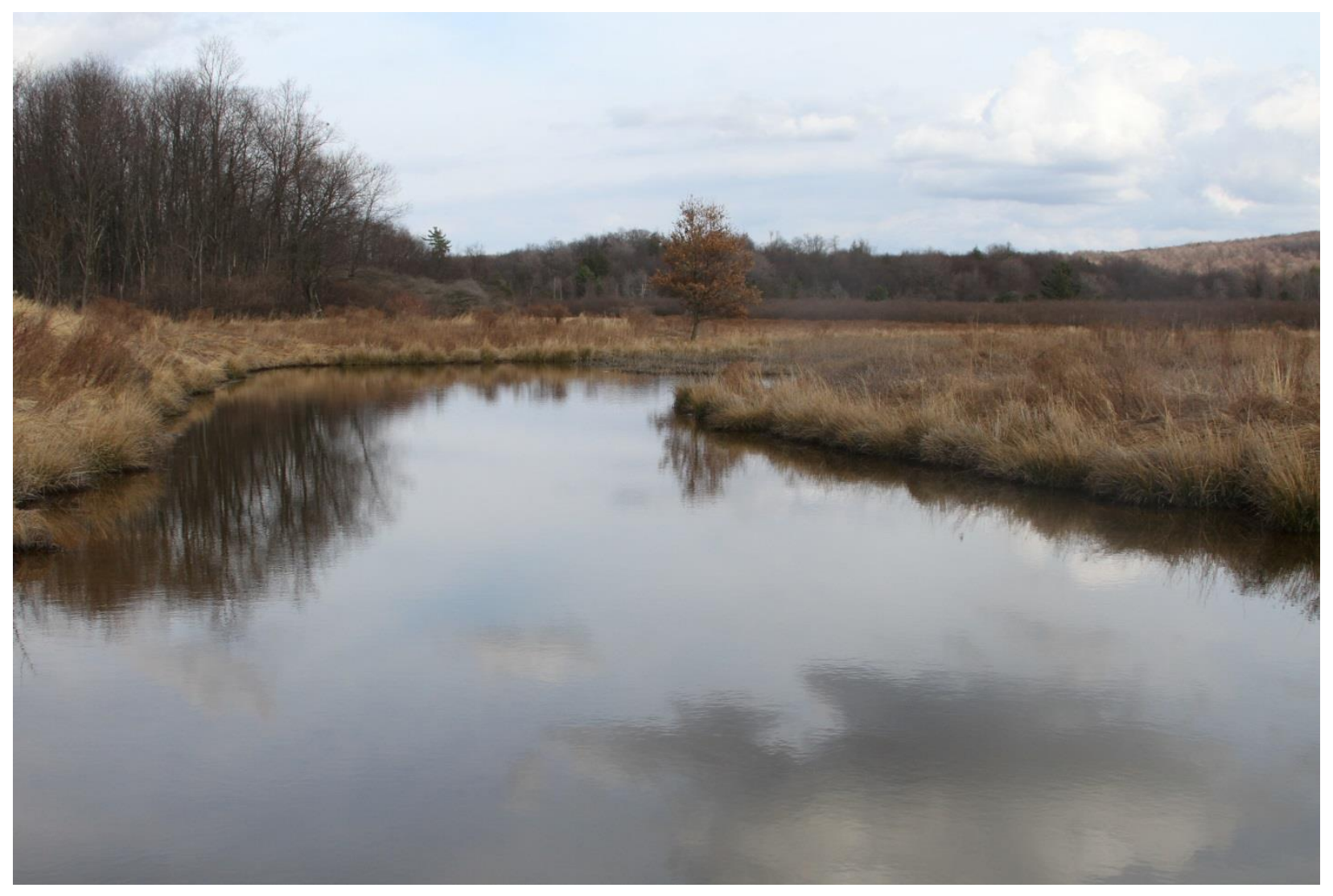

Figure 6. Photograph of Everhart Seep, a created wetland in Garrett County, Maryland, 2010. 


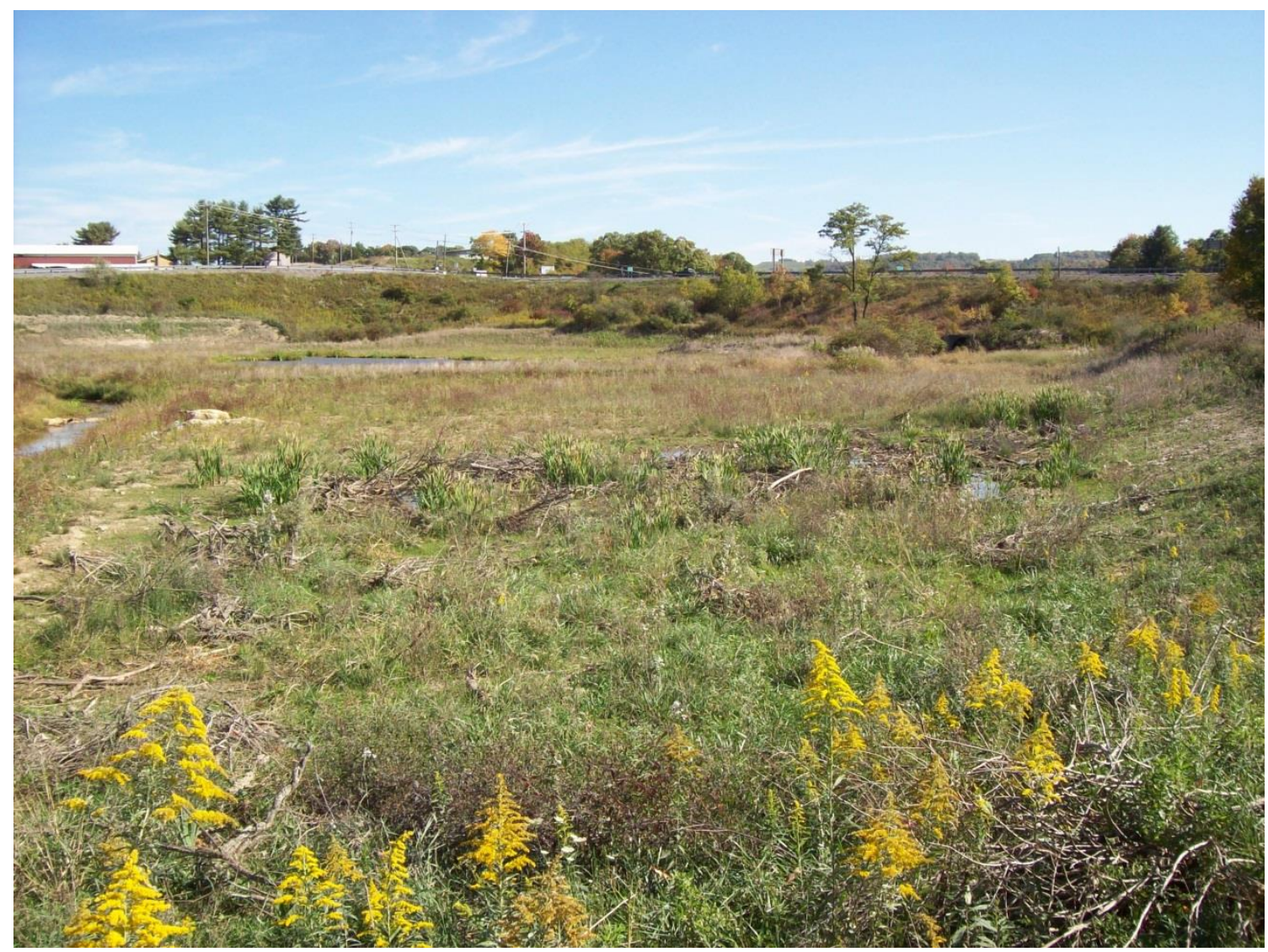

Figure 7. Photograph of Hazelton, a created wetland in Preston County, West Virginia, 2010. 


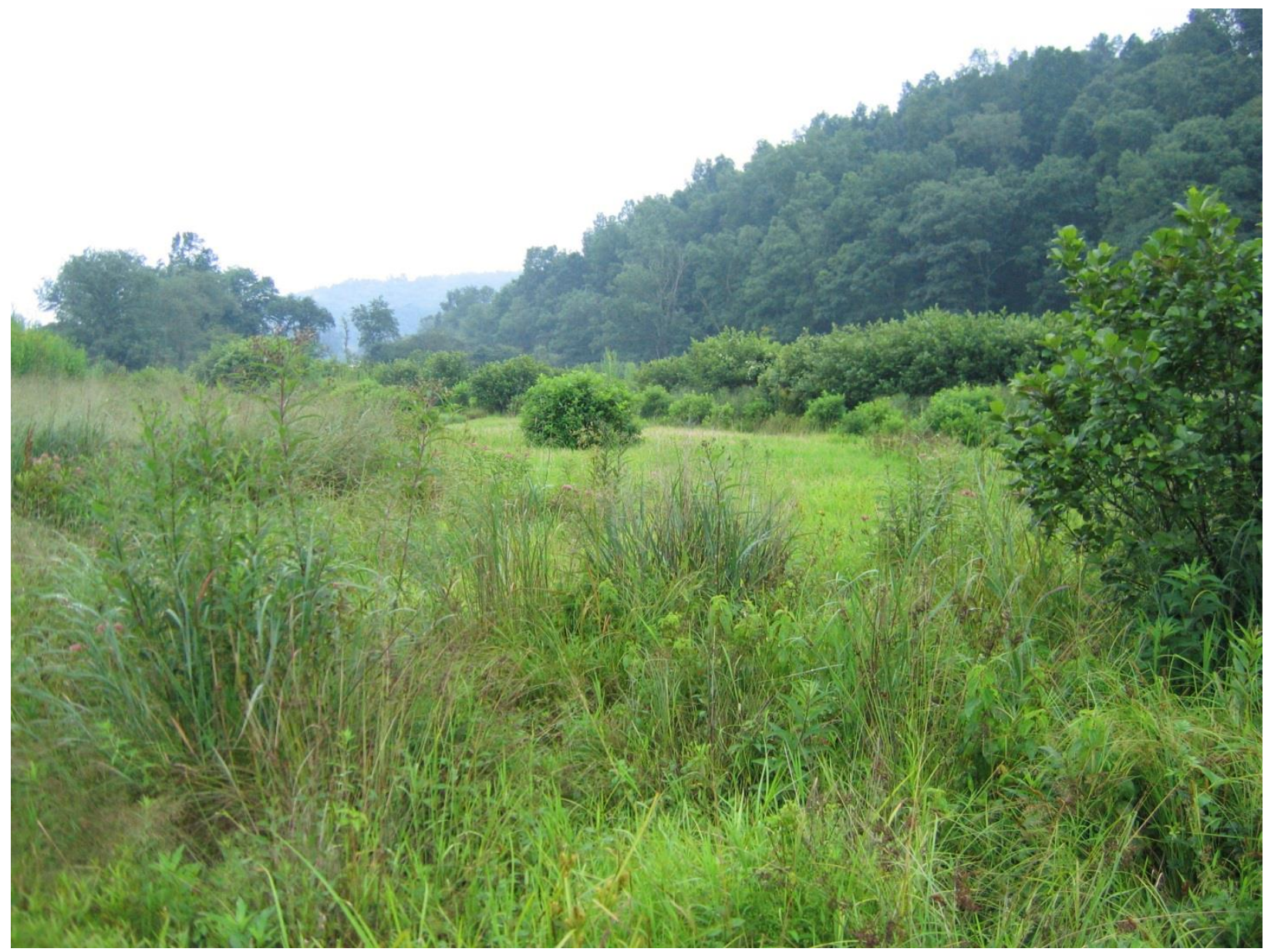

Figure 8. Photograph of Leading Creek, a created wetland in Randolph County, West Virginia, 2010. 


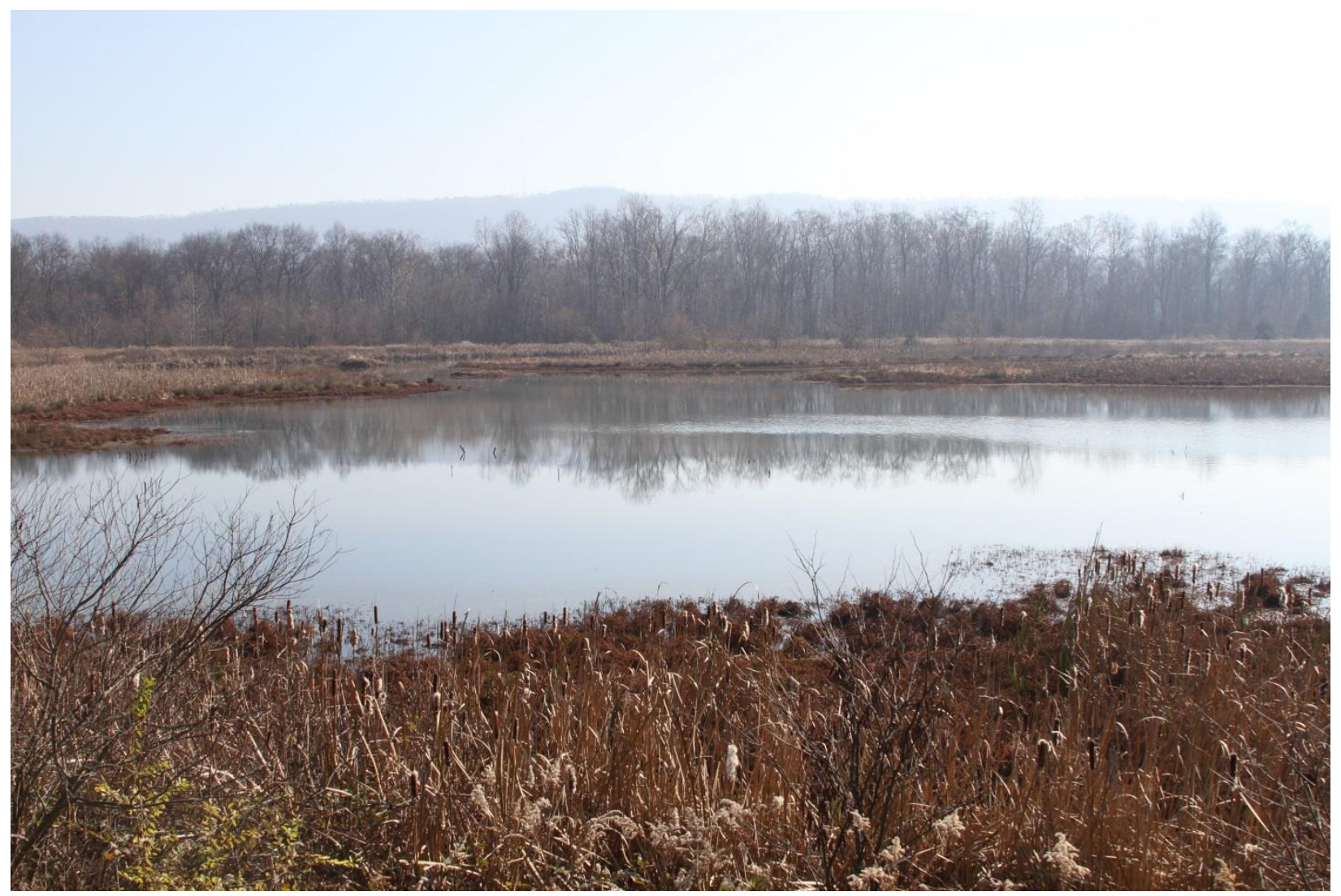

Figure 9. Photograph of Stauffer's Marsh, a created wetland in Berkeley County, West Virginia, 2010. 


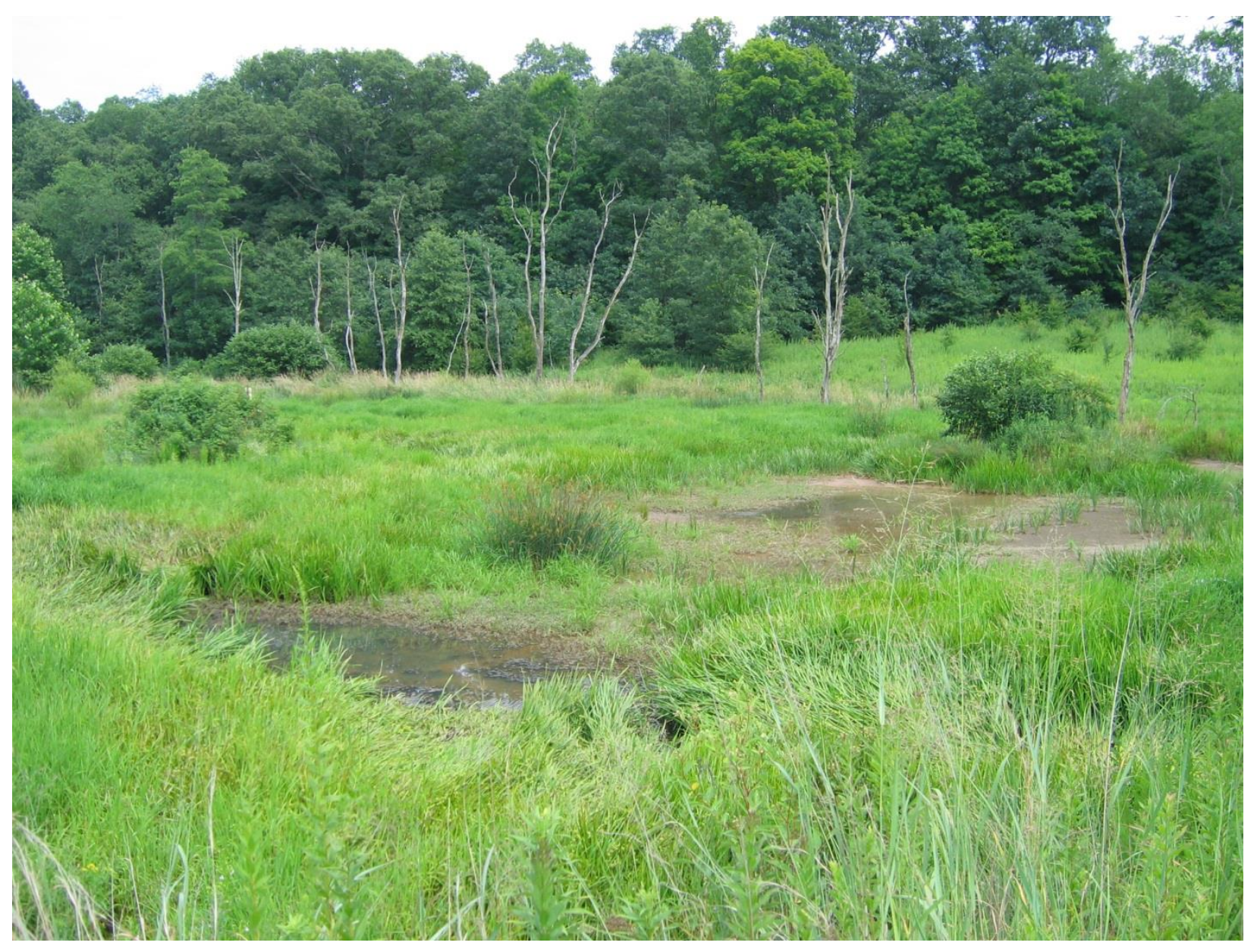

Figure 10. Photograph of Sugar Creek, a created wetland in Barbour County, West Virginia, 2010. 


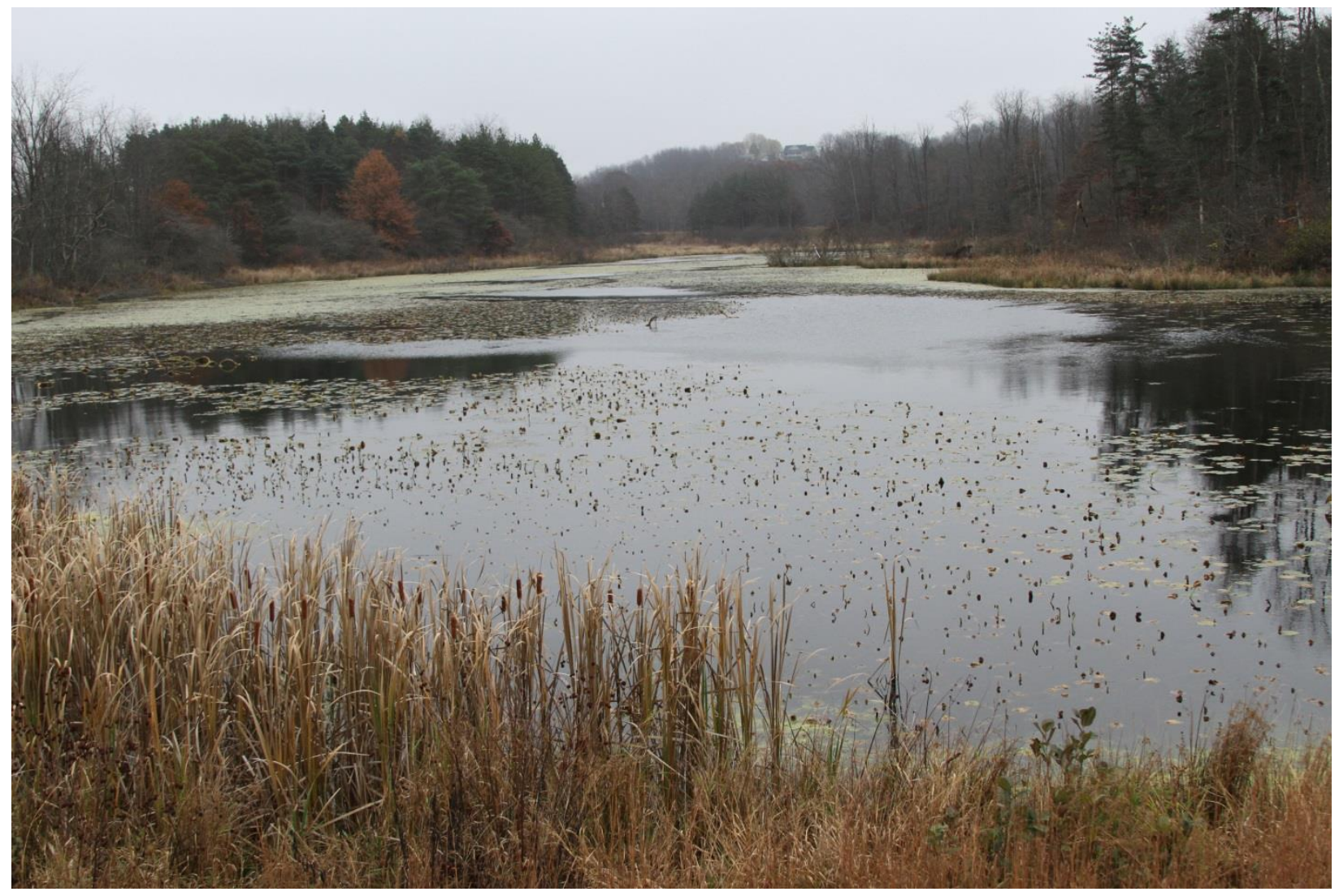

Figure 11. Photograph of Upper Deckers Creek WMA, a created wetland in Preston County,

West Virginia, 2010. 


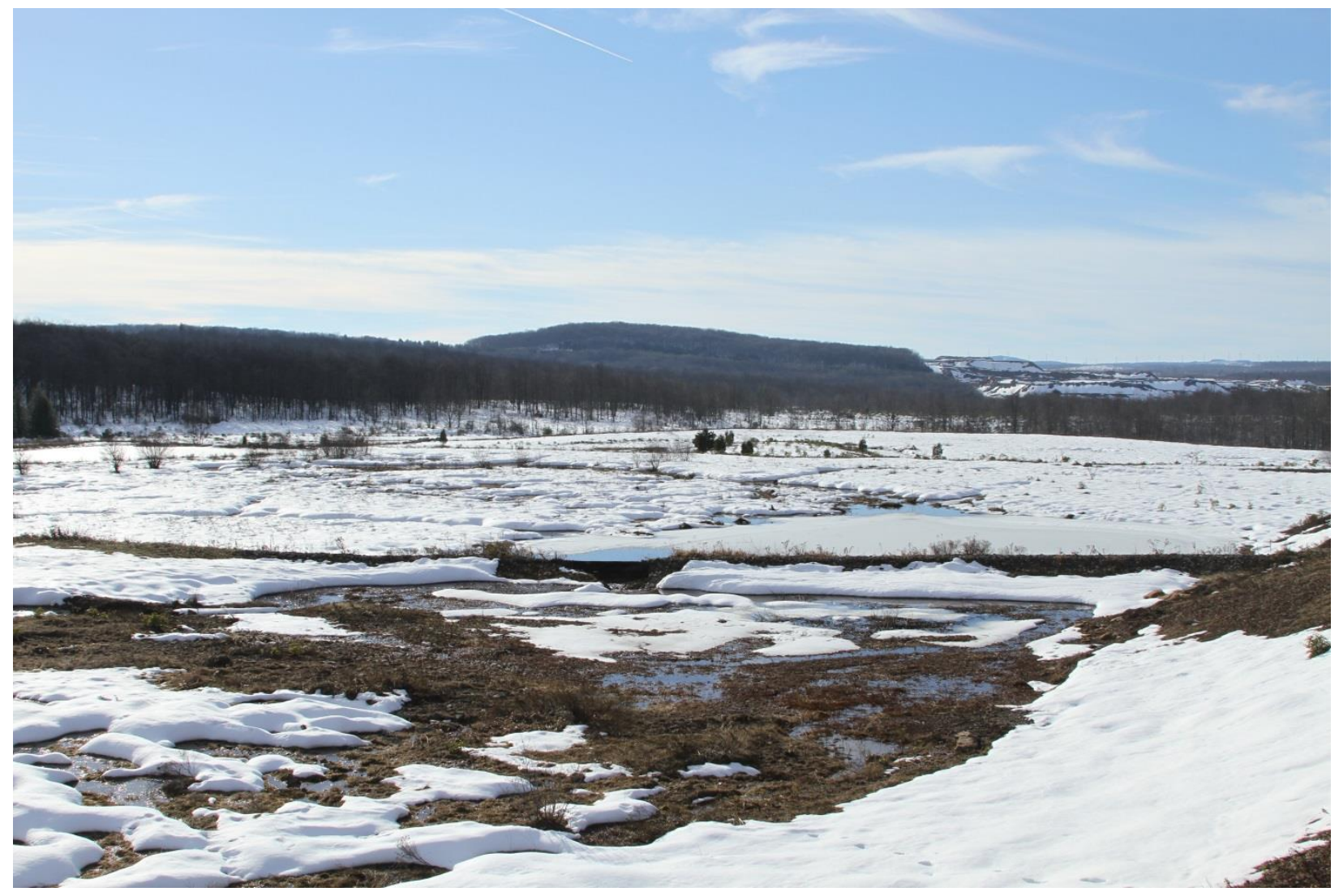

Figure 12. Photograph of VEPCO, a created wetland in Tucker County, West Virginia, 2010. 


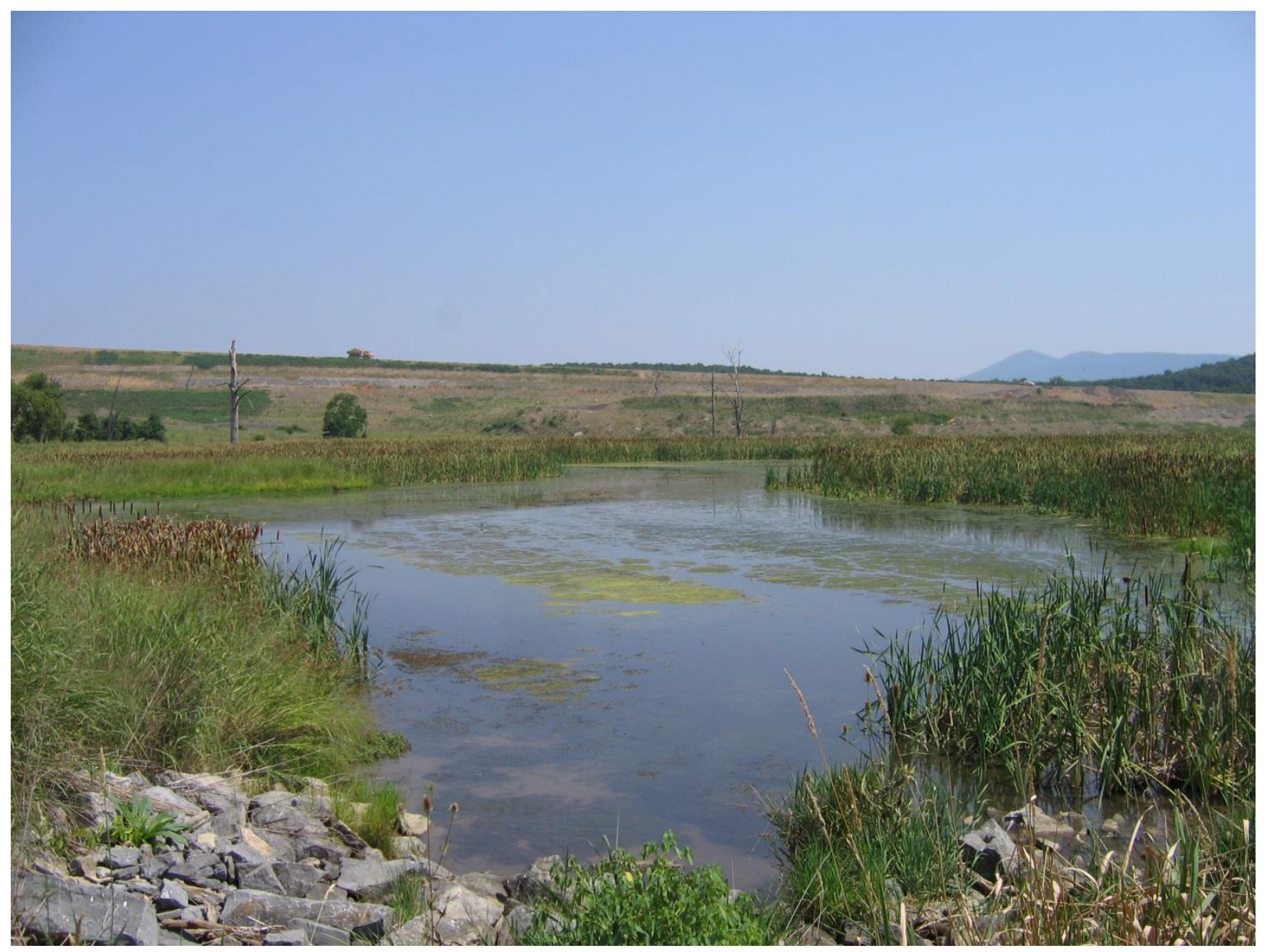

Figure 13. Photograph of Walnut Bottom, a created wetland in Hardy County, West Virginia, 2010 . 


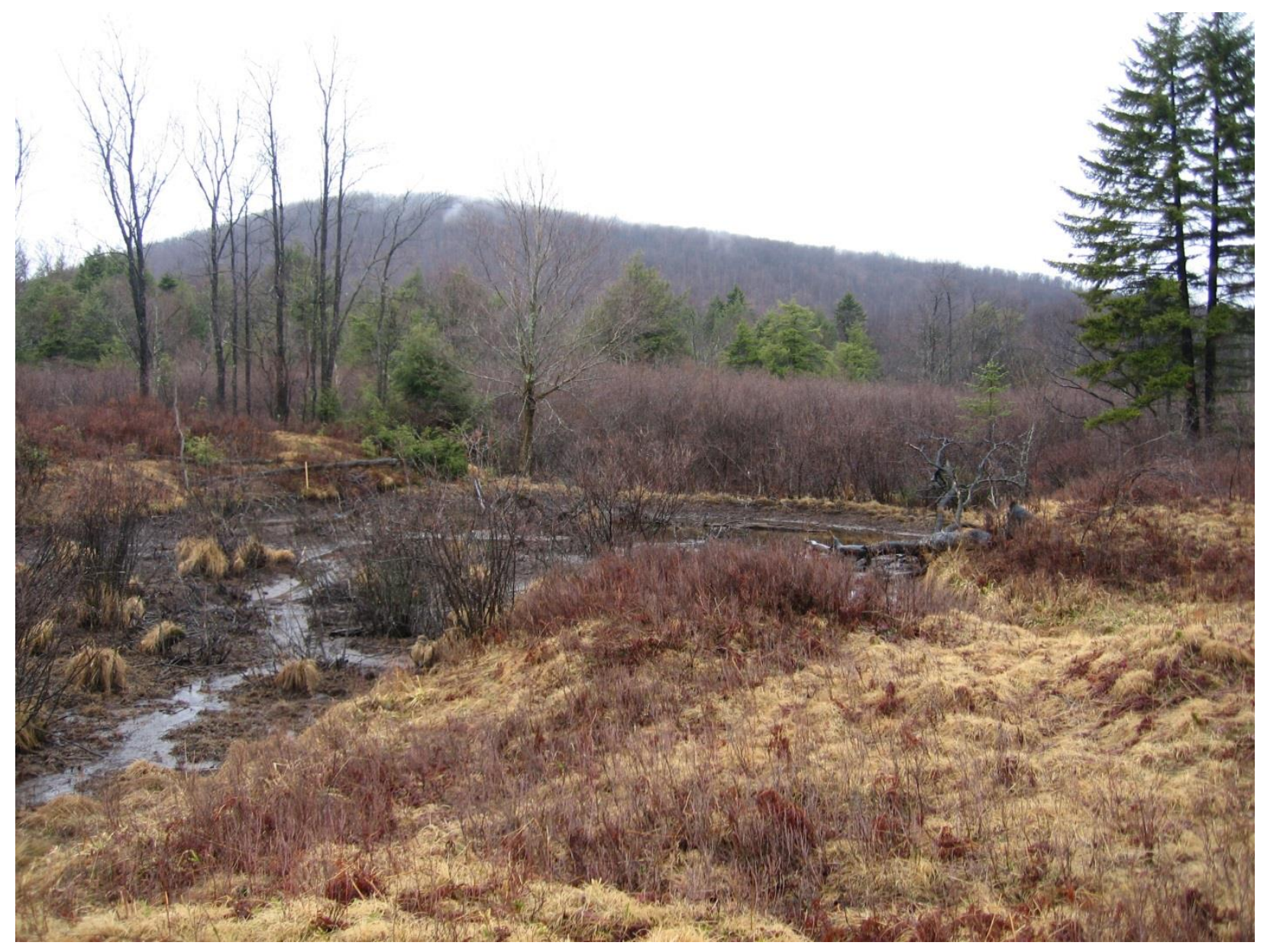

Figure 14. Photograph of Camp 70, a natural wetland in Tucker County, West Virginia, 2010. 


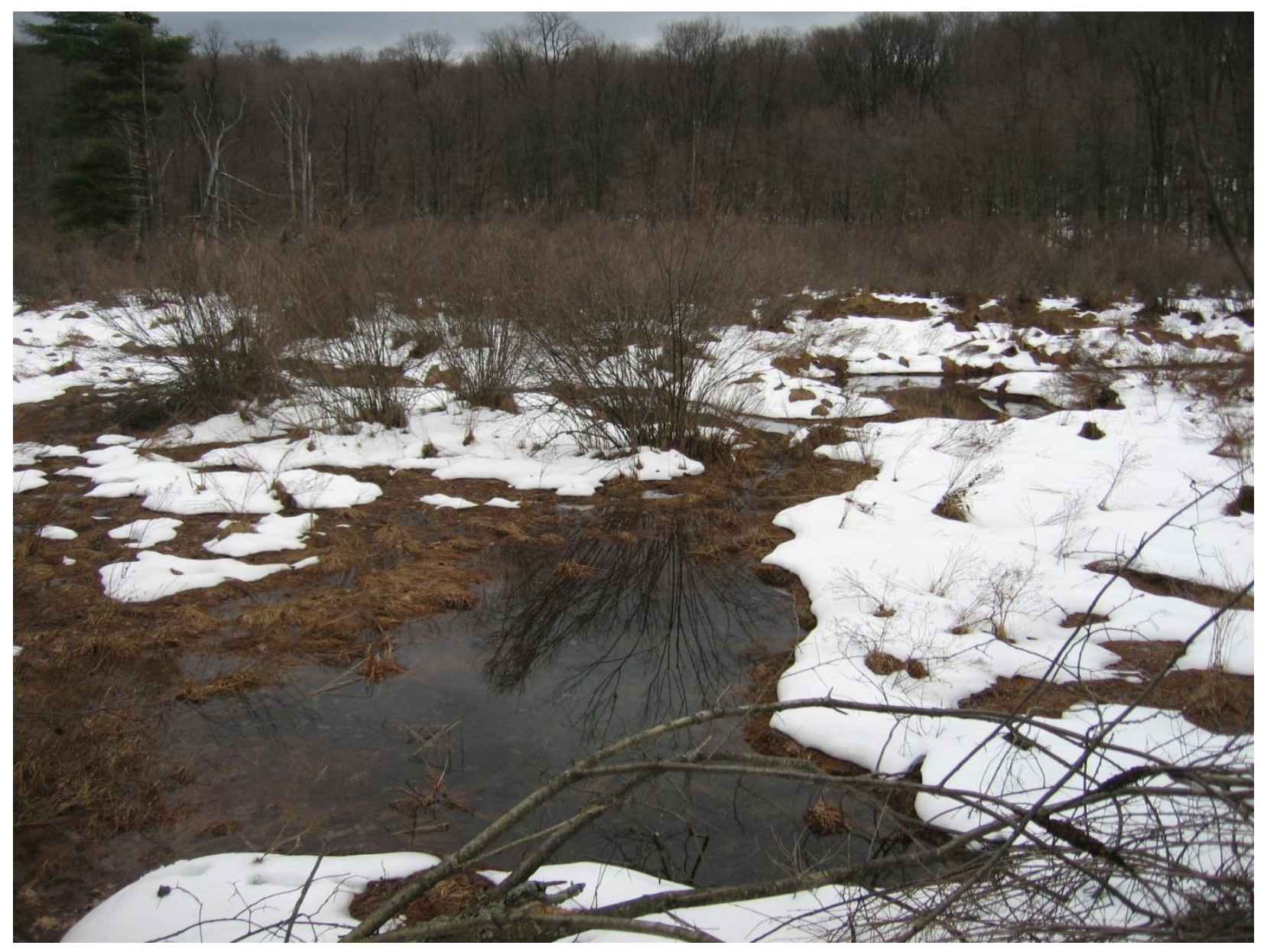

Figure 15. Photograph of Garrett State Forest North, a natural wetland in Garrett County, Maryland, 2010. 


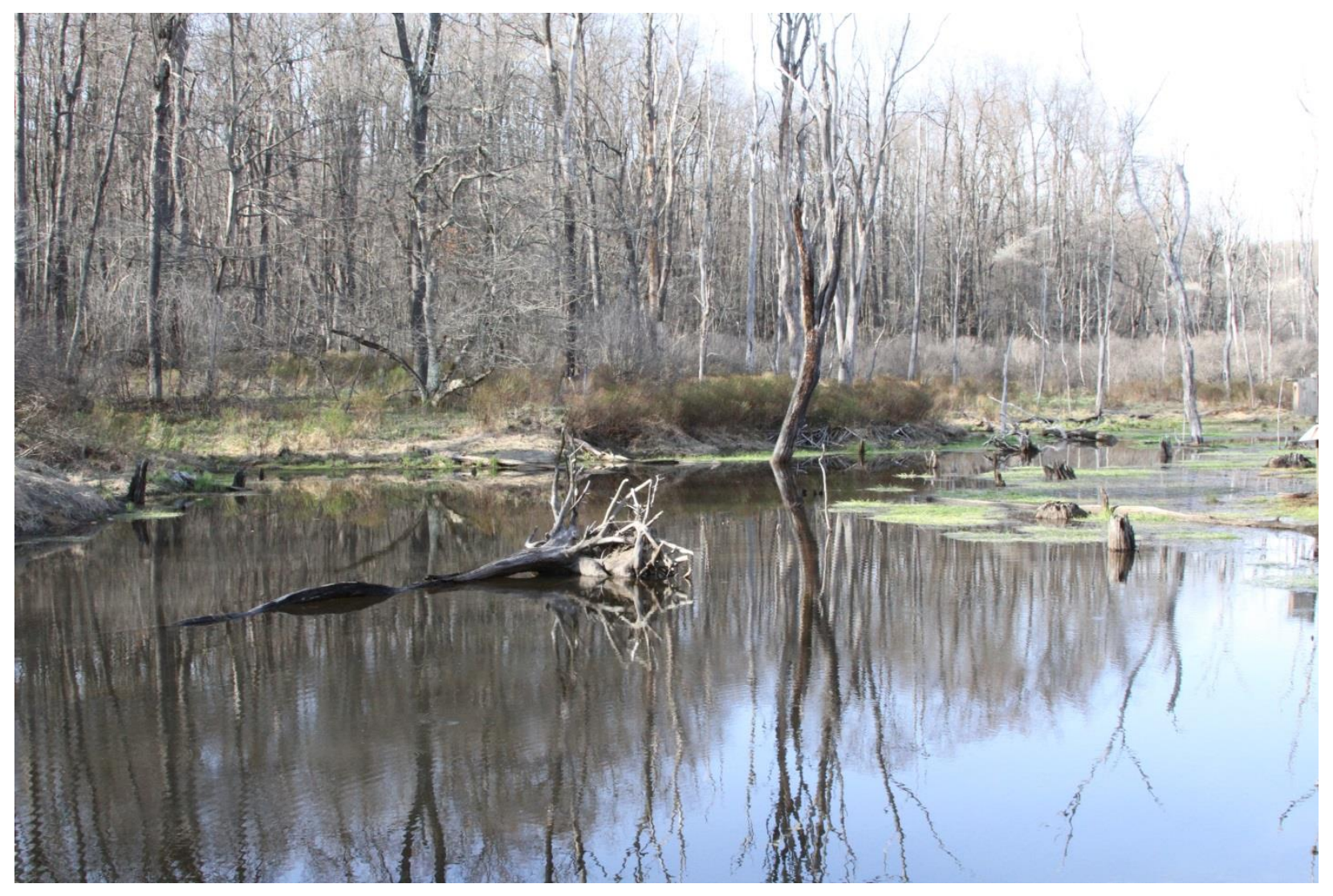

Figure 16. Photograph of Garrett State Forest South, a natural wetland in Garrett County,

Maryland, 2010. 


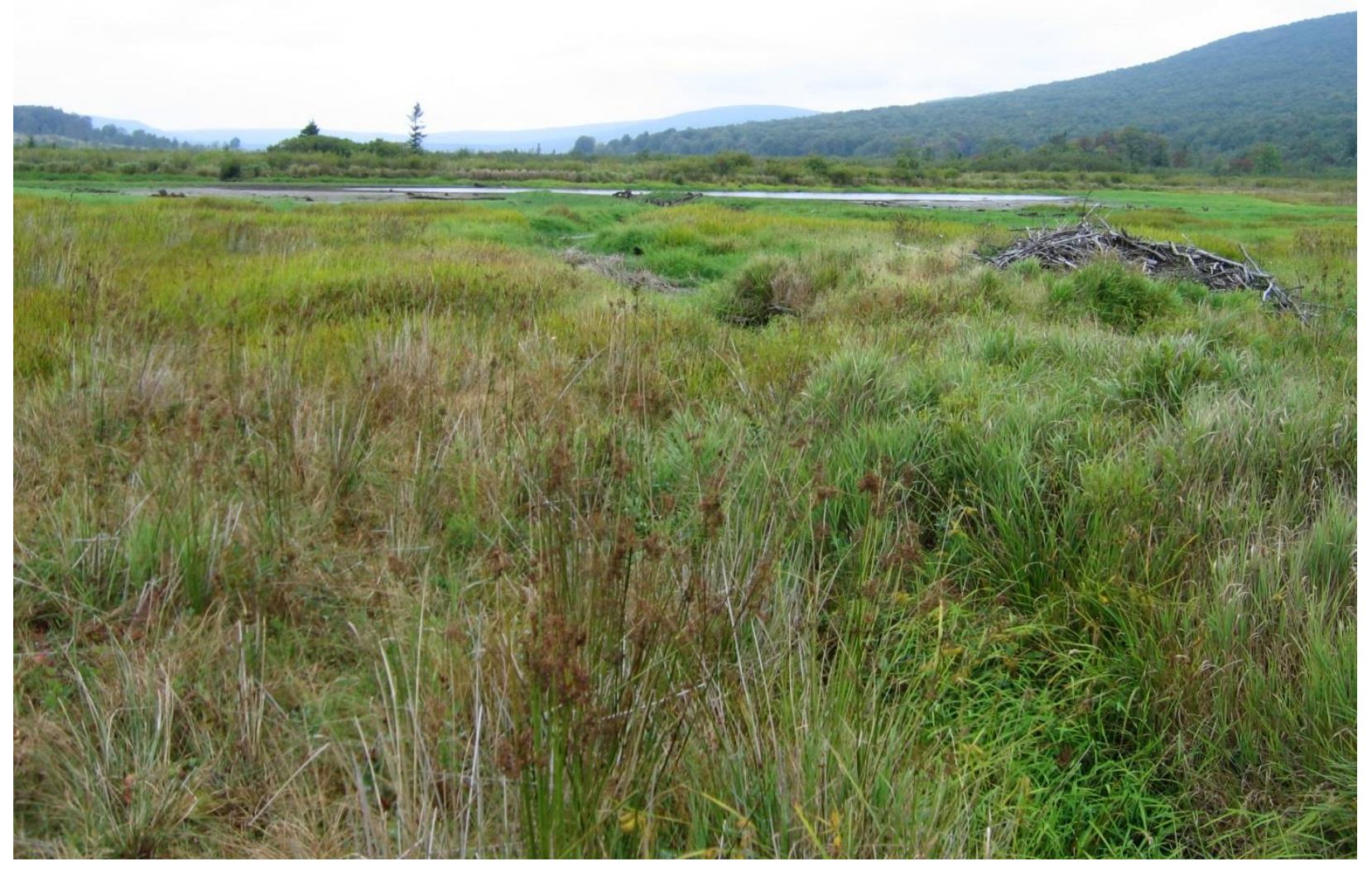

Figure 17. Photograph of Glade Run Beaver Pond, a natural wetland in Tucker County, West Virginia, 2010. 


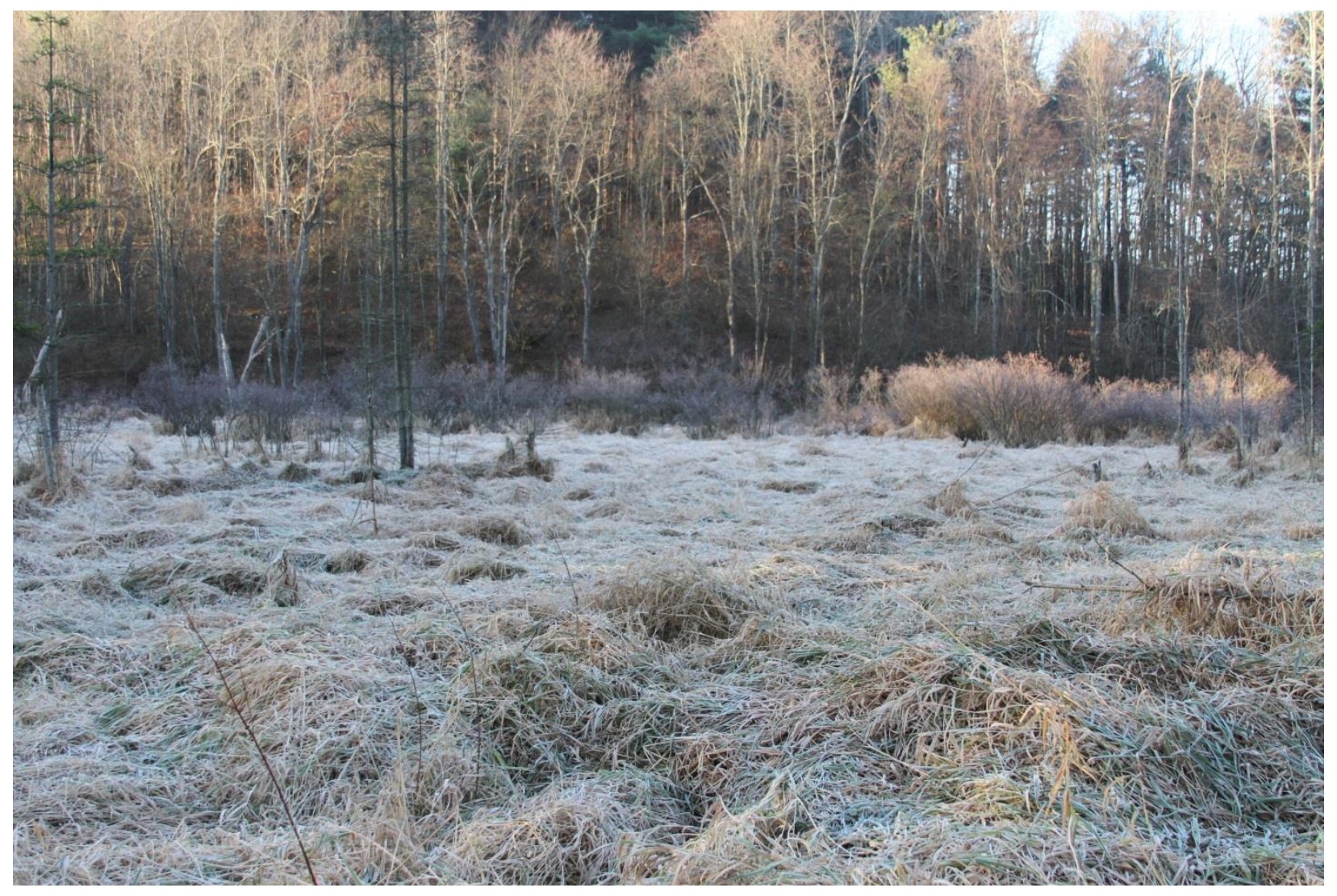

Figure 18. Photograph of Joe Mood, a natural wetland in Preston County, West Virginia, 2010. 


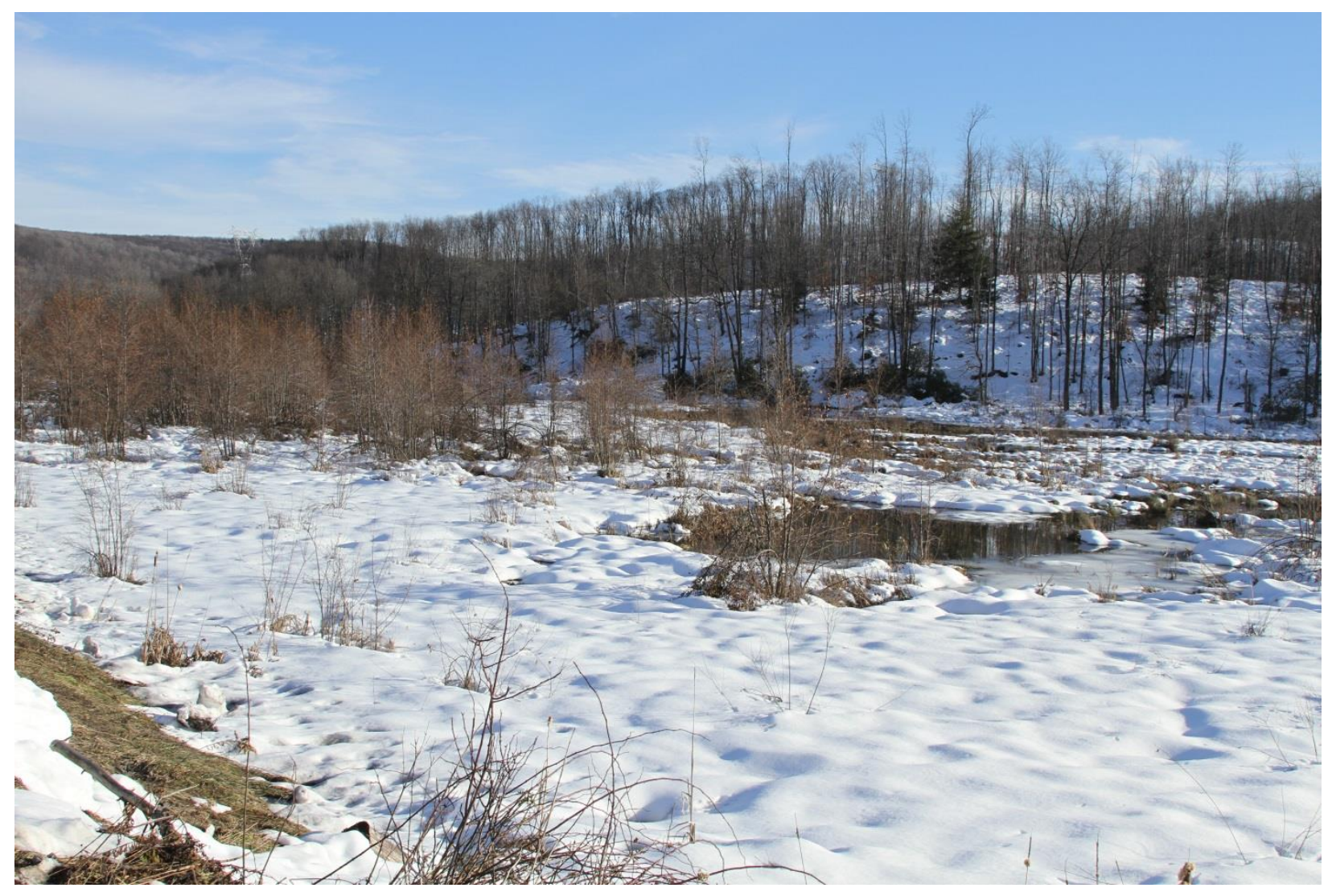

Figure 19. Photograph of Kempton Swamp, a natural wetland in Garrett County, Maryland, 2010. 


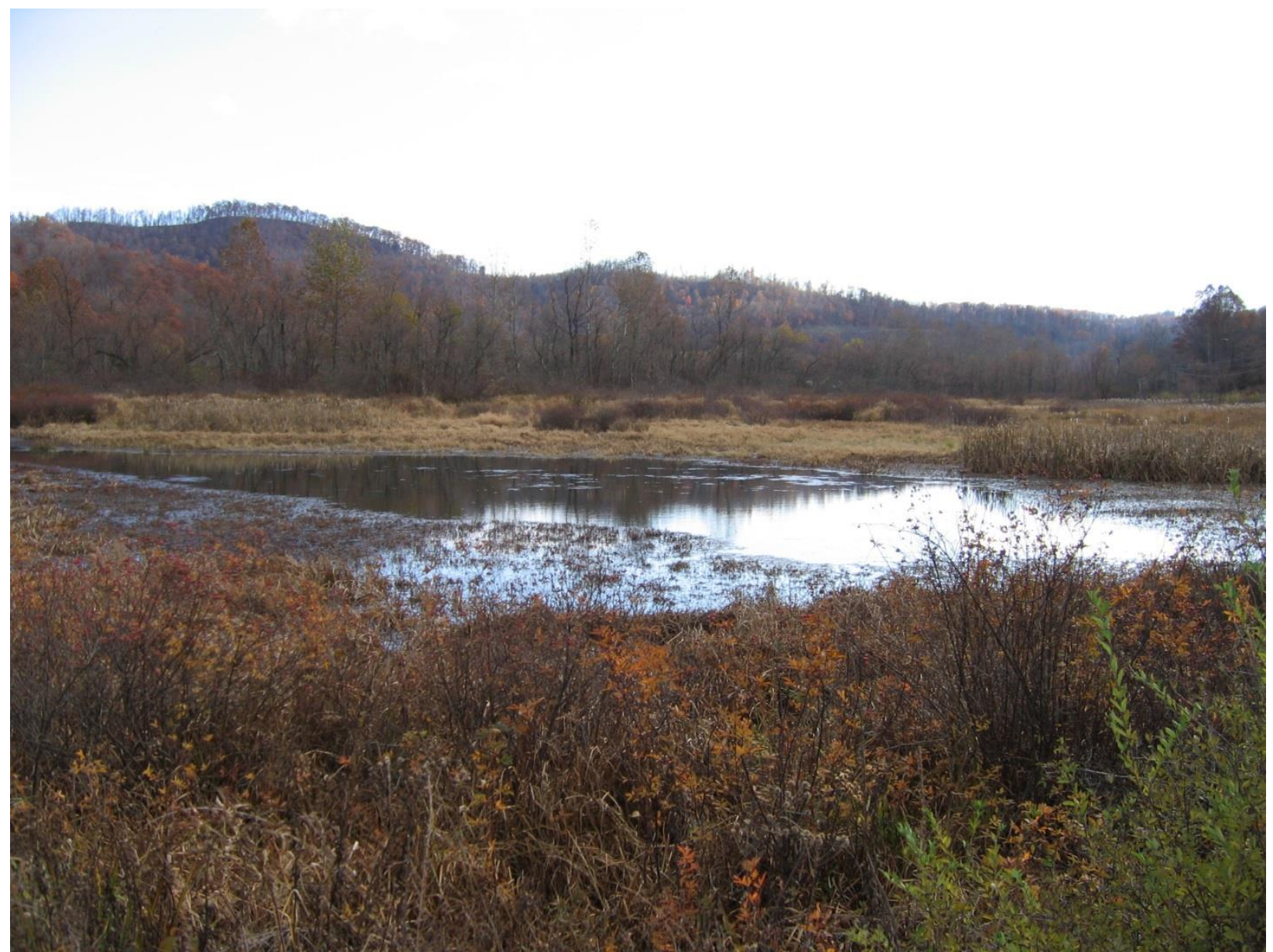

Figure 20. Photograph of Muddlety, a natural wetland in Nicholas County, West Virginia, 2010. 


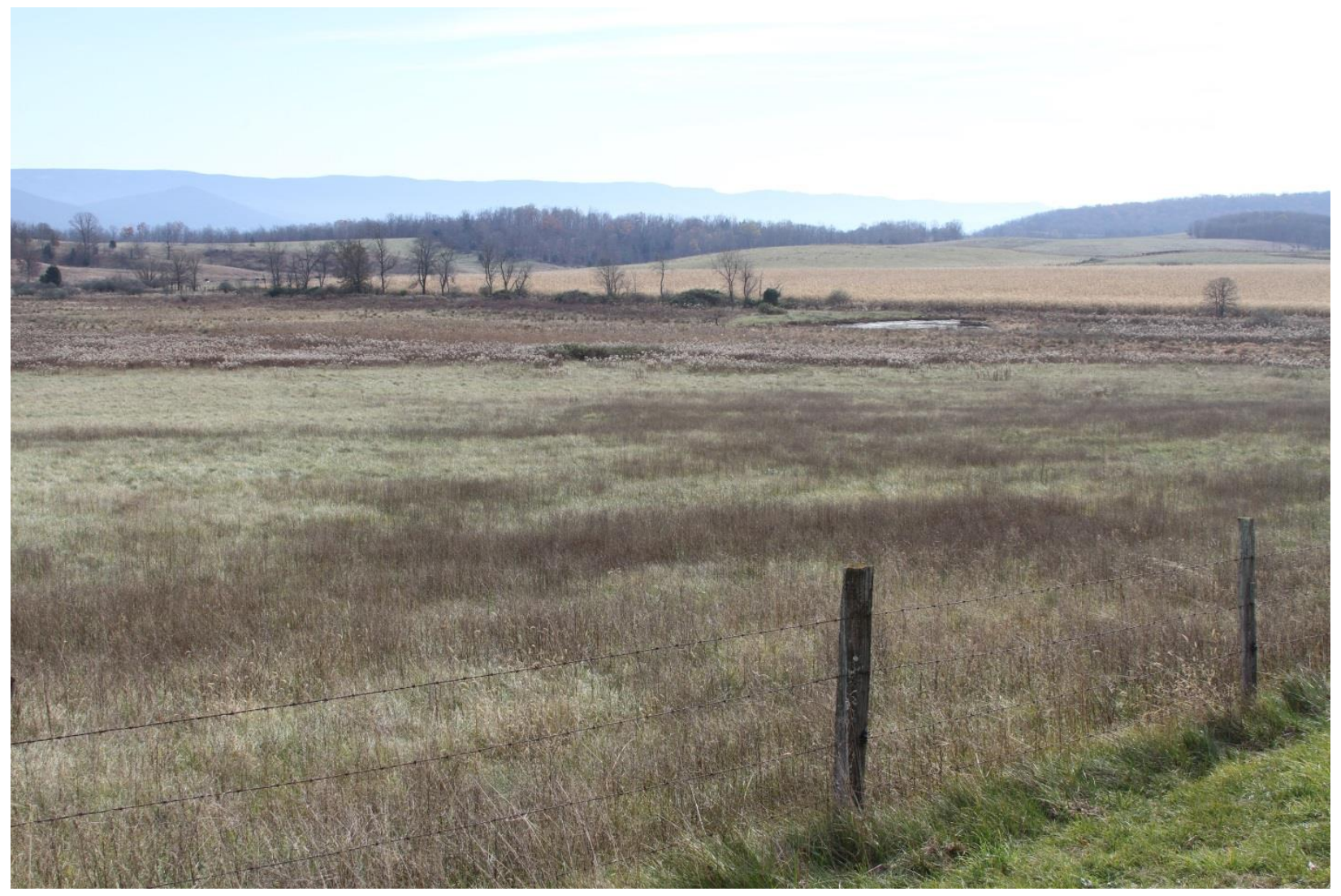

Figure 21. Photograph of Old Fields, a natural wetland in Hardy County, West Virginia, 2010. 


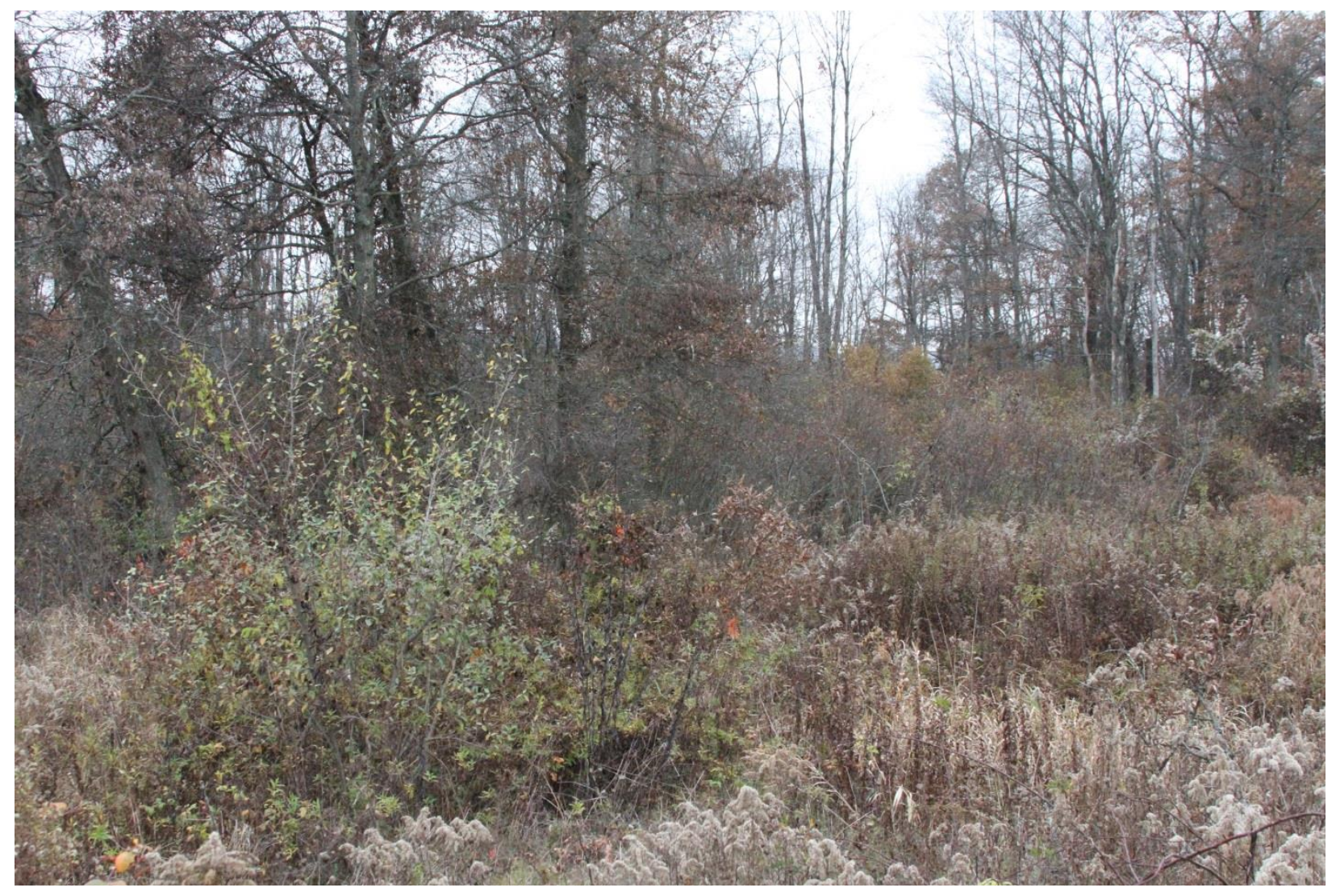

Figure 22. Photograph of Rail Trail North, a natural wetland in Preston County, West Virginia,

2010. 


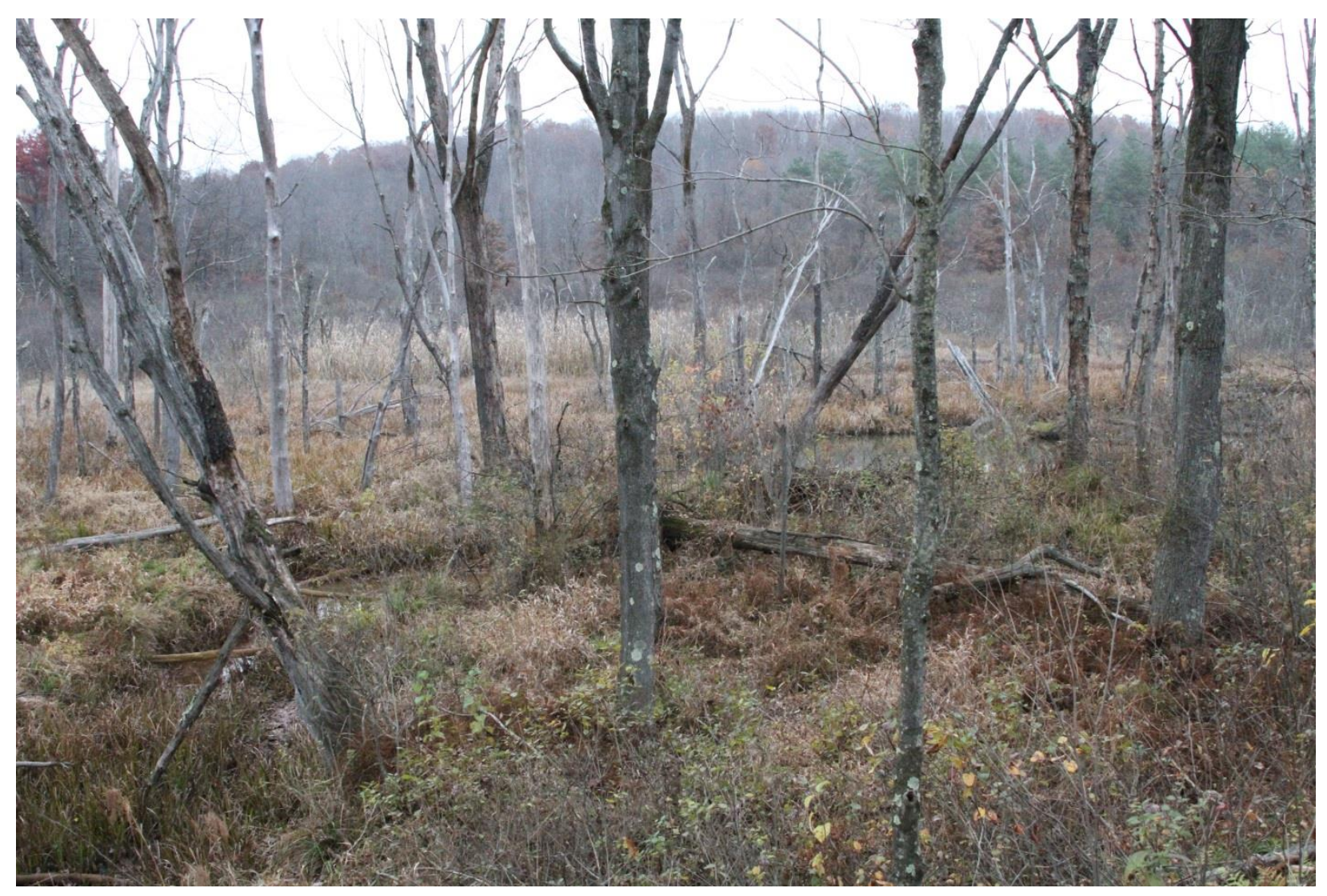

Figure 23. Photograph of Rail Trail South, a natural wetland in Preston County, West Virginia, 2010. 


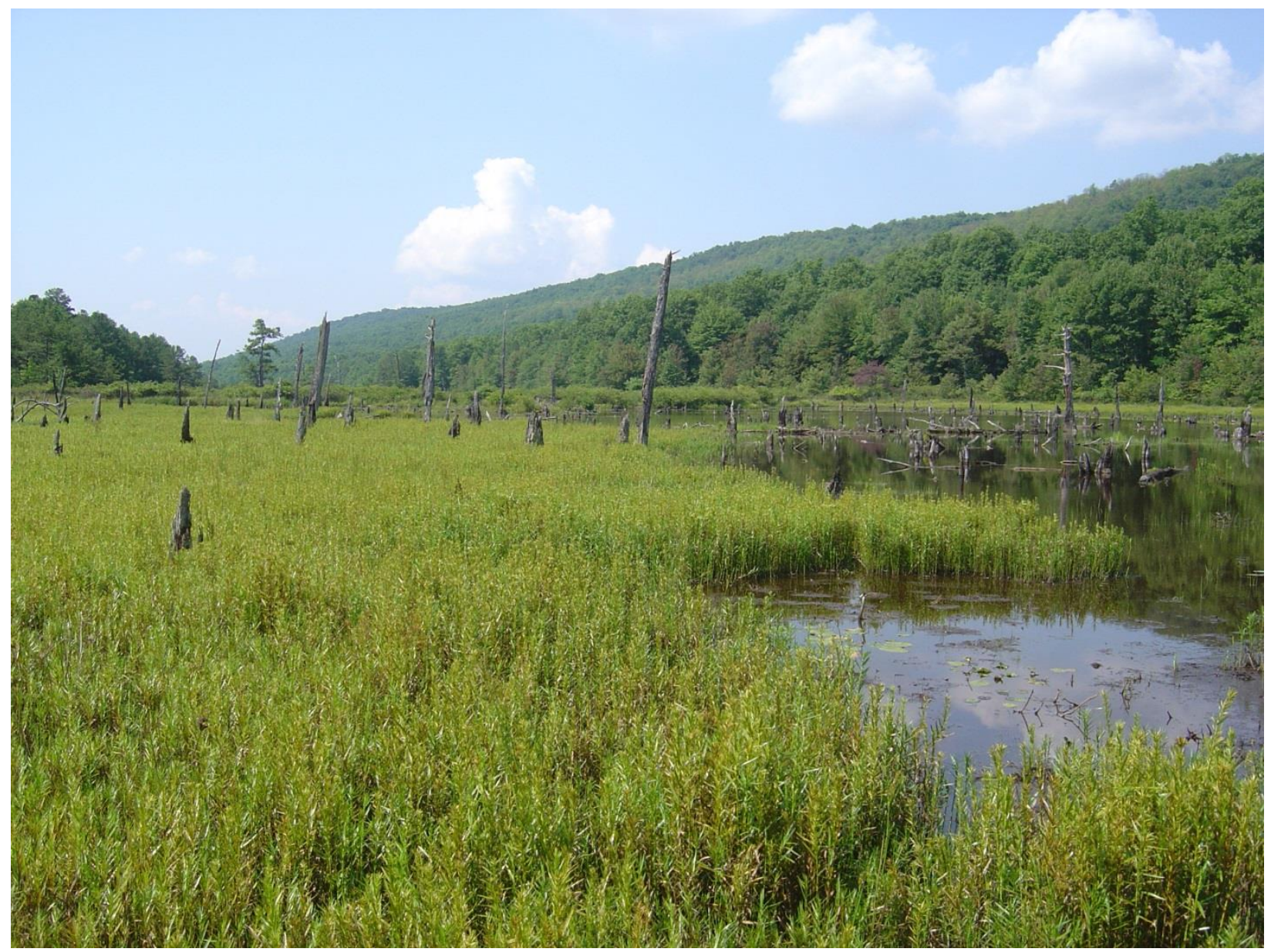

Figure 24. Photograph of Short Mountain, a natural wetland in Hampshire County, West Virginia, 2010. 


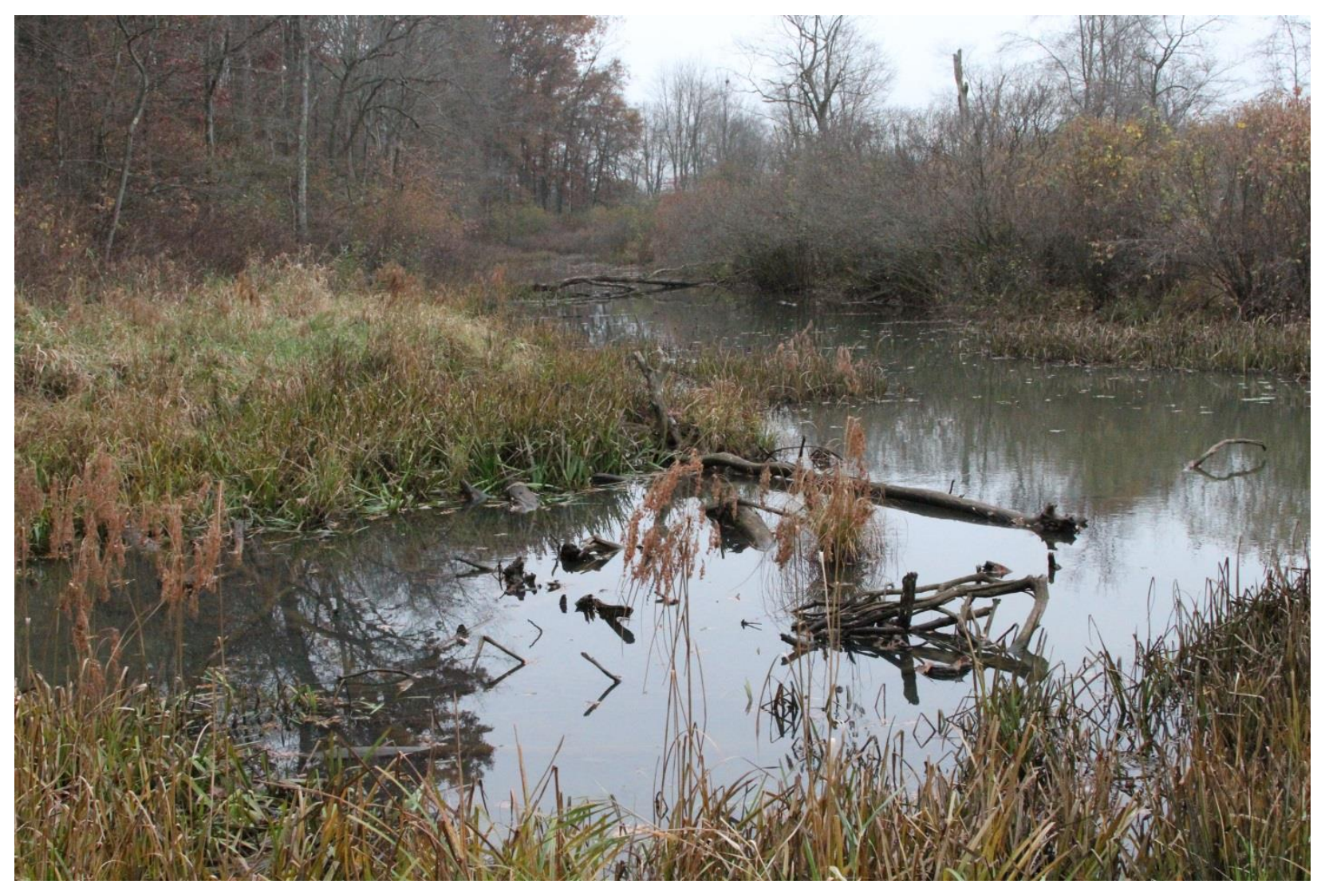

Figure 25. Photograph of Upper Deckers Creek, a natural wetland in Preston County, West

Virginia, 2010. 


\section{CHAPTER II}

AMPHIBIAN REPRODUCTIVE SUCCESS AS A GAUGE OF FUNCTIONAL EQUIVALENCY OF CREATED WETLANDS IN THE CENTRAL APPALACHIANS

Gabriel F. Strain ${ }^{1 *}$, Philip J. Turk ${ }^{2}$, Jordan Helmick ${ }^{2}$, and James T. Anderson ${ }^{1,3}$

${ }^{1}$ West Virginia University, Division of Forestry and Natural Resources, PO Box 6125, Morgantown, WV 26506-6125

*Corresponding Author e-mail: gstrain54@yahoo.com

${ }^{2}$ West Virginia University, Department of Statistics, PO Box 6330, Morgantown, WV 26506-6125

${ }^{3}$ West Virginia University, Environmental Research Center, Morgantown, USA

Written in the style of:

Journal of Fish and Wildlife Management 
September 13, 2013

Gabriel F. Strain

West Virginia University

322 Percival Hall, Morgantown, WV 26506

Phone 443/938-2169; Fax: 304/293-2441

Gstrain54@yahoo.com

RH: Strain et al. • Amphibian Reproduction in Created Wetlands

Amphibian Reproductive Success as a Gauge of Functional Equivalency of Created

Wetlands in the Central Appalachians

GABRIEL F. STRAIN, ${ }^{1}$ Division of Forestry and Natural Resources, West Virginia University, P.O. Box 6125, Morgantown, WV, 26506, USA

PHILIP J. TURK, Department of Statistics, West Virginia University, P.O. Box 6330,

Morgantown, WV, 26506, USA

JORDAN HELMICK, Department of Statistics, West Virginia University, P.O. Box 6330, Morgantown, WV, 26506, USA

JAMES T. ANDERSON, Environmental Research Center and Division of Forestry and Natural Resources, West Virginia University, P.O. Box 6125, Morgantown, WV, 26506, USA

${ }^{1}$ Corresponding author: gstrain54@yahoo.com

\begin{abstract}
Evaluating the adequacy of created wetlands to replace the functions of lost natural wetlands is important because wetland mitigation is a major tool used to offset wetland losses. However, measurements such as vegetative cover and presence of wildlife may not provide sufficient evidence that created wetlands are functioning properly and thus examining the ecology of wetland biota such as that of amphibians may be a more useful surrogate for function. The objectives of this study were to compare the abundance of amphibian metamorphs and
\end{abstract}


survival and growth of larval amphibians in created wetlands relative to natural wetlands. Amphibian metamorphs were trapped in created and natural wetlands during the spring and summer of 2009 and 2010, and 165 green frog (Lithobates clamitans) larvae were raised during the spring of 2010 in laboratory aquaria containing water from created or natural wetlands. Abundance of spring peeper (Pseudacris crucifer) metamorphs decreased significantly from 2009 to 2010 and abundance of green frog metamorphs increased with habitat complexity, but both were unaffected by wetland type. Detection probability of metamorphs of both species was very low, increased with water temperature, and declined with month of observation. Survival, growth curves, and mass were similar between green frog larvae raised in created and natural wetland aquaria. Our results suggest that the function of providing adequate breeding habitat for generalist amphibians such as green frogs and spring peepers is being fulfilled by the created wetlands that we examined.

KEY WORDS Anurans, Central Appalachians, Created Wetlands, Functional Equivalency, Green Frog, Lithobates clamitans, Mitigation, Pseudacris crucifer, Reproduction, Spring Peeper.

As an intermediate between fully aquatic and fully terrestrial systems (Dahl 2006), wetlands provide important ecosystem services (Mitsch and Gosselink 2007), including the provision of vital habitat to both wildlife and plants (Dahl and Johnson 1991, Balcombe et al. 2005a). Over one third of federally endangered or threatened plants and animals rely on wetlands (Dahl and Johnson 1991, EPA 2012), including amphibians. In West Virginia, 22 species of amphibians are considered wetland obligates (Pauley 2000). Many amphibian species depend on wetlands and spend all or part of their life cycle in them because wetlands are excellent sources of food, 
protection, and breeding opportunities (Gibbons 2003). In turn, amphibians provide an abundant and high energy food source for larger predators such as birds and mammals (Davic and Welsh 2004).

Wetlands have been viewed as an impediment to progress throughout most of United States history (Dahl 1990, Tiner 2002), and many wetlands have been destroyed as a result (Whigham 1999, Brinson and Malvarez 2002). Of the original 89.5 million ha of wetlands in the conterminous United States (circa 1780), approximately 47.3 million ha (53\%) have been lost (Dahl 1990); the United States continued to lose 116,000 ha per year through 2004 (Dahl 2006), but overall wetland losses have decreased substantially in recent years (Dahl 2011). Wetland losses occurred for a variety of reasons, such as hydrologic alterations (Mitsch and Gosselink 2007), but the destruction or alteration of wetland habitats, including the surrounding terrestrial landscape (Pope et al. 2000, Marsh and Trenham 2001), may be an important factor contributing to the current global decline of amphibian populations (Phillips 1990, Alford and Richards 1999). Wetland loss threatens amphibian populations because of habitat destruction and loss of wetland connectivity (Semlitsch and Bodie 1998, Gallant et al. 2007).

To combat this problem, the United States established a policy of "no net loss" of wetlands (Turner et al. 2001). Although avoidance of wetland impacts is preferred, when permitted damage to natural wetlands is unavoidable, the primary tool used to accomplish the no net loss goal is compensatory mitigation, which is the replacement or compensation of wetland area and function (Zedler 1996, Cole and Shafer 2002). The success of wetland mitigation is unclear because losses continue to outweigh gains in overall wetland area (Dahl 2011). In most cases, the success of created wetlands is judged by examining parameters such as hydrology, vegetative cover, soil, or the presence of wildlife; however, similar structure or species lists of a 
created wetland to a lost wetland does not necessarily mean that the created wetland functions in the same way (Campbell et al. 2002, Jelinski et al. 2011). For example, studies have found that functions such as nutrient cycling are not being adequately mitigated (Hossler et al. 2011). Therefore, assessment of the functions that created wetlands provide, such as provision of habitat for amphibians, may be a more suitable approach.

Balcombe et al. (2005a) found that created wetlands in West Virginia supported 7 species of amphibians, the same species found in reference sites. They also found that Wisconsin call index values and relative abundance of calling anurans were higher in mitigated wetlands compared to reference sites for 3 species, and similar for the remaining species. However, proclaiming success of created wetlands based solely on call index values and adult abundance may be misleading if adults call, but mortality of larvae results in reproductive failure (Petranka et al. 2003). If amphibians are attracted to created wetlands to breed but experience lowered reproductive success, then created wetlands may represent ecological traps (Schlaepfer et al. 2002). If so, created wetlands could negatively affect local amphibian populations by attracting adults away from higher quality habitat to breed in lower quality habitat, resulting in population decline. Reduced water quality in created wetlands may reduce reproductive success via a reduction in survival and growth of larval amphibians. An assessment of reproductive success of amphibians (i.e., abundance of metamorphs and larval survival and growth) is therefore needed to determine if created wetlands are adequate replacements for lost natural wetlands.

Evaluating the abundance of metamorphs in wetlands is not straightforward because amphibians are likely detected imperfectly (Schmidt 2003). Imperfect detection can severely bias estimates of abundance, trends, or comparisons between experimental or observational 
treatments, because failure to detect species that are present results in false absences (Yoccoz et al. 2001, MacKenzie et al. 2002). This problem can be demonstrated with the formula

$$
E(C)=N p,
$$

where $E(C)$ is the expected value of a count of individuals, $N$ is the true number of individuals, and $p$ is the detection probability (Nichols 1992). The estimate of $N$ is a function of both the count $C$ and the detection probability $p$. Comparisons between counts taken at multiple times or sites $\left(C_{1} / C_{2}\right)$ are only reliable if $p$ is constant between sampling times or sites (Yoccoz et al. 2001). Researchers have often either ignored or attempted to minimize variation in detection probability by using standardized methods, but in reality the assumption of constant detection probabilities is rarely if ever met (Yoccoz et al. 2001, MacKenzie and Kendall 2002). Detection probability may be affected by multiple factors such as weather conditions, habitat variability, sampling techniques, and observer experience. To make reliable inferences, it is important to partition variation in detection from variation in the variable of interest, such as abundance. Over the past decade, numerous methods have been developed that deal with imperfect detection, such as binomial mixture models which estimate abundance while simultaneously incorporating estimates of detection (Royle 2004a). Thus, the specific objectives of this study were to account for variable detection in the comparison of the abundance of amphibian metamorphs and evaluate the survival and growth rate of larval amphibians in created wetlands relative to natural wetlands.

\section{STUDY AREA}

We selected 6 created $(\overline{\mathrm{x}}=6.1$ ha, $\mathrm{SE}=1.4)$ and 6 reference $(\overline{\mathrm{x}}=2.5 \mathrm{ha}, \mathrm{SE}=0.6)$ wetlands for study (Fig. 1, Table 1). The West Virginia Division of Highways constructed the majority of 
created wetlands used in this study to offset losses to natural wetlands during the construction of 2 major highways (Gingerich and Anderson 2011). In the construction of these created wetlands, excavated wetland basins were lined with clay and topsoil, and seeded and planted with herbaceous and woody plant species, respectively. We paired each created wetland with a natural wetland similar in elevation (created $\overline{\mathrm{x}}=683.5 \mathrm{~m}, \mathrm{SE}=105.8 ;$ natural $\overline{\mathrm{x}}=667.2 \mathrm{~m}, \mathrm{SE}=109.8$ ) and underlying geology, factors that are thought to affect wetland habitat (Diehl and Behling 1982, Weakley and Schafale 1994, Halsey 1997, Bledsoe and Shear 2000, Francl et al. 2004). This focus on controlling elevation and geology resulted in some pairs that contained wetlands of disparate sizes. The majority of created wetlands in West Virginia and other states tend to be dominated by open water compared to natural wetlands (Cole and Brooks 2000, Balcombe et al. 2005b). Historic beaver (Castor canadensis)-created wetlands also tend to be dominated by open water (Naiman et al. 1988) and thus may approximate the conditions of created wetlands as amphibian habitat more so than other wetland types in the state. We thus selected beaver ponds for our reference wetlands. We determined the approximate size (ha) and perimeter (m) of each wetland basin (wetted margin) from aerial photographs using ArcMap 10.0 (ESRI, Redlands, CA). We calculated a measure of the habitat complexity (the sinuosity of the wetland basin; wetlands with more curvature resulting in shallows and backwater areas receive a higher score) of each wetland as the perimeter divided by the square root of the area $\left(\mathrm{m} / \mathrm{Jm}^{2}\right)($ Cunningham et al. 2007). 


\section{METHODS}

\section{Metamorph Sampling}

Because most of the wetlands in our study were large and heterogeneous with no well-defined "edge," the common practice of surrounding wetlands with drift fences to capture amphibians was not logistically feasible. Therefore, we conducted amphibian sampling via funnel traps and dipnet sweeps. We constructed funnel traps with fiberglass window screening following Micacchion (2002). After determining the approximate perimeter of each wetland, we randomly chose 15 positions along the perimeter, and placed 1 trap at each of these 15 positions.

Traps were positioned so that a portion of the trap was not submerged, allowing captured adult amphibians to breathe. We tethered each trap to a wooden stake with fishing line to prevent them from washing away during high water events. Funnel traps were opened once every month, and they remained open for 24 hours to maximize captures and to minimize mortality (Micacchion 2002). We visited paired sites as closely in time as possible to open the traps, and then returned the following day at approximately the same time to check and close the traps. We took the dipnet sample concurrently with trap checking. At each trap, we took a standardized dipnet sweep of approximately $1 \mathrm{~m}^{2}$ at a randomly selected spot within a $5 \mathrm{~m}$ radius of the trap (Micacchion 2002). We sampled from morning to midday (approximately 0800 to 1300) starting in early April and ending in late August in 2009 and 2010, for a total of 10 sampling occasions. When not in use, traps were placed on top of their respective stakes. Water temperature $\left({ }^{\circ} \mathrm{C}\right)$ was recorded with a standard thermometer (to the nearest $0.5^{\circ} \mathrm{C}$ ) at each site upon arrival before the initiation of sampling.

Metamorphs encountered in each trap and dipnet sweep were identified to species, and Gosner (1960) stage, which assigns a number based on hind limb development and other 
ontogenetic changes, was recorded. We designated as metamorphs all individuals at stage 42 or beyond (eruption of forelimbs). We released tadpoles and metamorphs at their capture location, with the exception of individuals we could not identify in the field; these individuals were euthanized with MS-222 (tricaine methanosulfate) and returned to the laboratory for identification.

\section{Larval Growth Rate and Survival}

To compare survival and growth rate of amphibian larvae between created and natural wetlands, we collected a sample of larval green frogs (Lithobates clamitans) and raised half of them in laboratory aquaria containing water from created wetlands and half in aquaria containing water from natural wetlands. We collected 180 tadpoles in March 2010 from a created wetland in Grant County, West Virginia $\left(39^{\circ} 12^{\prime} 45^{\prime} \mathrm{N}, 7^{\circ} 25^{\prime} 25^{\prime} \mathrm{W}\right)$. All individuals had hatched the previous summer and overwintered in the wetland and were of similar Gosner (1960) stage (30-33). We transported tadpoles to the laboratory where they were housed in 36 aquaria $(\sim 3 \mathrm{~L}$ plastic containers), with 5 larvae per aquarium. Because there were 6 wetlands of each type used in this study and 3 aquaria per wetland, each treatment had 18 replicates. We maintained aquaria on a 14 hour light: 10 hour dark photoperiod at approximately $22^{\circ} \mathrm{C}$. We fed tadpoles a consistent amount of food (3:1 mixture of rabbit chow and flake fish food, Skelly 1994) once every other day. In an attempt to achieve a balance between disturbing tadpoles and maintaining conditions as natural as possible, we did not aerate aquaria and limited water changes to $1 / 3$ of the water volume once a week with water collected from respective wetlands. As water was siphoned during water changes, we vacuumed uneaten food, feces, and debris from the bottom of aquaria. We randomly assigned aquaria to spaces along a 9 m-long bench. We randomly allocated individual tadpoles to aquaria containing water from either created or natural wetlands; thus, 
tadpoles were experimental units. For 84 weeks, we counted the number still alive and measured the mass of tadpoles weekly during water changes by placing them on a digital scale in a tared dish containing water from their respective aquaria. However, because tadpoles could not be individually identified (Strain et al. 2013), the wet mass of all tadpoles in an aquarium was averaged and aquaria became the experimental units for tadpole growth rate. Metamorphs were euthanized in a 2\% solution of MS-222 and deposited in the West Virginia University Natural History Museum teaching collection. We received approval from the West Virginia University (WVU) Institutional Animal Care and Use Committee (\#08-1001) to handle tadpoles and a scientific collecting permit was obtained from the West Virginia Division of Natural Resources (\#2009.006) to collect amphibians.

\section{Statistical Analyses}

Binomial mixture models involve the joining of 2 generalized linear models; a sub-model that characterizes local abundance $(N)$, and a sub-model that characterizes detection probability $(p)$ (Kery et al. 2009). We fitted Royle's (2004a) model to the capture histories of spring peeper (Pseudacris crucifer) and green frog metamorphs from the 12 paired wetlands across 5 sampling occasions for each of 2 years. Sample sizes of other species captured were too low for analyses. No spring peeper metamorphs were encountered during the first 2 sampling occasions and were thus most likely not present and therefore unavailable for sampling; therefore, we removed the first 2 occasions prior to analysis. We omitted the first sampling occasion for green frog metamorphs for the same reason. We captured no spring peepers in either wetland of pair 2 for both years, resulting in a capture history of zeroes; we eliminated this pair from the analysis of spring peeper metamorphs to improve model fit (McCune and Grace 2002). We suspected that abundance of metamorphs would relate to the size of the open water portion of the wetland 
basin. Therefore, as an initial step, using the modeling strategy described below, we modeled counts of metamorphs as a function of the logarithm of size (ha); the estimated coefficient for size was close to 1 for spring peepers, revealing that abundance scales nearly 1:1 with the size of the wetland. We thus included the size (on the log scale) of each wetland as an offset term when modeling abundance of spring peepers by fixing the regression coefficient for size to 1 .

Abundance of green frogs did not scale similarly with size; therefore, size was included when modeling abundance of green frogs as a covariate (its regression coefficient was not fixed to 1). Habitat complexity, water temperature, and month (April to August) were standardized to a mean of zero and standard deviation of 1 . To model abundance, we used a log-linear model in which the $\log$ of expected $N$ varied as a function of wetland type (created or natural), wetland pair, year, and complexity. We used the logit link to model detection probability $p$ as a function of water temperature and month. We modeled all possible combinations of abundance terms, including a null model (containing only an intercept term), but both detection covariates (water temperature and month) were kept in all models. We used 3 distributions for $N$ (Poisson, zeroinflated Poisson, and negative binomial) for each model, for a total of 96 models. We estimated model parameters with maximum likelihood estimation using the "unmarked" package in the freely downloadable software package $\mathrm{R}$ (version 2.15.2). We selected the model that best fit the data via Akaike's Information Criterion (AIC). Models within 2 AIC units of the model with the smallest AIC were considered well-supported (Burnham and Anderson 2002), and we selected the most parsimonious model as our final model. To test each variable in the final model (at a significance value of 0.05 ), we used likelihood ratio tests (wetland pair) or Wald tests (year, complexity, month, and water temperature). 
During week 5 of the laboratory experiment, we experienced a large mortality event in which $27 \%$ of the tadpoles died. Because survivorship by wetland type may have differed before and after the die-off, we modeled the mortality event. To do so, we counted the number of larvae alive at the end of week 4 and the number of larvae that successfully transformed or survived until the termination of the experiment. Assuming a binomial distribution, we used a generalized linear mixed model with a logit link to model the number of tadpoles surviving as a function of 2 fixed factors (wetland type and mortality event) and 2 random factors (aquarium nested within wetland pair). The mortality event was considered a within-subjects factor to account for autocorrelation introduced by modeling each aquarium before and after the event. We also included the interaction between wetland type and mortality event. We performed a likelihood ratio test to assess aquarium-to-aquarium variation. A significance value of 0.05 was used in testing null hypotheses and we used PROC GLIMMIX in SAS version 9 for Unix (SAS Institute, Cary, North Carolina) to fit the model.

To compare the mass of laboratory tadpoles raised in created and natural wetlands, we fitted a weighted linear mixed model with random coefficients under REML. The model was weighted by the number of tadpoles (which gradually declined throughout the study) used to calculate the mean mass of tadpoles in each aquarium. The random coefficients model was used to account for the unequal mass profile lengths of aquaria (the profile of a particular aquarium ended when all tadpoles either transformed or died). All 15 tadpoles from the 3 tanks for 1 wetland (Everhart Seep) died within 24 hours of the study initiation (most likely caused by a low $\mathrm{pH}$ of approximately 3.0); this wetland was thus omitted from analysis. Tanks were nested within wetlands, both as random factors, and we included as fixed factors in the mixed model wetland type, week, and initially week $\times$ type, week $\times$ week, and week $\times$ week $\times$ type. We then performed 
a likelihood ratio test to examine variation between created and natural wetlands with respect to mass profile intercept, slope, and curvature. Because profiles were similar (see results), we pooled profiles from created and natural wetlands for further analysis. We simplified our model by omitting slope and curvature (see results) and performed a likelihood ratio test to examine variation in the intercept from aquaria-to-aquaria. We then fitted our model with an order 1 autoregressive (AR1) error covariance structure, and tested each main effect for significance. We used a significance value of 0.05 in testing null hypotheses and used SAS version 9 for Unix (SAS Institute, Cary, North Carolina) to perform the mass analyses. We performed residual diagnostics to check model assumptions for all analyses.

\section{RESULTS}

\section{Metamorph Abundance}

We encountered metamorphs of 7 amphibian species (spotted salamander, Ambystoma maculatum; Cope's gray treefrog/gray treefrog, Hyla chrysoscelis/versicolor; spring peeper; green frog; American bullfrog, Lithobates catesbeianus; pickerel frog, Lithobates palustris; and wood frog, Lithobates sylvaticus, Table 2). Eighty-six metamorphs of 6 species were encountered in created wetlands $(\overline{\mathrm{x}}=14.3$ metamorphs/wetland, $\mathrm{SE}=4.62$, range $=0-33)$. Sixty-one metamorphs of 4 species were encountered in natural wetlands $(\overline{\mathrm{x}}=10.2$ metamorphs/wetland, $\mathrm{SE}=4.35$, range $=0-28)$.

The best ranked model describing abundance of spring peeper metamorphs was fit using a zero-inflated Poisson distribution and contained 10 parameters including the excess zero parameter, wetland pair, and year, but did not include wetland type (Table 3). Mean abundance of metamorphs decreased by an estimated $86 \%(95 \%$ C.I. $=62 \%, 95 \%)$ from 2009 to 2010, but 
omission of wetland type in the final model suggested that abundance was similar between created and natural wetlands. Water temperature and month significantly affected detection of spring peepers, but in opposite directions: detection probability increased with water temperature and decreased over time (Table 3). In terms of odds ratios (derived by exponentiating the logit scale estimates), the odds of detecting spring peeper metamorphs was estimated to be 4.9 (95\% C.I. $=1.0,23.3)$ times greater with every standardized unit increase in water temperature. The odds of detecting metamorphs was estimated to be $0.9(95 \%$ C.I. $=0.7,1.0)$ times less for every standardized unit increase in month. Likelihood ratio tests confirmed the inclusion of wetland pair in the final model $\left(X^{2}=18.61\right.$, d.f. $\left.=4 P<0.001\right)$; wetland pairs were highly variable with respect to spring peeper metamorph abundance. We compared the best model against the null model with a likelihood ratio test to confirm the explanatory capability of the parameters contained in the model; wetland pair, year, water temperature, and month had significant explanatory capability $\left(X^{2}{ }_{7}=160.32, P<0.001\right)$. Using a logistic transformation in conjunction with the Delta Method, we calculated an estimate of the probability that a value is an excess zero as $0.32(95 \%$ confidence interval $=0.11,0.63)$, which provided evidence that our spring peeper dataset contained excess zeroes and affirmed the use of a zero-inflated Poisson distribution.

The best ranked model describing abundance of green frog metamorphs was fit assuming a Poisson distribution with 10 parameters, and contained wetland pair and habitat complexity, but not wetland type (Table 3). Abundance of green frog metamorphs increased with habitat complexity. Water temperature and month significantly affected detection of green frog metamorphs but, again, in opposite directions (Table 3). In terms of odds ratios, the odds of detecting green frog metamorphs was estimated to be $2.4(95 \%$ C.I. $=1.8,3.2)$ times greater with every standardized unit increase in temperature and $0.35(95 \%$ C.I. $=0.1,0.5)$ times less for 
every standardized unit increase in month. Likelihood ratio tests revealed that inclusion of wetland pair in the final model was warranted $\left(X^{2}{ }_{6}=70.58, P<0.001\right)$ and that the explanatory power of the parameters included in the final model was significantly better than an interceptonly model $\left(X^{2}{ }_{8}=83.05, P<0.001\right)$.

\section{Larval Growth Rate and Survival}

Survival of laboratory tadpoles was significantly affected by the mortality event $\left(F_{1,26}=61.09, P\right.$ $<0.001)$, but did not depend on wetland type $\left(F_{1,25}=0.01, P=0.94\right)$. Mean estimated probability of survival to metamorphosis was $0.46(\mathrm{SE}=0.07)$ before the mortality event; whereas, it decreased to $0.11(\mathrm{SE}=0.03)$ after the event. Tadpoles raised in water from created and natural wetlands had a $0.25(\mathrm{SE}=0.07)$ and $0.24(\mathrm{SE}=0.07)$ mean probability of survival, respectively. The interaction between wetland type and mortality event was nonsignificant $\left(F_{1,26}=2.21, P=\right.$ 0.15), which suggested that survival between tadpoles raised in water from created and natural wetlands was similar before and after the mortality event. No wetland pair-to-pair variation in survival was detected, but significant aquarium-to-aquarium variation was present $\left(X^{2}{ }_{1}=5.80, P\right.$ $=0.02)$.

Likelihood ratio tests revealed that tadpole mass profiles were similar between created and natural wetlands with respect to variation in intercept, slope, and curvature of profiles $\left(X^{2}{ }_{3}=\right.$ $1.21, P=0.75)$; thus, we pooled profiles across wetland types for further analysis. We eliminated slope and curvature to simplify our model in order to increase our power for tests of the fixed effects and because the intercept estimate (0.13) was orders of magnitude larger than the estimates for slope and curvature (both < 0.001). Variation in the intercept from aquarium-toaquarium was significant $\left(X^{2}{ }_{1}=333.45, P<0.0001\right)$. Inclusion of the AR1 error structure was 
justified $\left(X^{2}{ }_{1}=1556.05, P<0.0001\right)$; weeks were highly correlated (AR 1 correlation estimate $=$ $0.97, \mathrm{SE}=0.01)$. The linear $($ week $\times$ type $)$ and quadratic $($ week $\times$ week $\times$ type $)$ interactions were nonsignificant $(P=0.18$ and 0.94 , respectively), suggesting that growth rates of tadpoles did not depend on wetland type. Mean mass of tadpoles was $1.98 \mathrm{~g}(\mathrm{SE}=0.25)$ in created wetlands and $2.01 \mathrm{~g}(\mathrm{SE}=0.24)$ in natural wetlands; this difference was not statistically significant $\left(F_{1,9}=\right.$ $0.01, P=0.93)$. Mass of tadpoles changed over time $\left(F_{1,377}=128.42, P<0.001\right)$, and was not linear $\left(F_{1,273}=68.35, P<0.001\right)$; this non-linearity was caused by an abrupt drop in mass approximately during weeks $3-15$ followed by a gradual increase (Fig. 2).

\section{DISCUSSION}

\section{Metamorph Abundance}

The reproductive success of spring peepers and green frogs inhabiting the created wetlands in our study was similar to that of natural wetlands; variation in production of metamorphs was driven by other factors (i.e., habitat complexity and time). Although more long-term data would be required to determine population trajectories, our study demonstrates that over the 2 seasons of our study, created wetlands functioned similarly to natural wetlands with respect to amphibian metamorph production, which suggests that these created wetlands may provide comparable habitat to natural wetlands, thus ensuring successful reproduction by amphibians. Other studies have demonstrated that created wetlands function similarly to natural wetlands; for instance, successful reproduction was observed for 4 of 6 species in wetlands created to mitigate loss of natural wetlands in France (Lesbarreres et al. 2010). Western toads (Anaxyrus boreas) colonized and successfully bred in created wetlands in Oregon within several months of construction (Pearl and Bowerman 2006), as did wood frogs and spotted salamanders (Ambystoma maculatum) in 
North Carolina created wetlands (Petranka et al. 2003). Brand and Snodgrass (2009) highlighted the potential importance of created wetlands for amphibian breeding as reproductive success (measured by the presence of late-stage larvae) was observed in created wetlands, but not in natural wetlands. However, created wetlands may exhibit decreased or no production of metamorphs and therefore may act as ecological traps for at least some amphibian species (DiMauro and Hunter 2002). Although 12 amphibian species successfully reproduced in South Carolina created wetlands, Pechmann et al. (2001) asserted that the wetlands only "provided partial mitigation" because amphibian community structure differed in comparison to reference wetlands.

The decline of spring peeper metamorphs from 2009 to 2010 occurred in both created and natural wetlands. This decline was therefore not related to wetland creation but rather was most likely evidence of the high demographic variability that many amphibian populations exhibit (Trenham et al. 2003). Richter et al. (2003) found that the reproductive success of a dusky gopher frog (Lithobates sevosa) population varied considerably across 14 years. The authors found no relation between metamorph production and the number of adult females or the number of egg masses, which highlights the importance of assessing reproductive success to determine the adequacy of wetlands to support amphibians. Demographic variability may be influenced by weather or other factors with a lag of several years (Trenham et al. 2003); hence, monitoring wetlands for several years is ideal for accurately gauging functional equivalency (Pechmann et al. 2001). Although our study included only 2 years, close wetland-to-wetland proximity minimized regional weather variability; therefore, we believe that the similarity we found in reproductive success between wetland types is valid. This and most assessments would certainly benefit from the addition of more long-term data. 
Although numerous wetland habitat parameters exist, we only included a single factor (habitat complexity) to determine relations between reproductive success and wetland habitat. Our preliminary surveys of wetlands revealed large variation in the shape of created wetlands, ranging from roughly circular to very complex (i.e., several small interconnected pools or a sinuous shoreline containing one or more backwater shallow areas); natural wetlands exhibited similar variation. We a priori hypothesized that more complex wetlands would provide more ovipositing and refuge sites for amphibians and hence would exhibit increased reproductive success. Our results only partially support this, as abundance of metamorphs increased with habitat complexity for green frogs, but not spring peepers. In a Missouri study of amphibian assemblages, which included green frogs, metamorph production was overwhelmingly concentrated in experimental wetlands constructed with shallow slopes compared to those with steeper slopes (Shulse et al. 2012). We speculate that because shallow-water areas of wetlands experience increased growth of periphyton (an important food source for tadpoles) on the benthos and submergent and emergent vegetation (Robinson et al. 1997), these areas may provide increased resources for developing green frog larvae; hence, an increase in the number of individuals that survive to metamorphosis. If true, a lack of relation between habitat complexity and spring peeper metamorph production may be explained by spring peeper larvae's insensitivity to resource limitation (compared to green frogs, Skelly 1995). Other habitat variables are also known to influence amphibian reproductive success, including hydroperiod (DiMauro and Hunter 2002, Karraker and Gibbs 2009) and the presence of fish (Petranka et al. 2007, Shulse et al. 2012). The inclusion of more habitat variables may help elucidate what factors drive reproductive success in these wetlands. 
Wetland pair was included in top models describing metamorph production; clearly our wetland pairs were different from one another with respect to metamorph abundance. Although reasons for this difference were not of particular interest, it demonstrates the high variability that wetlands exhibit (Mitsch and Gosselink 2007). Unlike stream systems, which have a regional but predictable pattern of flora and fauna (Vannote et al. 1980), wetlands exhibit a wide range of variation in parameters including hydrology (Shaffer et al. 1999), vegetation (Byers et al. 2007), microbial activity (Groffman et al. 1996), and soil nutrients (Chambers and Pederson 2006). Many wetlands are unique due to this remarkable variation, and making generalizations about wetlands is thus difficult. In this study, we selected a wide range of study wetlands because our objective was to gauge created wetlands characteristic of the Central Appalachian region. We hypothesize that increased detection of metamorphs with increasing water temperature may be due to increases in activity levels (Moore and Townsend 1998), which increased the probability that metamorphs would encounter funnel traps. In modeling the abundance of green frogs based on calling data, Royle (2004b) found that detection probability increased with increasing water temperature due to an increase in calling activity. We believe that the decrease in detection probability from month to month for both species was due to metamorphs gradually leaving the wetland as they completed metamorphosis.

Our detection probability estimates for both species were quite low, and we offer 2 potential explanations. First, although binomial mixture models are one of the least biased estimators of detection (Wintle et al. 2004), our low estimates of $p$ may simply be an artifact of fitting models with a small dataset containing a large number of zeroes (MacKenzie and Royle 2005). Alternatively, our sampling design may not have been adequate to accurately detect such an ephemeral stage in amphibian life history in large wetland complexes such as ours. Church 
(2008) obtained detection probabilities ranging from 0.32 to 1.00 for metamorphs of multiple species, and Green et al. (2013) found a mean detection probability of 0.96 for wood frog metamorphs; both of these studies employed dipnetting around the perimeter of wetlands that were significantly smaller than wetlands in the present study. Metamorphs may be relatively rare both spatially and temporally. Survival to metamorphosis in natural populations of anurans is typically low (approximately 5\% for northern red-legged frog, Rana aurora [Calef 1973]; mean of $14.2 \%$ for American bullfrog [Cecil and Just 1979]), meaning that only a small portion of a population of anuran larvae throughout a wetland become metamorphs available for sampling, leading to spatial rarity. Metamorphs may be temporally rare because the metamorph stages (developmental stages 41-46 [Gosner 1960]) represent only 25\% of total development time (based on the Gulf Coast toad, Incilius valliceps [McDiarmid and Altig 1999]), which means that green frog and spring peeper metamorphs are available for sampling for only 18-90 days (based on 70-360 days for total development [Hulse et al. 2001]) and 23-25 days (based on 90-100 days [Hulse et al. 2001]), respectively. In light of this, it is not surprising that we captured few wood frogs and pickerel frogs, the metamorphs of which may only be available for 11-18 days (based on 42-70 days [Green and Pauley 1987]) and 18-23 days (based on 70-90 days [Hulse et al. 2001]), respectively. This spatial and temporal rarity most likely resulted in the violation of an assumption of N-mixture models (Royle 2004a), as the population of amphibian metamorphs was most likely not closed. A significant increase in sampling effort via number of traps deployed at each wetland and frequency of visits to wetlands may be required to increase detection probabilities, especially for species that transform quickly. 


\section{Larval Growth Rate and Survival}

The results from our laboratory study on the growth and survival of green frog larvae offer further support that the created wetlands in our study provide suitable conditions for successful reproduction. Poor water quality can negatively impact larval amphibian growth and survival (Jofre and Karasov 1999, Sanzo and Hecnar 2006), ultimately reducing reproductive success (Knutson et al. 2004). Claiming successful reproduction based solely on production of metamorphs could be misleading if larvae experienced depressed growth rates and hence smaller body size at metamorphosis. However, under controlled conditions, the tadpoles raised in water from created wetlands in our study exhibited similar survival, growth, and mean mass to tadpoles raised in water from natural wetlands. It is important to note, that although we fed tadpoles a consistent amount of food throughout the study, variable water quality and seasonal changes could affect the amount of food available to tadpoles in the wild. Depression in growth early in our study may have been due to density effects (Smith-Gill and Berven 1979), or may have been caused by initial stress related to laboratory conditions.

Considering that we recorded several anuran species vocalizing (during concurrent call surveys), we were surprised at the lack or paucity of metamorphs of those species captured in either the created or natural wetlands. Wood frogs often have high production in semi-permanent wetlands such as those in our study (Karraker and Gibbs 2009), yet we captured only a single wood frog metamorph during the entire study. The presence of predatory fish reduces both species richness and reproductive success of amphibians via predation on eggs and larvae (Porej and Hetherington 2005, Walston and Mullin 2007, Shulse et al. 2012). We detected (during funnel trapping and dipnetting) 4 species of fish in created (green sunfish, Lepomis cyanellus; bluegill, Lepomis macrochirus; smallmouth bass, Micropterus dolomieu; and bluntnose minnow, 
Pimephales notatus) and natural (chain pickerel, Esox niger; green sunfish; creek chub, Semotilus atromaculatus; and fallfish, Semotilus corporalis) wetlands, all of which are potential amphibian predators (Etnier and Starnes 1993, Stauffer et al. 1995). Natural wetlands often maintain variable hydroperiods which inhibit the establishment of fish populations, but created wetlands tend to exhibit more permanent hydroperiods (Cole and Brooks 2000), thus permitting fish establishment and excluding certain amphibians. Our use of beaver ponds as natural wetlands increased the probability that most if not all of our study wetlands contained fish. Most of the wetlands in our study also contained populations of red-spotted newts (Notophthalmus $v$. viridescens). The combined predation from fish and newts may be devastating to some amphibian species (Kurzava and Morin 1998).

Habitat generalists or species insensitive to disturbance such as the green frog (Walker 1946) and spring peeper (Gibbs 1998) may readily and successfully breed in created wetlands, whereas species with specific habitat requirements, such as wood frogs and spotted salamanders, may struggle due to pressure from predatory fish or other unsuitable habitat characteristics. More studies that focus on the adequacy of created wetlands to support specialist species are warranted (i.e., DiMauro and Hunter 2002, Petranka et al. 2007). Some amphibian species require habitat characteristics that created wetlands do not provide or take a very long time to develop; for example, in a study comparing created and natural wetlands in Kentucky, significantly fewer four-toed salamander (Hemidactylium scutatum) egg masses were found in created wetlands (King 2012). This species requires abundant moss for nesting, and in the Kentucky study, moss cover was reduced in created wetlands. 


\section{MANAGEMENT IMPLICATIONS}

Our study demonstrates that created wetlands can function as breeding habitat for generalist amphibians such as green frogs and spring peepers. To increase the functionality of created wetlands and provide breeding habitat for all local amphibians, wetlands should be designed to intentionally incorporate habitat features such as complex edges (Petranka et al. 2007, this study), shallow zones (Porej and Hetherington 2005), variable hydroperiod (Pechmann et al. 2001), heterogeneous surrounding landscape (Lesbarreres et al. 2010), and should be placed near other wetland habitat (Shulse et al. 2010). Future wetland creation must also necessarily account for climate change (e.g., by excavation of deep areas to ensure wetlands hold water long enough for larvae to metamorphose), as evidence is mounting that these changes affect the breeding phenology of adults (Daszak et al. 2005, Todd et al. 2011), with consequences for future generations (Orizaola et al. 2012).

\section{ACKNOWLEDGMENTS}

We thank A. M. J. Anderson, G. Albers, and D. Hartman for help in the field and laboratory. Funding and logistical support was provided by the WVU Division of Forestry and Natural Resources through the McIntire-Stennis program, the WVU Environmental Research Center, the National Oceanic and Atmospheric Administration, and a student research grant to GFS from the South Atlantic Chapter of the Society of Wetland Scientists. This is scientific article number XXXX of the WVU Agriculture and Forestry Experiment Station. 


\section{LITERATURE CITED}

Alford, R. A., and S. J. Richards. 1999. Global amphibian declines: a problem in applied ecology. Annual Review of Ecology and Systematics 30:133-165.

Balcombe, C. K., J. T. Anderson, R. H. Fortney, and W. S. Kordek. 2005a. Wildlife use of mitigation and reference wetlands in West Virginia. Ecological Engineering 25:85-99.

Balcombe, C. K., J. T. Anderson, R. H. Fortney, and W. S. Kordek. 2005b. Aquatic macroinvertebrate assemblages in mitigated and natural wetlands. Hydrobiologia $541: 175-188$.

Bledsoe, B. P., and T. H. Shear. 2000. Vegetation along hydrologic and edaphic gradients in a North Carolina Coastal Plain creek bottom and implications for restoration. Wetlands 20:126-147.

Brand, A. B., and J. W. Snodgrass. 2009. Value of artificial habitats for amphibian reproduction in altered landscapes. Conservation Biology 24:295-301.

Brinson, M. M. 1993. A hydrogeomorphic classification for wetlands. Wetland Research Program Technical Report WRP-DE-4, U. S. Army Corps of Engineers, Waterways Experiment Station, Vicksburg, MS, USA.

Brinson, M. M., and A. I. Malvarez. 2002. Temperate freshwater wetlands: types, status, and threats. Environmental Conservation 29:115-133.

Burnham, K.P., and D.R. Anderson. 2002. Model selection and multi-model inference. $2^{\text {nd }}$ ed. Springer, Berlin, Germany.

Byers, E. A., J. P. Vanderhorst, and B. P. Streets. 2007. Classification and conservation 
assessment of high elevation wetlands communities in the Allegheny Mountains of West Virginia. West Virginia Natural Heritage Program, West Virginia Division of Natural Resources, Elkins, WV, USA.

Calef, G. W. 1973. Natural mortality of tadpoles in a population of Rana aurora. Ecology $54: 741-758$.

Campbell, D. A., C. A. Cole, and R. P. Brooks. 2002. A comparison of created and natural wetlands in Pennsylvania, USA. Wetlands Ecology and Management 10:41-49.

Cecil, S. J., and J. J. Just. 1979. Survival rate, population density and development of a naturally occurring anuran larvae (Rana catesbeiana). Copeia 1979:447-453.

Chambers, R. M., and K. A. Pederson. 2006. Variation in soil phosphorus, sulfur, and iron pools among south Florida wetlands. Hydrobiologia 569:63-70.

Church, D.R. 2008. Role of current versus historical hydrology in amphibian species turnover within local pond communities. Copeia 2008:115-125.

Cole, C. A., and R. P. Brooks. 2000. A comparison of the hydrologic characteristics of natural and created mainstem floodplain wetlands in Pennsylvania. Ecological Engineering 14:221-231.

Cole, C. A., and D. Shafer. 2002. Section 404 wetland mitigation and permit success criteria in Pennsylvania, USA, 1986-1999. Environmental Management 30:508-515.

Cowardin, L. M., V. Carter, F. C. Golet, and E. T. LaRoe. 1979. Classification of wetland and deepwater habitats of the United States. FWS/OBS-79/31. U. S. Fish and Wildlife Service, Washington, D.C., USA.

Cunningham, J. M., A. J. K. Calhoun, and W. E. Glanz. 2007. Pond-breeding amphibian species 
richness and habitat selection in a beaver-modified landscape. Journal of Wildlife Management 71:2517-2526.

Dahl, T. E. 1990. Wetlands losses in the United States 1780's to 1980's. U. S. Department of the Interior, Fish and Wildlife Service, Washington, D. C., USA.

Dahl, T. E. 2006. Status and trends of wetlands in the conterminous United States 1998 to 2004. U. S. Department of the Interior, Fish and Wildlife Service, Washington, D. C., USA.

Dahl, T. E. 2011. Status and trends of wetlands in the conterminous United States 2004 to 2009. U. S. Department of the Interior, Fish and Wildlife Service, Washington, D. C., USA.

Dahl, T. E., and C. E. Johnson. 1991. Status and trends of wetlands in the conterminous United States, mid-1970’s to mid-1980’s. U. S. Department of the Interior, Fish and Wildlife Service, Washington, D.C., USA.

Daszak, P., D. E. Scott, A. M. Kilpatrick, C. Faggioni, J. W. Gibbons, and D. Porter. 2005. Amphibian population declines at Savannah River Site are linked to climate, not chytridiomycosis. Ecology 86:3232-3237.

Davic, R. D., and H. H. Welsh, Jr. 2004. On the ecological role of salamanders. Annual Review of Ecology, Evolution, and Systematics 35:405-434.

Diehl, J. W., and R. E. Behling. 1982. Geologic factors affecting formation and presence of wetlands in the north central section of the Appalachian Plateaus Province of West Virginia. Pages 3-9 in B. R. McDonald, editor. Proceedings of the symposium on wetlands of the unglaciated Appalachian region. West Virginia University, Morgantown, USA.

DiMauro, D., and M. L. Hunter. 2002. Reproduction of amphibians in natural and anthropogenic 
temporary pools in managed forests. Forest Science 48:397-406.

Environmental Protection Agency [EPA]. 2012. Wetlands and people.

< http://water.epa.gov/type/wetlands/people.cfm>. Accessed $10 \mathrm{Jul} 2013$.

Etnier, D. A., and W. C. Starnes. 1993. The fishes of Tennessee. The University of Tennessee Press, Knoxville, USA.

Francl, K. E., W. M. Ford, and S. B. Castleberry. 2004. Characterization of high elevation central Appalachian wetlands. Research Paper NE-725. U. S. Department of Agriculture, Forest Service, Northeastern Research Station, Newtown Square, Pennsylvania, USA.

Gallant, A. L., R. W., Klaver, G. S. Casper, and M. J. Lannoo. 2007. Global rates of habitat loss and implications for amphibian conservation. Copeia 2007:967-979.

Gibbons, J. W. 2003. Terrestrial habitat: a vital component for herpetofauna of isolated wetlands. Wetlands 23:630-635.

Gibbs, J. P. 1998. Distribution of woodland amphibians along a forest fragmentation gradient. Landscape Ecology 13:263-268.

Gingerich, R. T., and J. T. Anderson. 2011. Decomposition trends of five plant litter types in mitigated and reference wetlands in West Virginia, USA. Wetlands 31:653-662.

Gosner, K. L. 1960. A simplified table for staging anuran embryos and larvae with notes on identification. Herpetologica 16:183-190.

Green, A. W., N. B. Hooten, E. H. C. Grant, and L. L. Bailey. 2013. Evaluating breeding and metamorph occupancy and vernal pool management effects for wood frogs using a hierarchical model. Journal of Applied Ecology 50:1116-1123.

Green, N. B., and T. K. Pauley. 1987. Amphibians and reptiles in West Virginia. University of Pittsburgh Press, Pennsylvania, USA. 
Groffman, P. M., G. C. Hanson, E. Kiviat, and G. Stevens. 1996. Variation in microbial biomass and activity in four different wetland types. Soil Science Society of America Journal 60:622-629.

Halsey, L. 1997. Climatic and physiographic controls on wetland type and distribution in Manitoba, Canada. Wetlands 17:243-262.

Hossler, K., V. Bouchard, M. S. Fennessy, S. D. Frey, E. Anemaet, and E. Herbert. 2011. Nonet-loss not met for nutrient function in freshwater marshes: recommendations for wetland mitigation policies. Ecosphere 2:1-36.

Hulse, A. C., C. J. McCoy, and E. J. Censky. 2001. Amphibians and reptiles of Pennsylvania and the Northeast. Cornell University Press, Ithaca, New York, USA.

Jelinski, N. A., C. J. Kucharik, and J. B. Zedler. 2011. A test of diversity-productivity models in natural, degraded, and restored wet prairies. Restoration Ecology 19:186-193.

Jofre, M. B., and W. H. Karasov. 1999. Direct effect of ammonia on three species of North American anuran amphibians. Environmental Toxicology and Chemistry 18:1806-1812.

Karraker, N. E., and J. P. Gibbs. 2009. Amphibian production in forested landscapes in relation to wetland hydroperiod: a case study of vernal pools and beaver ponds. Biological Conservation 142:2293-2302.

Kery, M., R. M. Dorazio, L Soldaat, A. van Strien, A. Zuiderwijk, and J. A. Royle. 2009. Trend estimation in populations with imperfect detection. Journal of Applied Ecology 46:11631172.

King, S. K. 2012. Four-toed salamander (Hemidactylium scutatum) nest site characteristics in natural and constructed wetlands in eastern Kentucky. Thesis, Eastern Kentucky University, Richmond, USA. 
Knutson, M. G., W. B. Richardson, D. M. Reineke, B. R. Gray, J. R. Parmelee, and S. E. Weick. 2004. Agricultural ponds support amphibian populations. Ecological Applications $14: 669-684$.

Kurzava, L. M., and P. J. Morin. 1998. Tests of functional equivalence: complementary roles of salamanders and fish in community organization. Ecology 79:477-489.

Lesbarreres, D., M. S. Fowler, A. Pagano, and T. Lode. 2010. Recovery of anuran community diversity following habitat replacement. Journal of Applied Ecology 47:148-156.

MacKenzie, D. I., and W. L. Kendall. 2002. How should detection probability be incorporated into estimates of relative abundance? Ecology 83:2387-2393.

MacKenzie, D. I., J. D. Nichols, G. B. Lachman, S. Droege, J. A. Royle, and C. A. Langtimm. 2002. Estimating site occupancy when detection probabilities are less than one. Ecology $83: 2248-2255$.

MacKenzie, D. I., and J. A. Royle. 2005. Designing occupancy studies: general advice and allocating survey effort. Journal of Applied Ecology 42:1105-1114.

Marsh, D. M., and P. C. Trenham. 2001. Metapopulation dynamics and amphibian conservation. Conservation Biology 15:40-49.

McCune, B., and J. B. Grace. 2002. Analysis of ecological communities. MJM Software Design, Gleneden Beach, Oregon, USA.

McDiarmid, R. W., and R. Altig. 1999. Research: materials and methods. Pages 7-23 in R. W. McDiarmid, and R. Altig, editors. Tadpoles: the biology of anuran larvae. The University of Chicago Press, Illinois, USA.

Micacchion, M. 2002. Amphibian index of biotic integrity (AmphIBI) for wetlands. Final 
report to U. S. EPA Grant No. CD985875-01. Ohio Environmental Protection Agency. Wetland Ecology Group, Division of Surface Water, Columbus, USA.

Mitsch, W. J., and J. G. Gosselink. 2007. Wetlands. $4^{\text {th }}$ ed. Wiley and Sons, Hoboken, New Jersey, USA.

Moore, M. K., and V. R. Townsend, Jr. 1998. The interaction of temperature, dissolved oxygen and predation pressure in an aquatic predator-prey system. Oikos 81:329-336.

Naiman, R. J., C. A. Johnston, and J. C. Kelley. 1988. Alteration of North American streams by beaver. BioScience 38:753-762.

Nichols, J. D. 1992. Capture-recapture models: using marked animals to study population dynamics. BioScience 42:92-102.

Orizaola, G., E. Dahl, A. G. Nicieza, and A. Laurila. 2012. Larval life history and anti-predator strategies are affected by breeding phenology in an amphibian. Oecologia 171:873-881.

Pauley, T. K. 2000. Amphibians and reptiles in wetland habitats of West Virginia. Proceedings of the West Virginia Academy of Sciences 72:78-88.

Pearl, C. A., and J. Bowerman. 2006. Observations of rapid colonization of constructed ponds by western toads (Bufo boreas) in Orgeon, USA. Western North American Naturalist 66:397-401.

Pechmann, J. H. K., R. A. Estes, D. E. Scott, and J. W. Gibbons. 2001. Amphibian colonization and use of ponds created for trial mitigation of wetland loss. Wetlands 21:93-111.

Petranka, J. W., E. M. Harp, C. T. Holbrook, and J. A. Hamel. 2007. Long-term persistence of amphibian populations in a restored wetland complex. Biological Conservation 138:371380.

Petranka, J. W., S. S. Murray, and C. A. Kennedy. 2003. Responses of amphibians to 
restoration of a southern Appalachian wetland: perturbations confound post-restoration assessment. Wetlands 23:278-290.

Phillips, K. 1990. Where have all the frogs and toads gone? BioScience 40:422-424.

Pope, S. E., L. Fahrig, and H. G. Merriam. 2000. Landscape complementation and metapopulation effects on leopard frog populations. Ecology 81:2498-2508.

Porej, D., and T. E. Hetherington. 2005. Designing wetlands for amphibians: the importance of predatory fish and shallow littoral zones in structuring of amphibian communities. Wetlands Ecology and Management 13:445-455.

Richter, S. C., J. E. Young, G. N. Johnson, and R. A. Seigel. 2003. Stochastic variation in reproductive success of a rare frog, Rana sevosa: implications for conservation and for monitoring amphibian populations. Biological Conservation 111:171-177.

Robinson, G. G. C., S. E. Gurney, and L. G. Goldsborough. 1997. The primary productivity of benthic and planktonic algae in a prairie wetland under controlled water-level regimes. Wetlands 17:182-194.

Royle, J. A. 2004a. N-mixture models for estimating population size from spatially replicated counts. Biometrics 60:108-115.

Royle, J. A. 2004b. Modeling abundance index data from anuran calling surveys. Conservation Biology 18:1378-1385.

Sanzo, D., and S. J. Hecnar. 2006. Effects of road de-icing salt ( $\mathrm{NaCl})$ on larval wood frogs (Rana sylvatica). Environmental Pollution 140:247-256.

Schlaepfer, M. A., M. C. Runge, and P. W. Sherman. 2002. Ecological and evolutionary traps. Trends in Ecology and Evolution 17:474-480.

Schmidt, B.R. 2003. Count data, detection probabilities, and the demography, dynamics, 
distribution, and decline of amphibians. Comptes Rendus Biologies 326:119-124.

Semlitsch, R. D., and J. R. Bodie. 1998. Are small, isolated wetlands expendable? Conservation Biology 12:1129-1133.

Shaffer, P. W., M. E. Kentula, and S. E. Gwin. 1999. Characterization of wetland hydrology using hydrogeomorphic classification. Wetlands 19:490-504.

Shulse, C. D., R. D. Semlitsch, K. M. Trauth, and J. E. Gardner. 2012. Testing wetland features to increase amphibian reproductive success and species richness for mitigation and restoration. Ecological Applications 22:1675-1688.

Shulse, C. D., R. D. Semlitsch, K. M. Trauth, and A. D. Williams. 2010. Influences of design and landscape placement parameters on amphibian abundance in constructed wetlands. Wetlands 30:915-928.

Skelly, D. K. 1994. Activity level and the susceptibility of anuran larvae to predation. Animal Behavior 47:465-468.

Skelly, D. K. 1995. Competition and the distribution of spring peeper larvae. Oecologia 103:203-207.

Smith-Gill, S. J., and K. A. Berven. 1979. Predicting amphibian metamorphosis. American Naturalist:113:563-585.

Stauffer, J. R., Jr., J. M. Boltz, and L. R. White. 1995. The fishes of West Virginia. Academy of Natural Sciences of Philadelphia, Pennsylvania, USA.

Strain, G. F., T. K. Pauley, and J. T. Anderson. 2013. Visible implant alphanumeric tag retention in green frog (Lithobates clamitans) tadpoles. Herpetological Review 44:440442.

Tiner, R. W. 2002. In search of swampland. A wetlands sourcebook and field guide. 


\section{Rutgers University Press, New Brunswick, New Jersey, USA.}

Todd, B. D., D. E. Scott, J. H. K. Pechmann, and J. W. Gibbons. 2011. Climate change correlates with rapid delays and advancements in reproductive timing in an amphibian community. Proceedings of the Royal Society 278:2191-2197.

Trenham, P. C., W. D. Koenig, M. J. Mossman, S. L. Stark, and L. A. Jagger. 2003. Regional dynamics of wetland-breeding frogs and toads: turnover and synchrony. Ecological Applications 13:1522-1532.

Turner, R. E., A. M. Redmond, and J. B. Zedler. 2001. Count it up by acre or function mitigation adds up to net loss of wetlands. National Wetlands Newsletter 23:5-16.

Vannote, R. L., G. W. Minshall, K. W. Cummins, J. R. Sedell, and C. E. Cushing. 1980. The river continuum concept. Canadian Journal of Fisheries and Aquatic Sciences 37:130 137.

Walker, C. F. 1946. The amphibians of Ohio. Part 1. The frogs and toads. Ohio State Museum Science Bulletin 1, Columbus, OH, USA.

Walston, L. J., and S. J. Mullin. 2007. Responses of a pond-breeding amphibian community to the experimental removal of predatory fish. American Midland Naturalist 157:63-73.

Weakley, A. S., and M. P. Schafale. 1994. Non-alluvial wetlands of the Southern Blue Ridge - diversity in a threatened ecosystem. Water, Air and Soil Pollution 77:359-383.

Whigham, D. F. 1999. Ecological issues related to wetland preservation, restoration, creation and assessment. Science of the Total Environment 240:31-40.

Wintle, B. A., M. A. McCarthy, K. M. Parris, and M. A. Burgman. 2004. Precision and bias of methods for estimating point survey detection probabilities. Ecological Applications $14: 703-712$. 
Yoccoz, N. G., J. D. Nichols, and T. Boulinier. 2001. Monitoring of biological diversity in space and time. Trends in Ecology and Evolution 16:446-453.

Zedler, J. B. 1996. Ecological issues in wetland mitigation: an introduction to the forum.

Ecological Applications 6:33-37.

Associate Editor: 
Table 1. Attributes of natural $(n=6)$ and created $(n=6)$ wetlands used to study amphibian reproductive success in the Central Appalachians. Size refers to the area of the inundated basin of each wetland and complexity was calculated as $\left(\mathrm{m} / \sqrt{\mathrm{m}}^{2}\right)$.

Hydrogeomorphic (HGM) and Cowardin wetland classifications were based on Brinson (1993) and Cowardin et al. (1979), respectively.

\begin{tabular}{|c|c|c|c|c|c|c|c|c|c|}
\hline Wetland & Type & Pair & $\begin{array}{l}\text { Year } \\
\text { Built }\end{array}$ & $\begin{array}{l}\text { Size } \\
\text { (ha) }\end{array}$ & County & $\begin{array}{l}\text { Elevation } \\
\quad(\mathrm{m})\end{array}$ & Geology & Complexity & HGM/Cowardin Classification \\
\hline Camp 70 & Natural & 1 & -- & 0.02 & Tucker, WV & 952 & Shale & 4.14 & $\begin{array}{l}\text { Riverine, beaver-impounded/Palustrine } \\
\text { unconsolidated shore vegetated }\end{array}$ \\
\hline Elk Run & Created & 1 & 1981 & 3.8 & Grant, WV & 840 & Shale & 6.31 & $\begin{array}{l}\text { Riverine, human-impounded/Palustrine } \\
\text { unconsolidated bottom organic }\end{array}$ \\
\hline Garrett State Forest & Natural & 2 & -- & 2.0 & Garrett, MD & 760 & Sandstone & 7.48 & $\begin{array}{l}\text { Riverine, beaver-impounded/Palustrine } \\
\text { unconsolidated shore vegetated }\end{array}$ \\
\hline Everhart Seep & Created & 2 & 2000 & 0.27 & Garrett, MD & 812 & Sandstone & 4.68 & $\begin{array}{c}\text { Depression, human-excavated/Palustrine } \\
\text { emergent persistent }\end{array}$ \\
\hline Glade Run & Natural & 3 & -- & 2.0 & Tucker, WV & 962 & Limestone & 4.49 & $\begin{array}{c}\text { Riverine, beaver-impounded/Palustrine } \\
\text { emergent persistent }\end{array}$ \\
\hline VEPCO & Created & 3 & 1995 & 7.0 & Tucker, WV & 1036 & Sandstone & 4.04 & $\begin{array}{c}\text { Riverine, human-impounded/Palustrine } \\
\text { moss-lichen }\end{array}$ \\
\hline Upper Deckers & Natural & 4 & -- & 2.6 & Preston, WV & 512 & Sandstone & 5.81 & $\begin{array}{c}\text { Riverine, lower perennial/Palustrine } \\
\text { aquatic bed floating vascular }\end{array}$ \\
\hline Leading Creek & Created & 4 & 1995 & 8.6 & $\begin{array}{l}\text { Randolph, } \\
\text { WV }\end{array}$ & 600 & Alluvium & 5.25 & $\begin{array}{c}\text { Riverine, human-impounded/Palustrine } \\
\text { emergent persistent }\end{array}$ \\
\hline Old Fields & Natural & 5 & -- & 4.0 & Hardy, WV & 292 & Shale & 6.05 & $\begin{array}{l}\text { Riverine, non-perennial/Palustrine } \\
\text { emergent persistent }\end{array}$ \\
\hline Walnut Bottom & Created & 5 & 1997 & 10.0 & Hardy, WV & 335 & Shale & 5.60 & $\begin{array}{l}\text { Riverine, human-impounded/Palustrine } \\
\text { emergent persistent }\end{array}$ \\
\hline Rail Trail & Natural & 6 & -- & 4.1 & Preston, WV & 525 & Shale & 4.41 & $\begin{array}{l}\text { Riverine, upper perennial/Palustrine } \\
\text { forested broad-leaved deciduous }\end{array}$ \\
\hline Sugar Creek & Created & 6 & 1995 & 6.8 & Barbour, WV & 478 & Sandstone & 4.03 & $\begin{array}{l}\text { Riverine, human-impounded/Palustrine } \\
\text { emergent persistent }\end{array}$ \\
\hline
\end{tabular}


Table 2. Number of amphibian metamorphs of each species encountered in created and natural wetlands of the Central Appalachians during 2009 and 2010, with estimated detection probability $(\hat{p})$ and $95 \%$ confidence interval for $p$ for species with adequate data.

\begin{tabular}{|c|c|c|c|c|c|c|}
\hline \multirow[b]{2}{*}{ Species } & \multicolumn{2}{|c|}{ Created Wetlands } & \multicolumn{2}{|c|}{ Natural Wetlands } & \multirow[b]{2}{*}{$\hat{p}$} & \multirow[b]{2}{*}{$95 \% \mathrm{CI}$} \\
\hline & 2009 & 2010 & 2009 & 2010 & & \\
\hline American bullfrog & 0 & 1 & 0 & 0 & -- & -- \\
\hline Cope's gray/gray treefrog & 0 & 7 & 0 & 0 & -- & -- \\
\hline Green frog & 25 & 16 & 9 & 20 & 0.008 & $0.004,0.018$ \\
\hline Pickerel frog & 0 & 0 & 2 & 3 & -- & -- \\
\hline Spotted salamander & 1 & 1 & 1 & 3 & -- & -- \\
\hline Spring peeper & 24 & 10 & 21 & 2 & 0.07 & $0.01,0.33$ \\
\hline Wood frog & 0 & 1 & 0 & 0 & -- & -- \\
\hline
\end{tabular}


Table 3. Estimates and $95 \%$ confidence intervals for abundance and detection parameters used in binomial mixture models describing the abundance of spring peeper and green frog metamorphs encountered in created and natural wetlands of the Central Appalachians during 2009 and 2010 (-- indicates that a parameter was not in the final model for that species).

\begin{tabular}{|c|c|c|c|c|c|c|c|}
\hline \multirow[b]{2}{*}{ Parameter } & \multirow[b]{2}{*}{ Sub-model } & \multicolumn{3}{|c|}{ Spring peeper } & \multicolumn{3}{|c|}{ Green frog } \\
\hline & & Estimate & SE & $p$-value & Estimate & SE & $p$-value \\
\hline Year & Abundance & -1.94 & 0.50 & $<0.001$ & -- & -- & -- \\
\hline Habitat complexity & Abundance & -- & -- & -- & 1.43 & 0.40 & $<0.001$ \\
\hline Water temperature & Detection & 1.58 & 0.80 & $<0.001$ & 0.89 & 0.14 & $<0.001$ \\
\hline Month & Detection & -2.39 & 0.54 & $<0.001$ & -0.43 & 0.15 & 0.004 \\
\hline
\end{tabular}




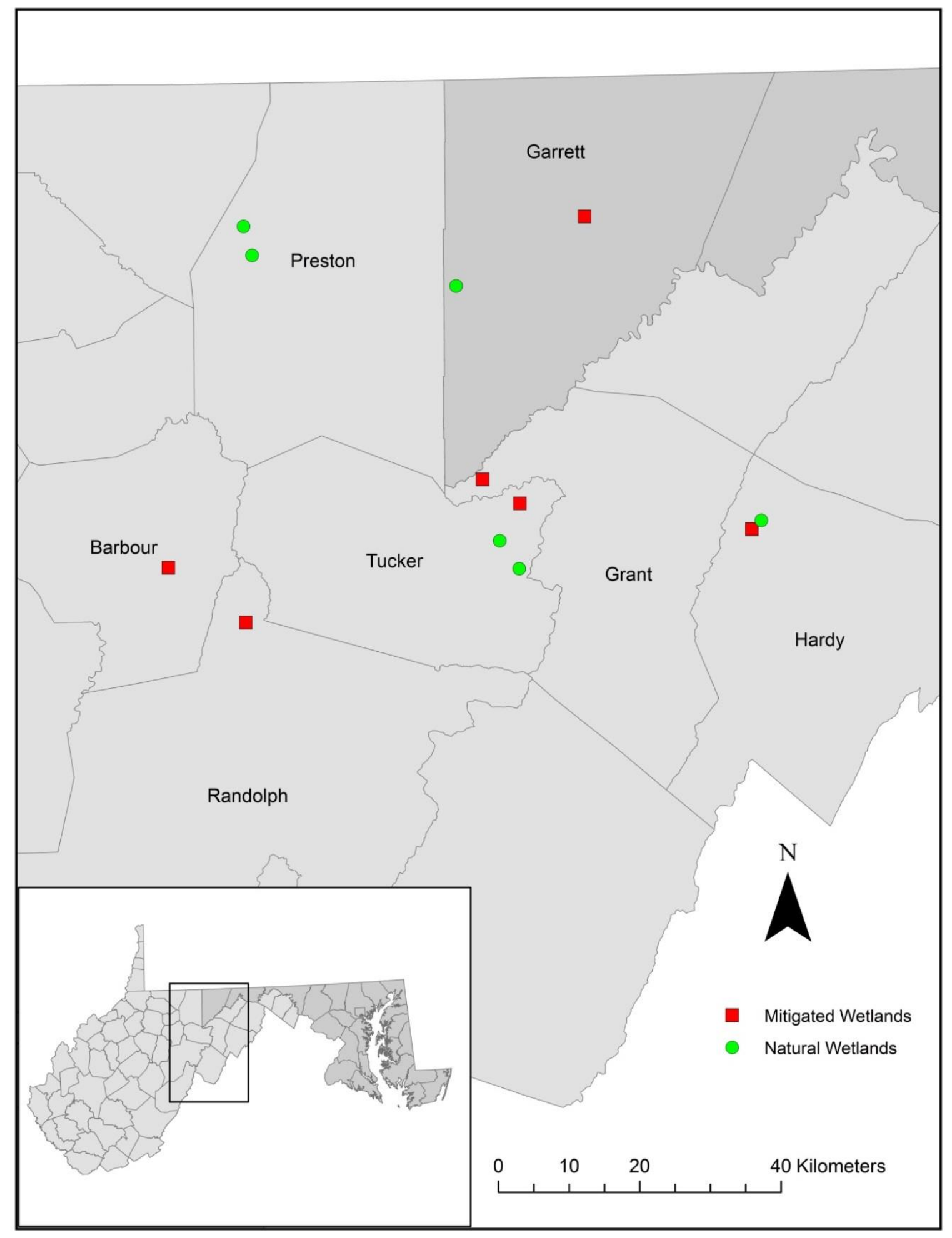

Figure 1. Locations of natural $(n=6)$ and created $(n=6)$ wetlands used to study amphibian reproductive success in the Central Appalachians, West Virginia and Maryland. 


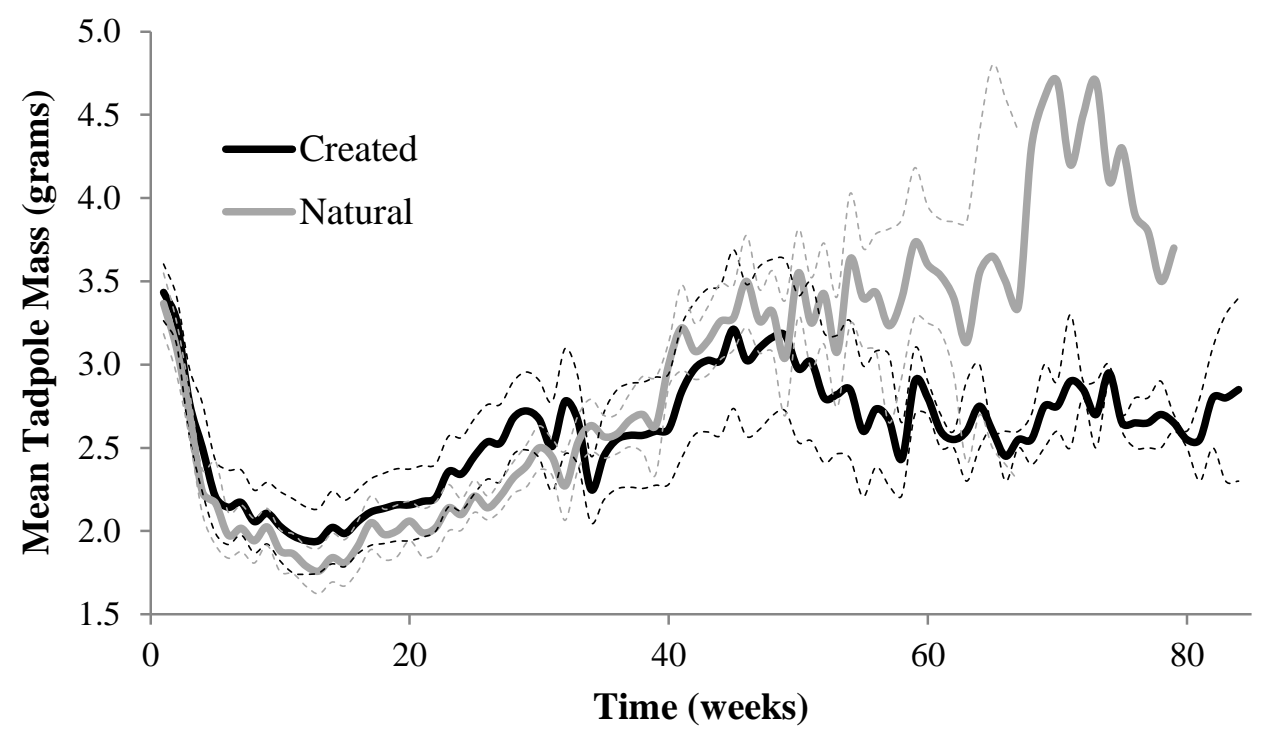

Figure 2. Mean mass of green frog tadpoles raised in water from created and natural wetlands of the Central Appalachians (dashed lines represent naive +/- $1 \mathrm{SE}$; SE lines for natural wetlands truncated because tadpoles from only 1 wetland survived beyond week 67). 


\title{
CHAPTER III
}

\section{AMPHIBIAN OCCUPANCY OF CREATED WETLANDS IN THE CENTRAL} APPALACHIANS: A TEST OF FUNCTIONAL EQUIVALENCE

\author{
Gabriel F. Strain ${ }^{1 *}$, Philip J. Turk ${ }^{2}$, Andrew $\operatorname{Tri}^{1}{ }^{1}$, and James T. Anderson ${ }^{1,3}$ \\ ${ }^{1}$ West Virginia University, Division of Forestry and Natural Resources, PO Box 6125, \\ Morgantown, WV 26506-6125 \\ *Corresponding Author e-mail: gstrain54@yahoo.com \\ ${ }^{2}$ West Virginia University, Department of Statistics, \\ PO Box 6330, Morgantown, WV 26506-6125 \\ ${ }^{3}$ West Virginia University, Environmental Research Center, Morgantown, USA
}

Written in the style of:

Biological Conservation 


\title{
Amphibian occupancy of created wetlands in the Central Appalachians: a test of functional equivalence
}

\author{
G.F. Strain ${ }^{* 1}$, P.J. Turk ${ }^{2}$, A. Tri $^{1}$ and J.T. Anderson ${ }^{1,3}$ \\ ${ }^{1}$ Division of Forestry and Natural Resources, West Virginia University, \\ Morgantown, USA \\ ${ }^{2}$ Department of Statistics, West Virginia University, Morgantown, USA \\ ${ }^{3}$ West Virginia University, Environmental Research Center, Morgantown, USA \\ *Corresponding author: gstrain54@yahoo.com
}

\begin{abstract}
Evaluating the adequacy of created wetlands to replace the functions of lost natural wetlands is important because wetland mitigation is a major tool used to offset wetland losses. However, measurements such as vegetative cover and presence of wildlife may not provide sufficient evidence that created wetlands are functioning properly and thus examining the ecology of wetland biota such as that of amphibians may be a more useful surrogate for function. The objectives of this study were to compare the occupancy and detection of calling anurans in created wetlands relative to natural wetlands. We performed five-minute, ten-minute, and broadcast call surveys at 24 wetlands throughout the Central Appalachians once every month from March through August of 2009 and 2010. We used occupancy modeling to estimate the occupancy and detection of individual species, incorporating relevant environmental variables.
\end{abstract}


The occupancy of individual anuran species did not differ between created and natural wetlands. Detection of anurans was largely unaffected by call survey type, but several environmental covariates had a significant effect on the detectability of calling anurans. Our results suggest that the function of providing adequate breeding habitat for adult anurans is being fulfilled by the created wetlands that we examined.

\section{Introduction}

Wetlands provide important ecosystem services (Mitsch and Gosselink 2007) including the provision of vital habitat to both wildlife and plants (Dahl and Johnson 1991, Balcombe et al. 2005a). Over one third of federally endangered or threatened plants and animals rely on wetlands (Dahl and Johnson 1991, EPA 2012), including amphibians. Many amphibian species depend on wetlands and spend all or part of their life cycle in them because wetlands are excellent sources of food, protection, and breeding opportunities (Gibbons 2003). In West Virginia, 22 species of amphibians are considered wetland obligates (Pauley 2000).

However, wetland loss throughout United States history has been severe (Whigham 1999, Brinson and Malvarez 2002). Of the original 89.5 million ha of wetlands in the conterminous United States (circa 1780), approximately 47.3 million ha (53\%) have been lost (Dahl 1990); the United States continues to lose 116,000 ha per year (Dahl 2006). The destruction or alteration of wetland habitats, including the surrounding terrestrial landscape (Pope et al. 2000, Marsh and Trenham 2001), may just be one of the many factors contributing to the current global decline of amphibian populations (Phillips 1990, Alford and Richards 1999). Wetland loss threatens the biodiversity of amphibians through outright habitat destruction and loss of wetland connectivity (Semlitsch and Bodie 1998, Gallant et al. 2007). 
Compensatory mitigation has been the primary tool used to accomplish the long-standing policy of "no net loss" of wetlands (Zedler 1996, Turner et al. 2001). Avoidance of wetland impacts is preferred, but compensatory mitigation, the replacement or compensation of wetland area and function, is used when permitted damage to natural wetlands is unavoidable (Zedler 1996, Cole and Shafer 2002). The success of wetland mitigation is equivocal because, although recent studies demonstrate that emergent and scrub-shrub wetlands have increased in area in the United States, losses outweigh gains in overall wetland area (Dahl 2011), and evidence suggests that certain functions such as nutrient cycling are not being adequately mitigated (Hossler et al. 2011).

The success of created wetlands is typically judged by examining parameters such as hydrology, vegetative cover, or the presence of wildlife; however, similar structure or species lists of a created wetland to a lost wetland does not necessarily mean that the created wetland functions in the same way (Campbell et al. 2002, Jelinski et al. 2011). Therefore, assessment of the functions that created wetlands provide, such as provision of habitat for amphibians, may be a more suitable approach.

Balcombe et al. (2005a, 2005b, 2005c) used vegetation and wildlife parameters and rankings as surrogates for function, including call survey data for anurans. They found that created wetlands in West Virginia supported the same seven species of amphibians that reference sites did, and that Wisconsin call index values and relative abundance of calling anurans were higher in mitigated wetlands for some species (Balcombe et al. 2005a). However, inferences based on raw counts of species or call indices will be biased unless detection probability, which is most likely less than one, is taken into account (MacKenzie et al. 2006). Occupancy modeling is a technique that has been developed in recent years which allows researchers to make reliable 
inferences about species, such as amphibians, which are not always detected perfectly (Pellet and Schmidt 2005). Assessment of the use of created wetlands by breeding anurans while simultaneously accounting for imperfect detection is important to facilitate determination of the adequacy of created wetlands as functional replacements of natural wetlands.

Call surveys are widely used because they provide species lists and approximations of breeding activity (Zimmerman 1994, Weir et al. 2005), and can be performed quickly and easily, often with the help of volunteers (Genet and Sargent 2003). However, standard call surveys may not detect some species because the surveys are performed for a limited period of time and easily disturbed species may not call during the survey (Bridges and Dorcas 2000). Therefore, alternative survey methods such as broadcasting advertisement calls and increasing the length of surveys may yield improved results.

Imperfect detection of calling anurans can severely bias estimates of occupancy, trends, or comparisons between experimental or observational treatments, because failure to detect species that are present results in false absences (Yoccoz et al. 2001, MacKenzie et al. 2002). This problem can be demonstrated with the formula

$$
E(C)=N p,
$$

where $E(C)$ is the expected value of a count of individuals, $N$ is the true number of individuals, and $p$ is the detection probability (Nichols 1992). The estimate of $N$ is a function of both the count $C$ and the detection probability $p$. Comparisons between counts taken at multiple times or sites $\left(C_{1} / C_{2}\right)$ are only reliable if $p$ is constant between sampling times or sites (Yoccoz et al. 2001). Researchers have often either ignored or attempted to minimize variation in detection probability by using standardized methods, but in reality the assumption of constant detection probabilities is rarely if ever met (Yoccoz et al. 2001, MacKenzie and Kendall 2002). Detection 
probability may be affected by multiple factors such as weather conditions, habitat variability, sampling techniques, and observer experience. To make reliable inferences it is important to partition variation in detection from variation in the variable of interest, such as site occupancy. Over the past decade, numerous methods have been developed that deal with imperfect detection, such as binomial mixture models which estimate abundance while simultaneously incorporating estimates of detection (Royle 2004). Thus, the specific objectives of this study were to account for variable detection in the comparison of the use of created and natural wetlands by breeding anurans and at the same time examine factors affecting the detection of encountered species. The secondary objective was to compare the efficacy of conducting typical five-minute manual call surveys (NAAMP 2005), manual call surveys of double that length (i.e., ten minutes), and broadcast calls.

\section{Methods}

Study Area

Twelve created $(\overline{\mathrm{x}}=4.8 \mathrm{ha}, \mathrm{SE}=0.9)$ and 12 natural $(\overline{\mathrm{x}}=3.1$ ha, $\mathrm{SE}=0.5)$ wetlands were selected for study (Fig. 1, Table 1). The majority of the created wetlands used in this study were constructed by the West Virginia Division of Highways to offset losses to natural wetlands during the construction of two major highways (Gingerich and Anderson 2011). Excavated wetland basins were lined with clay and topsoil, and seeded and planted with herbaceous and woody plant species. The majority of created wetlands in West Virginia and other states tend to be dominated by open water compared to natural wetlands (Cole and Brooks 2000, Balcombe et al. 2005d). Historic beaver (Castor canadensis)-created wetlands tend to be dominated by open water (Naiman et al. 1988) and thus may approximate the conditions of created wetlands as 
amphibian habitat more so than other wetland types in the state. We thus selected beaver ponds as natural wetlands. We determined the approximate size (ha) and perimeter (m) of each wetland from aerial photographs using ArcMap 10.0 (ESRI, Redlands, CA).

Call surveys

Call surveys were performed at each site once every month from March through August of 2009 and 2010. Surveys consisted of observers visiting each wetland between 30 minutes after sunset and one a.m. (NAAMP 2005). Observers observed a three-minute waiting period to allow for any possible disturbance their arrival may have caused (Mannan 2008). Following the waiting period, a five-minute call survey, ten-minute call survey, and a broadcast call survey (one for each species, see below) were performed in a randomized sequence near the center of each wetland. Broadcast calls consisted of broadcasting the call of each species in a randomized sequence for one minute via an $\mathrm{mp} 3$ player attached to speakers followed by a three-minute listening period (Mannan 2008). We observed a three-minute waiting period between each survey (for both manual surveys and the broadcasts for each species) to allow for possible disturbance or activity due to the previous survey (Mannan 2008) and reasonably claim independence between call survey methods. All calling anurans were identified to species, and to satisfy the requirements for occupancy modeling each species was recorded as detected (1) or not detected (0). Observers recorded air temperature, relative humidity, and wind speed with a Kestrel 3000 pocket wind meter (Nielsen-Kellerman, Boothwyn, PA), water temperature with a standard thermometer, and percent cloud cover by visual estimation. Julian Day was calculated as 1 on the first of January and 365 on December 31 . To compare against modeled estimates of 
occupancy, we calculated naïve occupancy estimates by dividing the number of wetlands where a species was detected at least once by the total number of wetlands.

\section{Statistical Analysis}

Calling anurans are most likely not detected perfectly and analyses based on raw count data would be slightly or moderately biased. Occupancy models have been developed which estimate the proportion of sites occupied by a specific species while simultaneously incorporating estimates of detection probability (MacKenzie et al. 2002). We used a hierarchical modeling framework which involves the joining of two generalized linear models; a sub-model that characterizes site occupancy $(\Psi)$, and a sub-model that characterizes detection probability $(p)$ (Fiske and Chandler 2011). We fitted occupancy models to the detection histories of eight anuran species that we encountered across two, three, or four sampling occasions for each of two years. If a species was not detected at any of the 24 sites during a given sampling occasion, it was assumed that individuals were most likely not available to be sampled; therefore, we removed those occasions and restricted our analysis to sampling periods where a particular species was observed in at least one wetland. Air temperature, water temperature, percent cloud cover, relative humidity, wind speed, and Julian day were standardized to a mean of zero and standard deviation of one.

To model occupancy we used a logistic model (logit-link) in which occupancy $\Psi$ varied as a function of wetland type (created or natural), and year (2009 or 2010). To keep models as simple as possible, we did not include other habitat variables that might affect occupancy. We used the logit link to model detection probability $p$ as a function of call survey method (tenminute, five-minute, or broadcast), air temperature, water temperature, percent cloud cover, 
relative humidity, wind speed, and Julian day. We modeled all possible combinations of detection covariates with both occupancy terms (wetland type and year) included in every model; we included a null model (containing only intercept terms for both sub-models). To keep models as parsimonious as possible and minimize the number of models in each set, we did not include interaction terms. We estimated model parameters with maximum likelihood estimation using the "unmarked" package in the freely downloadable software package R (version 2.15.2). We selected the model that best fit the data via Akaike's Information Criterion (AIC); models within two AIC units of the model with the smallest AIC were considered well-supported (Burnham and Anderson 2002), and we selected the most parsimonious model as our final model. To test each variable in the final model (at a significance value of 0.05), we used likelihood ratio tests (survey method) or Wald tests (wetland type, year, air temperature, water temperature, cloud cover, relative humidity, wind speed, and Julian day). We computed confidence intervals for odds ratios for wetland type, year, and detection explanatory variables. We assessed the fit of each final model versus the null model with a likelihood ratio test.

To compare anuran species richness between created and natural wetlands, we used binomial mixture models, which estimate abundance (or in our case species richness) while simultaneously incorporating estimates of detection probability (Royle 2004). Similar to occupancy models, binomial mixture models involve the joining of two generalized linear models; a sub-model that characterizes local abundance $(N)$, and a sub-model that characterizes detection probability ( $p$ ) (Kery et al. 2009). We fitted Royle's model to the total number of species $N$ recorded during five-minute call surveys from 24 wetlands across five sampling occasions for each of two years. Air temperature, water temperature, percent cloud cover, relative humidity, wind speed, and Julian day were standardized to a mean of zero and standard 
deviation of 1 . To model species richness, we used a log-linear model in which the log of expected $N$ varied as a function of wetland type (created or natural) and year. We used the logistic model (logit link) to model detection probability $p$ as a function of air temperature, water temperature, percent cloud cover, relative humidity, wind speed, and Julian day. For this analysis, we assumed that detection probabilities were constant across species (most likely an erroneous assumption, but we believed it was important to account for imperfect detection as much as possible). We modeled all possible combinations of detection terms, including a null model (containing only intercept terms for both sub-models); both species richness factors (wetland type and year) were kept in all models. We used three distributions for $N$ (Poisson, zero-inflated Poisson, and negative binomial) for each model, for a total of 192 models. Model parameters were estimated via maximum likelihood estimation using the "unmarked" package in the freely downloadable software package $\mathrm{R}$ (version 2.15.2). We selected the model that best fit the data via Akaike's Information Criterion (AIC). Models within two AIC units of the model with the smallest AIC were considered well-supported (Burnham and Anderson 2002), and we selected the most parsimonious model as our final model. To test each variable in the final model (at a significance value of 0.05 ), we used Wald tests. We estimated the pooled detection probability and obtained a confidence interval estimate at mean relevant covariate values. We used parametric bootstrapping for a goodness-of-fit test (Dixon 2002) and a likelihood ratio test to assess the fit of the final model versus the null model.

\section{Results}

A total of 11 species were detected; 11 species were detected in created wetlands and nine were detected in natural wetlands. Two species (eastern cricket frog, Acris crepitans, and upland 
chorus frog, Psuedacris feriarum) with more coastal distributions were only detected at sites on or near West Virginia's eastern panhandle and were thus omitted from analysis. Fowler's toad (Anaxyrus fowleri) was detected at a single site in 2010 and was also omitted from analysis. The results are discussed below individually for each of the eight species for which we obtained sufficient data for analyses.

\section{American Toad (Anaxyrus americanus)}

The best model describing occupancy of American toads contained wind speed and Julian day. Wetland type and year were not significant (Table 2); occupancy of American toads was similar between created and natural wetlands and between 2009 and 2010. Julian day and wind speed significantly affected detection of American toads, but in opposite directions: detection probability increased with wind speed $(z=2.39, p=0.017$, Fig. 2$)$ and decreased over time $(z=$ $-6.76, p<0.001$, Fig. 3). In terms of odds ratios (derived by exponentiating the parameter estimates), the odds of detecting American toads was estimated to be $1.4(95 \%$ C.I. $=1.1,1.8)$ times greater with every standardized unit increase in wind speed. The odds of detecting American toads was estimated to be $0.6(95 \%$ C.I. $=0.5,0.7)$ times less for every standardized unit increase in Julian day. A likelihood ratio test did not support the inclusion of survey method in the final model $\left(X_{2}^{2}=0.40, P=0.82\right)$; estimates of detection probability were similar between five-minute, ten-minute, and broadcast surveys. We compared the final model against the null model with a likelihood ratio test to confirm the explanatory capability of the terms contained in the model; the final model had significant explanatory capability $\left(X^{2}{ }_{6}=63.57, P<0.001\right)$. 


\section{Cope's Gray Treefrog (Hyla chrysoscelis)}

The best model describing occupancy of Cope's gray treefrogs contained air temperature, cloud cover, wind speed and Julian day. Effects on occupancy were similar across wetland types and years (Table 2). Detection probability of Cope's gray treefrogs increased with air temperature $(z$ $=3.52, p<0.001$, Fig. 4) and cloud cover $(z=3.83, p<0.001$, Fig. 5) but decreased with wind speed $(z=-5.00, p<0.001$, Fig. 2$)$ and Julian day $(z=-5.29, p<0.001$, Fig. 3). The odds of detecting Cope's gray treefrogs was estimated to be $3.6(95 \%$ C.I. $=1.8,7.5)$ and $3.0(95 \%$ C.I. $=$ 1.7, 5.3) times greater with every standardized unit increase in air temperature and cloud cover, respectively. The odds of detecting Cope's gray treefrogs was estimated to be 0.8 ( $95 \%$ C.I. $=$ $0.6,0.9)$ and $0.9(95 \%$ C.I. $=0.7,0.9)$ times less for every standardized unit increase in wind speed and Julian day, respectively. A likelihood ratio test did not support the inclusion of survey method in the final model $\left(X^{2}{ }_{2}=0.11, P=0.95\right)$. A likelihood ratio test confirmed the explanatory capability of terms in the final model $\left(X^{2}{ }_{8}=68.03, P<0.001\right)$.

\section{Gray Treefrog (Hyla versicolor)}

The best model describing occupancy of gray treefrogs contained air temperature, wind speed, and Julian day. Wetland type and year did not affect occupancy (Table 2). Detection probability of gray treefrogs increased with air temperature $(z=4.38, p<0.001$, Fig. 4$)$ but decreased with wind speed $(z=-3.33, p<0.001$, Fig. 2$)$ and Julian day $(z=-5.32, p<0.001$, Fig. 3). The odds of detecting gray treefrogs was estimated to be $14.4(95 \%$ C.I. $=4.4,47.6)$ times greater with every standardized unit increase in air temperature. The odds of detecting gray treefrogs was estimated to be $0.9(95 \%$ C.I. $=0.7,1.0)$ and $1.0(95 \%$ C.I. $=0.9,1.0)$ times less for every standardized unit increase in wind speed and Julian day, respectively. A likelihood ratio test did 
not support the inclusion of survey method in the final model $\left(X^{2}{ }_{2}=0.20, P=0.90\right)$. A likelihood ratio test confirmed the explanatory capability of terms in the final model $\left(X^{2}{ }_{7}=64.38, P<\right.$ $0.001)$.

American Bullfrog (Lithobates catesbeianus) and Pickerel Frog (Lithobates palustris)

The best model describing occupancy of both American bullfrogs and pickerel frogs was the null model which described both occupancy and detection probability as constant. Occupancy was thus constant across wetland types and years (Table 2). The detection probabilities of these species were not affected by any of our measured variables.

\section{Green Frog (Lithobates clamitans)}

The best model describing occupancy of green frogs contained water temperature, wind speed, and Julian day. Wetland type and year did not affect occupancy (Table 2). Detection probability of green frogs increased with water temperature $(z=3.67, p<0.001$, Fig. 6$)$, wind speed $(z=$ 2.60, $p=0.009$, Fig. 2), and Julian day $(z=4.80, p<0.001$, Fig. 3). The odds of detecting green frogs was estimated to be $1.6(95 \%$ C.I. $=1.3,2.1), 1.4(95 \%$ C.I. $=1.1,1.7)$, and $2.1(95 \%$ C.I. $=$ 1.6, 2.8) times greater with every standardized unit increase in water temperature, wind speed, and Julian day, respectively. A likelihood ratio test supported the inclusion of survey method in the final model $\left(X^{2}{ }_{2}=7.79, P=0.02\right)$; the odds of detection using a broadcast survey were 2.06 times better $(95 \%$ C.I. $=1.20,3.53)$ than 5 -minute surveys. The odds of detection using a tenminute survey were 1.69 times better $(95 \%$ C.I. $=1.00,2.84)$ than five-minute surveys. The odds of detection using a broadcast survey were 1.22 times better than ten-minute surveys; this 
difference was not significant $(95 \%$ C.I. $=0.70,2.14)$. A likelihood ratio test confirmed the explanatory capability of terms in the final model $\left(X^{2}{ }_{7}=101.29, P<0.001\right)$.

\section{Wood Frog (Lithobates sylvaticus)}

The best model describing occupancy of wood frogs contained wind speed and Julian day. Effects on occupancy were similar across wetland types but significantly different between 2009 and 2010 (Table 2). Detection probability of wood frogs increased with both wind speed $(z=$ 2.54, $p=0.001$, Fig. 2$)$ and Julian day $(z=4.39, p<0.001$, Fig. 3). The odds of detecting wood frogs was estimated to be $1.5(95 \%$ C.I. $=1.1,2.1)$ and $2.1(95 \%$ C.I. $=1.5,3.0)$ times greater with every standardized unit increase in wind speed and Julian day, respectively. A likelihood ratio test did not support the inclusion of survey method in the final model $\left(X^{2}{ }_{2}=0.13, P=0.94\right)$. A likelihood ratio test confirmed the explanatory capability of terms in the final model $\left(X^{2}{ }_{6}=\right.$ 46.36, $P<0.001)$.

\section{Spring Peeper (Pseudacris crucifer)}

The best model describing occupancy of spring peepers contained air temperature, cloud cover, wind speed, and Julian day. Wetland type and year did not affect occupancy (Table 2). Detection probability of spring peepers increased with air temperature $(z=2.04, p=0.004$, Fig. 4$)$ and cloud cover $(z=3.96, p<0.001$, Fig. 5), but decreased with wind speed $(z=-2.38, p=0.018$, Fig. 2) and Julian day $(z=-8.34, p<0.001$, Fig. 3). The odds of detecting spring peepers was estimated to be $1.5(95 \%$ C.I. $=1.0,2.2)$ and $1.7(95 \%$ C.I. $=1.3,2.3)$ times greater with every standardized unit increase in air temperature and cloud cover, respectively. The odds of detecting spring peepers was estimated to be $0.3(95 \%$ C.I. $=0.1,0.5)$ and $0.9(95 \%$ C.I. $=0.8,0.9)$ times 
less for every standardized unit increase in wind speed and Julian day, respectively. A likelihood ratio test did not support the inclusion of survey method in the final model $\left(X^{2}{ }_{2}=0.003, P=\right.$ 1.00). A likelihood ratio test confirmed the explanatory capability of terms in the final model $\left(X_{8}^{2}=168.05, P<0.001\right)$.

\section{Species Richness}

The best model describing the species richness of calling anurans was fit using a Poisson distribution on $N$, and contained relative humidity and Julian day. Wetland type $(z=-1.67, p=$ $0.09)$ and year $(z=-0.48, p=0.63)$ were not significantly different (Table 3$)$; mean anuran species richness was similar between created and natural wetlands and between the 2009 and 2010 sampling seasons. Relative humidity and Julian day significantly affected detection of calling anurans, but in different directions: detection probability increased with relative humidity and decreased over time. In terms of odds ratios (derived by exponentiating the logit scale estimates), the odds of detecting calling anurans was estimated to be $1.2(95 \%$ C.I. $=1.0,1.4)$ times greater with every standardized unit increase in relative humidity. The odds of detecting calling anurans was estimated to be $0.5(95 \%$ C.I. $=0.4,0.6)$ times less for every standardized unit increase in Julian day. We calculated a detection probability estimate using a logistic transformation in conjunction with the Delta Method. The estimate of detection probability, at mean relative humidity and Julian day, was $0.53(95 \%$ C.I. $=0.45,0.60)$. We compared the best model against the null model with a likelihood ratio test to confirm the explanatory capability of the terms contained in the model; relative humidity and Julian day had significant explanatory capability $\left(X^{2}{ }_{4}=60.36, P<0.001\right)$. 


\section{Discussion}

We used occupancy estimation to demonstrate that the created and natural wetlands that we monitored did not differ with respect to occupancy (e.g., the proportion of sites occupied) of anurans. This provides evidence that amphibians are colonizing and using created wetlands as breeding habitat throughout the Central Appalachian region. Our results support similar findings that created wetlands in the Appalachian region are overall functionally similar to natural wetlands (Balcombe et al. 2005a, 2005b, 2005c, 2005d). Examining some of the same wetlands used in the present study, Balcombe et al. (2005a) determined that species richness, Wisconsin index values, and abundance of calling anurans were similar or higher in created wetlands compared to reference wetlands. We reached similar conclusions, but did so within a modeling framework that explicitly accounted for imperfect detection, thus providing stronger inference about the occupancy status of anurans in created wetlands.

Amphibians colonize restored wetlands rapidly (within several months, Lehtinen and Galatowitsch 2001), and may reach a similar species composition as natural wetlands in under three years (Petranka et al. 2003b). Although amphibians colonize created or restored wetlands rapidly, these wetlands need to provide the appropriate habitat conditions to maintain amphibian populations. The created and natural wetlands in our study had similar anuran assemblages, but Pechmann et al. (2001) cautioned that some created wetlands may provide only partial mitigation because of amphibian community structure differences. For instance, because created wetlands tend to exhibit more permanent hydroperiods than natural wetlands (Cole and Brooks 2000, Balcombe et al. 2005d), species adapted to ephemeral wetland conditions may be absent from many created wetlands (Brown et al. 2012). 
The design and construction of created wetlands is essential from a habitat suitability perspective, as the richness and abundance of amphibians depends on factors such as bank slope, wetland size, depth, fish abundance, hydroperiod, and vegetative cover (Lesbarreres et al. 2010, Shulse et al. 2010). Landscape parameters, such as proximity to other aquatic habitat, nearby forest, road density, and urbanization also affect the suitability of created and restored wetlands as amphibian habitat (Stevens et al. 2002, Shulse et al. 2010, Guzy et al. 2012). Guzy et al. (2012) found that anuran occupancy was strongly correlated with several plant and physicochemical metrics, and concluded that anurans may be effective indicators of the biotic integrity of wetlands. We did not examine factors affecting the occupancy of anurans in wetlands, and this would be a useful avenue of research to identify determinants of occupancy by amphibians in the Central Appalachian region.

Occupancy estimates for species in our study were similar to recent studies that have used detection/nondetection data to estimate detection probabilities and occupancy. Notably, our estimates were similarly high for American toads ( $\Psi=\sim 0.6-0.7$ in West Virginia, Weir et al. 2009 ) and spring peepers ( $\Psi=\sim 0.90-0.95$ in West Virginia, Weir et al. $2009 ; \Psi=0.95$ in Massachusetts, Cook et al. 2011), which demonstrates the ubiquity of these species throughout the Northeast. Interestingly, our occupancy estimate for green frogs was 1.0 (green frogs occupied every wetland) and similar to Cook et al.'s (2011) estimate of 0.79, whereas Weir et al. (2009) obtained much lower estimates of occupancy in West Virginia ( $\Psi=\sim 0.1-0.3)$. The difference may be methodological: Cook et al. (2011) and our study included wetlands that were not necessarily close to roads, as they must be under the North American Amphibian Monitoring Program protocol, data from which was used by Weir et al. (2009). Green frogs, which call at a relatively low frequency (Cunnington and Fahrig 2010), may be more difficult to detect in the 
presence of road noise than species that call at a higher frequency such as spring peepers and gray treefrogs (Cunnington and Fahrig 2010).

With the exception of the wood frog, there was no change in occupancy from 2009 to 2010, compared to studies that found year-to-year changes (Weir et al. 2009, Cook et al. 2011). Occupancy of vernal pools by breeding adult wood frogs (as measured by presence of egg masses) was correlated with spring precipitation (Green et al. 2013). A longer 2010 winter delayed the onset of spring in our study area, which may have extended the normally short breeding period for wood frogs. This delay may have enabled us to detect wood frogs at more sites, increasing the occupancy estimate. It is likely that given additional years of sampling, we would observe changes in occupancy in more species, as anurans undergo frequent site turnover (Trenham et al. 2003).

Our naïve (i.e., unadjusted) estimates of occupancy (Table 2) demonstrate the importance of incorporating detection probabilities when modeling wildlife dynamics. For instance, the model estimates for American toads in created wetlands were 0.76 and 0.83 in 2009 and 2010, respectively; occupancy based on the observed data was much lower at 0.33 in 2009 and 0.29 in 2010. Weir et al. (2005) also found that occupancy estimates unadjusted for detection probability consistently underestimated the occupancy of breeding anurans. Because the detection probability of anurans varies depending on several factors, failure to account for false absences is likely to result in biased inferences (MacKenzie and Bailey 2004).

Several environmental covariates had a significant effect on the detectability of calling anurans in our study. Detection probability increased with Julian day for green and wood frogs but decreased for American toads, Cope's gray treefrogs, gray treefrogs, and spring peepers. Weir et al. (2005) also found that Julian day affected the detection of these species and in the 
same way for most species. One notable difference is that the detection of both gray treefrog species in our study decreased substantially with Julian day, whereas it was consistently low throughout their study. Another difference was detection of green frogs: our estimates of detection with Julian day increased from 0.62 to 0.94 (based on ten-minute call surveys), whereas Weir et al. (2005) estimated a maximum detection probability across the season of 0.06. This discrepancy in green frog detection probabilities further supports our previous argument that an increase in road noise decreases the ability of observers to detect green frogs, and warrants further investigation.

Ambient temperature influences the detection probability of multiple anuran species (Weir et al. 2005, Cook et al. 2011). Cook et al. (2011) found that the detection of green frogs and spring peepers was positively influenced by both air and water temperature. We found that the detection of green frogs was affected by water temperature, and the detection of spring peepers was affected by air temperature. This is reasonable, considering that green frogs vocalize from partially submerged perches (Pauley and Lannoo 2005), whereas spring peepers primarily climb onto wetland vegetation to call (Butterfield et al. 2005). Weir et al. (2005) found that above $24^{\circ} \mathrm{C}$, detection of gray treefrogs decreased and detection of Cope's gray treefrogs increased. The authors suggested that observer error may be partly responsible for this pattern. We found that the detection of both species increased with air temperature; although on only one occasion during our study did air temperature exceed $24^{\circ} \mathrm{C}$.

Weir et al. (2005) found that of 5 species affected by wind speed, the detection of 4 decreased with increasing speed whereas the detection of one species (upland chorus frog, Psuedacris feriarum) increased with wind speed. The authors suggested that the increase in detection probability with wind speed may be a spurious effect of their stepwise model selection 
procedure. We found that detection probability of Cope's gray treefrogs, gray treefrogs, and spring peepers decreased with wind speed but the detection of American toads, green frogs and wood frogs increased with wind speed. We hypothesize that the increase in detection with wind speed for these three species may be due to the decrease in calling activity for other (typically louder) species, thus increasing the ability of observers to detect American toads, green frogs and wood frogs. It is important to note that, although not included in the final model for any single species, relative humidity affected the detection of calling anurans as a whole (as shown in the species richness analysis). Relative humidity has been shown to significantly affect the detection of anurans (Oseen and Wassersug 2002), although not always positively (Steelman and Dorcas 2010).

We found that the detection of calling anurans was largely similar between five-minute, ten-minute, and broadcast call surveys, which suggests that five-minute surveys are adequate for the detection of amphibian assemblages in Central Appalachian wetlands. Shirose et al. (1997) found that the majority of anuran species in Ontario wetlands were detected within the first minute of their call surveys. Although new species were occasionally detected 15 minutes after the start of surveys, the authors concluded that three-minute surveys were ideal as detection of new species declined significantly after 3 minutes. In contrast, other studies have found that longer surveys are required for reliable detection of all species at a site (Crouch and Paton 2002, Pierce and Gutzwiller 2004). Crouch and Paton (2002) detected $81 \%$ of anuran species within the first two minutes in Rhode Island wetlands, but they calculated that ten-minute surveys were required to have a high probability of detecting all species at a site. Although the detection of some anurans inhabiting central Texas wetlands was not influenced by survey duration, a 15- 
minute survey was required to achieve a 94\% detection efficiency of all species (Pierce and Gutzwiller 2004).

Mannan (2008) found that in the tundra of Manitoba, broadcasting advertisement calls increased the number of wood frogs detected during a survey, although broadcasts did not increase the number of boreal chorus frogs (Pseudacris maculata) compared to manual call surveys. We found an increase in detection with broadcast calls for only one species (green frogs) compared to manual call surveys and therefore suggest that broadcasting species' calls is not worth the added effort and equipment.

An additional technique that we did not test but that has been used frequently is automated recording systems (ARS), or "frogloggers" (Dorcas et al. 2009). ARS has the benefit of being able to record anuran advertisements throughout the day and night at regular intervals as opposed to the "snapshot" of calling activity that manual call surveys provide. This would enable detection of species that may primarily call outside of the evening hours typical of manual call survey protocols (Bridges and Dorcas 2000). However, ARS is very expensive and has issues, such as vandalism and theft of recording equipment (Corn et al. 2000, Dorcas et al. 2009). Corn et al. (2000) found that the species richness of calling anurans was similar between ARS and 3minute manual call survey, which provides evidence that the most cost-effective technique to survey breeding anurans in created wetlands is the manual call survey, provided that observers are properly trained (Genet and Sargent 2003). We suggest that a 5-minute manual call survey is appropriate, but clearly more work is needed to determine the optimal survey duration.

Observer variability is likely to be a factor that influences detection of calling anurans, and many other studies have incorporated observer identity or experience as a covariate, especially when volunteers are used (e.g., Weir et al. 2005, Lotz and Allen 2007, McClintock et 
al. 2010). In our study, $90 \%$ of the 279 surveys were conducted by the lead author (GFS); two trained wildlife student observers conducted the remaining surveys. These students also accompanied GFS to several sites before performing their own surveys to ensure agreement between species identification and call index values. As a result of this procedure, we believe that observer variability was minimized to the extent possible and therefore did not include observer identity in our models.

Occupancy was affected by proportion of forested wetland in Maryland for seven species (Weir et al. 2005), which included species encountered during the present study. In an effort to keep models simple, we did not include landuse or landscape parameters in our models. Examining parameters such as distance to nearest road (Kirlin et al. 2006) may be especially useful in a wetland mitigation context because wetlands are often created adjacent to or near anthropogenically disturbed areas (National Research Council 2001). Future inclusion of landscape variables such as the proportion of forested wetland into models of amphibian occupancy may demonstrate the consequences of consistently replacing lost forested wetland with other wetland types (Cole and Shafer 2002, Robb 2002, Todd et al. 2009).

Occupancy is a useful surrogate for abundance because the data are relatively easy to collect and can be used to detect trends in species that are distributed patchily throughout a region, such as breeding anurans (MacKenzie and Nichols 2004). Extensions of occupancy models have been developed to enable estimation of colonization and extinction rates (MacKenzie and Nichols 2004). The data provided via call surveys (detection/nondetection of species at sites) can easily be applied to monitor long-term trends in anuran populations (Corn et al. 2000). 
Data used in this study were obtained from relatively generalist amphibians such as American toads (Green 2005), spring peepers (Butterfield et al. 2005), and green frogs (Pauley and Lannoo 2005). It is important to consider that similarity between created and natural wetlands may not hold for species with more specific breeding habitat requirements such as fourtoed salamanders and spotted salamanders (Petranka 1998). More work is required to determine how well created wetlands support populations of specialist amphibians.

Although we determined that adult anurans are readily using created wetlands for breeding, these results alone do not indicate that anurans are reproducing successfully. Anurans may call and breed at created wetlands, but mortality of eggs or larvae may result in reproductive failure (Petranka et al. 2003b, Vasconcelos and Calhoun 2006). However, we determined, via estimation of amphibian metamorph abundance, that spring peeper and green frog reproduction was similar to that in natural wetlands at a subset of the wetlands used in the present study during the same time period (Strain et al. In review). This provides evidence that the created wetlands used in this study serve as reproductive habitat for amphibians throughout the Central Appalachian region.

\section{Acknowledgments}

We thank E. Miller, B. Olejasz, A. Nemeyer, and N. McCoard for help in the field. Funding and logistical support was provided by the WVU Division of Forestry and Natural Resources through the McIntire-Stennis program, the WVU Environmental Research Center, the National Oceanic and Atmospheric Administration, and a student research grant to GFS from the South Atlantic Chapter of the Society of Wetland Scientists. This is scientific article number XXXX of the WVU Agriculture and Forestry Experiment Station. 


\section{Literature Cited}

Alford, R.A., and S.J. Richards. 1999. Global amphibian declines: a problem in applied ecology. Annual Review of Ecology and Systematics 30:133-65.

Balcombe, C.K., J.T. Anderson, R.H. Fortney, and W.S. Kordek. 2005a. Wildlife use of mitigation and reference wetlands in West Virginia. Ecological Engineering 25:85-99.

Balcombe, C.K., J.T. Anderson, R.H. Fortney, J.S. Rentch, W.N. Grafton, and W.S. Kordek. 2005b. A comparison of plant communities in mitigation and reference wetlands in the mid-Appalachians. Wetlands 25:130-142.

Balcombe, C.K., J.T. Anderson, R.H. Fortney, and W.S. Kordek. 2005c. Vegetation, invertebrate, and wildlife community rankings and habitat analysis of mitigation wetlands in West Virginia. Wetlands Ecology and Management 13:517-530.

Balcombe, C.K., J.T. Anderson, R.H. Fortney, and W.S. Kordek. 2005d. Aquatic macroinvertebrate assemblages in mitigated and natural wetlands. Hydrobiologia $541: 175-188$.

Bridges, A.S., and M.E. Dorcas. 2000. Temporal variation in anuran calling behavior: implications for surveys and monitoring programs. Copeia 2000:587-592.

Brinson, M.M., and A.I. Malvarez. 2002. Temperate freshwater wetlands: types, status, and threats. Environmental Conservation 29:115-133.

Brown, D.J., G.M. Street, R.W. Nairn, and M.R.J. Forstner. 2012. A place to call home: amphibian use of created and restored wetlands. International Journal of Ecology 2012:111.

Burnham, K.P., and D.R. Anderson. 2002. Model selection and multi-model inference. 2nd ed. Springer, Berlin, Germany. 
Butterfield, B.P., M. Lannoo, and P. Nanjappa. 2005. Pseudacris crucifer. Pages 889-894 in Lannoo, M. (Ed.). Amphibian declines. University of California Press, Berkeley.

Campbell, D.A., C.A. Cole, and R.P. Brooks. 2002. A comparison of created and natural wetlands in Pennsylvania, USA. Wetlands Ecology and Management 10:41-49.

Cole, C.A., and R.P. Brooks. 2000. A comparison of the hydrologic characteristics of natural and created mainstem floodplain wetlands in Pennsylvania. Ecological Engineering 14:221-231.

Cole, C.A., and D. Shafer. 2002. Section 404 wetland mitigation and permit success criteria in Pennsylvania, USA, 1986-1999. Environmental Management 30:508-515.

Cook, R.P., T.A. Tupper, P.W.C. Paton, and B.C. Timm. 2011. Effects of temperature and temporal factors on anuran detection probabilities at Cape Cod National Seashore, Massachusetts, USA: implications for long-term monitoring. Herpetological Conservation and Biology 6:25-39.

Corn, P.S., E. Muths, and W.M. Iko. 2000. A comparison in Colorado of three methods to monitor breeding amphibians. Northwestern Naturalist 81:22-30.

Cowardin, L.M., V. Carter, F.C. Golet, and E.D. LaRoe. 1979. Classification of wetlands and deepwater habitats of the United States. Publication FWS/OBS-79/31. U.S. Department of Interior, Fish and Wildlife Service, Office of Biological Services, Washington, D.C.

Crouch, W.B., III, and P.W.C. Paton. 2002. Assessing the use of call surveys to monitor breeding anurans in Rhode Island. Journal of Herpetology 36:185-192.

Cunnington, G.M., and L. Fahrig. 2010. Plasticity in the vocalizations of anurans in response to traffic noise. Acta Oecologica 36:463-470.

Dahl, T.E. 1990. Wetlands losses in the United States 1780 's to 1980 's. U.S. Department 
of the Interior, Fish and Wildlife Service, Washington, D.C., USA.

Dahl, T.E. 2006. Status and trends of wetlands in the conterminous United States 1998 to 2004. U.S. Department of the Interior, Fish and Wildlife Service, Washington, D.C., USA.

Dahl, T.E. 2011. Status and trends of wetlands in the conterminous United States 2004 to 2009. U.S. Department of the Interior, Fish and Wildlife Service, Washington, D.C., USA.

Dahl, T.E., and C.E. Johnson. 1991. Status and trends of wetlands in the conterminous United States, mid-1970’s to mid-1980’s. U.S. Department of the Interior, Fish and Wildlife Service, Washington, D.C., USA.

Dixon, P.M. 2002. Bootstrap resampling. Pages 212-220 in A.H. El-Shaarawi and W.W. Piegorsch (Eds.). Encyclopedia of environmetrics. John Wiley and Sons, Chichester.

Dorcas, M.E., S.J. Price, S.C. Walls, and W.J. Barichivich. 2009. Auditory monitoring of anuran populations. Pages 281-298 in K. Dodd (Ed.). Conservation and ecology in amphibians. Oxford University Press, Oxford, UK.

Environmental Protection Agency [EPA]. 2012. Wetlands and people. < http://water.epa.gov/type/wetlands/people.cfm>. Accessed 10 Jul 2013.

Fiske, I.J., and R.B. Chandler. 2011. Unmarked: an R package for fitting hierarchical models of wildlife occurrence and abundance. Journal of Statistical Software 43:1-23.

Gallant, A.L., R.W. Klaver, G.S. Casper, and M.J. Lannoo. 2007. Global rates of habitat loss and implications for amphibian conservation. Copeia 2007: 967-979.

Genet, K.S., and L.G. Sargent. 2003. Evaluation of methods and data quality from a volunteer-based amphibian call survey. Wildlife Society Bulletin 31:703-714.

Gibbons, J.W. 2003. Terrestrial habitat: a vital component for herpetofauna of isolated 
wetlands. Wetlands 23:630-635.

Gingerich, R.T., and J.T. Anderson. 2011. Decomposition trends of five plant litter types in mitigated and reference wetlands in West Virginia, USA. Wetlands 31:653-662.

Green, D.M. 2005. Bufo americanus. Pages 386-390 in Lannoo, M. (ed). Amphibian declines. University of California Press, Berkeley, MD.

Green, A.W., M.B. Hooten, E.H.C. Grant, and L.L. Bailey. 2013. Evaluating breeding and metamorph occupancy and vernal pool management effects for wood frogs using a hierarchical model. Journal of Applied Ecology 50:1116-1123.

Guzy, J.C., E.D. McCoy, A.C. Deyle, S.M. Gonzalez, N. Halstead, and H.R. Mushinsky. 2012. Urbanization interferes with the use of amphibians as indicators of ecological integrity of wetlands. Journal of Applied Ecology 49:941-952.

Hossler, K., V. Bouchard, M.S. Fennessy, S.D. Frey, E. Anemaet, and E. Herbert. 2011. No-netloss not met for nutrient function in freshwater marshes: recommendations for wetland mitigation policies. Ecosphere 2:1-36.

Jelinski, N.A., C.J. Kucharik, and J.B. Zedler. 2011. A test of diversity-productivity models in natural, degraded, and restored wet prairies. Restoration Ecology 19:186-193.

Kery, M., R.M. Dorazio, L. Soldaat, A. van Strien, A. Zuiderwijk, and J.A. Royle. 2009. Trend estimation in populations with imperfect detection. Journal of Applied Ecology 46:11631172.

Kirlin, M.S., M.M. Gooch, S.J. Price, and M.E. Dorcas. 2006. Predictors of winter anuran calling activity in the North Carolina Piedmont. Journal of the North Carolina Academy of Science 122:10-18.

Lehtinen, R.M., and S.M. Galatowitsch. 2001. Colonization of restored wetlands by amphibians 
in Minnesota. American Midland Naturalist 145:388-396.

Lesbarrerees, D., M.S. Fowler, A. Pagano, and T. Lode. 2010. Recovery of anuran community diversity following habitat replacement. Journal of Applied Ecology 47:148-156.

Lotz, A., and C.R. Allen. 2007. Observer bias in anuran call surveys. Journal of Wildlife Management 71:675-679.

MacKenzie, D.I., and L.L. Bailey. 2004. Assessing the fit of site-occupancy models. Journal of Agricultural, Biological, and Environmental Statistics 9:300-318.

MacKenzie, D.I., and W.L. Kendall. 2002. How should detection probability be incorporated into estimates of relative abundance? Ecology 83:2387-2393.

MacKenzie, D.I., and J.D. Nichols. 2004. Occupancy as a surrogate for abundance estimation. Animal Biodiversity and Conservation 24:461-467.

MacKenzie, D.I., J.D. Nichols, G.B. Lachman, S. Droege, J.A. Royle, and C.A. Langtimm. 2002. Estimating site occupancy rates when detection probabilities are less than one. Ecology 83:2248-2255.

MacKenzie, D.I., J.D. Nichols, J.A. Royle, K.H. Pollock, L.L. Bailey, and J.E. Hines. 2006. Occupancy estimation and modeling: inferring patterns and dynamics of species occurrence. Academic Press, Burlington, MA, USA.

Mannan, R.N. 2008. An assessment of survey methodology, calling activity, and habitat associations of wood frogs (Rana sylvatica) and boreal chorus frogs (Pseudacris maculata) in a tundra biome. Thesis, Texas Tech University, Lubbock, TX, USA.

Marsh, D.M., and P.C. Trenham. 2001. Metapopulation dynamics and amphibian conservation. Conservation Biology 15:40-49.

McClintock, B.T., L.L. Bailey, K.H. Pollock, and T.R. Simons. 2010. Experimental investigation 
of observation error in anuran call surveys. Journal of Wildlife Management 74:18821893.

Mitsch, W.J., and J.G. Gosselink. 2007. Wetlands. $4^{\text {th }}$ ed. Wiley and Sons, Hoboken, New Jersey, USA.

NAAMP. 2005. USGS North American Amphibian Monitoring Program (NAAMP). USGS Patuxent Wildlife Research Center, Laurel, MD, USA. <http://www.pwrc.usgs. gov/naamp>. Accessed 23 February 2008.

Naiman, R.J., C.A. Johnston, and J.C. Kelley. 1988. Alteration of North American streams by beaver. BioScience 38:753-762.

National Research Council. 2001. Compensating for wetland losses under the Clean Water Act. National Academy Press, Washington D.C., USA.

Nichols, J.D. 1992. Capture-recapture models: using marked animals to study population dynamics. BioScience 42:92-102.

Oseen, K.L., and R.J. Wassersug. 2002. Environmental factors influencing calling in sympatric anurans. Oecologia 133:616-625.

Pauley, T.K. 2000. Amphibians and reptiles in wetland habitats of West Virginia. Proceedings of the West Virginia Academy of Sciences 72:78-88.

Pauley, T.K., and M. Lannoo. 2005. Rana clamitans. Pages 889-894 in Lannoo, M. (ed) Amphibian declines. University of California Press, Berkeley, CA, USA.

Pechmann, J.H.K., R.A. Estes, D.E. Scott, and J.W. Gibbons. 2001. Amphibian colonization and use of ponds created for trial mitigation of wetland loss. Wetlands 21:93-111.

Pellet, J., and B.R. Schmidt. 2005. Monitoring distributions using call surveys: estimating site 
occupancy, detection probabilities and inferring absence. Biological Conservation 123:27-35.

Petranka, J.W. 1998. Salamanders of the United States and Canada. Smithsonian Institution Press, Washington, D.C., USA.

Petranka, J.W., C.A. Kennedy, and S.S. Murray. 2003a. Response of amphibians to restoration of a southern Appalachian wetland: a long-term analysis of community dynamics. Wetlands 23:1030-1042.

Petranka, J.W., S.S. Murray, and C.A. Kennedy. 2003b. Responses of amphibians to restoration of a southern Appalachian wetland: perturbations confound post-restoration assessment. Wetlands 23:278-290.

Phillips, K. 1990. Where have all the frogs and toads gone? BioScience 40:422-424.

Pierce, B.A., and K.J. Gutzwiller. 2004. Auditory sampling of frogs: detection efficiency in relation to survey duration. Journal of Herpetology 38:495-500.

Pope, S.E., L. Fahrig, and H.G. Merriam. 2000. Landscape complementation and metapopulation effects on leopard frog populations. Ecology 81:2498-2508.

Robb, J.T. 2002. Assessing wetland compensatory mitigation sites to aid in establishing mitigation ratios. Wetlands 22:435-440.

Royle, J.A. 2004. N-mixture models for estimating population size from spatially replicated counts. Biometrics 60:108-115.

Semlitsch, R.D., and J.R. Bodie. 1998. Are small, isolated wetlands expendable? Conservation Biology 12:1129-1133.

Shirose, L.J., C.A. Bishop, D.M. Green, C.J. MacDonald, R.J. Brooks, and N.J. Helferty. 1997. 
Validation tests of an amphibian call count survey technique in Ontario, Canada. Herpetologica 53:312-320.

Shulse, C.D., R.D. Semlitsch, K.M. Trauth, and A.D. Williams. 2010. Influences of design and landscape placement parameters on amphibian abundance in constructed wetlands. Wetlands 30:915-928.

Steelman, C.K., and M.E. Dorcas. 2010. Anuran calling survey optimization: developing and testing predictive models of anuran calling activity. Journal of Herpetology 44:61-68.

Stevens, C.E., A.W. Diamond, and T.S. Gabor. 2002. Anuran call surveys on small wetlands in Prince Edward Island, Canada restored by dredging of sediments. Wetlands 22:90-99.

Strain, G.F., P.J. Turk, J. Helmick, and J.T. Anderson. In review. Amphibian reproductive success as a gauge of functional equivalency of created wetlands in the Central Appalachians. Journal of Fish and Wildlife Management.

Todd, B.D, T.M. Luhring, B.B. Rothermel, and J.W. Gibbons. 2009. Effects of forest removal on amphibian migrations: implications for habitat and landscape connectivity. Journal of Applied Ecology 46:554-561.

Trenham, P.C., W.D. Koenig, M.J. Mossman, S.L. Stark, and L.A. Jagger. 2003. Regional dynamics of wetland-breeding frogs and toads: turnover and synchrony. Ecological Applications 13:1522-1532.

Turner, R.E., A.M. Redmond, and J.B. Zedler. 2001. Count it up by acre or function mitigation adds up to net loss of wetlands. National Wetlands Newsletter 23:5-16.

Vasconcelos, D., and A.J.K. Calhoun. 2006. Monitoring created seasonal pools for functional success: a six-year study of amphibian responses, Sears Island, Maine, USA. Wetlands 26:992-1003. 
Weir, L., I.J. Fiske, and J.A. Royle. 2009. Trends in anuran occupancy from northeastern states of the North American Amphibian Monitoring Program. Herpetological Conservation and Biology 4:389-402.

Weir, L., J.A. Royle, P. Nanjappa, and R.E. Jung. 2005. Modeling anuran detection and site occupancy on North American Amphibian Monitoring Program (NAAMP) routes in Maryland. Journal of Herpetology 39:627-639.

Whigham, D.F. 1999. Ecological issues related to wetland preservation, restoration, creation and assessment. The Science of the Total Environment 240:31-40.

Yoccoz, N.G., J.D. Nichols, and T. Boulinier. 2001. Monitoring of biological diversity in space and time. Trends in Ecology and Evolution 16:446-453.

Zedler, J.B. 1996. Ecological issues in wetland mitigation: an introduction to the forum. Ecological Applications 6:33-37.

Zimmerman, B.L. 1994. Audio strip transects. Pages 92-97 in W.R. Heyer, M.A. Donnelly, R.W. McDiarmid, L.C. Hayek, and M.S. Foster (Eds.). Measuring and monitoring biological diversity. Standard methods for amphibians. Smithsonian Institution. Washington, D.C., USA. 
Table 1. Attributes of natural $(n=12)$ and created $(n=12)$ wetlands used to study call phenology of anurans in the Central Appalachians (Size refers to the area of the inundated basin of each wetland). Cowardin classifications based on Cowardin et al. (1979).

\begin{tabular}{|c|c|c|c|c|c|c|}
\hline Wetland & Type & Size (ha) & County & Elevation $(\mathrm{m})$ & Geology & Cowardin Classification \\
\hline Buffalo Coal 2 & Created & 2.8 & Grant, WV & 1018 & Shale & Palustrine \\
\hline Edward's Run WMA & Created & 2.2 & Hampshire, WV & 250 & Sandstone & Palustrine scrub-shrub \\
\hline Elk Run & Created & 3.8 & Grant, WV & 840 & Shale & Palustrine unconsolidated bottom organic \\
\hline Enoch Branch & Created & 1.7 & Nicholas, WV & 570 & Sandstone & Palustrine emergent persistent \\
\hline Everhart Seep & Created & 0.27 & Garrett, MD & 812 & Sandstone & Palustrine emergent persistent \\
\hline Hazelton & Created & 8.5 & Preston, WV & 560 & Sandstone & Palustrine emergent persistent \\
\hline Leading Creek & Created & 8.6 & Randolph, WV & 600 & Alluvium & Palustrine emergent persistent \\
\hline Stauffer's Marsh & Created & 3.5 & Berkeley, WV & 145 & Alluvium & Palustrine emergent persistent \\
\hline Sugar Creek & Created & 6.8 & Barbour, WV & 478 & Sandstone & Palustrine emergent persistent \\
\hline Upper Deckers Creek WMA & Created & 2.4 & Preston, WV & 518 & Shale & Palustrine aquatic bed floating vascular \\
\hline VEPCO & Created & 7 & Tucker, WV & 1036 & Sandstone & Palustrine moss-lichen \\
\hline Walnut Bottom & Created & 10 & Hardy, WV & 335 & Shale & Palustrine emergent persistent \\
\hline Camp 70 & Natural & 0.02 & Tucker, WV & 952 & Shale & Palustrine unconsolidated shore vegetated \\
\hline Garrett State Forest North & Natural & 2 & Garrett, MD & 760 & Sandstone & Palustrine unconsolidated shore vegetated \\
\hline Garrett State Forest South & Natural & 2 & Garrett, MD & 737 & Sandstone & Palustrine unconsolidated shore vegetated \\
\hline Glade Run & Natural & 2 & Tucker, WV & 962 & Limestone & Palustrine emergent persistent \\
\hline Joe Mood & Natural & 1 & Preston, WV & 515 & Sandstone & Palustrine unconsolidated shore vegetated \\
\hline Kempton Swamp & Natural & 3.5 & Garrett, MD & 820 & Shale & Palustrine emergent persistent \\
\hline Muddlety & Natural & 7 & Nicholas, WV & 566 & Sandstone & Palustrine emergent persistent \\
\hline Old Fields & Natural & 4 & Hardy, WV & 292 & Shale & Palustrine emergent persistent \\
\hline Rail Trail South & Natural & 4.1 & Preston, WV & 525 & Shale & Palustrine forested broad-leaved deciduous \\
\hline Rail Trail North & Natural & 4.7 & Preston, WV & 515 & Shale & Palustrine forested broad-leaved deciduous \\
\hline Short Mountain WMA & Natural & 3.8 & Hampshire, WV & 625 & Sandstone & Palustrine emergent persistent \\
\hline Upper Deckers & Natural & 2.6 & Preston, WV & 512 & Sandstone & Palustrine aquatic bed floating vascular \\
\hline
\end{tabular}


Table 2. Naïve and model-based probability estimates (+/- $1 \mathrm{SE})$ for wetland occupancy $(\Psi)$ in models describing the occupancy by calling adult anurans encountered in created and natural wetlands of the Central Appalachians during 2009 and 2010 ("N/A" indicates that wetland type and year were not in the final model for Lithobates catesbeianus or L. palustris; naïve estimates based on data from 5-minute call surveys).

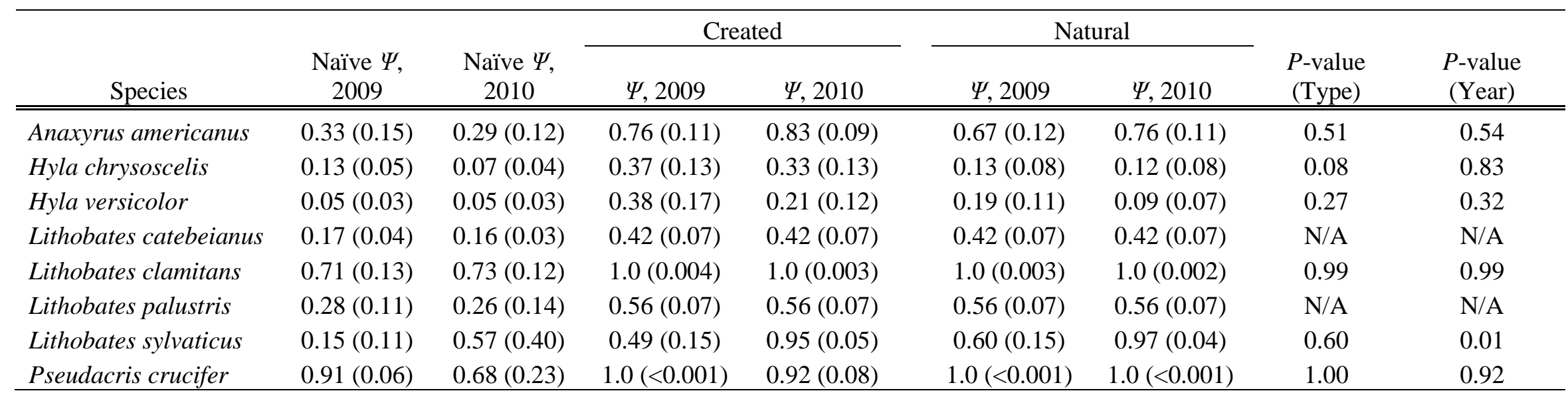


Table 3. Species richness estimates (+/- $1 \mathrm{SE})$ of calling adult anurans recorded in created and natural wetlands of the Central Appalachians during 2009 and 2010.

\begin{tabular}{cc}
\hline Wetland Type by Year & $\begin{array}{c}\text { Species } \\
\text { Richness }\end{array}$ \\
\hline \hline Created 2009 & $4.1(0.6)$ \\
Created 2010 & $3.8(0.6)$ \\
Natural 2009 & $3.1(0.5)$ \\
Natural 2010 & $2.8(0.5)$ \\
\hline
\end{tabular}




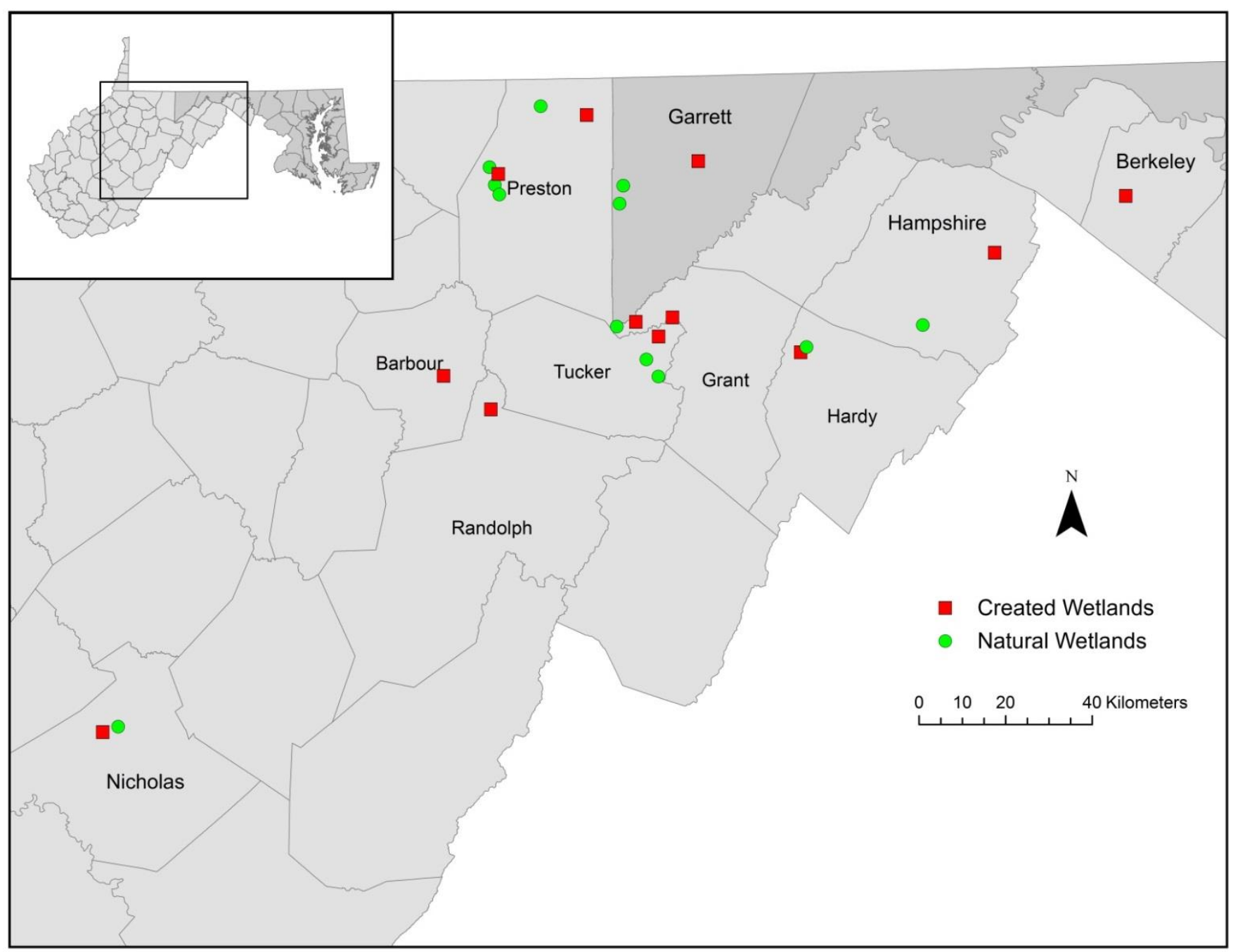

Figure 1. Locations of natural $(n=12)$ and created $(n=12)$ wetlands used to study occupancy of calling adult anurans in the Central Appalachians of West Virginia and Maryland. 


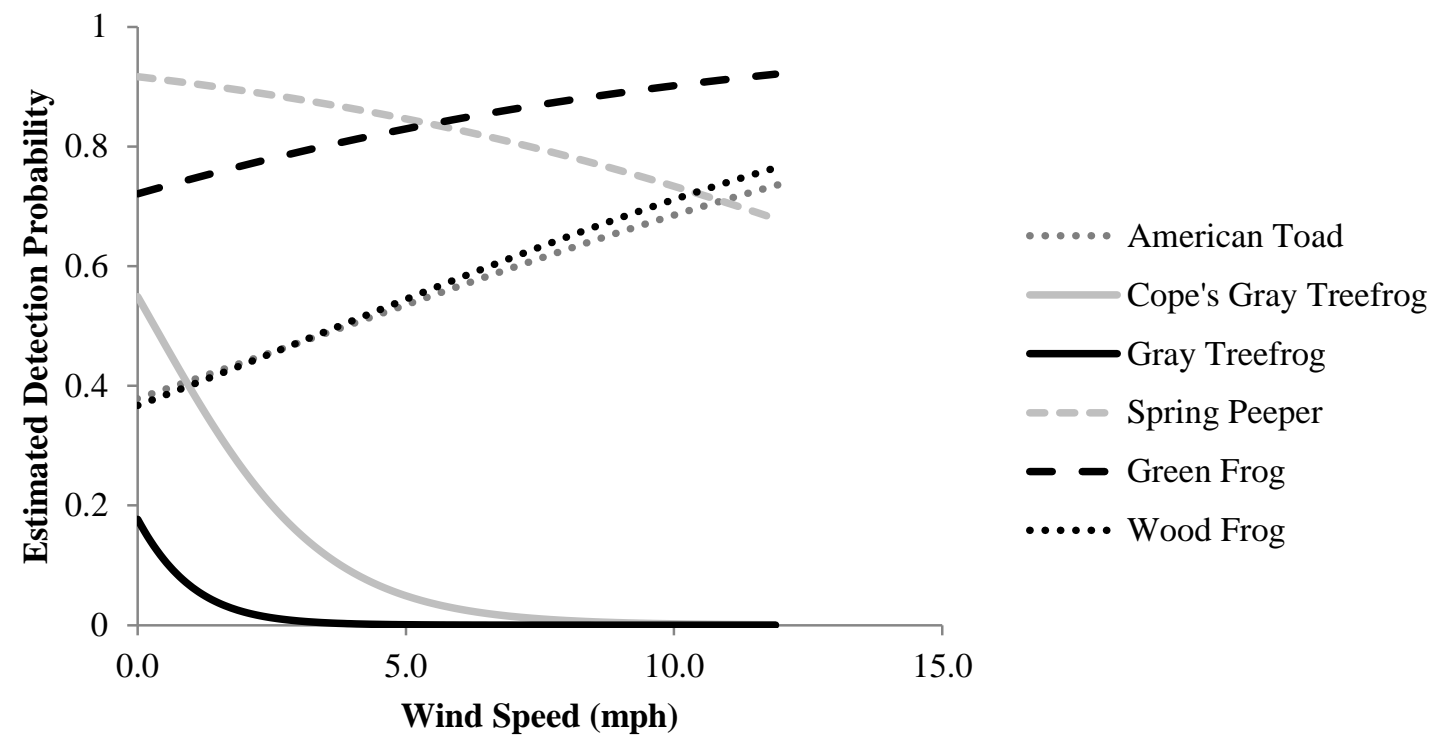

Figure 2. Estimated detection probability as a function of wind speed (at the mean of all other environmental variables) for calling adult anurans encountered in created and natural wetlands of the Central Appalachians during 2009 and 2010. 


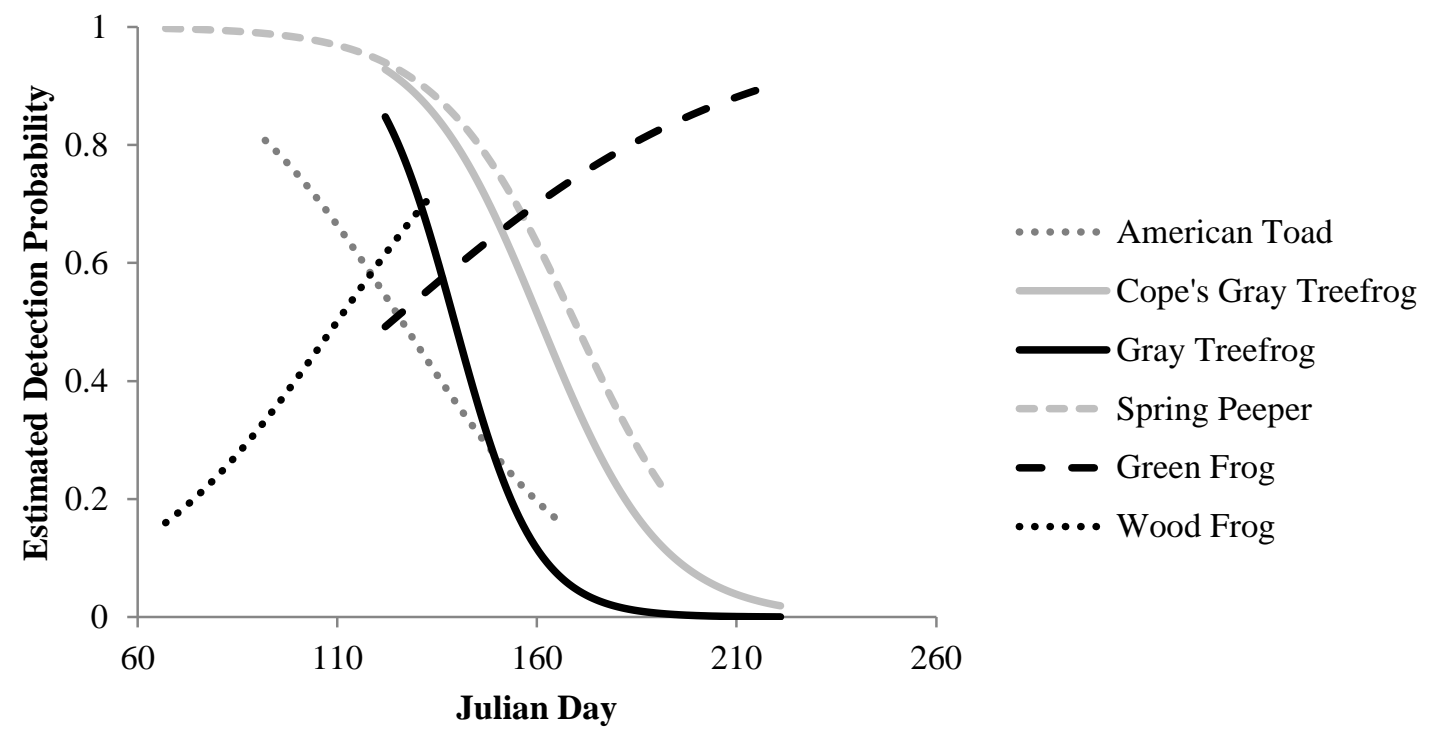

Figure 3. Estimated detection probability as a function of Julian day (at the mean of all other environmental variables) for calling adult anurans encountered in created and natural wetlands of the Central Appalachians during 2009 and 2010. 


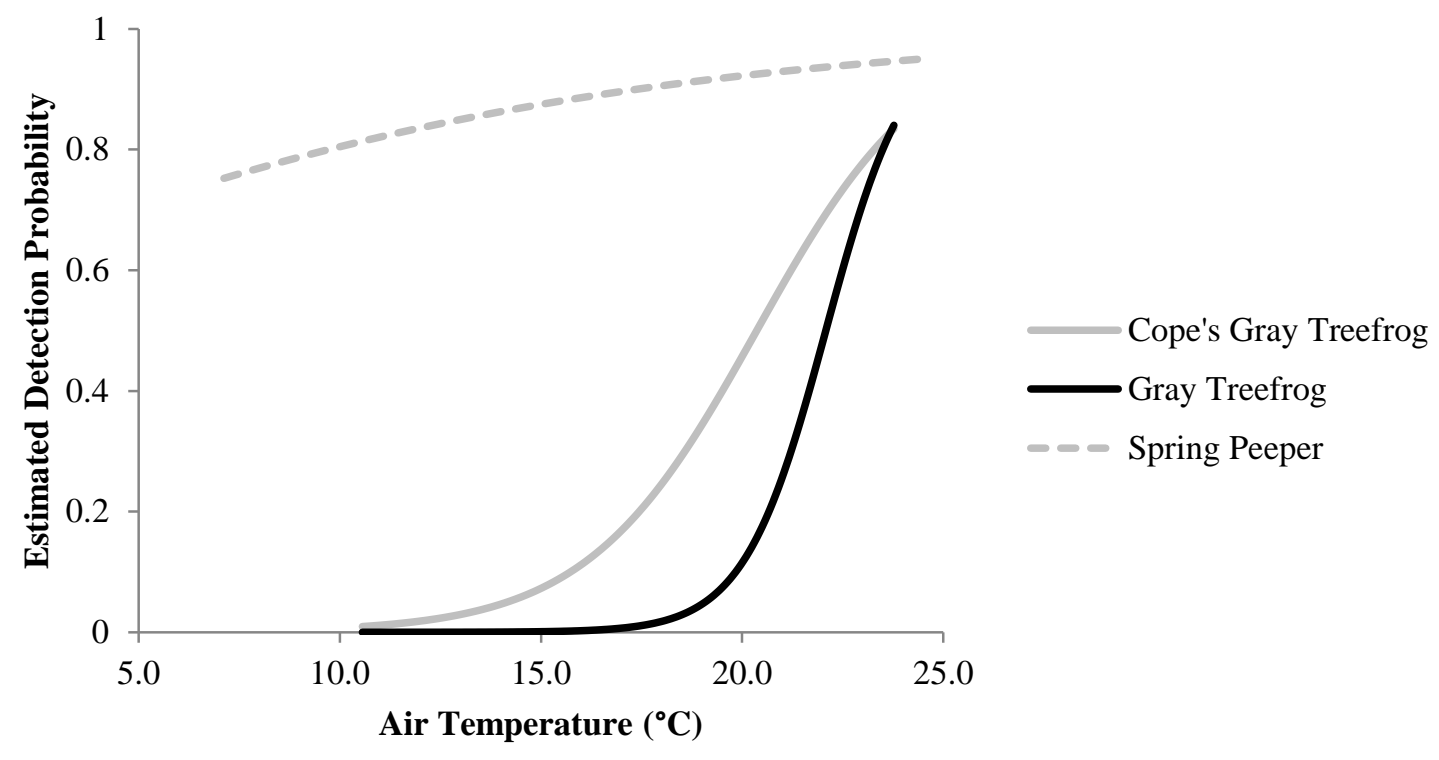

Figure 4. Estimated detection probability as a function of air temperature (at the mean of all other environmental variables) for calling adult anurans encountered in created and natural wetlands of the Central Appalachians during 2009 and 2010. 


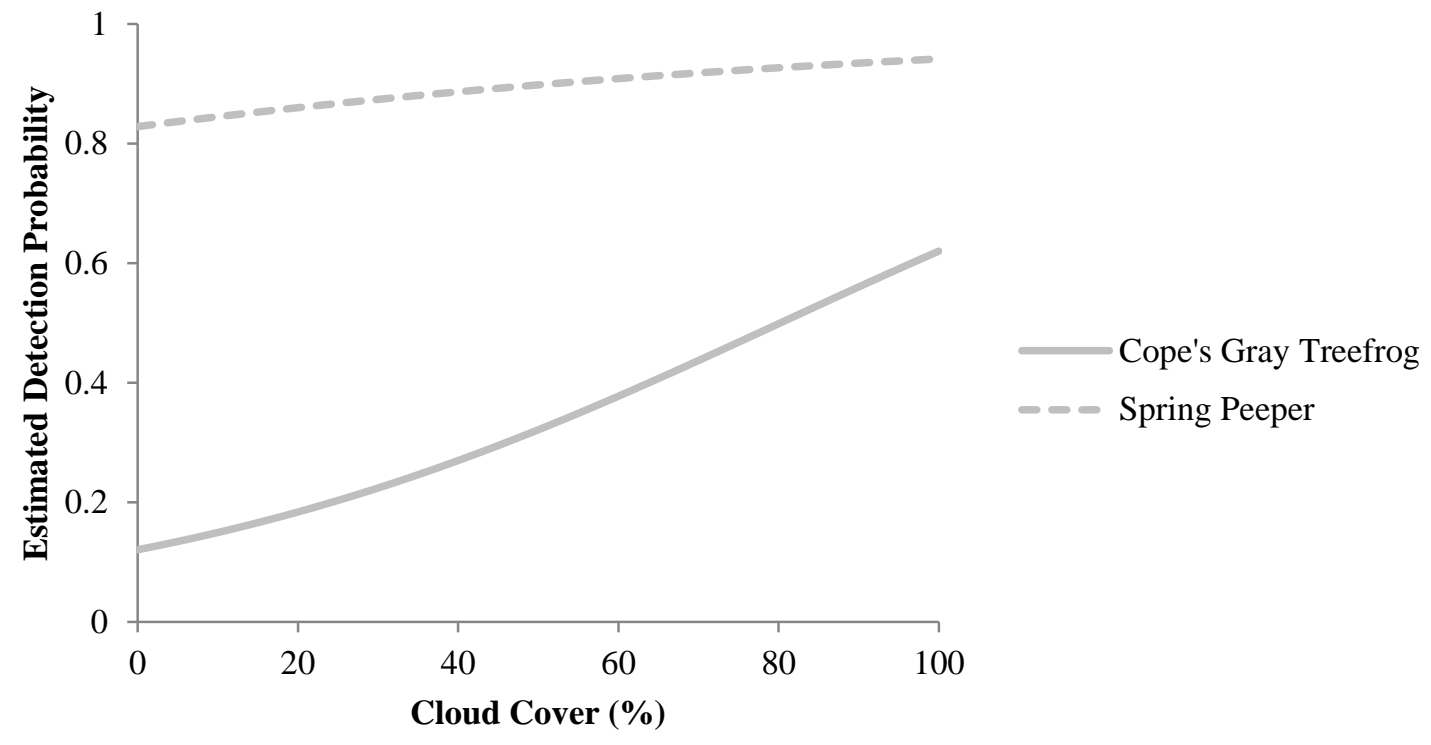

Figure 5. Estimated detection probability as a function of cloud cover (at the mean of all other environmental variables) for calling adult anurans encountered in created and natural wetlands of the Central Appalachians during 2009 and 2010. 


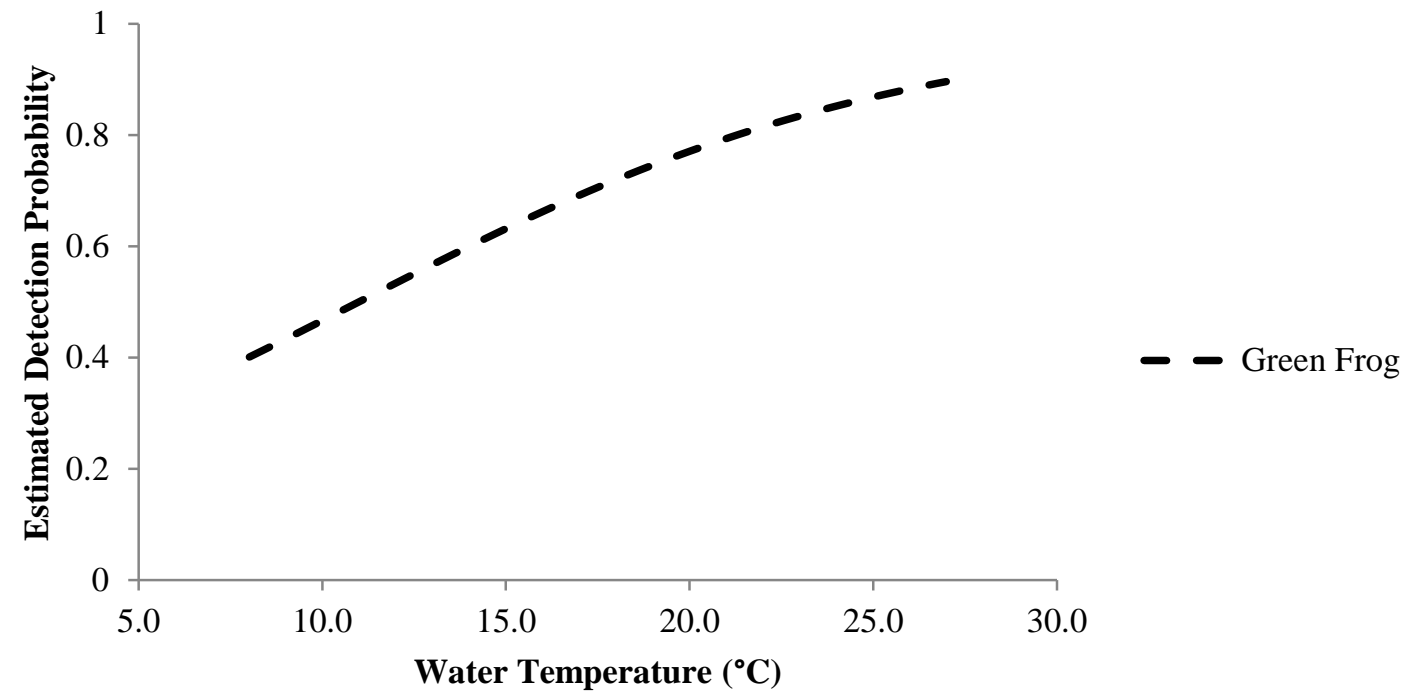

Figure 6. Estimated detection probability as a function of water temperature (at the mean of all other environmental variables) for calling adult anurans encountered in created and natural wetlands of the Central Appalachians during 2009 and 2010. 


\title{
CHAPTER IV
}

\section{FUNCTIONAL EQUIVALENCY OF CREATED AND NATURAL WETLANDS: DIET COMPOSITION OF RED-SPOTTED NEWTS (NOTOPHTHALMUS VIRIDESCENS VIRIDESCENS)}

\author{
Gabriel F. Strain $^{1 *}$, Dr. Philip J. Turk ${ }^{2}$, and Dr. James T. Anderson ${ }^{1}$ \\ ${ }^{1}$ West Virginia University, Division of Forestry and Natural Resources, PO Box 6125, \\ Morgantown, WV 26506-6125 \\ *Corresponding Author e-mail: gstrain54@yahoo.com \\ ${ }^{2}$ West Virginia University, Department of Statistics, \\ PO Box 6330, Morgantown, WV 26506-6125
}

Written in the style of:

Wetlands Ecology and Management 


\title{
Functional equivalency of created and natural wetlands: diet composition of red-spotted newts (Notophthalmus viridescens viridescens)
}

\author{
Gabriel F. Strain ${ }^{* 1}$, Philip J. Turk ${ }^{2}$, and James T. Anderson ${ }^{1,3}$ \\ ${ }^{1}$ Division of Forestry and Natural Resources, West Virginia University, P.O. Box 6125, \\ Morgantown, WV 26506-6125, USA \\ ${ }^{2}$ Department of Statistics, West Virginia University, P.O. Box 6330, Morgantown, WV 26506, \\ USA \\ ${ }^{3}$ Environmental Research Center, West Virginia University, P.O. Box 6125, Morgantown, WV \\ 26506-6125, USA \\ *Corresponding author: gstrain54@ yahoo.com, 443-938-2169 (phone), 304-293-2441 (fax)
}

\begin{abstract}
Evaluating the adequacy of created wetlands to replace functions of lost natural wetlands is important because wetland mitigation is a major tool used to offset wetland losses. However, measurements such as vegetative cover and wildlife presence may not be evidence enough that created wetlands are functioning properly and thus, examining the ecology of wetland biota such as amphibians may be a more useful surrogate for function. Our objectives were to measure the diet composition of adult red-spotted newts (Notophthalmus viridescens viridescens) and compare the selection of prey by newts between created and natural wetlands. Newts were trapped during the spring and summer of 2009 and 2010, and the stomach contents of 149 newts were obtained with gastric lavage. Invertebrate prey availability was obtained within a $5 \mathrm{~m}$
\end{abstract}


radius of each captured newt. Selection of prey by newts was nonrandom, but was only minimally affected by wetland type. Both dietary breadth and prey selection were affected primarily by time of year, likely driven by temporal variation in invertebrate abundance. Our results suggest that the function of providing an adequate prey base for a generalist wetland predator such as the red-spotted newt is being fulfilled for the created wetlands that we examined.

Key-words Compensatory mitigation, Habitat, Macroinvertebrates, Predator-prey, Salamanders, Wetland function, Wetland loss, Wildlife

\section{Introduction}

Wetlands provide important ecosystem services, such as storage, assimilation of nutrients, and habitat for wildlife (Dahl and Johnson 1991; Tiner 2002; Balcombe et al. 2005a; Mitsch and Gosselink 2007). Many amphibian species spend all or part of their life cycle in wetlands because wetlands offer a source of food, protection, and breeding habitat (Gibbons 2003). In turn, amphibians provide an abundant and high-energy food source for larger predators such as birds and mammals (Davic and Welsh 2004).

More than 53\% of the wetland area in the United States has been lost since the 1780s (Dahl 1990) due to drainage, dredging, hydrologic alterations, and water pollution related to activities such as agriculture, development, and mining (Mitsch and Gosselink 2007). This loss threatens the biodiversity of amphibians through habitat destruction and loss of wetland connectivity (Semlitsch and Bodie 1998; Gallant et al. 2007). The United States has established a 
policy of "no net loss" of wetlands (Turner et al. 2001). Although avoidance of wetland impacts is preferred, compensatory mitigation, which is the replacement or compensation of wetland area and function when permitted damage to natural wetlands is unavoidable, is a major tool used to accomplish this goal (Zedler 1996; Cole and Shafer 2002). However, the success of wetland mitigation is equivocal. Although recent studies demonstrate that emergent and scrub-shrub wetlands have increased in area in the United States, losses still outweigh gains in overall wetland area (Dahl 2011) and evidence suggests that certain functions such as nutrient cycling are not being adequately mitigated (Hossler et al. 2011).

In most cases, the success of created wetlands is judged by examining parameters such as hydrology, vegetative cover, or the presence of wildlife; however, the structural similarity of a created wetland to a natural wetland does not necessarily mean that the created wetland functions in the same way (Campbell et al. 2002; Jelinski et al. 2011). For instance, adult anurans may call and breed at wetlands, but mortality of eggs or larvae may result in reproductive failure (Petranka et al. 2003). Therefore, assessment of the functions that created wetlands provide may be a more suitable approach to gauge the success of wetland creation.

Factors that influence habitat quality of wetlands for wildlife include vegetation structure, hydroperiod, and the occurrence of food resources and predators (Anderson and Gutzwiller 1994). These factors in turn affect life history aspects of wildlife populations such as reproduction, survival, recruitment, growth, and diet. Examination of these aspects can assist in determining whether or not created wetlands are fulfilling this vital function. Balcombe $e t$ al. (2005b) found that created and natural wetlands in West Virginia supported similar macroinvertebrate assemblages and thus concluded that the created wetlands they examined 
provided adequate resources for wildlife such as waterfowl and anurans. The next step is to test this conclusion by examining the diet of amphibians inhabiting both created and natural wetlands.

Amphibians are predatory wetland inhabitants that can have considerable impact on the structure of wetland invertebrate communities (Smith et al. 2004), but little work has been done to examine the diet composition of amphibians in created wetlands. Red-spotted newts (Notophthalmus viridescens viridescens Rafinesque) have one of the largest ranges of any amphibian in the United States (Hunsinger and Lannoo 2005), are common in many types of wetlands throughout the Central Appalachian region (Gates and Thompson 1982), and are often the most significant predator in wetland systems (Burton 1977). For these reasons, N. v. viridescens makes an ideal study organism. Additionally, the use of such a well-studied species enabled us to gain insight into how the diets of individuals in created wetlands differ from those feeding in natural wetlands. The specific objectives of this study were to compare the diet composition and the use and selection of invertebrate prey items by adult $N$. v. viridescens between created and natural wetlands.

\section{Material and methods}

Study Area

Six created $(\overline{\mathrm{x}}=6.1$ ha, $\mathrm{SE}=1.4)$ and six reference $(\overline{\mathrm{x}}=2.5$ ha, $\mathrm{SE}=0.6)$ wetlands were selected for study (Fig. 1, Table 1). The majority of the created wetlands used in this study were constructed by the West Virginia Division of Highways to offset losses to natural wetlands during the construction of two major highways (Gingerich and Anderson 2011). Excavated 
wetland basins were lined with clay and topsoil, and seeded and planted with herbaceous and woody plant species, respectively. Each created wetland was paired with a natural wetland similar in elevation (created $\overline{\mathrm{x}}=683.5 \mathrm{~m}, \mathrm{SE}=105.8$; natural $\overline{\mathrm{x}}=667.2 \mathrm{~m}, \mathrm{SE}=109.8$ ) and underlying geology, factors that are thought to affect wetland habitat (Diehl and Behling 1982; Weakley and Schafale 1994; Halsey 1997; Bledsoe and Shear 2000; Francl et al. 2004). The majority of created wetlands tend to be dominated by open water (Cole and Brooks 2000), and created wetlands in West Virginia also have a large proportion of open water compared to natural wetlands (Balcombe et al. 2005b). Thus, historic beaver (Castor canadensis)-created wetlands may approximate the conditions of these created wetlands as amphibian habitat more so than other wetland types in the state, and we thus selected these as natural wetlands.

\section{Newt Sampling}

Newts were collected with funnel traps (Micacchion 2002) and dipnet sweeps. We placed traps only along the perimeter of the wetland, ensuring that the traps were placed such that a portion of the trap was not submerged, allowing any captured adult amphibians to breathe. After determining the approximate perimeter (in meters) of each wetland from aerial photographs using ArcMAP 10.0 (ESRI, California, USA), we randomly chose 15 positions along the perimeter, and placed one trap at each of these 15 positions. We tethered traps to a wooden stake with fishing line to prevent them from washing away during high water events. Traps were opened once every month from March through August in 2009 and 2010. Traps remained open approximately 24 hours to maximize captures and to minimize mortality (Micacchion 2002). We visited paired sites as closely in time as possible to open the traps, and then returned the 
following day at approximately the same time to check and close the traps. We took the dipnet sample concurrently with trap checking. At each trap, we took a standardized dipnet sweep of approximately $1 \mathrm{~m}^{2}$ at a randomly selected spot within a $5 \mathrm{~m}$ radius of the trap.

\section{Gastric Lavage}

Immediately upon removal from funnel traps or capture with dipnets, we flushed each newt's stomach by inserting a small catheter attached to a water-filled 10cc syringe through the mouth into the stomach (Legler and Sullivan 1979; Griffiths 1986). We positioned individuals with the head down toward a collecting container (Mahan and Johnson 2007), and gently squeezed the syringe plunger, forcing water into the stomach which forced out the stomach contents. Stomach contents were placed in $95 \%$ ethanol, and each sample was given a unique code. We sexed newts (Petranka 1998) and released them at the site of capture. We identified stomach contents to the lowest practical taxonomic level, and calculated aggregate percentages of numbers (Litvaitis et al. 1994).

\section{Invertebrate Sampling}

Invertebrates were sampled using three randomly selected $1 \mathrm{~m}^{2}$ quadrats per individual collected within $5 \mathrm{~m}$ and $\leq 30 \mathrm{~min}$ of newt collection (Anderson et al. 2000). We swept the water surface, column, and benthos within each quadrat. We identified invertebrates to the lowest

practical taxonomic level (Table 2), and calculated aggregate percentages of numbers (Litvaitis et al. 1994). 


\section{Statistical Analysis}

We calculated the dietary breadth (DB) of each newt, following Anderson et al. (1999), as:

$$
\mathrm{DB}=\left(1 / \Sigma p^{2}\right)^{*} 1 / n
$$

where $p=$ proportion of the $i^{\text {th }}$ diet category consumed, and $n=$ number of categories. We fit a factor effects analysis of variance (ANOVA) model and included as factors wetland type (created or natural), month (March through August), and sex (male or female); we constructed a contrast to examine the effect of season (spring or summer) on dietary breadth. Because of small sample sizes, we pooled captures across years for analyses. We used a significance level of 0.05 to test the null hypothesis of no difference.

Aebischer et al. (1993) originally designed compositional analysis for habitat analysis, but they also suggested its utility for diet data and researchers have used it for this purpose (e.g., Brickle and Harper 1999; Anderson et al. 2000). We used this method to determine if amphibians were consuming invertebrates in proportion to availability between wetland types, month, season, and sex, and followed the methodology of Aebischer et al. (1993). For the test of diet selection, we calculated log-ratios by dividing proportional use and availability of each prey category by the proportional use and availability of a reference prey category, and then generated pairwise comparisons of diets using randomization procedures. We replaced missing values following the weighted mean lambda approach of Aebischer et al. (1993), in which values were replaced by the mean of present values for a particular log-ratio (i.e., invertebrate taxa). Following this we calculated a mean lambda by weighting each component of that lambda by the number of present values. To reduce potential bias caused by unequal sample size of 
invertebrates in each individual's stomach or availability sample, we also weighted the log-ratios derived from each individual's diet composition using the total number of invertebrates in that individual's stomach. We used a significance level of 0.05 for the test of diet selection.

We fit multiple univariate factor effects ANOVA models for the 28 different responses (28 unique pairings of eight prey categories). We included wetland type, month, and sex as factors; we constructed a contrast to examine the effect of season. To keep models as simples as possible, we did not include interaction terms. When evidence of non-normality was present, we used a global rank transformation on the log-ratios. Due to the large number of comparisons in this analysis and the concomitant increase in the probability of committing a Type I error, we used a significance value of 0.01 in testing all null hypotheses (Zar 1999). We compared the differences of level means for each factor using t-tests. We used SAS version 9 for Windows (SAS Institute, North Carolina, USA) for all analyses.

\section{Results}

We performed gastric lavage on $149 \mathrm{~N}$. v. viridescens; 61 newts (40 males and 21 females) from created wetlands $(\overline{\mathrm{x}}=10, \mathrm{SE}=4.6$, range $=0-45)$, and 88 newts ( 66 males and 22 females) from natural wetlands $(\overline{\mathrm{x}}=15, \mathrm{SE}=6.1$, range $=0-31)$. Ten stomachs $(7 \%)$ were empty (four from created wetlands and six from natural wetlands), and these newts were thus omitted from analyses. Ninety-nine families (all insects and molluscs) and orders (most other invertebrates) were present in dipnet samples, and $55.6 \%$ of these were present in stomach samples. Data were pooled into eight broad categories for analysis: Annelida, aquatic Insecta, 
Collembola, Hydrachnidia, macrocrustacea, Mollusca, terrestrial invertebrates, and zooplankton (Table 2).

Aquatic insects accounted for the highest mean percent occurrence in newt stomachs from both created (41\%) and natural (49\%) wetlands (Fig. 2). Zooplankton had the second highest mean percent occurrence in both created (19.8\%) and natural (24.3\%) wetlands. The remaining categories occurred less frequently (1-16.8\%).

Mean dietary breadth of newts inhabiting created wetlands $(0.12, \mathrm{SE}=0.01)$, was similar to that of natural wetlands $(0.11, \mathrm{SE}=0.01)(\mathrm{p}>0.05)$. It was similar between male $(\overline{\mathrm{x}}=0.12$, $\mathrm{SE}=0.01)$ and female $(\overline{\mathrm{x}}=0.11, \mathrm{SE}=0.01)$ newts $(\mathrm{p}>0.05)$. Significant differences were present between spring and summer and individual months $(\mathrm{p}<0.05$, Fig. 3). Specifically, the dietary breadth of newts was significantly higher in July than in March, April, and May, and was also higher in June compared to May. However, the dietary breadth estimates each month were similarly low (ranging from 0.10 to 0.14 ).

Diet selection of $N . v$ viridescens was not random (lambda $=0.36, \mathrm{p}=0.001)$; newts did not select prey in proportion to availability (Table 3). For all newts, the compositional analysis ranked prey categories (from most preferred to least preferred) in the order: zooplankton > aquatic Insecta $>$ Collembola $>$ terrestrial invertebrates $>$ macrocrustacea $>$ Mollusca $>$ Hydrachnidia > Annelida. Several pairwise comparisons of prey category ranks were significant (Table 4). For instance, although zooplankton was ranked as the most preferred category and is selected significantly more than Annelida, Hydrachnidia, macrocrustacea, and Mollusca, it is statistically similar to aquatic insects, collembolans, and terrestrial invertebrates. 
Several factors influenced diet selection by $N$. v. viridescens. The selection of macrocrustacea relative to aquatic Insecta depended on wetland type (created or natural), because although macrocrustaceans were avoided in both wetland types, there was a stronger avoidance of macrocrustaceans in created wetlands (Table 5). Season influenced the selection of zooplankton relative to Annelida, as annelids were more strongly avoided in spring compared to summer. Several differences were apparent with respect to month: Annelids were avoided more strongly than macrocrustaceans in July than in April. Compared to June and July macrocrustaceans were avoided relative to Annelida in August. In July aquatic insects were avoided compared to Hydrachnidia, but were preferred in March. Compared to macrocrustacea, aquatic insects were more strongly avoided in March than in April, July, and May. Aquatic insects were preferred over molluscs in April compared to July and May. In March aquatic insects were preferred over molluscs, but this relation was reversed in July. All other pairwise comparisons were nonsignificant. These results suggest that selection of prey by $N$. v. viridescens is affected mostly by variation in month, only minimally by the type of wetland and season, and is similar between males and females.

\section{Discussion}

Diet composition and selection of prey by $N$. v. viridescens was overall similar between created and natural wetlands. Although we are not aware of any other studies that specifically examined the diet of an amphibian predator inhabiting created wetlands, other studies have demonstrated that created wetlands often have invertebrate communities that are similar to natural wetlands, suggesting that an adequate prey base is being provided in created wetlands 
(Balcombe et al. 2005b). Although invertebrate communities in Minnesota wetlands were affected by fish and plant abundance and water depth, communities were similar between natural and restored wetlands (Zimmer et al. 2000). In a study of West Virginia wetlands, many of which were used in the present study, familial richness, diversity, density, and biomass of invertebrates was similar between created and natural wetlands (Balcombe et al. 2005b). Studies indicate that colonization of created wetlands by invertebrates is relatively rapid (Stanczak and Keiper 2004), thus providing prey for colonizing amphibians and other predators of invertebrates. The mean age of the created wetlands at the initiation of the present study was 15 years, and it appears that adequate time had passed for the created wetlands in our study to develop invertebrate communities. Our results suggest that the function of providing an adequate prey base for a generalist wetland predator is being fulfilled for the wetlands that we examined.

The few studies that have investigated the diets of predators inhabiting created wetlands have focused primarily on fish in created and restored estuarine wetlands. Cohen and Bollens (2008) found that the diets of Mississippi silversides (Menidia audens) and yellowfin gobies (Acanthogobius flavimanus) inhabiting 10- and 50-year old restored salt marshes in California were similar to the diets of fish from a natural marsh. The authors concluded that the similarity of diets signified that similarly adequate prey resources were available in both natural and restored marshes. In contrast, the diet of mummichogs (Fundulus heteroclitus) differed between created and natural North Carolina salt marshes (Moy and Levin 1991), and juvenile chinook salmon (Oncorhynchus tshawytscha) diets were different between restored and natural salt marshes in Oregon (Gray et al. 2002). Both of these studies determined that invertebrate prey resources differed between wetland types, possibly leading to the decreased abundance of fishes 
in created and restored wetlands that both studies observed. Moy and Levin (1991) suggested that differences in invertebrates between the two wetland types were due to differences in substrate composition. Scatolini and Zedler (1996) found that natural salt marshes in California had two to three times the abundance of invertebrates found in created marshes, and the authors suggested that coarse sediment and low vegetative cover in created wetlands may have been responsible for differences. Invertebrate communities were similar between the created and natural wetlands in our study (Balcombe et al. 2005b), and we found that diet composition and prey selection of $N$. v. viridescens was similar between wetland types. Approximately $50 \%$ of the newts we collected were captured with funnel traps left overnight, and therefore newts may have been consuming invertebrates that were in the funnel traps. We assumed that the invertebrate fauna in funnel traps was reasonably similar in composition to the invertebrates in the wetland, especially considering our low taxonomic resolution.

Although aquatic invertebrates are generally unresponsive to environmental variation (Batzer et al. 2004), they are negatively influenced by extremes of hydroperiod (Schneider and Frost 1996; Fairchild et al. 2003), pH, conductivity, and other aquatic parameters (Merovich and Petty 2010). Everhart Seep, a wetland created to receive treated acid mine drainage runoff, was consistently acidic $(\mathrm{pH}<3)$ and few invertebrates were found during newt trapping attempts, and no newts or other vertebrates were ever observed. We suggest that creating wetlands with hydroperiods and water quality that fall within reasonable limits will ensure successful invertebrate establishment and adequate resources for higher trophic levels that prey upon aquatic invertebrates. 
Our results suggest that among the factors we examined - wetland type, month, and sex the main source of variation in newt diets was time of year. This outcome is reasonable, because $N$. v. viridescens is a generalist predator and studies have demonstrated that aquatic invertebrate abundances vary throughout the year, and thus their availability to predators fluctuates. This temporal variation is also consistent with other studies. Although there were some differences present between created and natural wetland benthic invertebrate communities in Texas, greater differences were found between seasons (Brusati et al. 2001). In a study of seasonal forested wetlands in Minnesota, a large proportion of variation in invertebrate communities was due to sampling date, which coincided with shifts in abundance of certain taxa over time (Miller et al. 2008). These shifts are likely due to life history changes of certain taxa (Batzer and Wissinger 1996) and hydrological factors such as hydroperiod changes and stratification (Hart 1985). Because studies have found temporal shifts in invertebrate abundance, and because we observed temporal shifts in prey selection by $N$. v. viridescens, we hypothesize that the invertebrate communities in both the natural and created wetlands in our study undergo similar temporal shifts in abundance, and newts respond to this shift by temporally modifying their selection of prey. We did not test for shifts in invertebrate abundance, but it merits further investigation. However, in contrast to Burton's (1977) hypothesis that newts prey on invertebrates in proportion to their availability, the results of our compositional analysis provide evidence that newts forage selectively throughout the year.

The diet composition of $N$. v. viridescens in our study was similar to that found in other studies that have examined stomach contents. Aquatic insects comprised the largest percentage of stomach contents from newts in a Pennsylvania pond, with dipterans (larvae and pupae), 
trichopterans, and ephemeropterans comprising 50\%, 29\%, and $21 \%$, respectively, of the insects observed (Ries and Bellis 1966). In a study of newts in a New Hampshire lake, aquatic insects were the most frequently consumed prey item in all months except October, when cladocerans dominated (Burton 1977). Percent occurrence of prey items in stomachs from our study was also dominated by aquatic insects, and dipterans and ephemeropterans comprised the majority of items (49\% and $25 \%$, respectively), but trichopterans occurred much more infrequently $(0.5 \%$ of the total). The most frequently occurring dipteran family in Pennsylvania newt stomachs was Tendipedidae (Ries and Bellis 1966), which we did not find in any of our wetlands or stomach contents; chironomid larvae dominated the stomach contents of newts in our study $(52 \%$ of dipterans). The dipterans found in newt stomachs in our study also included adults of Chironomidae, Chloropidae, Dolichopodidae, Empididae, Ephydridae, and Sciaridae (8\% of dipterans). The presence of adult flies in stomach contents of aquatic adults provides additional evidence that red-spotted newts feed not only from the benthos and water column, but also from the water surface (Ries and Bellis 1966).

Ries and Bellis (1966) stated that cladocerans were unimportant prey due to their small size, but under certain conditions $N . v$. viridescens may prefer cladocerans over larger prey such as amphipods (Attar and Maly 1980). In our study, zooplankton (comprised of 74\% cladocerans) was the preferred prey, although not significantly more so than aquatic insects, collembolans, and terrestrial invertebrates. Burton (1977) found that cladocerans comprised a significant portion of the diet of newts inhabiting a New Hampshire lake, making up 97\% percent of the diet during October. It is interesting to note that ours is one of the few studies to report plecopterans in newt stomachs (see also Stewart et al. 2001); we found 55 individuals representing two 
families (Capniidae and Nemouridae) in 4 newt stomachs. The availability of plecopterans as prey is most likely due to the fact that all of the wetlands in our study receive input from at least one stream, allowing stonefly larvae to drift into the wetland.

Although newts are known to prey heavily upon amphibian larvae (Morin 1981; Wilbur et al. 1983; Smith 2006), amphibians did not constitute a large portion of the diet of red-spotted newts in our study (1.2\% of total prey consumed). Three newt stomachs contained a single unidentified ranid larvae, one stomach contained two ranid larvae, one stomach contained two salamander larvae (most likely $N . v$. viridescens), and two stomachs contained numerous unidentified amphibian eggs. Burton (1977) reported that predation on newt larvae was an important component of the adult diets during July (1.4\% of the diet) and August (4.4\%), but we did not observe a similar trend, as seven newts represented the total that preyed upon amphibians across both years of the study, and the largest proportion of amphibians consumed was $0.6 \%$ in April. It is worth noting that a large number of newts in our study were found to have consumed their shed skin (exuvia found in $21 \%$ of stomachs), which is similar to that reported elsewhere (MacNamara 1977).

We conclude that red-spotted newts are selecting and consuming prey similarly between the natural and created wetlands in our study, most likely due to the similarity of invertebrate communities reported by Balcombe et al. (2005b). This provides evidence that the created wetlands we examined provide adequate prey resources, an important component of wildlife habitat and a vital wetland function. As generalist predators (Hunsinger and Lannoo 2005; Petranka 1998), the diet of adult red-spotted newts is most likely similar to other generalist aquatic amphibian inhabiting wetlands; we speculate that the diets of other generalist amphibian 
predators are also similar between created and natural wetlands. However, further research should examine the diets of other amphibians inhabiting created wetlands, especially those species that may be specialized predators (Anderson et al. 1999; Macale et al. 2008). We suggest that observed lack of amphibians or decreased abundances in created wetlands is most likely not due to lack of prey resources and more likely due to other biotic or abiotic factors such as inappropriate hydroperiod (Pechmann et al. 1989; Babbitt 2005; Shoo et al. 2011), presence of predatory fish (Hartel et al. 2007; Julian et al. 2006), or degraded landscape surrounding wetlands (Findlay and Houlahan 1997; Lehtinen et al. 1999).

\section{Acknowledgements}

We thank R. Gingerich, E. Miller, J. Pitchford, A. Nemeyer, B. Olejasz, N. McCoard, and several undergraduate technicians for their help in the field and laboratory. We also thank D. Hartman and E. Merriam for helping to identify invertebrates. Funding and logistical support was provided by the WVU Division of Forestry and Natural Resources through the McIntireStennis program, the West Virginia Division of Highways, the WVU Environmental Research Center, and the National Oceanic and Atmospheric Administration, and a student research grant to GFS from the South Atlantic Chapter of the Society of Wetland Scientists. We thank the Canaan Valley National Wildlife Refuge, Mt. Storm Power Station, The Nature Conservancy, and Potomac-Garrett State Forest for allowing us to use wetlands under their respective care. We received approval from the West Virginia University Animal Care and Use Committee to conduct research on red-spotted newts (protocol 08-1001). This is scientific article 3206 of the West Virginia University Agricultural and Forestry Experiment Station. 


\section{Literature Cited}

Aebischer NJ, Robertson PA, Kenward RE (1993) Compositional analysis of habitat use from animal radio-tracking data. Ecology 74:1313-1325

Anderson AM, Haukos DA, Anderson JT (1999) Diet composition of three anurans from the playa wetlands of northwest Texas. Copeia 1999:515-520

Anderson JT, Smith LM, Haukos DA (2000) Food selection and feather molt by nonbreeding American green-winged teal in Texas playas. J Wildl Manage 64:222-230

Anderson SH, Gutzwiller KJ (1994) Habitat evaluation methods. In:

Bookhout TA, (ed) Research and management techniques for wildlife and habitats, 5th ed. Wildlife Society, Bethesda pp. 592-606

Attar EN, Maly EJ (1980) A laboratory study of preferential predation by the newt Notophthalmus v. viridescens. Can J Zoolog 58:1712-1717

Babbitt KJ (2005) The relative importance of wetland size and hydroperiod for amphibians in southern New Hampshire, USA. Wetl Ecol Manage 13:269-279

Balcombe CK, Anderson JT, Fortney RH, Kordek WS (2005a) Wildlife use of mitigation and reference wetlands in West Virginia. Ecol Eng 25:85-99

Balcombe CK, Anderson JT, Fortney RH, Kordek WS (2005b) Aquatic macroinvertebrate assemblages in mitigated and natural wetlands. Hydrobiologia $541: 175-188$

Batzer DP, Palik BJ, Buech R (2004) Relationships between environmental characteristics and macroinvertebrate communities in seasonal woodland ponds of Minnesota. J N Am Benthol Soc 23:50-68 
Batzer DP, Wissinger SA (1996) Ecology of insect communities in nontidal wetlands.

Annu Rev Entomol 41:75-100

Bledsoe BP, Shear TH (2000) Vegetation along hydrologic and edaphic gradients

in a North Carolina Coastal Plain creek bottom and implications for restoration. Wetlands 20:126-147

Brickle NW, Harper DGC (1999) Diet of nestling corn buntings Milaria calandra in southern England examined by compositional analysis of faeces. Bird Study 46:319-329

Brusati ED, DuBowy PJ, Lacher TE, Jr. (2001) Comparing ecological functions of natural and created wetlands for shorebirds in Texas. Waterbirds 24:371-380

Burton TM (1977) Population estimates, feeding habits and nutrient and energy relationships of Notophthalmus v. viridescens, in Mirror Lake, New Hampshire. Copeia 1977:139-143

Campbell DA, Cole CA, Brooks RP (2002) A comparison of created and natural wetlands in Pennsylvania, USA. Wetl Ecol Manag 10:41-49

Cohen SE, Bollens SM (2008) Diet and growth of non-native Mississippi silversides and yellowfin gobies in restored and natural wetlands in the San Francisco Estuary. Mar EcolProg Ser 368:241-254

Cole CA, Brooks RP (2000) A comparison of the hydrologic characteristics of natural and created mainstem floodplain wetlands in Pennsylvania. Ecol Eng 14:221-231

Cole CA, Shafer D (2002) Section 404 wetland mitigation and permit success criteria in Pennsylvania, USA, 1986-1999. Environ Manage 30:508-515

Dahl TE (1990) Wetlands losses in the United States 1780's to 1980's. U.S. Department of the Interior, Fish and Wildlife Service, Washington, D.C. 
Dahl TE (2011) Status and trends of wetlands in the conterminous United States 2004 to 2009.

U.S. Department of the Interior; Fish and Wildlife Service, Washington, D.C.

Dahl TE, Johnson CE (1991) Status and trends of wetlands in the conterminous United States, mid-1970's to mid-1980’s. U.S. Department of the Interior, Fish and Wildlife Service, Washington, D.C.

Davic RD, Welsh HH, Jr. (2004) On the ecological role of salamanders. Annu Rev Ecol Evol S $35: 405-434$

Diehl JW, Behling RE (1982) Geologic factors affecting formation and presence of wetlands in the north central section of the Appalachian Plateaus Province of West Virginia. In: McDonald BR (ed) Proceedings of the symposium on wetlands of the unglaciated Appalachian region. West Virginia University, Morgantown, pp. 3-9.

Fairchild GW, Cruz J, Faulds AM, Short AEZ, Matta JF (2003) Microhabitat and landscape influences on aquatic beetle assemblages in a cluster of temporary and permanent ponds. J N Am Benthol Soc 22:224-240

Findlay CS, Houlahan J (1997) Anthropogenic correlates of species richness in southeastern Ontario wetlands. Conserv Biol 11:1000-1009

Francl KE, Ford WM, Castleberry SB (2004) Characterization of high elevation central Appalachian wetlands. Research Paper NE-725. U.S. Department of Agriculture, Forest Service, Northeastern Research Station, Newtown Square, PA

Gallant AL, Klaver RW, Casper GS, Lannoo MJ (2007) Global rates of habitat loss and implications for amphibian conservation. Copeia 2007:967-979

Gates JE, Thompson EL (1982) Small pool habitat selection by red-spotted newts in 
western Maryland. J Herpetol 16:7-15

Gibbons JW (2003) Terrestrial habitat: a vital component for herpetofauna of isolated wetlands. Wetlands 23:630-635

Gingerich RT, Anderson JT (2011) Decomposition trends of five plant litter types in mitigated and reference wetlands in West Virginia, USA. Wetlands 31:653-662

Gray A, Simenstad CA, Bottom DL, Cornwell TJ (2002) Contrasting functional performance of juvenile salmon habitat of recovering wetlands in the Salmon River estuary, Oregon, USA. Restor Ecol 10:514-526

Griffiths RA (1986) Feeding niche overlap and food selection in smooth and palmate newts, Triturus vulgaris and T. Helveticus, at a pond in mid-Wales. J Anim Ecol 55:201-214

Halsey L (1997) Climatic and physiographic controls on wetland type and distribution in Manitoba, Canada. Wetlands 17:243-262

Hart RC (1985) Seasonality of aquatic invertebrates in low-latitude and southern hemisphere inland waters. Hydrobiologia 125:151-178

Hartel T, Nemes S, Cogalniceanu D, Ollerer K, Schweiger O, Moga C, Demeter L (2007) The effect of fish and aquatic habitat complexity on amphibians. Hydrobiologia 538:173-182

Hossler K, Bouchard V, Fennessy MS, Frey SD, Anemaet E, Herbert E (2011) Nonet-loss not met for nutrient function in freshwater marshes: recommendations for wetland mitigation policies. Ecosphere 2:1-36

Hunsinger TW, Lannoo M (2005) Notophthalmus viridescens. In: Lannoo M (ed) Amphibian declines. University of California Press, Berkeley, pp. 889-894 
Jelinski NA, Kucharik CJ, Zedler JB (2011) A test of diversity-productivity models in natural, degraded, and restored wet prairies. Restor Ecol 19:186-193

Julian JT, CD Snyder, Young JA (2006) The use of artificial impoundments by two amphibian species in the Delaware Water Gap National Recreation Area. Northeast Nat $13: 459-468$

Legler JM, Sullivan LJ (1979) The application of stomach-flushing to lizards and anurans. Herpetologica 35:107-110

Lehtinen RM, Galatowitsch SM, Tester JR (1999) Consequences of habitat loss and fragmentation for wetland amphibian assemblages. Wetlands 19:1-12

Litvaitis JA, Titus K, Anderson EM (1994) Measuring vertebrate use of terrestrial habitats and food. In: Bookhout TA (ed) Research and management techniques for wildlife and habitats, $5^{\text {th }}$ ed. Wildlife Society, Bethesda, pp. 254-274

Macale D, Vignoli L, Carpaneto GM (2008) Food selection strategy during the reproductive period in three syntopic hylid species from a subtropical wetland of northeast Argentina. Herpetol J 18:49-58

MacNamara MC (1977) Food habits of terrestrial adult migrants and immature red efts of the red-spotted newt Notophthalmus viridescens. Herpetologica 33:127-132

Mahan RD, Johnson JR (2007) Diet of the gray treefrog (Hyla versicolor) in relation to foraging site location. J Herpetol 41:16-23

Merovich GT, Jr., Petty JT (2010) Continuous response of benthic macroinvertebrate assemblages to a discrete disturbance gradient: consequences for diagnosing streams. J N Am Benthol Soc 29:1241-1257 
Micacchion M (2002) Amphibian index of biotic integrity (AmphIBI) for wetlands. Final report to U.S. EPA Grant No. CD985875-01. Ohio Environmental Protection Agency. Wetland Ecology Group, Division of Surface Water, Columbus, OH, USA

Miller AT, Hanson MA, Church JO, Palik B, Bowe SE, Butler MG (2008) Invertebrate community variation in seasonal forest wetlands: implications for sampling and analyses. Wetlands 28:874-881

Mitsch WJ, Gosselink JG (2007) Wetlands, 4th ed. Wiley and Sons, Hoboken, NJ, USA

Morin PJ (1981) Predatory salamanders reverse the outcome of competition among three species of anuran tadpoles. Science 212:1284-1286

Moy LD, Levin LA (1991) Are Spartina marshes a replaceable resource? A functional approach to evaluation of marsh creation efforts. Estuaries 14:1-16

Pechmann JHK, Scott DE, Gibbons JW, Semlitsch RD (1989) Influence of wetland hydroperiod on diversity and abundance of metamorphosing juvenile amphibians. Wetl Ecol Manage 1:3-11

Petranka JW (1998) Salamanders of the United States and Canada. Smithsonian Institution Press, Washington, D.C., USA

Petranka JW, Murray SS, Kennedy CA (2003) Responses of amphibians to restoration of a southern Appalachian wetland: perturbations confound post-restoration assessment. Wetlands 23:278-290

Ries KM, Bellis ED (1966) Spring food habits of the red-spotted newt in Pennsylvania. Herpetologica 22:152-155

Scatolini SR, Zedler JB (1996) Epibenthic invertebrates of natural and constructed 
marshes of San Diego Bay. Wetlands 16:24-37

Schneider DW, Frost TM (1996) Habitat duration and community structure in temporary ponds. J N Am Benthol Soc 15:64-86

Semlitsch RD, Bodie JR (1998) Are small, isolated wetlands expendable? Conserv Biol $12: 1129-1133$

Shoo LP, Olson DH, McMenamin SK, Murray KA, Sluys MV, Donnelly MA, Stratford D, Terhivuo J, Merino-Viteri A, Herbert SM, Bishop PJ, Corn PS, Dovey L, Griffiths RA, Lowe K, Mahony M, McCallum H, Shuker JD, Simpkins C, Skerratt LF, Williams SE, Hero J (2011) Engineering a future for amphibians under climate change. J Appl Ecol 48:487-492

Smith KG (2006) Keystone predators (eastern newts, Notophthalmus viridescens) reduce the impacts of an aquatic invasive species. Oecologia 148:342-349

Smith LM, Gray MJ, Quarles A (2004) Diets of newly metamorphosed amphibians in west Texas playas. Southwest Nat 49:257-263

Stanczak M, Keiper JB (2004) Benthic invertebrates in adjacent created and natural wetlands in northeastern Ohio, USA. Wetlands 24:212-218

Stewart KD, Nelson CH, Duffield RM (2001) Occurrence of stoneflies (Plecoptera) in diet of red-spotted newt, Notophthalmus viridescens. Entomol News 112:225-229

Tiner RW (2002) In search of swampland. A wetlands sourcebook and field guide. Rutgers University Press, New Brunswick, NJ, USA

Turner RE, Redmond AM, Zedler JB (2001) Count it up by acre or function mitigation adds up to net loss of wetlands. National Wetlands Newsletter 23:5-16 
Weakley AS, Schafale MP (1994) Non-alluvial wetlands of the Southern Blue

Ridge - diversity in a threatened ecosystem. Water Air Soil Poll 77:359-383

Wilbur HM, Morin PJ, Harris RN (1983) Salamander predation and the structure of experimental communities: anuran responses. Ecology 64:1423-1429

Zar, J.H (1999) Biostatistical Analysis, 4th ed. Prentice Hall, Upper Saddle River, NJ, USA

Zedler JB (1996) Ecological issues in wetland mitigation: an introduction to the forum.

Ecol Appl 6:33-37

Zimmer KD, Hanson MA, Butler MG (2000) Factors influencing invertebrate communities in prairie wetlands: a multivariate approach. Can J Fish Aquat Sci 57:76-85 
Table 1. Attributes of natural $(n=6)$ and created $(n=6)$ wetlands used to study red-spotted newt diet selection in the Central Appalachians.

\begin{tabular}{lccccccc}
\hline \multicolumn{1}{c}{ Wetland } & Type & Pair & Year Built & Size (ha) & County & Elevation (m) & Geology \\
\hline \hline Camp 70 & Natural & 1 & -- & 0.02 & Tucker, WV & 952 & Shale \\
Elk Run & Created & 1 & 1981 & 3.8 & Grant, WV & 840 & Shale \\
Everhart Seep & Created & 2 & 2000 & 0.27 & Garrett Co, MD & 812 & Sandstone \\
Garrett State Forest & Natural & 2 & -- & 2 & Garrett Co, MD & 760 & Sandstone \\
Glade Run & Natural & 3 & -- & 2 & Tucker, WV & 962 & Limestone \\
VEPCO & Created & 3 & 1995 & 7 & Tucker, WV & 1036 & Sandstone \\
Leading Creek & Created & 4 & 1995 & 8.6 & Randolph, WV & 600 & Alluvium \\
Upper Deckers & Natural & 4 & -- & 2.6 & Preston, WV & 512 & Sandstone \\
Old Fields & Natural & 5 & -- & 4 & Hardy, WV & 292 & Shale \\
Walnut Bottom & Created & 5 & 1997 & 10 & Hardy, WV & 335 & Shale \\
Rail Trail & Natural & 6 & -- & 4.1 & Preston, WV & 525 & Shale \\
Sugar Creek & Created & 6 & 1995 & 6.8 & Barbour, WV & 478 & Sandstone \\
\hline
\end{tabular}


Table 2. Grouping of invertebrate families and orders for analysis of red-spotted newt diets (“"--“ indicates no further taxonomic resolution).

\begin{tabular}{|c|c|c|}
\hline Category & Order & Family \\
\hline \multirow{2}{*}{ Annelida } & Oligochaeta & -- \\
\hline & Hirudinea & -- \\
\hline \multirow{8}{*}{ Aquatic Insecta } & Coleoptera & $\begin{array}{l}\text { Chrysomelidae, Dytiscidae, Elmidae, Gyrinidae, Haliplidae, } \\
\text { Hydrophilidae, Lampyridae, Psephenidae, Scirtidae }\end{array}$ \\
\hline & Diptera & $\begin{array}{l}\text { Ceratopogonidae, Chaoboridae, Chironomidae, Culicidae, Dixidae, } \\
\text { Psychodidae, Simuliidae, Sciomyzidae, Tabanidae, Tipulidae }\end{array}$ \\
\hline & Ephemeroptera & Baetidae, Caenidae, Ephemerellidae, Leptophlebiidae, Siphlonuridae \\
\hline & Hemiptera & $\begin{array}{l}\text { Belostomatidae, Corixidae, Gerridae, Hebridae, Hydrometridae, } \\
\text { Mesoveliidae, Naucoridae, Nepidae, Notonectidae, Pleidae, Veliidae }\end{array}$ \\
\hline & Megaloptera & Corydalidae, Sialidae \\
\hline & Odonata & Aeshnidae, Coenagrionidae, Gomphidae, Lestidae, Libellulidae \\
\hline & Plecoptera & Capniidae, Nemouridae \\
\hline & Trichoptera & $\begin{array}{c}\text { Hydropsychidae, Hydroptilidae, Leptoceridae, Limnephilidae, } \\
\text { Phryganeidae, Polycentropodidae }\end{array}$ \\
\hline Collembola & & -- \\
\hline Hydrachnidia & & -- \\
\hline \multirow{3}{*}{ Macrocrustacea } & Amphipoda & -- \\
\hline & Decapoda & -- \\
\hline & Isopoda & -- \\
\hline \multirow{2}{*}{ Mollusca } & Bivalvia & Sphaeriidae \\
\hline & Gastropoda & Ancylidae, Lymnaeidae, Physidae, Planorbidae \\
\hline \multirow{9}{*}{$\begin{array}{l}\text { Terrestrial } \\
\text { Invertebrate }\end{array}$} & Arachnida & -- \\
\hline & Coleoptera & $\begin{array}{l}\text { Byrrhidae, Cantharidae, Carabidae, Cerambycidae, Chrysomelidae, } \\
\text { Coccinellidae, Curculionidae, Elateridae, Limnichidae, Staphylindae }\end{array}$ \\
\hline & Diptera & $\begin{array}{c}\text { Agromyzidae, Ceratopogonidae, Chironomidae, Chloropidae, } \\
\text { Dolichopodidae, Empididae, Ephydridae, Muscidae, Simuliidae, } \\
\text { Sciaridae, Sciomyzidae }\end{array}$ \\
\hline & Hemiptera & $\begin{array}{c}\text { Aphididae, Cicadellidae, Delphacidae, Enicocephalidae, Largidae, } \\
\text { Pentatomidae, Piesmatidae }\end{array}$ \\
\hline & Hymenoptera & Braconidae, Formicidae, Platygastridae, Scelionidae \\
\hline & Lepidoptera & Unknown Larvae \\
\hline & Orthoptera & Gryllacrididae, Gryllidae \\
\hline & Psocoptera & Psyllipsocidae \\
\hline & Thysanoptera & -- \\
\hline \multirow{3}{*}{ Zooplankton } & Cladocera & -- \\
\hline & Copepoda & -- \\
\hline & Podocopa & -- \\
\hline
\end{tabular}


Table 3. Mean percent use and availability $( \pm 1 \mathrm{SE})$ of invertebrate prey consumed by red-spotted newts inhabiting created and natural wetlands of the Central Appalachians.

\begin{tabular}{|c|c|c|c|c|c|c|c|c|}
\hline \multirow[b]{3}{*}{ Invertebrate Category } & \multicolumn{4}{|c|}{ Created Wetlands } & \multicolumn{4}{|c|}{ Natural Wetlands } \\
\hline & \multicolumn{2}{|c|}{ Use } & \multicolumn{2}{|c|}{ Availability } & \multicolumn{2}{|c|}{ Use } & \multicolumn{2}{|c|}{ Availability } \\
\hline & Mean $(\%)$ & SE & Mean $(\%)$ & SE & Mean $(\%)$ & SE & Mean $(\%)$ & SE \\
\hline Annelida & 2.69 & 1.82 & 8.78 & 2.15 & 1.61 & 0.90 & 14.59 & 2.44 \\
\hline Aquatic Insecta & 41.03 & 4.61 & 51.42 & 3.09 & 49.02 & 3.97 & 58.72 & 2.75 \\
\hline Collembola & 4.16 & 2.00 & 0.29 & 0.07 & 5.10 & 1.55 & 0.48 & 0.12 \\
\hline Hydrachnidia & 2.06 & 0.80 & 0.82 & 0.20 & 0.85 & 0.63 & 0.91 & 0.19 \\
\hline Macrocrustacea & 3.19 & 1.08 & 8.25 & 1.86 & 5.86 & 2.34 & 2.19 & 0.74 \\
\hline Mollusca & 16.84 & 3.91 & 11.81 & 1.88 & 2.56 & 0.90 & 5.38 & 0.96 \\
\hline Terrestrial Invertebrate & 10.32 & 2.94 & 3.73 & 0.92 & 10.76 & 2.40 & 2.66 & 0.76 \\
\hline Zooplankton & 19.77 & 3.65 & 14.91 & 2.43 & 24.31 & 3.35 & 15.12 & 1.97 \\
\hline
\end{tabular}


Table 4. Ranking matrix for red-spotted newts based on comparison of proportional prey use to proportions of available prey categories (a "+" sign indicates that the prey category in the row is used more than expected relative to the category in the column, whereas a "-" sign indicates that the prey category in the row is used less than expected relative to the option in the column; a triple sign indicates a significant departure from random use at $p=0.05$ ).

\begin{tabular}{lcccccccc}
\hline Invertebrate Category & $\mathrm{An}$ & $\mathrm{Aq}$ & $\mathrm{Co}$ & $\mathrm{Hy}$ & $\mathrm{MC}$ & $\mathrm{Mo}$ & $\mathrm{TI}$ & $\mathrm{Zo}$ \\
\hline \hline Annelida (An) & 0 & --- & --- & --- & --- & --- & --- & --- \\
Aq. Insecta (Aq) & +++ & 0 & + & +++ & + & +++ & + & - \\
Collembola (Co) & +++ & - & 0 & +++ & + & + & + & - \\
Hydrachnidia (Hy) & +++ & --- & --- & 0 & - & - & --- & --- \\
Macrocrustacea (MC) & +++ & - & - & + & 0 & + & --- & --- \\
Mollusca (Mo) & +++ & --- & - & + & - & 0 & --- & --- \\
Terrestrial Invert (TI) & +++ & - & - & +++ & +++ & +++ & 0 & - \\
Zooplankton (Zo) & +++ & + & + & +++ & +++ & +++ & + & 0 \\
\hline
\end{tabular}


Table 5. Significant $(p<0.01)$ pairwise comparisons of the mean differences of log-ratios from compositional analysis for wetland type, season, and month (for each prey category pairing the reference category is listed on the left, and a positive estimate indicates that the reference category is selected less than expected compared to the other category, whereas a negative estimate indicates that the reference category is selected more).

\begin{tabular}{|c|c|c|c|c|c|}
\hline Factor and Comparison & Estimate & SE & Estimate & SE & $p$-value \\
\hline Wetland Type & \multicolumn{2}{|c|}{ Created } & \multicolumn{2}{|c|}{ Natural } & \\
\hline Aq. Insecta - Macrocrustacea & -3.48 & 1.3 & -0.29 & 1.39 & 0.01 \\
\hline Season & \multicolumn{2}{|c|}{ Spring } & \multicolumn{2}{|c|}{ Summer } & \\
\hline Annelida - Zooplankton & 6.02 & 2.01 & 2.78 & 2.17 & 0.003 \\
\hline \multirow{3}{*}{ Annelida - Hydrachnidia } & \multirow{2}{*}{\multicolumn{2}{|c|}{ August }} & \multirow{2}{*}{\multicolumn{2}{|c|}{ July }} & \\
\hline & & & & & \\
\hline & -1.34 & 2.11 & 5.25 & 1.61 & 0.003 \\
\hline \multirow{6}{*}{ Annelida - Macrocrustacea } & \multicolumn{2}{|c|}{ April } & \multicolumn{2}{|c|}{ July } & \\
\hline & 0.88 & 1.14 & 5.53 & 1.53 & 0.005 \\
\hline & \multicolumn{2}{|c|}{ August } & \multicolumn{2}{|c|}{ July } & \\
\hline & -3.71 & 3.11 & 5.53 & 1.53 & 0.005 \\
\hline & \multicolumn{2}{|c|}{ August } & \multicolumn{2}{|c|}{ June } & \\
\hline & -3.71 & 3.11 & 6.42 & 2.5 & 0.007 \\
\hline \multirow{2}{*}{ Aq. Insecta - Hydrachnidia } & \multicolumn{2}{|c|}{ July } & \multicolumn{2}{|c|}{ March } & \\
\hline & 1.88 & 1.34 & -3.55 & 1.56 & 0.005 \\
\hline \multirow{6}{*}{ Aq. Insecta - Macrocrustacea } & \multicolumn{2}{|c|}{ April } & \multicolumn{2}{|c|}{ March } & \\
\hline & -1.92 & 1.17 & -5.82 & 1.61 & 0.008 \\
\hline & \multicolumn{2}{|c|}{ July } & \multicolumn{2}{|c|}{ March } & \\
\hline & 0.91 & 1.62 & -5.82 & 1.61 & 0.001 \\
\hline & \multicolumn{2}{|c|}{ March } & \multicolumn{2}{|c|}{ May } & \\
\hline & -5.82 & 1.61 & 0.3 & 1.48 & $<0.001$ \\
\hline \multirow{6}{*}{ Aq. Insecta - Mollusca } & \multicolumn{2}{|c|}{ April } & \multicolumn{2}{|c|}{ July } & \\
\hline & -4.02 & 0.98 & 2.05 & 1.41 & $<0.001$ \\
\hline & \multicolumn{2}{|c|}{ April } & \multicolumn{2}{|c|}{ May } & \\
\hline & -4.02 & 0.98 & 1.22 & 1.23 & $<0.001$ \\
\hline & \multicolumn{2}{|c|}{ July } & \multicolumn{2}{|c|}{ March } & \\
\hline & 2.05 & 1.71 & -5.14 & 1.47 & $<0.001$ \\
\hline
\end{tabular}




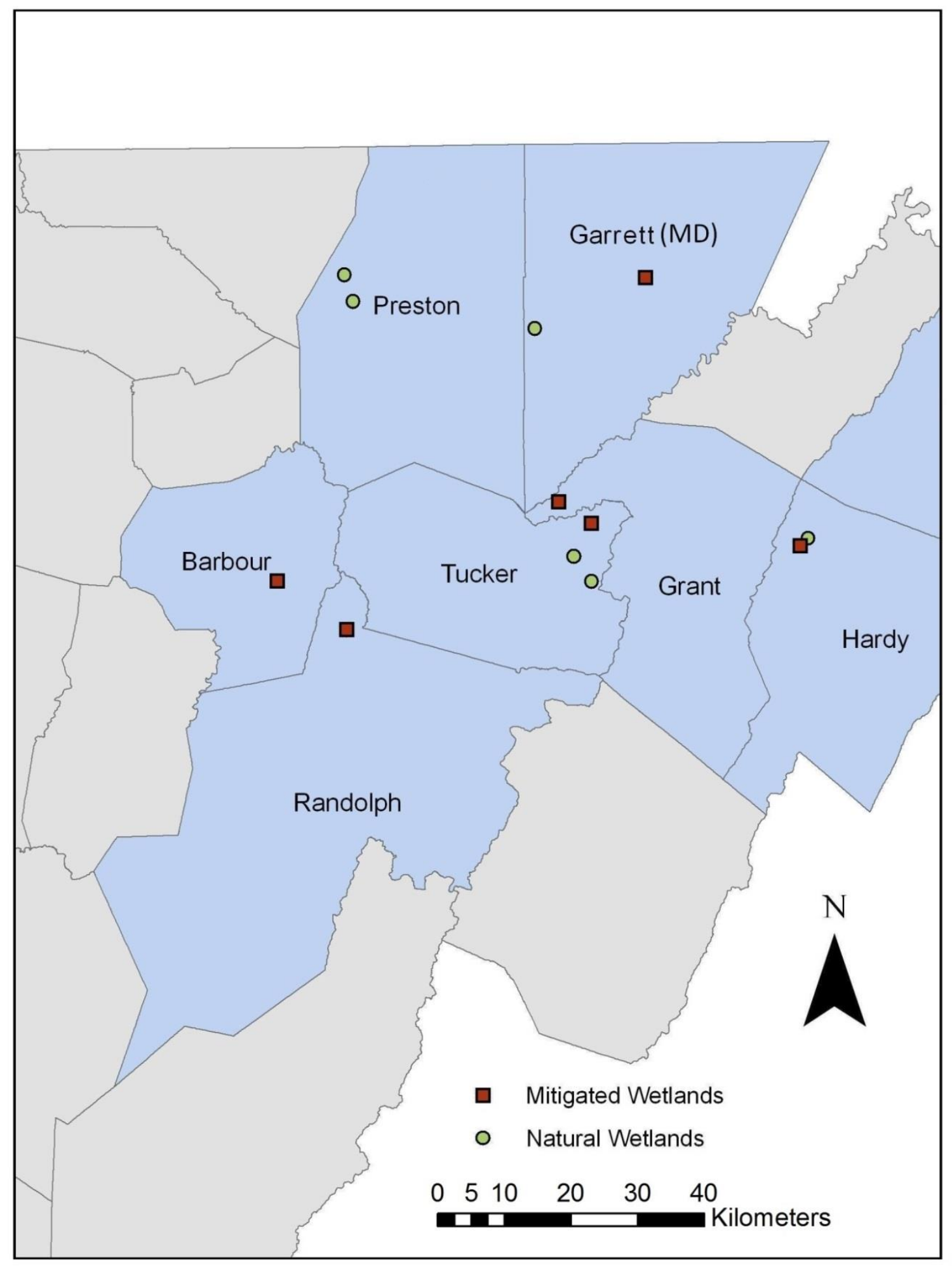

Figure 1. Locations of natural $(n=6)$ and created $(n=6)$ wetlands used to study red-spotted newt diet selection in the Central Appalachians. 


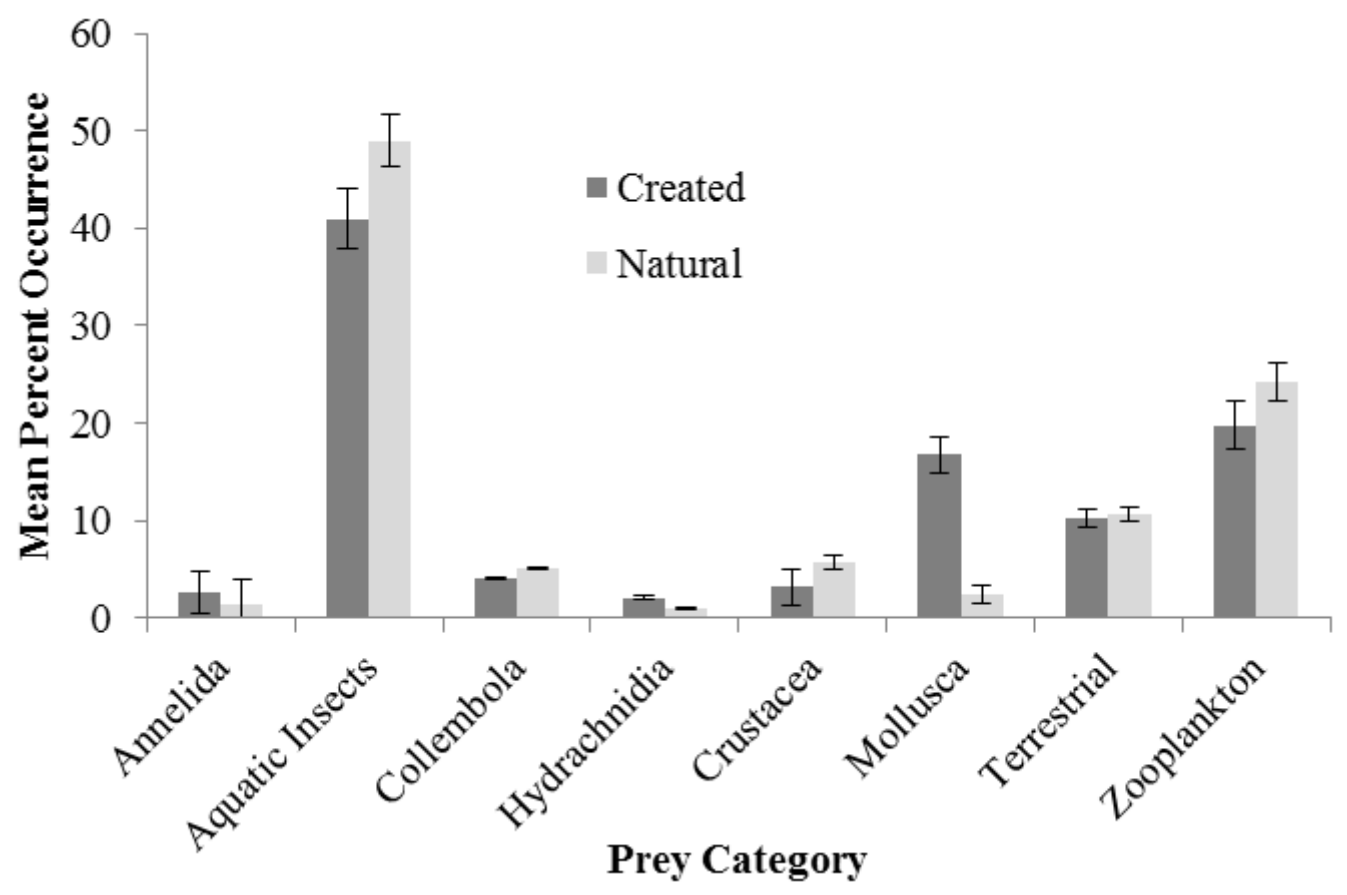

Figure 2. Mean percent occurrence ( $\pm 1 \mathrm{SE}$ ) by prey category in stomachs of red-spotted newts inhabiting created and natural wetlands of the Central Appalachians. 


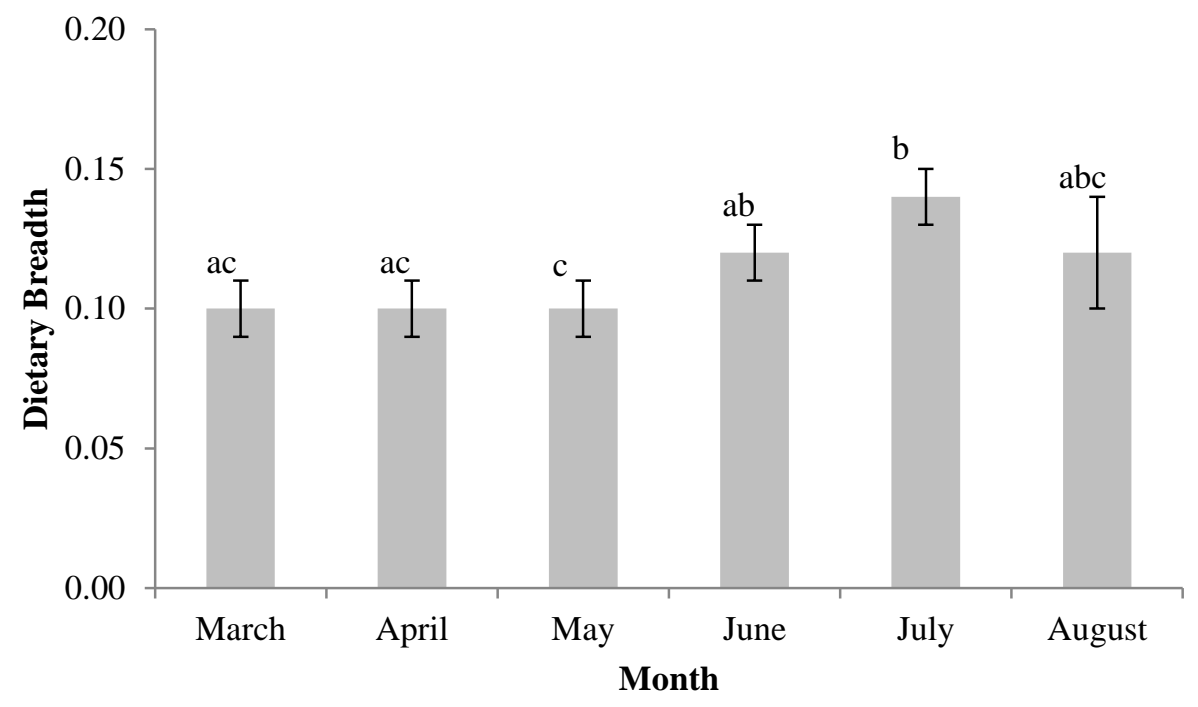

Figure 3. Mean monthly dietary breadth $( \pm 1 \mathrm{SE})$ of red-spotted newts inhabiting created and natural wetlands of the Central Appalachians during 2009 and 2010 (different letters indicate significant differences between months at $p=0.05$ ). 


\title{
CHAPTER V
}

\section{CREATED WETLANDS AS FUNCTIONALLY EQUIVALENT AMPHIBIAN HABITAT: SYNTHESIS AND APPLICATIONS}

\author{
Gabriel F. Strain \\ West Virginia University, Division of Forestry and Natural Resources, PO Box 6125, \\ Morgantown, WV 26506-6125
}

Written in the style of:

The Journal of Herpetology 


\title{
Created wetlands as functionally equivalent amphibian habitat: Synthesis and Applications
}

\author{
GABRIEL F. STRAIN
}

Division of Forestry and Natural Resources, West Virginia University, P.O. Box 6125, Morgantown, WV 26506-6125, USA

\section{Introduction}

Wetlands provide important ecosystem services, such as storage of excess water, assimilation of nutrients, and habitat for wildlife (Dahl and Johnson, 1991; Tiner, 2002; Balcombe et al., 2005a; Mitsch and Gosselink, 2007). Many amphibian species depend on wetlands and spend all or part of their life cycle in them because they offer excellent sources of food, protection, and breeding opportunities (Gibbons, 2003). In turn, amphibians provide an abundant and high energy food source for larger predators such as birds and mammals (Davic and Welsh, 2004).

However, more than $53 \%$ of the wetland area in the United States has been lost since the 1780s (Dahl, 1990) due to drainage, dredging, hydrologic alterations, and water pollution related to activities such as agriculture, development, and mining (Mitsch and Gosselink, 2007). This loss threatens the biodiversity of amphibians through habitat destruction and loss of connectivity 
(Semlitsch and Bodie, 1998). A policy of "no net loss" of wetlands in the United States has been established since the first Bush administration (Turner et al., 2001). Although avoidance of wetland impacts is preferred, compensatory mitigation, which is the replacement or compensation of wetland area and function when permitted damage to natural wetlands is unavoidable, is a major tool used to accomplish this goal (Zedler, 1996; Cole and Shafer, 2002). However, the success of wetland mitigation is equivocal because, although recent studies demonstrate that emergent and scrub-shrub wetlands have increased in area in the United States, losses outweigh gains in overall wetland area (Dahl, 2011), and evidence suggests that certain functions such as nutrient cycling are not being adequately mitigated (Hossler et al., 2011).

In most cases, the success of created wetlands is judged by examining parameters such as hydrology, vegetative cover, or the presence of wildlife; however, the structural similarity of a created wetland to a lost wetland does not necessarily mean that the mitigated wetland functions properly (Campbell et al., 2002). In particular, call surveys for amphibians may not be adequate to determine that created wetlands fulfill the functions necessary to maintain amphibian populations. Adults may call and breed at wetlands, but mortality of larvae and metamorphs may result in reproductive failure (Petranka et al., 2003a). Therefore, assessment of amphibians inhabiting created wetlands is important to facilitate determination of the adequacy of created wetlands as functional replacements of natural wetlands. The primary objectives of this study were to investigate and compare the reproductive success, temporal calling patterns, and diet composition of amphibians inhabiting created versus natural wetlands.

I selected 6 created $(\overline{\mathrm{x}}=6.1$ ha, $\mathrm{SE}=1.4)$ and 6 natural $(\overline{\mathrm{x}}=2.5 \mathrm{ha}, \mathrm{SE}=0.6)$ wetlands for study. The West Virginia Division of Highways constructed the majority of created wetlands 
used in this study to offset losses to natural wetlands during the construction of 2 major highways (Gingerich and Anderson, 2011). In the construction of these created wetlands, excavated wetland basins were lined with clay and topsoil, and seeded and planted with herbaceous and woody plant species, respectively. I paired each created wetland with a natural wetland similar in elevation (created $\bar{x}=683.5 \mathrm{~m}, \mathrm{SE}=105.8$; natural $\overline{\mathrm{x}}=667.2 \mathrm{~m}, \mathrm{SE}=109.8$ ) and underlying geology, factors that are thought to affect wetland habitat (Diehl and Behling, 1982; Weakley and Schafale, 1994; Halsey, 1997; Bledsoe and Shear, 2000; Francl et al., 2004). The majority of created wetlands in West Virginia and other states tend to be dominated by open water compared to natural wetlands (Cole and Brooks, 2000; Balcombe et al., 2005b). Historic beaver (Castor canadensis)-created wetlands also tend to be dominated by open water (Naiman et al., 1988) and thus may approximate the conditions of created wetlands as amphibian habitat more so than other wetland types in the state. I thus selected beaver ponds as the natural wetlands.

\section{Reproductive Success}

Measurements such as vegetative cover and presence of wildlife may not provide sufficient evidence that created wetlands are functioning properly and thus examining the ecology of wetland biota such as that of amphibians may be a more useful surrogate for function. In order to accomplish that goal, this portion of the study (Chapter 2) focused on comparing the abundance of amphibian metamorphs and survival and growth of larval amphibians in created wetlands relative to natural wetlands. 
Evaluating the abundance of metamorphs in wetlands is not straightforward because amphibians are likely detected imperfectly (Schmidt, 2003). Imperfect detection can severely bias estimates of abundance, trends, or comparisons between experimental or observational treatments, because failure to detect species that are present results in false absences (Yoccoz et al., 2001; MacKenzie et al., 2002). This problem can be demonstrated with the formula

$$
E(C)=N p,
$$

where $E(C)$ is the expected value of a count of individuals, $N$ is the true number of individuals, and $p$ is the detection probability (Nichols, 1992). The estimate of $N$ is a function of both the count $C$ and the detection probability $p$. Comparisons between counts taken at multiple times or sites $\left(C_{1} / C_{2}\right)$ are only reliable if $p$ is constant between sampling times or sites (Yoccoz et al., 2001). In reality the assumption of constant detection probabilities is rarely if ever met (Yoccoz et al., 2001; MacKenzie and Kendall, 2002). Detection probability may be affected by multiple factors such as weather conditions and sampling techniques. To make reliable inferences, it is important to partition variation in detection from variation in the variable of interest, such as abundance. Thus, I used occupancy modeling to account for variable detection in the comparison of the abundance of amphibian metamorphs in created wetlands relative to natural wetlands.

Because most of the wetlands in my study were large and heterogeneous with no welldefined "edge," the common practice of surrounding wetlands with drift fences to capture amphibians was not logistically feasible. Therefore, I conducted amphibian sampling via aquatic funnel traps (Micacchion, 2002) and dipnet sweeps. I randomly chose 15 positions along the perimeter of each wetland, and placed 1 trap at each of these 15 positions. 
Traps were positioned so that a portion of the trap was not submerged, allowing captured adult amphibians to breathe. Funnel traps were opened once every month, and they remained open for 24 hours to maximize captures and to minimize mortality (Micacchion, 2002). I returned the following day at approximately the same time to check traps, at which time I also took a random $1 \mathrm{~m}^{2}$ dipnet sample near each trap (Micacchion, 2002). I sampled during the spring and summer of 2009 and 2010. Metamorphs encountered in each trap and dipnet sweep were identified to species, and Gosner (1960) stage, which assigns a number based on hind limb development and other ontogenetic changes, was recorded. I designated as metamorphs all individuals at stage 42 or beyond (eruption of forelimbs).

To compare survival and growth rate of amphibian larvae between created and natural wetlands, I collected a sample of 180 larval green frogs (Lithobates clamitans) and raised half of them in laboratory aquaria containing water from created wetlands and half in aquaria containing water from natural wetlands. All individuals had hatched the previous summer and overwintered in the wetland and were of similar Gosner (1960) stage (30-33). I transported tadpoles to the laboratory where they were housed in 36 aquaria ( $\sim 3$ L plastic containers), with 5 larvae per aquarium. Because there were 6 wetlands of each type used in this study and 3 aquaria per wetland, each treatment had 18 replicates. I randomly allocated individual tadpoles to aquaria containing water from either created or natural wetlands and for 84 weeks, I counted the number still alive and measured the mass of tadpoles weekly during water changes. The wet mass of all tadpoles in an aquarium was averaged to provide a mean mass of tadpoles over time. I used a generalized linear mixed model to model the number of tadpoles surviving as a function of wetland type. To compare the mass of tadpoles, I fitted a linear mixed model weighted by the 
number of tadpoles (which gradually declined throughout the study) used to calculate the mean mass of tadpoles in each aquarium.

I encountered metamorphs of 7 amphibian species, but only 2 species were captured frequently enough for analyses: green frog (Lithobates clamitans) and spring peeper (Pseudaris crucifer). The mean abundance of spring peeper metamorphs decreased by an estimated $86 \%$ $(95 \%$ C.I. $=62 \%, 95 \%)$ from 2009 to 2010 , but abundance was similar between created and natural wetlands. The abundance of green frog metamorphs was similar between created and natural wetlands, but increased with habitat complexity. Water temperature and month significantly affected detection of both species, but in opposite directions: detection probability increased with water temperature and decreased over time.

Survival of laboratory tadpoles did not depend on wetland type. Tadpoles raised in water from created and natural wetlands had a $0.25(\mathrm{SE}=0.07)$ and $0.24(\mathrm{SE}=0.07)$ mean probability of survival, respectively. Growth rates of tadpoles did not depend on wetland type, and the mean mass of tadpoles was $1.98 \mathrm{~g}(\mathrm{SE}=0.25)$ in created wetlands and $2.01 \mathrm{~g}(\mathrm{SE}=0.24)$ in natural wetlands.

\section{Call Phenology}

Balcombe et al. $(2005 a ; 2005 b ; 2005 c)$ used anuran call survey data and other wildlife parameters as surrogates for function. They found that created wetlands in West Virginia supported the same 7 species of amphibians that reference sites did, and that Wisconsin call index values and relative abundance of calling anurans were higher in mitigated wetlands for some species. Call surveys are widely used because they provide species lists and 
approximations of breeding activity (Zimmerman, 1994; Weir et al., 2005), and can be performed quickly and easily, often with the help of volunteers (Genet and Sargent, 2003). However, standard call surveys may not detect some species because the surveys are performed for a limited period of time and easily disturbed species may not call during the survey (Bridges and Dorcas, 2000). Therefore, alternative survey methods such as broadcasting advertisement calls and increasing the length of surveys may yield improved results. Additionally, inferences based on raw counts of species or call indices may be biased unless detection probability is taken into account (MacKenzie et al., 2006). Thus, the specific objectives of this portion of the study (Chapter 3) were to account for variable detection in the comparison of the use of created and natural wetlands by breeding anurans and at the same time examine factors affecting the detection of encountered species. The secondary objective was to compare the efficacy of conducting 5-minute manual call surveys, 10-minute manual call surveys, and broadcast calls.

To increase the sample size for this portion of the study, I included an additional 6 created and 6 natural wetlands, and omitted the pairing of wetlands. Nocturnal call surveys were performed at each site once every month from March through August of 2009 and 2010. Observers performed a 5-minute call survey, 10-minute call survey, and a broadcast call survey (1 for each species) in a randomized sequence near the center of each wetland. Broadcast calls consisted of broadcasting the call of each species for 1 minute via an mp3 player attached to speakers followed by a 3-minute listening period (Mannan, 2008). Observers identified all calling anurans to species and recorded air temperature, relative humidity, wind speed, water temperature, and percent cloud cover. I used an occupancy modeling framework to estimate and compare the occupancy of individual anuran species as well as overall species richness in created 
and natural wetlands and examine the effect of environmental variables on detection of each species encountered.

A total of 11 anuran species were detected, 11 species in created wetlands and 9 in natural wetlands; analyses were performed for the 8 species for which I obtained sufficient data. The occupancy and detection of each species was similar between created and natural wetlands. Year had no effect on the occupancy of anurans, with the exception of wood frogs (Lithobates sylvaticus); the occupancy of wood frogs significantly increased from 2009 to 2010. The detection probability of green frogs (Lithobates clamitans) was higher during broadcast surveys $(p=0.87,95 \%$ C.I. $=0.81,0.91)$ than during 10 -minute $(p=0.84,95 \%$ C.I. $=0.78,0.89)$ and 5minute surveys $(p=0.76,95 \%$ C.I. $=0.69,0.82)$; however, substantial overlap in $95 \%$ confidence intervals was observed. The detection probabilities of all other species were similar across survey methods.

Julian day and wind speed significantly affected detection of American toads (Anaxyrus americanus), but in opposite directions: detection probability increased with wind speed and decreased over time. Detection probability of Cope's gray treefrogs (Hyla chrysoscelis) increased with air temperature and cloud cover, but decreased with wind speed and Julian day. Detection probability of gray treefrogs (Hyla versicolor) increased with air temperature, but decreased with wind speed and Julian day. Detection probability of green frogs increased with water temperature, wind speed, and Julian day. Increasing wind speed and Julian day increased the detection of wood frogs. Detection probability of spring peepers increased with air temperature, cloud cover, but decreased with wind speed and Julian day. The detection probabilities of American bullfrog (Lithobates catesbeianus) and pickerel frog (Lithobates 
palustris) were not affected by any of our measured variables. Mean anuran species richness was similar between created and natural wetlands and between the 2009 and 2010 sampling seasons. Air temperature, relative humidity, and Julian day significantly affected detection of calling anurans, but in different directions: detection probability increased with air temperature and relative humidity and decreased over time.

\section{Diet Composition}

Vegetation structure, hydroperiod, and the occurrence of food resources and predators influence the habitat quality of wetlands for wildlife (Anderson and Gutzwiller, 1994). In turn, habitat quality affects life history aspects of wildlife populations such as reproduction, survival, recruitment, growth, and diet. Examination of these aspects can assist in determining whether or not created wetlands are fulfilling this vital function. Balcombe et al. (2005d) found that created and natural wetlands in West Virginia supported similar macroinvertebrate assemblages and thus concluded that the created wetlands they examined provided adequate resources for wildlife such as waterfowl and anurans. The next step was to test this conclusion by examining the diet of amphibians inhabiting both created and natural wetlands.

Amphibians are predatory wetland inhabitants that can have considerable impact on the structure of wetland invertebrate communities (Smith et al., 2004), but little work has been done to examine the diet composition of amphibians in created wetlands. Red-spotted newts (Notophthalmus viridescens viridescens Rafinesque) have one of the largest ranges of any amphibian in the United States (Hunsinger and Lannoo, 2005), are common in many types of wetlands throughout the Central Appalachian region (Gates and Thompson, 1982), and are often 
the most significant predator in wetland systems (Burton, 1977). For these reasons, $N . v$. viridescens makes an ideal study organism. The specific objectives of this portion of the study (Chapter 4) were to compare the diet composition and the use and selection of invertebrate prey items by adult $N . v$. viridescens between created and natural wetlands.

Newts were collected with funnel traps (Micacchion, 2002) and dipnet sweeps. I randomly placed 15 traps along the perimeter of each wetland. Traps were opened once every month from March through August in 2009 and 2010. Traps remained open approximately 24 hours to maximize captures and to minimize mortality (Micacchion, 2002). I took a standardized dipnet sweep of approximately $1 \mathrm{~m}^{2}$ at a randomly selected spot within a $5 \mathrm{~m}$ radius of each trap as traps were checked. Immediately upon removal from funnel traps or capture with dipnets, I flushed each newt's stomach by using a small syringe to force water into the stomach, which forced out the stomach contents (Legler and Sullivan, 1979; Griffiths, 1986). I sexed newts (Petranka, 1998) and released them at the site of capture. Invertebrates were sampled using 3 randomly selected $1 \mathrm{~m}^{2}$ quadrats per individual collected within $5 \mathrm{~m}$ and $\leq 30 \mathrm{~min}$ of newt collection (Anderson et al., 2000). I swept the water surface, column, and benthos within each quadrat. I identified stomach content and dipnet samples to the lowest practical taxonomic level. I calculated the dietary breadth (DB, Anderson et al., 1999) of each newt, and fit a factor effects analysis of variance (ANOVA) model to test the effect of wetland type (created or natural), month (March through August), and sex (male or female) on DB; I constructed a contrast to examine the effect of season (spring or summer) on dietary breadth. I used compositional analysis to determine if amphibians were consuming invertebrates in proportion to availability between wetland types, month, season, and sex, and followed the methodology of 
Aebischer et al. (1993). I fit multiple univariate factor effects ANOVA models for the 28 different responses (28 unique pairings of eight prey categories). I included wetland type, month, and sex as factors; I constructed a contrast to examine the effect of season. I compared the differences of level means for each factor using t-tests.

I performed gastric lavage on 149 N. v. viridescens; 61 newts (40 males and 21 females) from created wetlands $(\overline{\mathrm{x}}=10, \mathrm{SE}=4.6$, range $=0-45)$, and 88 newts (66 males and 22 females) from natural wetlands $(\overline{\mathrm{x}}=15, \mathrm{SE}=6.1$, range $=0-31)$. Invertebrate data were pooled into 8 broad categories for analysis: Annelida, aquatic Insecta, Collembola, Hydrachnidia, macrocrustacea, Mollusca, terrestrial invertebrates, and zooplankton. Mean dietary breadth of newts inhabiting created wetlands $(0.12, \mathrm{SE}=0.01)$, was similar to that of natural wetlands $(0.11, \mathrm{SE}=0.01)$, and was similar between male $(\overline{\mathrm{x}}=0.12, \mathrm{SE}=0.01)$ and female $(\overline{\mathrm{x}}=0.11, \mathrm{SE}$ $=0.01$ ) newts. Although similarly low (ranging from 0.10 to 0.14 ), the dietary breadth of newts was significantly higher in July than in March, April, and May, and was also higher in June compared to May. Diet selection of $N$. v. viridescens was not random; newts did not select prey in proportion to availability. For all newts, the compositional analysis ranked prey categories (from most preferred to least preferred) in the order: zooplankton $>$ aquatic Insecta $>$ Collembola $>$ terrestrial invertebrates $>$ macrocrustacea $>$ Mollusca $>$ Hydrachnidia $>$ Annelida. In general, the selection of prey by $N . v$. viridescens was affected mostly by variation in month, only minimally by the type of wetland and season, and was similar between males and females. 


\section{Synthesis}

The reproductive success of spring peepers and green frogs inhabiting the created wetlands in this study was similar to that of natural wetlands; variation in production of metamorphs was driven by other factors (i.e., habitat complexity and time). Although more longterm data would be required to determine population trajectories, this study demonstrates that over the 2 seasons of my study created wetlands functioned similarly to natural wetlands with respect to amphibian metamorph production, which suggests that these created wetlands may provide comparable habitat to natural wetlands, thus ensuring successful reproduction by amphibians. Occupancy estimation demonstrated that the created and natural wetlands that I monitored did not differ with respect to occupancy (e.g., the proportion of sites occupied) of anurans. This provides evidence that amphibians are colonizing and using created wetlands as breeding habitat throughout the Central Appalachian region. Diet composition and selection of prey by $N . v$. viridescens was overall similar between created and natural wetlands. Studies indicate that colonization of created wetlands by invertebrates is relatively rapid (Stanczak and Keiper, 2004), thus providing prey for colonizing amphibians and other predators of invertebrates. The mean age of the created wetlands at the initiation of the present study was 15 years, and it appears that adequate time had passed for the created wetlands in my study to develop invertebrate communities. The results of this study suggest that the function of providing an adequate prey base for a generalist wetland predator is being fulfilled for the wetlands that I examined.

In general, some created wetlands outperform natural wetlands with respect to amphibians (e.g., Petranka et al., 2003b; Balcombe et al., 2005a; Korfel et al., 2010), whereas 
others fall short of functional equivalency (e.g., Lehtinen and Galatowitsch, 2001; DiMauro and Hunter, 2002; Ruiz et al., 2010). This may be partially due to the high variability that wetlands exhibit (Mitsch and Gosselink, 2007). Unlike stream systems, which have a regional but predictable pattern of flora and fauna (Vannote et al., 1980), wetlands exhibit a wide range of variation in characteristics including hydrology (Shaffer et al., 1999), vegetation (Byers et al., 2007), microbial activity (Groffman et al., 1996), and soil nutrients (Chambers and Pederson, 2006). Wetland characteristics, such as water temperature (Oseen and Wassersug, 2002), forest canopy (Skelly et al., 2002), and hydroperiod (Semlitsch, 1987), exert known effects on amphibians inhabiting wetlands. Many wetlands are unique due to this remarkable variation, and making generalizations about wetlands is thus difficult.

Not only are wetlands highly variable, but amphibian population dynamics are also largely stochastic. Year-to-year variation in parameters affecting reproductive success, such as reproductive effort, number of eggs deposited, and egg and larval mortality, can be quite high (Richter et al., 2003). Breeding amphibians may be completely absent from wetlands for several years (Trenham et al., 2003). Demographic stochasticity coupled with the physico-chemical and hydrological variation present in wetlands results in variable amphibian dynamics in both created and natural wetlands, the trends of which are difficult to discern from 2 years of data. Although more work and more long-term data are needed, the results of this study provide evidence that created wetlands in the Appalachian region are functionally equivalent to natural wetlands with respect to providing amphibian habitat.

A potential limitation of this study is the use of historic beaver ponds as natural wetlands. Although the proportion of wetlands in the United States comprised by beaver ponds is unknown 
(Butler and Malanson 2005), they do not comprise a dominant proportion due to the extirpation of beavers in the $19^{\text {th }}$ century. In West Virginia, the proportion of ponded wetlands is approximately 17\% (Tiner and Finn 1986), a smaller proportion of which are beaver ponds. I selected beaver ponds to control for the effects of variation in hydrology, but if ponded wetlands are not typical of the Central Appalachian region my results may overestimate the similarity of created wetlands to natural wetlands. Similarly, inferences made in this dissertation about the similarity of created wetlands to natural wetlands is based on data obtained from relatively generalist amphibians such as American Toads (Green 2005) spring peepers (Butterfield et al. 2005), green frogs (Pauley and Lannoo 2005), and red-spotted newts (Hunsinger and Lannoo 2005). My dissertation necessarily focused on these species because higher captures of these species enabled higher statistical power; captures of many other species were too low for analyses. However, I caution the reader to consider that similarity between created and natural wetlands that I found for these generalist species may not hold for species with more specific habitat requirements such as four-toed salamanders and spotted salamanders (Petranka 1998). More work is required to determine how well created wetlands support populations of specialist amphibians.

\section{Management Applications}

This study demonstrates that created wetlands in the Appalachian region function as habitat for amphibians. To increase the functionality of created wetlands and provide breeding and foraging habitat for all local amphibians, wetlands should be designed to intentionally incorporate habitat features such as complex edges (Petranka et al., 2007), shallow zones (Porej 
and Hetherington, 2005), variable hydroperiod (Pechmann et al., 2001), heterogeneous surrounding landscape (Lesbarreres et al., 2010), and should be placed near other wetland habitat (Shulse et al., 2010). The majority of wetlands used in this study were comprised primarily of open water cells. Constructing wetlands as open water bodies may provide suitable habitat for permanent-water species such as American bullfrogs and green frogs, but may prevent other taxa such as salamanders and hylid frogs from persisting due to the presence of fish (Shulse et al., 2010). Wetland construction that narrowly focuses on ensuring wetland hydrology by creating open water ponds may neglect the vegetated portion and surrounding uplands of created wetlands (Zedler, 1996), habitat components which are vital to amphibians (Lamoureux and Madison, 1999; Lehtinen et al., 1999; Pope et al., 2000; Gibbons, 2003). Future wetland creation must also necessarily account for climate change (e.g., by excavation of deep areas to ensure wetlands hold water long enough for larvae to metamorphose), as evidence is mounting that these changes affect the breeding phenology of adults (Daszak et al., 2005; Todd et al., 2011), with consequences for future generations (Orizaola et al., 2012). Lastly, long-term monitoring is crucial to ensure that created wetlands are resilient to perturbations and continue to offer quality habitat for wildlife.

\section{Future Research Needs}

Habitat generalists or species insensitive to disturbance may readily and successfully breed in created wetlands, whereas species with specific habitat requirements, such as wood frogs and spotted salamanders, may struggle due to pressure from predatory fish or other unsuitable habitat characteristics. Created wetlands may exhibit decreased or no production of 
metamorphs and therefore may act as ecological traps for these specialist amphibian species (DiMauro and Hunter 2002). Therefore, assessment of the adequacy of created wetlands to support specialist species is warranted. Future research question: How well do created wetlands support populations of amphibians with specific habitat requirements?

Demographic variability may be influenced by weather or other factors with a lag of several years (Trenham et al. 2003); hence, monitoring wetlands for several years is ideal for accurately gauging functional equivalency (Pechmann et al. 2001). Future research improvement: Monitor created and natural wetlands for several (5 or more) years to accumulate long-term data in order to determine the presence of trends with respect to amphibian populations.

As detection probabilities of metamorphs in my study were low, a significant increase in sampling effort via number of traps deployed at each wetland and frequency of visits to wetlands may be required to increase detection probabilities, especially for species that transform quickly. Future research improvement: Concentrate effort on increasing number of traps and site visits to increase detection probabilities and strengthen inferences.

Landscape parameters, such as proximity to other aquatic habitat, nearby forest, road density, and urbanization affect the suitability of created and restored wetlands as amphibian habitat (Stevens et al. 2002, Shulse et al. 2010, Guzy et al. 2012). Examining parameters such as distance to nearest road (Kirlin et al. 2006) may be especially useful in a wetland mitigation context because wetlands are often created adjacent to or near anthropogenically disturbed areas (National Research Council 2001). Future research question: How does landscape context affect the suitability of created wetlands as amphibian habitat? 
As generalist predators (Hunsinger and Lannoo 2005; Petranka 1998), adult red-spotted newts most likely have a diet similar to other generalist aquatic amphibians inhabiting wetlands. However, some amphibian species may be specialized predators (Anderson et al. 1999; Macale et al. 2008), and assessing the adequacy of created wetlands to support those species is important. Future research question: Is the diet composition and prey selection similar between specialized amphibian predators inhabiting created and natural wetlands?

\section{Literature Cited}

Aebischer, N.J, P.A. Robertson, and R.E. Kenward. 1993. Compositional analysis of habitat use from animal radio-tracking data. Ecology 74:1313-1325.

Anderson, A.M, D.A. Haukos, and J.T. Anderson. 1999. Diet composition of three anurans from the playa wetlands of northwest Texas. Copeia 1999:515-520.

Anderson, J.T., L.M. Smith, and D.A. Haukos. 2000. Food selection and feather molt by nonbreeding American green-winged teal in Texas playas. Journal of Wildlife Management 64:222-230.

Anderson, S.H., and K.J. Gutzwiller. 1994. Habitat evaluation methods. Pages 592-606 in Bookhout T.A. (ed). Research and management techniques for wildlife and habitats, 5th ed. Wildlife Society, Bethesda, MD, USA.

Balcombe, C.K., J.T. Anderson, R.H. Fortney, and W.S. Kordek. 2005a. Wildlife use of mitigation and reference wetlands in West Virginia. Ecological Engineering 25:85-99.

Balcombe, C.K., J.T. Anderson, R.H. Fortney, J.S. Rentch, W.N. Grafton, and W.S. Kordek. 
2005b. A comparison of plant communities in mitigation and reference wetlands in the mid-Appalachians. Wetlands 25:130-142.

Balcombe, C.K., J.T. Anderson, R.H. Fortney, and W.S. Kordek. 2005c. Vegetation, invertebrate, and wildlife community rankings and habitat analysis of mitigation wetlands in West Virginia. Wetlands Ecology and Management 13:517-530.

Balcombe, C.K., J.T. Anderson, R.H. Fortney, and W.S. Kordek. 2005d. Aquatic macroinvertebrate assemblages in mitigated and natural wetlands. Hydrobiologia 541:175-188.

Bledsoe, B.P., and T.H. Shear. 2000. Vegetation along hydrologic and edaphic gradients in a North Carolina Coastal Plain creek bottom and implications for restoration. Wetlands 20:126-147.

Bridges, A.S., and M.E. Dorcas. 2000. Temporal variation in anuran calling behavior: implications for surveys and monitoring programs. Copeia 2000:587-592.

Burton, T.M. 1977. Population estimates, feeding habits and nutrient and energy relationships of Notophthalmus v. viridescens, in Mirror Lake, New Hampshire. Copeia 1977:139-143.

Butler, D.R, and G.P. Malanson. 2005. The geomorphic influences of beaver dams and failures of beaver dams. Geomorphology 71:48-60.

Butterfield, P.M., M.J. Lannoo, and P. Nanjappa. 2005. Pseudacris crucifer. Pages 472-474 in Lannoo, M. (ed). Amphibian declines. University of California Press, Berkeley, MD, USA.

Byers, E.A., J.P. Vanderhorst, and B.P. Streets. 2007. Classification and conservation 
assessment of high elevation wetlands communities in the Allegheny Mountains of West Virginia. West Virginia Natural Heritage Program, West Virginia Division of Natural Resources, Elkins, WV, USA.

Campbell, D.A., C.A. Cole, and R.P. Brooks. 2002. A comparison of created and natural wetlands in Pennsylvania, USA. Wetlands Ecology and Management 10:41-49.

Chambers, R.M., and K.A. Pederson. 2006. Variation in soil phosphorus, sulfur, and iron pools among south Florida wetlands. Hydrobiologia 569:63-70.

Cole, C.A., and R.P. Brooks. 2000. A comparison of the hydrologic characteristics of natural and created mainstem floodplain wetlands in Pennsylvania. Ecological Engineering 14:221-231.

Cole, C.A., and D. Shafer. 2002. Section 404 wetland mitigation and permit success criteria in Pennsylvania, USA, 1986-1999. Environmental Management 30:508-515.

Dahl, T.E. 2011. Status and trends of wetlands in the conterminous United States 2004 to 2009. U.S. Department of the Interior, Fish and Wildlife Service, Washington, D.C.

Dahl, T.E. 1990. Wetlands losses in the United States 1780's to 1980's. U.S. Department of the Interior, Fish and Wildlife Service, Washington, D.C., USA.

Dahl, T.E., and C.E. Johnson. 1991. Status and trends of wetlands in the conterminous United States, mid-1970's to mid-1980's. U.S. Department of the Interior, Fish and Wildlife Service, Washington, D.C.

Daszak, P., D.E. Scott, A.M. Kilpatrick, C. Faggioni, J.W. Gibbons, and D. Porter. 2005. Amphibian population declines at Savannah River Site are linked to climate, not chytridiomycosis. Ecology 86:3232-3237. 
Davic, R.D., and H.H. Welsh, Jr. 2004. On the ecological role of salamanders. Annual Review of Ecology, Evolution, and Systematics 35:405-434.

Diehl, J.W., and R.E. Behling. 1982. Geologic factors affecting formation and presence of wetlands in the north central section of the Appalachian Plateaus Province of West Virginia. Pages 3-9 in B.R. McDonald, editor. Proceedings of the symposium on wetlands of the unglaciated Appalachian region. West Virginia University, Morgantown, USA.

DiMauro, D., and M.L. Hunter. 2002. Reproduction of amphibians in natural and anthropogenic temporary pools in managed forests. Forest Science 48:397-406.

Francl, K.E., W.M. Ford, and S.B. Castleberry. 2004. Characterization of high elevation central Appalachian wetlands. Research Paper NE-725. U.S. Department of Agriculture, Forest Service, Northeastern Research Station, Newtown Square, Pennsylvania, USA.

Gates, J.E., and E.L. Thompson. 1982. Small pool habitat selection by red-spotted newts in western Maryland. Journal of Herpetology 16:7-15.

Genet, K.S., and L.G. Sargent. 2003. Evaluation of methods and data quality from a volunteer-based amphibian call survey. Wildlife Society Bulletin 31:703-714.

Gibbons, J.W. 2003. Terrestrial habitat: a vital component for herpetofauna of isolated wetlands. Wetlands 23:630-635.

Gingerich, R.T., and J.T. Anderson. 2011. Decomposition trends of five plant litter types in mitigated and reference wetlands in West Virginia, USA. Wetlands 31:653-662.

Gosner, K.L. 1960. A simplified table for staging anuran embryos and larvae with notes on identification. Herpetologica 16:183-190. 
Green, D.M. 2005. Bufo americanus. Pages 386-390 in Lannoo, M. (ed). Amphibian declines. University of California Press, Berkeley, MD, USA.

Griffiths, R.A. 1986. Feeding niche overlap and food selection in smooth and palmate newts, Triturus vulgaris and T. Helveticus, at a pond in mid-Wales. Journal of Animal Ecology 55:201-214.

Groffman, P.M., G.C. Hanson, E. Kiviat, and G. Stevens. 1996. Variation in microbial biomass and activity in four different wetland types. Soil Science Society of America Journal 60:622-629.

Guzy, J.C., E.D. McCoy, A.C. Deyle, S.M. Gonzalez, N. Halstead, and H.R. Mushinsky. 2012. Urbanization interferes with the use of amphibians as indicators of ecological integrity of wetlands. Journal of Applied Ecology 49:941-952.

Halsey, L. 1997. Climatic and physiographic controls on wetland type and distribution in Manitoba, Canada. Wetlands 17:243-262.

Hossler, K., V. Bouchard, M.S. Fennessy, S.D. Frey, E. Anemaet, and E. Herbert. 2011. Nonet-loss not met for nutrient function in freshwater marshes: recommendations for wetland mitigation policies. Ecosphere 2:1-36.

Hunsinger, T.W., and M. Lannoo. 2005. Notophthalmus viridescens. Pages 889-894 in Lannoo, M. (ed). Amphibian declines. University of California Press, Berkeley, MD, USA.

Kirlin, M.S., M.M. Gooch, S.J. Price, and M.E. Dorcas. 2006. Predictors of winter anuran calling activity in the North Carolina Piedmont. Journal of the North Carolina Academy of Science 122:10-18.

Korfel, C.A, W.J. Mitsch, T.E. Hetheringon, and J.J. Mack. 2010. Hydrology, physiochemistry, 
and amphibians in natural and created vernal pool wetlands. Restoration Ecology 18:843854.

Lamoureux, V.S., and D.M. Madison. 1999. Overwintering habitats of radio-implanted green frogs, Rana clamitans. Journal of Herpetology 33:430-435.

Legler, J.M., and L.J. Sullivan. 1979. The application of stomach-flushing to lizards and anurans. Herpetologica 35:107-110.

Lehtinen, R.M., S.M. Galatowitsch, and J.R. Tester. 1999. Consequences of habitat loss and fragmentation for wetland amphibian assemblages. Wetlands 19:1-12.

Lehtinen, R.M., and S.M. Galatowitsch. 2001. Colonization of restored wetlands by amphibians in Minnesota. American Midland Naturalist 145:388-396.

Lesbarreres, D., M.S. Fowler, A. Pagano, and T. Lode. 2010. Recovery of anuran community diversity following habitat replacement. Journal of Applied Ecology 47:148-156.

Macale, D., L. Vignoli, and G.M. Carpaneto. 2008. Food selection strategy during the reproductive period in three syntopic hylid species from a subtropical wetland of northeast Argentina. Journal of Herpetology 18:49-58.

MacKenzie, D.I., and W.L. Kendall. 2002. How should detection probability be incorporated into estimates of relative abundance? Ecology 83:2387-2393.

MacKenzie, D.I., J.D. Nichols, G.B. Lachman, S. Droege, J.A. Royle, and C.A. Langtimm. 2002. Estimating site occupancy when detection probabilities are less than one. Ecology $83: 2248-2255$.

MacKenzie, D.I., J.D. Nichols, J.A. Royle, K.H. Pollock, L.L. Bailey, and J.E. Hines. 2006. 
Occupancy estimation and modeling: inferring patterns and dynamics of species occurrence. Academic Press, Burlington, MA, USA.

Mannan, R.N. 2008. An assessment of survey methodology, calling activity, and habitat associations of wood frogs (Rana sylvatica) and boreal chorus frogs (Pseudacris maculata) in a tundra biome. Thesis, Texas Tech University, Lubbock, TX, USA.

Micacchion, M. 2002. Amphibian index of biotic integrity (AmphIBI) for wetlands. Final report to U.S. EPA Grant No. CD985875-01. Ohio Environmental Protection Agency. Wetland Ecology Group, Division of Surface Water, Columbus, USA.

Mitsch, W.J., and J.G. Gosselink. 2007. Wetlands. $4^{\text {th }}$ edition. Wiley and Sons, Hoboken, New Jersey, USA.

Naiman, R.J., C.A. Johnston, and J.C. Kelley. 1988. Alteration of North American streams by beaver. BioScience 38:753-762.

National Research Council. 2001. Compensating for wetland losses under the Clean Water Act. National Academy Press, Washington D.C., USA.

Nichols, J.D. 1992. Capture-recapture models: using marked animals to study population dynamics. BioScience 42:92-102.

Orizaola, G., E. Dahl, A.G. Nicieza, and A. Laurila. 2012. Larval life history and anti-predator strategies are affected by breeding phenology in an amphibian. Oecologia 171:873-881.

Oseen, K.L., and R.J. Wassersug. 2002. Environmental factors influencing calling in sympatric anurans. Oecologia 133:616-625.

Pauley, T.K., and M. Lannoo. 2005. Rana clamitans. Pages 549-552 in Lannoo, M. (ed). Amphibian declines. University of California Press, Berkeley, MD, USA. 
Pechmann, J.H.K., R.A. Estes, D.E. Scott, and J.W. Gibbons. 2001. Amphibian colonization and use of ponds created for trial mitigation of wetland loss. Wetlands 21:93-111.

Petranka, J.W. 1998. Salamanders of the United States and Canada. Smithsonian Institution Press, Washington, D.C., USA.

Petranka, J.W., E.M. Harp, C.T. Holbrook, and J.A. Hamel. 2007. Long-term persistence of amphibian populations in a restored wetland complex. Biological Conservation 138:371380.

Petranka, J.W., S.S. Murray, and C.A. Kennedy. 2003a. Responses of amphibians to restoration of a southern Appalachian wetland: perturbations confound post-restoration assessment. Wetlands 23:278-290.

Petranka, J.W., C.A. Kennedy, and S.S. Murray. 2003b. Response of amphibians to restoration of a southern Appalachian wetland: a long-term analysis of community dynamics. Wetlands 23:1030-1042.

Pope, S.E., L. Fahrig, and H.G. Merriam. 2000. Landscape complementation and metapopulation effects on leopard frog populations. Ecology 81:2498-2508.

Porej, D., and T.E. Hetherington. 2005. Designing wetlands for amphibians: the importance of predatory fish and shallow littoral zones in structuring of amphibian communities. Wetlands Ecology and Management 13:445-455.

Richter, S.C., J.E. Young, G.N. Johnson, and R.A. Seigel. 2003. Stochastic variation in reproductive success of a rare frog, Rana sevosa: implications for conservation and for monitoring amphibian populations. Biological Conservation 111:171-177.

Ruiz, A.M., J.C. Maerz, A.K. Davis, M. Kevinkeel, A.R. Ferreira, M.J. Conroy, L.A. Morris, and 
A.T. Fisk. 2010. Patterns of development and abnormalities among tadpoles in a constructed wetland receiving treated wastewater. Environmental Science and Technology 44:4862-4868.

Schmidt, B.R. 2003. Count data, detection probabilities, and the demography, dynamics, distribution, and decline of amphibians. Comptes Rendus Biologies 326:119-124.

Semlitsch, R.D. 1987. Relationship of pond drying to the reproductive success of the salamander Ambystoma talpoideum. Copeia 1987:61-69.

Semlitsch, R.D., and J.R. Bodie. 1998. Are small, isolated wetlands expendable? Conservation Biology 12:1129-1133.

Shaffer, P.W., M.E. Kentula, and S.E. Gwin. 1999. Characterization of wetland hydrology using hydrogeomorphic classification. Wetlands 19:490-504.

Shulse, C.D., R.D. Semlitsch, K.M. Trauth, and A.D. Williams. 2010. Influences of design and landscape placement parameters on amphibian abundance in constructed wetlands. Wetlands 30:915-928.

Skelly, D.K., L.K. Freidenburg, and J.M. Kiesecker. 2002. Forest canopy and the performance of larval amphibians. Ecology 83:983-992.

Smith, L.M., M.J. Gray, and A. Quarles. 2004. Diets of newly metamorphosed amphibians in west Texas playas. Southwestern Naturalist 49:257-263.

Stanczak, M., and J.B. Keiper. 2004. Benthic invertebrates in adjacent created and natural wetlands in northeastern Ohio, USA. Wetlands 24:212-218.

Stevens, C.E., A.W. Diamond, and T.S. Gabor. 2002. Anuran call surveys on small wetlands in Prince Edward Island, Canada restored by dredging of sediments. Wetlands 22:90-99. 
Tiner, R.W., and J.T. Finn. 1986. Status and recent trends of wetlands in five Mid-Atlantic states. U.S. Department of the Interior, Fish and Wildlife Service, Washington, D.C.

Tiner, R.W. 2002. In search of swampland. A wetlands sourcebook and field guide. Rutgers University Press, New Brunswick, NJ, USA.

Todd, B.D., D.E. Scott, J.H.K. Pechmann, and J.W. Gibbons. 2011. Climate change correlates with rapid delays and advancements in reproductive timing in an amphibian community. Proceedings of the Royal Society 278:2191-2197.

Trenham, P.C., W.D. Koenig, M.J. Mossman, S.L. Stark, and L.A. Jagger. 2003. Regional dynamics of wetland-breeding frogs and toads: turnover and synchrony. Ecological Applications 13:1522-1532.

Turner, R.E., A.M. Redmond, and J.B. Zedler. 2001. Count it up by acre or function mitigation adds up to net loss of wetlands. National Wetlands Newsletter 23:5-16.

Vannote, R.L., G.W. Minshall, K.W. Cummins, J.R. Sedell, and C.E. Cushing. 1980. The river continuum concept. Canadian Journal of Fisheries and Aquatic Sciences 37:130137.

Weakley, A.S., and M.P. Schafale. 1994. Non-alluvial wetlands of the Southern Blue Ridgediversity in a threatened ecosystem. Water, Air and Soil Pollution 77:359-383.

Weir, L., J.A. Royle, P. Nanjappa, and R.E. Jung. 2005. Modeling anuran detection and site occupancy on North American Amphibian Monitoring Program (NAAMP) routes in Maryland. Journal of Herpetology 39:627-639.

Yoccoz, N.G., J.D. Nichols, and T. Boulinier. 2001. Monitoring of biological diversity in space and time. Trends in Ecology and Evolution 16:446-453. 
Zedler, J.B. 1996. Ecological issues in wetland mitigation: an introduction to the forum. Ecological Applications 6:33-37.

Zimmerman, B.L. 1994. Audio strip transects. Pages 92-97 in W.R. Heyer, M.A. Donnelly, R.W. McDiarmid, L.C. Hayek, and M.S. Foster (Eds.). Measuring and monitoring biological diversity. Standard methods for amphibians. Smithsonian Institution, Washington, D.C., USA 